SUZANA PAPILE MACIEL CARVALHO

Estimativa do sexo em crânios da região de Guarulhos- SP utilizando antropologia física e DNA

São Paulo

2012 
SUZANA PAPILE MACIEL CARVALHO

Estudo estimativo do sexo em crânios da região de Guarulhos- SP utilizando antropologia física e DNA

\section{Versão Corrigida}

Tese apresentada à Faculdade de Odontologia da Universidade de São Paulo, para obter o título de Doutor, pelo Programa de Pós-Graduação em Ciências Odontológicas.

Área de Concentração: Odontologia Legal

Orientador: Prof. Dr. Rogério Nogueira de Oliveira

São Paulo 
Autorizo a reprodução e divulgação total ou parcial deste trabalho, por qualquer meio convencional ou eletrônico, para fins de estudo e pesquisa, desde que citada a fonte.

Catalogação da Publicação

Serviço de Documentação Odontológica

Faculdade de Odontologia da Universidade de São Paulo

Carvalho, Suzana Papile Maciel.

Estudo estimativo do sexo em crânios da região de Guarulhos -SP utilizando antropologia física e DNA / Suzana Papile Maciel Carvalho ; orientador Rogério Nogueira de Oliveira. -- São Paulo, 2012.

155 p. : fig., tab. ; $30 \mathrm{~cm}$.

Tese (Doutorado) -- Programa de Pós-Graduação em Ciências Odontológicas. Área de Concentração: Odontologia Legal. -- Faculdade de Odontologia da Universidade de São Paulo.

Versão corrigida.

1. Odontologia forense. 2. Antropologia física. 3. DNA. 4. Biologia molecular. I. Oliveira, Rogério Nogueira de. II. Título. 
Carvalho SPM. Estudo estimativo do sexo em crânios da região de Gusrulhos- SP utilizando antropologia física e DNA. Tese apresentada à Faculdade de Odontologia da Universidade de São Paulo para obtenção do título de Doutor em Ciências Odontológicas.

Aprovado em: / /2013

\section{Banca Examinadora}

$\operatorname{Prof}(\mathrm{a}) . \operatorname{Dr}(\mathrm{a})$. Instituição:

Julgamento: Assinatura:

Prof(a). Dr(a). Instituição:

Julgamento: Assinatura:

Prof(a). Dr(a). Instituição:

Julgamento: Assinatura:

$\operatorname{Prof}(\mathrm{a}) . \operatorname{Dr}(\mathrm{a})$. Instituição:

Julgamento: Assinatura:

Prof(a). Dr(a). Instituição:

Julgamento: Assinatura: 


\section{Dedico este trabalho primeiramente à Q Deus}

"senhor, quero dar-te graças de todo o coração e falar de todas as tuas maravilhas". Bỉblia Sagrada, Salmo 9:1.

Minha eterna gratidão à Ceus, minha fonte de vida, paz, alegria e amor!!! Meu grande amigo!

Meu Deus, sou eternamente grata a ti por tudo o que tem feito em minha vida!

Obrigada, Senhor, por sempre me acompanhar, em todos os momentos, ajudando-me a superar os desafios e a concretizar meus objetivos.

uSENHORoooé täo bom sonhar teus sonhoss

E täo bom viver teus planoss

E conhecer a grage de pertencer a Tis Deus Fiel!!

E tão bom fechar meus olhos e contemplar com minha fé todas as Tuas palauras

e Tuas promessas para mimp

E maravilhoso ver seu cuidado de Pai para comigo". 


\section{Dedico este trabalho aos meus pais, Qférgic e Diree (in memorian)}

Queridos pai e mãe, sou muito grata a Deus por ter me dado a oportunidade de ser muito amada por vocês! Ser gerada por pessoas tão nobres, tão amáveis, tão fortes é realmente um presente especial de Deus! Sou grata por serem meus mestres na vida, exemplos de dedicação, superação, integridade, honra, gentileza, alegria, inteligência e amor incondicional!

Obrigada por tudo o que fizeram por mim, por terem me apoiado, sempre com muito amor, em todos os momentos!

Obrigada por nunca medirem esforços em me ajudar a lutar pelos meus sonhos e a vencer os desafios da vida!

Devo todas as minhas conquistas a vocês!! E divido essa conquista com vocês!

Mầ, muito obrigada por toda a dedicação que sempre teve comigo! Obrigada por ter sido uma vovó tão amorosa, de cuja presença a Mamuela tanto sente saudade!! Frequentemente, ela olha no céu e vê sua estrela brilhar por ela! Obrigada por ter me incentivado e me ajudado a cursar o Doutorado!

Pai, você é um exemplo de homem sábio, íntegro, cheio de amor, sempre com um bom humor para lidar com as situações mais difícies! Sou grata a Deus por tudo o que você foi e continuará sendo em minha vida,

Oro a Deus para que eu seja para meus filhos pelo menos um pouco do que você foi e sempre será para mim!

Obrigada por ter me ensinado com muita simplicidade tudo o que uma pessoa precisa para viver e ser feliz!!!

$$
\text { OPai Mẫe, }
$$

Quero dizer-Ihes que valeu e continuará a valer muito!!

A presença de vocês estará para sempre na minha vida, aonde quer que eu vá, aonde quer que eu esteja.

Vocês estarão para sempre no meu coração e na minha mente. 
Dedico este trabalho a meu esposo, Raberto. Fernandes Garuatho Fimion

Obrigada por compartilhar comigo os momentos de vida pessoal e profissional!! Sou muito grata a Deus por tudo o que tenho aprendido nessa jornada juntos, pelos desafios, pelas alegrias, pelas tristezas, pelo amor e o maior fruto desse, o presente mais importante que ganhamos juntos, nossa filha Manuela, que é o motivo de nossa alegria e de nossa força por sempre melhorar! Divido essa conquista com você!

Roberto, Muito Obrigada por tudo!

Dedico este trabalho à minha filha, Manuela Maciel Gavealho

\section{"Os filhos são herança do Senhor, uma recompensa que Ele dá"}

(Bíblia Sagrada - Salmo 127: 3)

Minha amada filha, minha grande alegria, sou imensamente grata a Deus por ter me dado a oportunidade de gerar uma menina tão especial, doce, amável, feliz, cheia de vida! Você chegou na hora certa, preenchendo nossas vidas com sua alegria, com seu modo de ser! Seu sorriso, seu rostinho, seu abraço, seu beijo... é tão bom ouvir você me chamando de mamãe! Como é maravilhoso brincar, conversar, rir com você!

Obrigada por me ensinar a ser criança outra vez, a entender a beleza das coisas simples, a aprender a falar com os brinquedos, com os animais e com os amigos imaginários, a amar as pessoas como elas são, a aprender a sorrir até com os olhos... Obrigada por me mostrar a imensidão do amor, vivido com essa intensa emoção!!!

Você é um milagre de Deus!! Amo muito você!!! 
Dedico este trabalho às minhas irmãs

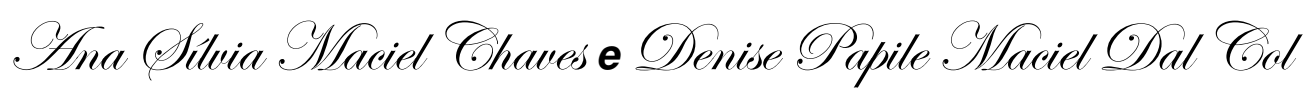

Minhas queridas irmãs, amigas, companheiras, vocês são muito importantes em minha vida e agradeço a Deus por tê-las ao meu lado! Obrigada por toda a ajuda, por torcerem por mim e por saberem rir e chorar comigo com muita sinceridade e amor! Amo vocês!

Dedico este trabalho aos meus sobrinhos Paulo Bruno. OPayane, Oitor, Queas Gavealho, Qfucas Maciel, Théo e ao meu afilhado, Claike

Vocês são muito importantes em minha vida pois sinto-me mãe e adoro compartilhar das suas vidas!

Vocês me ensinam muito, cada um com sua maneira de ser diferente, com suas alegrias e tristezas!

Amo-os muito mesmo!

Que vocês tenham muitas alegrias e muito sucesso! 


\title{
Agradecimentos Eespeciais
}

\author{
Aqueles que, quando deveriam ser professores, foram mestres, transmitindo-me seus \\ conhecimentos e experiências e que, quando deveriam ser mestres, foram amigos e, em sua \\ amizade me compreenderam e me incentivaram a seguir meu caminho, meus profundos \\ agradecimentos!!
}

Agradecimento especial ao Prof. Or. ORagério Ylogueiva de Oliveira Agradeço-lhe por ter me recebido como sua orientada neste curso de doutorado. Obrigada pela confiança depositada em mim! Sou grata pela compreensão, amizade e pelo carinho que demonstrou diante das dificuldades! Muito obrigada pelos ensinamentos transmitidos e pelas oportunidades que me deu!! Meu profundo respeito, minha amizade e meus maiores agradecimentos serão pouco diante do que me ofereceu!! Deus the abençoe!

\section{Agradecimento especial à Co-orientadora deste trabalho,}

OProf. Ore . Qucilene Brilho ORibeiro Bicudo

Obrigada pelo carinho com qual me acolheu quando pouco me conhecia e pela dedicação com que me conduziu! Obrigada pela paciência em ensinar algo novo para mim, e pela competência e dedicação demonstradas na conclusão desse trabalho!! Obrigada por não ter desistido de mim quando as dificuldades surgiram no trabalho! Nessa nossa convivência, com certeza, nasceu uma bonita amizade!!

Serei sempre grata a você por tudo o que fez por mim!

Deus Ihe abençoe muito! Muito obrigada!! 


\section{Agradecimentos}

"Durante todos esses anos várias pessoas colaboraram e me ensinaram muitas coisas... $E$ confesso que não aprendi tudo que queria, mas aprendi tudo que pude. Andei muito tentando alcançar este momento. E agora quero revelar meus sinceros agradecimentos às pessoas que me fizeram sorrir, chorar, sentir, viver... crescer..."

À Faculdade de Odontologia da Universidade de São Paulo, que me acolheu nesse doutorado.

Ao Centro de Estudo e Pesquisa em Ciências Forenses pela oportunidade de realização dessa pesquisa de doutorado, aos funcionários, especialmente a Josie, ao Wilson e ao aluno de pós-graduação, Fabricio, pela ajuda nesse trabalho. Agradeço especialmente ao Wilson pela extrema gentileza conosco sempre, pela amizade e pelo carinho! Wilson, você é uma pessoa rara e realmente especial! Muito obrigada por toda a ajuda sempre que precisei, sempre sem medir esforços e com muita paciência conosco! Muito Obrigada!

Ao Prof. Luiz Airton Saavedra de Paiva, pela parceria nesse trabalho, pela gentileza e pelo carinho para comigo! Professor, sua ajuda foi fundamental para que esse trabalho fosse realizado! Tenho-lhe muito respeito e admiração por seu empenho e dedicação ás pesquisas e aos alunos. Muito Obrigada!

Ao Hospital de Reabilitação de Anomalias Crânio- Faciais de Bauru, Centrinho, e ao Laboratório de Genética pela abertura para a realização das análises com DNA.

A todos os professores do Departamento de Odontologia Social da FO-USP, em especial àqueles com os quais me envolvi profissionalmente, Prof. Dr. Rogério Nogueira de Oliveira, Prof. Dr. Rodolfo Melani, Prof. Dr. Edgard Crosato, Prof. Dr. 
Edgard Michel- Crosato, Prof. Dra. Maria Gabriela Biazevic, pelos ensinamentos ministrados e pela atenção dedicada a mim.

Aos funcionários do Departamento de Odontologia Social da FO-USP, Sônia, Andréia e Maria Laura, pela contribuição em todos os momentos do doutorado.

A Bibliotecária Glauci Elaine, pelo carinho e pela ajuda na formatação da tese.

Aos colegas do doutorado, bem como aos demais colegas ingressantes nos outros programas, especialmente àqueles com quem mais convivi e que, de alguma maneira, colaboraram para a execução deste trabalho: Liz, Paulo, Tiago, Eliete, Francisco, Carol, Cris, Patrícia, Juliana, Teresa, André, Ricarda.

Especialmente a Liz Magalhães Brito, grande colaboradora deste trabalho, por quem tenho profundo carinho, respeito e amizade! Liz, sua participação foi fundamental e sou muito grata a você por ter se esforçado comigo para que esse trabalho fosse realizado! Obrigada por ter me acompanhado em Guarulhos, sendo uma excelente companhia! Agradeço a você e a Tati também por terem me recebido na casa de vocês com tanto carinho, num momento em que muito precisei! Obrigada por tudo, queridas!

Ao Laboratório de Genética do Centrinho pela recepção maravilhosa, na pessoa da minha co-orientadora e amiga, Lucilene Arilho Ribeiro Bicudo, a todos os funcionários, especialmente o Rubão, e alunos de pós e aos amigos que fiz ali, Rodrigo, Claudinha, todas as Anas, Letícia, Bruno, Quiara, Camila. E queria agradecer de modo muito especial ao Rodrigo e a Quiara por toda a ajuda nesse trabalho!

Aos amigos de trabalho, Fernanda, Ana, Karina, Eliete, Rafael, Angélica, Rafael Pinelli, Paola, Andresa, bem como suas famílias, minha gratidão pelos bons momentos que temos passamos juntos e pela parceria na vida profissional.

Ao Pr. Gilson, Shirlei e filhos, pelas orações, mensagens e pelo apoio espiritual a mim, ao Roberto, e à nossa filha Manuela, em todos os momentos. 
Aos amigos do grupo da Igreja Batista do Estoril, pessoas tão importantes em nossa vida e que muito têm nos ajudado: José Carlos, Alexandra, Gabi, Jünior.

Aos adolescentes da Igreja Batista do Estoril pela amizade, carinho e pela oportunidade de trabalharmos e crescermos juntos!

À Maria e Ana (especialmente) pelos cuidados de mãe e pelo carinho enorme dispensado à Manuela, bem como pelas inúmeras vezes que cuidaram dela para que eu pudesse executar esse trabalho! Sem vocês, teria sido muito difícil!

Aos pais do Roberto, Sr. Roberto e D.Marlene, muito obrigada pelo apreço com que me tratam, bem como por tudo o que fizeram por nós e pela Manuela.

Aos cunhados Sílvio, Renato, Joel e Fabiana, obrigada pela convivência muito agradável, pela ajuda e pela amizade!! Agradeço por fazermos parte da mesma família e sou grata por tudo o que fizeram por mim, pelo Roberto e pela Manuela!

Aos meus tios Inadir, Izabel e Julinho, Orlando, Bela, João, Rose, Paulo, Rubens e aos meus primos, agradeço todo o carinho, amor e atenção dispensados à nós.

Aos primos e grandes amigos Neto, Janice, Lu e Fábio, Kaike e Lucca, agradeço a intensa amizade, aos momentos que passamos juntos, às baladas, aos passeios, às viagens, enfim, vocês são muito importantes para nós!!

Aos primos e amigos Marcos, Solange, Maurício e Murilo, que nos receberam e nos ajudaram muito quando moramos em Piracicaba. Foi um período corrido, mas muito bom, tenho saudade de nossos churrascos, de nossas saídas e de nossas longas conversas... Muito obrigada pela ajuda e pelo carinho, espero poder, um dia, retribuir tudo o que fizeram por nós!

Aos grandes e verdadeiros amigos, presentes em todos os momentos, através de atos ou, ao menos, em palavras de conforto ou longas conversas, dividindo angústias e sonhos, alegrais e desesperos. Companheiros de baladas, jantares, 
churrascos, viagens... MUITO OBRIGADO: Kaula, Elbio, Carol, André, Letícia, Renato, Fernanda, Fábio, Larissa, Fernando, Marinez, Gabi, Andreza (in memoriam).

Aos sobrinhos "postiços", do coração, Pietra, Giulia, Rafaela, Lívia, Julia, Matheus ("filho postiço") agradeço por serem parte de minha vida e por me trazerem tanta alegria!! Amo vocês!!

A querida D. Cida por ter "adotado a mim como filha" e a Manu como neta, pelo carinho, dedicação e prontidão em sempre nos ajudar! A senhora é um exemplo de força e amor!

A todos os demais que de alguma forma contribuíram com o desenvolvimento deste trabalho e com a minha formação, meus mais sinceros agradecimentos. 


\section{RESUMO}

Carvalho SPM. Estudo estimativo do sexo em crânios da região de Guarulhos- SP utilizando Antropologia Física e DNA [tese]. São Paulo: Universidade de São Paulo, Faculdade de Odontologia; 2012. Versão Corrigida.

A investigação do sexo é uma das análises mais importantes na identificação humana. Este trabalho teve como objetivo a determinação do sexo em crânios humanos utilizando três métodos de Antropologica Física, duas quantitativas (Forensic Data Anthropolgy Bank, FDB, 1986 e Oliveira, 1995) e uma qualitativa, (Walker, 2008), e a análise genética pela amelogenina. A amostra foi composta de 66 crânios (34 homens e 32 mulheres) do Centro de Estudo e Pesquisa em Ciências Forenses, Guarulhos, SP. As metodologias foram aplicadas por duas pesquisadoras, que desconheciam o sexo dos crânios. Para o estudo estatístico realizaram-se análise descritiva, média, desvio padrão, análise discriminante linear e logística e regressão logística. A metodologia quantivativa apresentou um acerto de $89,52 \%$. O Método FBD teve uma acurácia de 92,31\%, com a elaboração de uma fórmula utilizando as medidas Largura Bizigomática, Altura Nasal, as quais apresentaram o maior dimorfismo entre os sexos, e Altura Básio-bregma e Máximo Comprimento do Crânio. A metodologia de Oliveira et al. (1995) necessitou de ajuste para a população estudada (nova fórmula com acurácia de 76,47\% em homens e 78,13\% em mulheres). Para o DNA, foi possível determinar o sexo em $86,15 \%$ da amostra. Pode-se afirmar que as diferentes metodologias comportaram-se de modo semelhante e com alta acurácia para determinação do sexo. A antropologia física apresenta as vantagens de facilidade de aplicação, reprodutibilidade e baixo custo, porém, necessita de ajustes populacionais. O DNA é mais complexo, necessita de infraestrutura e insumos específicos e pode ter interferência da condição ambiental, fatores que dificultam as análises, entretanto, não precisa ser ajustado á população.

Palavras-chave: Odontologia forense. Antropologia física. Antropologia forense. DNA. Biologia molecular. Caracteres sexuais. Diferenciação sexual. 


\begin{abstract}
Carvalho SPM. Estimative study of the sex in skulls from the region of Guarulhos SP using physical antropology and DNA [thesis]. São Paulo: Universidade de São Paulo, Faculdade de Odontologia; 2012. Versão Corrigida.
\end{abstract}

The investigation of the sex is one of the most important analyzes in the human identification. This study aimed to determine the sex in human skulls using three methodologies of Physical Anthropology, two quantitative (Forensic Data Anthropology Bank, FDB, 1986 e Oliveira, 1995) and one qualitative (Walker, 2008) and genetic analysis by amelogenin. The sample was composed by 66 skulls (34 men and 32 women) from the Center for Study and Research in Forensic Science, Guarulhos, SP. The methodologies were applied by two researchers who were unaware of the cranium's sexes. For the statistical analysis, there were performed descriptive analysis, average, standard deviation, linear discriminant analysis and logistic and logistic regression. The quantitative methodology presented an accuracy of $89.52 \%$. The FBD method had an accuracy of $92.31 \%$, with the development of a mathematical model using the measures Bizygomatic breadth, Nasal heigh, which showed the biggest dimorphism between the sexes, and Basion-bregma height and Maximum Cranial Length. The Oliveira's et al. (1995) methodology required adjustment for the studied population (new formula with an accuracy of $76.47 \%$ in men and $78.13 \%$ in women). For the DNA, it was possible to determine the sex in $86.15 \%$ of the sample. The different methodologies behaved similarly and with high accuracy in sex determination. Physical anthropology has the advantages of being easy to use, reliability and low cost, but needs population adjustments. The DNA is more complex, requires specific reagents and structure and may have interference from environmental condition, however, does not need to be adjusted to the population.

Keywords: Forensic Odontology. Physical Anthropology. DNA. Molecular Biology. Sex characteristics. Sex differentiation. 


\section{LISTA DE QUADROS}

Quadro 4.1 - Descrição dos elementos para análise somatoscópica dos crânios pelo Método de Walker (2008).

Quadro 4.2 - Sequência, concentrações e tamanho dos produtos das PCR do loci amelogenina .63

Quadro 4.3 - Reagentes utilizados nas reações de PCR 63

Quadro 4.4 - Ciclagem padrão utilizadas nas reações de PCR 64

Quadro 5.5 - Distribuição do elemento analisado em cada crânio (dente ou vértebra), estado apresentado, classificação do sexo segundo registro do

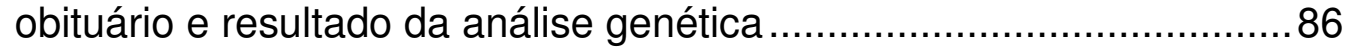




\section{LISTA DE TABELAS}

Tabela 5.1 - Distribuição das variáveis qualitativas segundo o indicador Kappa intraexaminador

Tabela 5.2- Distribuição das variáveis qualitativas segundo o indicador Kappa interexaminador.

Tabela 5.3- Distribuição das variáveis quantitativas $(\mathrm{N}=14)$ segundo o teste t para verificar a confiabilidade intraexaminador

Tabela 5.4- Distribuição das variáveis quantitativas $(\mathrm{N}=32)$ segundo 0 teste $t$ pareado para verificar a confiabilidade inter-examinador.

Tabela 5.5- Distribuição das variáveis qualitativas segundo categorias. 69

Tabela 5.6- Média e desvio padrão das variáveis qualitativas segundo categorias 69

Tabela 5.7- Resultado da análise discriminante aplicando a análise discriminante linear para a determinação do sexo utilizando várias combinações de variáveis independentes para as variáveis qualitativas. .70

Tabela 5.8- Resultado da análise discriminante utilizando a análise discriminante logística para a determinação do sexo utilizando várias combinações de variáveis independentes para as variáveis qualitativas. .71

Tabela 5.9- Equação da análise logística para a determinação do sexo utilizando diferentes combinações das variáveis independentes para as variáveis qualitativas 73

Tabela 5.10- Média, desvio padrão e intervalo de confiança das variáveis quantitativas segundo categorias. 
Tabela 5.11- Resultado da análise discriminante utilizando a análise discriminante linear para a determinação do sexo utilizando várias combinações de variáveis independentes para as medições

Tabela 5.12- Resultado da análise discriminante utilizando a análise discriminante logística para a determinação do sexo utilizando várias combinações de variáveis independentes.

Tabela 5.13- Equação da análise logística para a determinação do sexo utilizando diferentes combinações das variáveis quantitativas independentes para as medições

Tabela 5.14- Analise discriminante logística do Método Oliveira 83

Tabela 5.15- Regressão Logística do Método Oliveira 83

Tabela 5.16- Comparação dos resultados mais importantes para o sexo masculino 
2.1 ANTROPOLOGIA FORENSE E A IDENTIFICAÇÃO HUMANA .................. 22

2.2 ANTROPOLOGIA FORENSE E DIMORFISMO SEXUAL........................ 26

2.2.1 Análise qualitativa dos elementos do crânio para estimativa

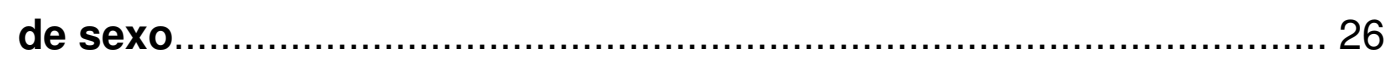

2.2.2 Análise quantitativa dos elementos do crânio para determinação

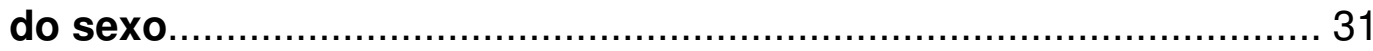

2.3 BIOLOGIA MOLECULAR E IDENTIFICAÇÃO HUMANA.......................... 37

2.3.1 Interferência dos fatores técnicos e ambientais na análise

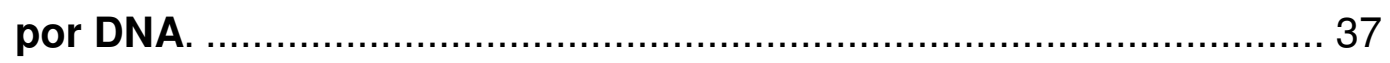

2.3.2 Biologia Molecular e dimorfismo sexual ............................................ 44

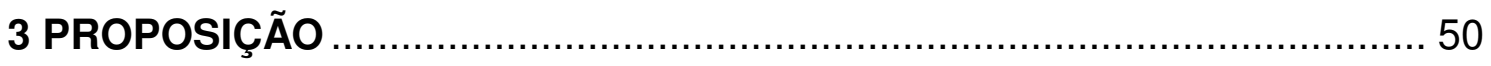

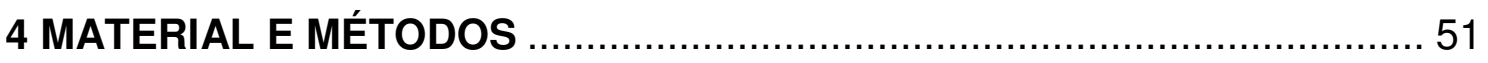

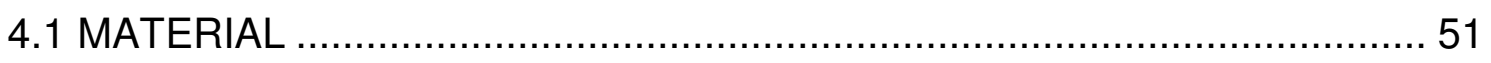

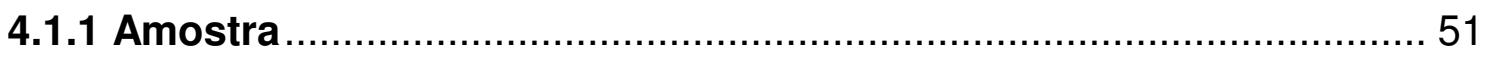

4.1.2 Materiais usados na Antropologia Física …………....................... 52

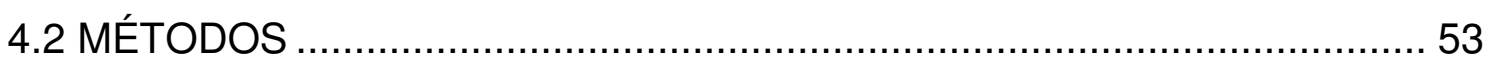

4.2.1 Atendimento às normas de bioética .............................................. 53

4.2.2 Calibração das pesquisadoras para análise antropológica

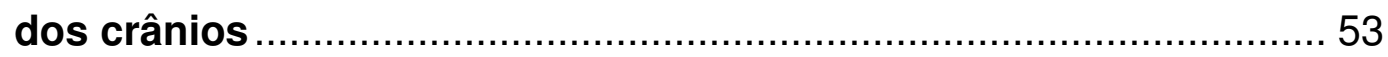

4.2.3 Análise e tabulação dos resultados................................................ 54

4.2.4 Análise antropológica: Metodologia de Walker............................... 54

4.2.4.1 Análise estatística da Metodologia de Walker .................................... 56

4.2.5 Método do Forensic Anthropology Data Bank (FDB) ...................... 56

4.2.5.1 Análise estatística do Método FDB …………................................. 58

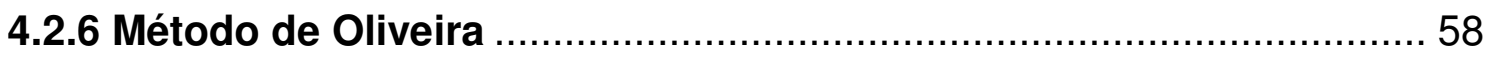

4.2.6.1 Análise estatística do Método Oliveira................................................ 59

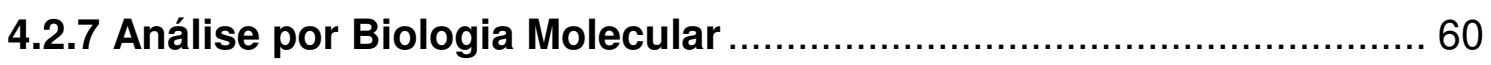


4.2.7.1 Análise das condições ambientais da região de coleta das amostras 60

4.2.7.2 Coleta dos dentes e das vértebras ...................................................60

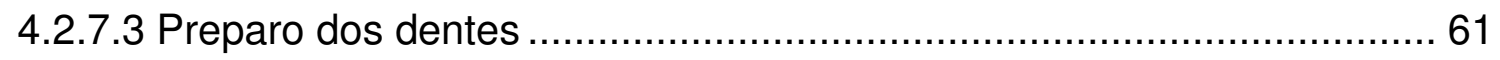

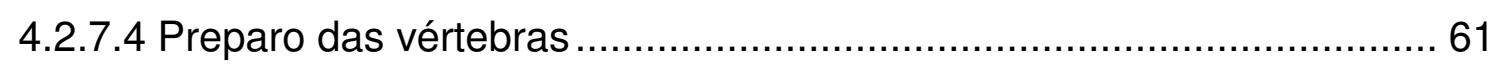

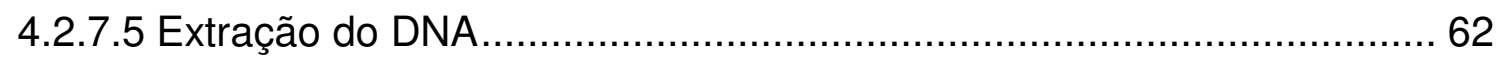

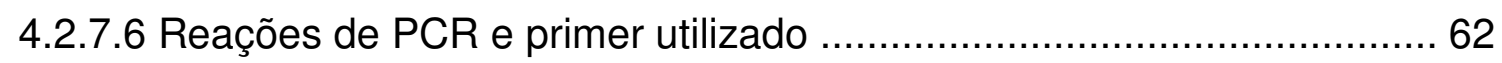

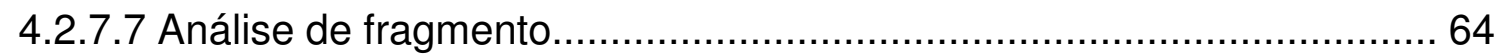

4.2.7.8 Análise estatística da metodologia que utiliza o DNA …...................... 64

5 RESULTADOS

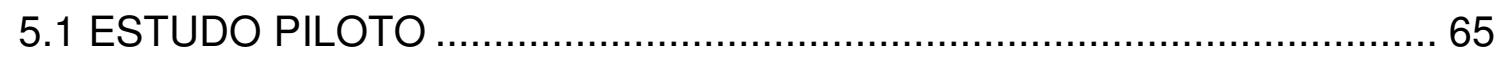

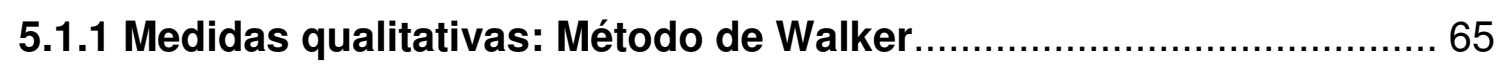

5.1.2 Medidas quantitativas: Métodos FDB e de Oliveira........................... 66

5.2 RESULTADOS DA ANÁLISE DO MÉTODO DE WALKER .......................... 68

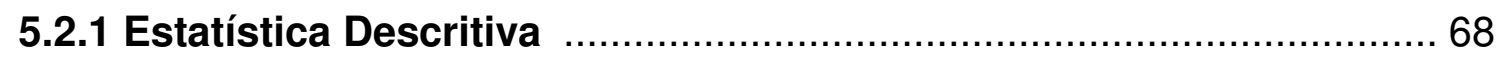

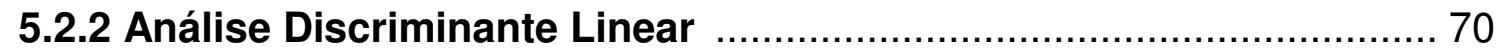

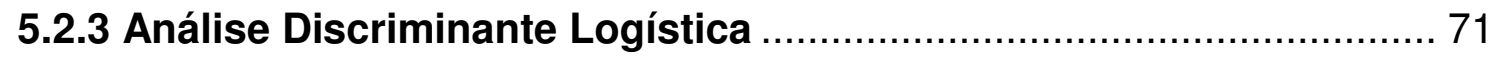

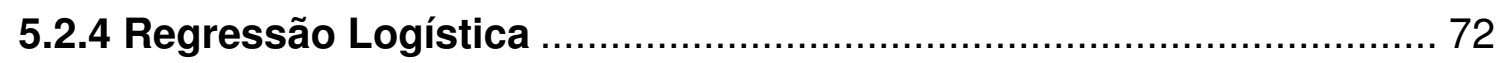

5.3 RESULTADOS DA ANÁLISE DO MÉTODO FDB.................................... 74

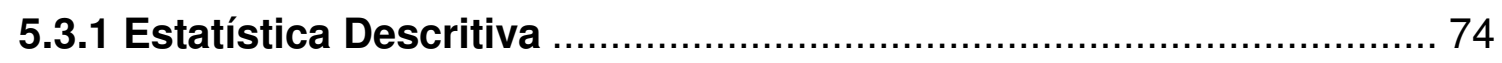

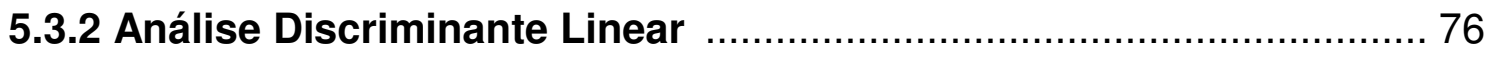

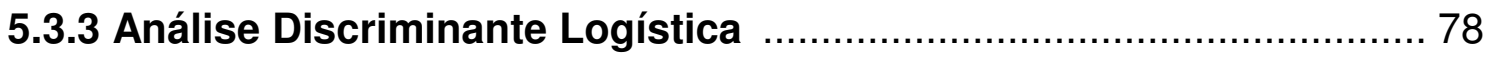

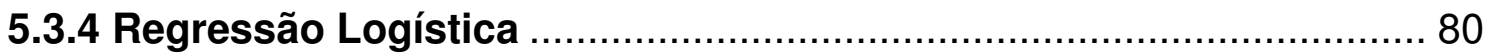

5.4 RESULTADOS DA ANÁLISE DO MÉTODO DE OLIVEIRA....................... 82

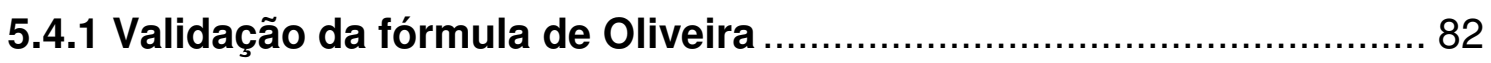

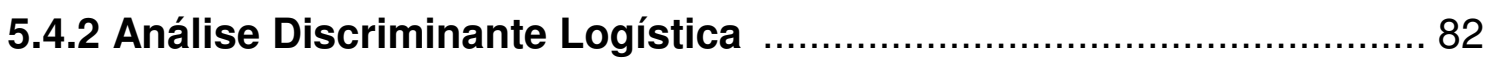

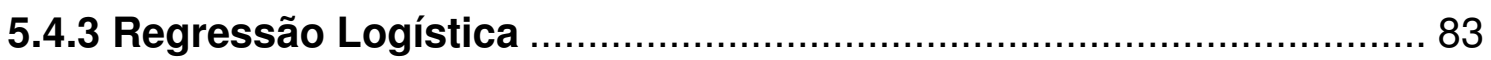

5.5 RESULTADOS DA ANÁLISE POR BIOLOGIA MOLECULAR …............... 83

5.5.1 Condições ambientais da região de coleta das amostras ................. 83

5.5.2 Resultado da Análise por DNA ………….................................... 84

5.6 COMPARAÇÃO DOS RESULTADOS MAIS IMPORTANTES …............... 87

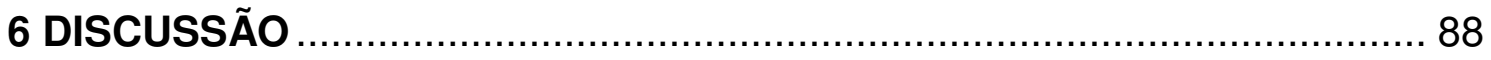

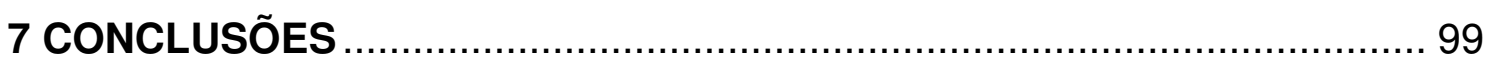

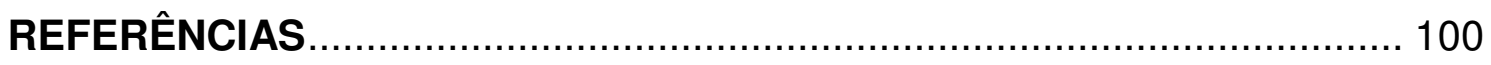

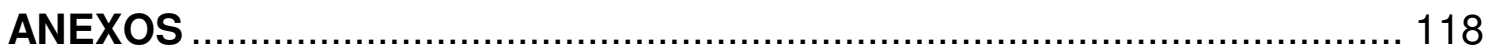




\section{INTRODUÇÃO}

A identificação humana é o processo pelo qual se procura determinar a identidade, ou seja, características individuais próprias pertencentes unicamente a uma pessoa. Essa diligência é imprescindível para resolver várias circunstâncias que envolvem o relacionamento social, devido as suas implicações éticas, penais e cíveis, e pode ser realizada no vivo, no cadáver e no esqueleto (Cattaneo et al., 2010).

Nesse ínterim, existem a identificação policial ou judiciária e a identificação médico-legal, na qual se insere a odontologia legal. E há uma infinidade de técnicas, com a participação de profissionais treinados e com conhecimentos específicos na área (Oliveira et al, 1998). Porém, recomenda-se que os métodos de identificação supram alguns requisitos, tais como, unicidade, imutabilidade, perenidade, praticabilidade, classificabilidade e reprodutibilidade (Daruge et al., 1975; Arbenz, 1988; França, 2007).

Nos casos de determinação da identidade humana, uma das principais características analisadas é o sexo. Tal investigação faz-se necessária quando envolvem indivíduos mortos, por permitir a redução no número total de sujeitos durante o processo de identificação do desconhecido (em situações de catástrofes, desastres em massa ou encontro de sítios arqueológicos), e nos casos in vivo, nas situações de intersexualidade, pseudo-hermafroditismo, estupro, investigação de maternidade/paternidade entre outros (Arbenz, 1988).

A Antropologia Forense consagrou-se pelas vantagens oferecidas por seus métodos, tais como a facilidade de aplicação, o baixo custo e a simplicidade dos equipamentos necessários para sua utilização. As metodologias antopológicas dividem-se em quantitativas e qualitativas, de acordo com os critérios utilizados para determinação do gênero. Assim, os métodos qualitativos baseiam-se na comparação visual de material ósseo de identificação desconhecida com protocolos de classificação baseados em material de identidade conhecida. Já a metodologia quantitativa faz uso de mensurações entre os pontos craniométricos conhecidos e definidos. Porém, as exigências de validação desses métodos fazem-se presente devido ás diferenças étnicas encontradas nos grupos populacionais, as quais têm 
relação direta com os aspectos fenotípicos e consequentemente, nos parâmetros antropológicos.

No caso do DNA, desde a descoberta de sua molécula, criou-se uma ideia mítica e, muitas vezes errônea, de infabilidade da prova do material genético, fazendo grassar a falsa expectativa de alcance quase infinito desta prova. Por um lado, o DNA é um método legítimo, eficaz e robusto, que não necessita de ajustes populacionais como os antropológicos, já que geneticamente o sexo é estabelecido independentemente da origem étnica do indivíduo. Por outro lado, a biologia molecular apresenta algumas dificuldades relacionadas á amostra e á complexidade técnica do método. A primeira refere-se ás peculiariedades encontradas no contexto forense, como a situação do vestígio biológico e o tratamento do mesmo para estudo e as condições ambientais envolvidas (temperatura, umidade, $\mathrm{pH}$ do solo, etc), os quais podem se constituir como fatores limitadores da análise do DNA. Já no contexto técnico, há a demanda de tempo e habilidade para a realização das análises e a necessidade de equipamentos e insumos específicos.

No Brasil, apesar de vários estudos de estimativa de sexo utilizando Antropologia Física já terem sido realizados (Lima, 1959; Daruge, 1965; Ferreira; Villi, 1968; Panella et al., 1992; Cardoso, 1993; Oliveira et al., 1995; Galvão, 1998; Camargo, 1999; Saliba, 1999; Sampaio, 1999; Almeida- Júnior et al., 2002; Ramalho et al., 2003; Valdrighi et al., 2003; Silva et al., 2005; Francesquini, 2007; Cornélio Neto, 2010; Almeida-Júnior; Galvão, 2010; Picapedra, 2010), muitas dessas metodologias foram testadas em apenas uma determinada região do país, sendo importante a extensão da validação das mesmas em vários estados, quando se considera o extenso território brasileiro e a miscigenação da população, graças à mistura entre os imigrantes europeus, africanos e asiáticos e a população indígena que já habitava o país (Zorzetto, 2007). Além disso, há estudos importantes para estimativa de sexo no meio científico, já aplicados em outros países e, que ainda não foram aplicados no Brasil, necessitando, então, de pesquisas locais para sua efetivação.

Nessa pesquisa, foram analisados a Antropologia Física e o DNA na determinação do sexo de esqueletos inumados há, pelo menos três anos, com o objetivo de avaliar a aplicabilidade dessas metodologias no contexto forense. $\mathrm{Na}$ Antropologia Física, aplicaram-se as metodologias quantitativas do FDB (Forensic Antropology Data Bank, 1986), ainda não usado no Brasil e a Metodologia de 
Oliveira et al. (1995), utilizada numa população de Salvador, Bahia. Já a Metodologia qualitativa escolhida foi a de Walker (2008). Para a determinaçào genética do sexo, analisou-se a amelogenina, comumente presente nos kits de identificação, chamados multiplex, contendo vários STRs. Para isso, foram estudados os dentes extraídos dos esqueletos exumados e, no caso de desdentados, retiraram-se as vértebras (tecido ósseo) dos mesmos.

Inicialmente, analisaram-se os resultados obtidos nos métodos antropológicos métricos e na metodologia visual, bem como a validação dos mesmos na população estudada. Em seguida, foram consideradas as condições da amostra e do ambiente envolvido na recuperação do DNA, comparando-se os resultados obtidos na antropologia com a genética. 


\section{REVISÃO DA LITERATURA}

\subsection{ANTROPOLOGIA FORENSE E A IDENTIFICAÇÃO HUMANA}

A Antropologia surgiu em Atenas, três séculos antes de Cristo, com Aristóteles, o qual classificava os antropólogos como os filósofos que dissertavam sobre a natureza do homem. Os estudos da Antropologia Física propriamente iniciaram-se com Galeno, no século segundo. O vocábulo antropologia surgiu somente em 1501, quando Magnus Hundt publicou o livro assim intitulado (Silva, 1997). Posteriormente, surgiram estudiosos que aperfeiçoaram os estudos anatômicos do homem, como Vesalius, Buffon, Eustáquio, Spiegel, Lineu, Cuvier, Lamark, Darwin e outros (Avila, 1958; Silva, 1997; Vanrell, 2009).

No século XIX, houve um grande crescimento da Antropologia Física, com as primeiras publicações científicas, aliadas a aplicação prática de princípios antropológicos em processos de identificação humana. Nesse momento histórico, ocorreu o primeiro caso de identificação odontolegal, em 1897, Paris, mais precisamente no Bazar da Caridade, local onde a burguesia estava reunida em torno de leilões beneméritos. Houve um incêndio com quase 200 mortos, dos quais 40 restaram sem identificação, dentre eles a Duqueza de D'Aleman e a Condessa Villeneuve. Por sugestão do cônsul do Paraguai Dr. Albert Hans, os cirurgiõesdentistas daquelas personalidades, coordenados por Oscar Amoedo, foram chamados para identificar, através dos restos carbonizados, seus supostos pacientes, o que tornou possível a identificação das citadas pessoas dentre outras que também pereceram na tragédia (Radicchi, 2006).

Em seguida, outros casos históricos envolvendo Antropologia Física e Odontologia ocorreram, como por exemplo, o incêndio da Legação Alemã, no Chile (1909), o Titanic (1912), os casos dos soldados da Segunda Guerra (década de 1940), e, notadamente, no Brasil, o caso da identificação de Josef Mengele (1987) (Avila, 1958; Silva, 1997). Desde então, a Antropologia Forense não parou mais de se desenvolver, sendo determinante nas situações em que há a necessidade da identificação de indivíduos. 
A Antropologia Forense é a aplicação prática ao Direito de um conjunto de conhecimentos da Antropologia Geral visando, principalmente, a questões relativas à identidade médico-legal e à identidade judiciária ou policial (Croce; Croce-Junior, 2004). E a identificação humana é uma das grandes áreas de estudo e pesquisa da Odontologia Legal e da Medicina Legal. Assim, as duas ciências trabalham com o mesmo material, o corpo humano, em vida e em vários estados do pós-mortem (espostejados, dilacerados, carbonizados, macerados, putrefeitos, em esqueletização e esqueletizados), sempre com o mesmo objetivo, ou seja, estabelecer a identidade humana (Oliveira et al., 1998).

Estudos mostram que, nos últimos 30 anos, houve um crescimento expressivo da antropologia forense no mundo todo, tanto pela aplicação nos casos médico legais, como pela quantidade de pesquisas (Íscan; Olivera, 2000; Cattaneo, 2007; Cattaneo et al., 2010). O Crescimento da área foi registrado para muitos países, incluindo China, Hong Kong, Hungria, Japão, África do Sul, Turquia, Alemanha, Índia, Dinamarca, Egito, Polônia, Espanha, Reino Unido e EUA (Íscan, 2001).

E nesse contexto, o número de cientistas trabalhando no campo forense e da antropologia e o grau de cooperação internacional entre os vários grupos estão aumentando. Há tentativas internacionais de normalização da qualidade das técnicas e metodologias aplicadas nos diferentes países, com a utilização de métodos melhores e mais eficientes, como exemplos, o DVI (Disaster Victim Identification Guide - Interpol) e a criação de bancos de dados forenses, como o Forensic Data Bank (http://fac.utk.edu/databank.html) e o de Howells (kttp://konig.la.utk.edu/hoells.htm) (Íscan; Olivera, 2000; Brinkmann, 2007; Cattaneo, 2007; Dirkmaat et al., 2008; Konigsberg et al., 2009).

Nesse ínterim, padrões antropológicos têm sido desenvolvidos para aplicação em populações de regiões diferentes do mundo com o objetivo de contribuir na identificação humana. Tais estudos procuram estabelecer protocolos para estimativa de sexo, idade, estatura, grupo étnico, fatores de individualização, superposição de imagens, reconstrução facial e análise por DNA (Íscan; Olivera, 2000; Cattaneo, 2007).

O desenvolvimento regional da Antropologia, com pesquisas nos diferentes grupos populacionais é extremamente importante, especialmente nos casos nos quais a variação da população pode causar problemas na identificação de um 
indivíduo nativo com a aplicação de padrões desenvolvidos para comunidades distintas (Íscan; Olivera, 2000; Íscan, 2001; Brinkmann, 2007; Cattaneo, 2007; Dirkmaat et al., 2008).

Existem dois tipos de processos de identificação humana: o comparativo e o reconstrutivo. O primeiro é baseado na comparação de registros anteriores ao óbito, permitindo a identificação personalista ou individual, possível de ser realizada através da utilização de registros médicos e prontuários odontológicos. Já no processo reconstrutivo, não se têm dados anteriores à morte do indivíduo e procurase realizar a identificação geral definindo-se, por exemplo, o gênero, a idade e a etnia (Sassouni, 1963). Na identificação geral incluem-se o diagnóstico de manchas ou líquidos provenientes da cavidade bucal, ou nela contidos e a definição da causa e do tempo de morte (Oliveira et al.,1998).

Sweet (2001) afirmou que existem três tipos de identificação nas quais se utilizam caracteres bucais, maxilares e características orofaciais, sendo que dois deles têm sido usados por muitas décadas e configuram-se como responsabilidade primária do odontolegista. O primeiro é denominado de identificação dentária comparativa e envolve a comparação dos registros ante-mortem e post-mortem, através de prontuários, fotos, radiografias, etc. $O$ segundo, composto pela reconstrução do perfil dentário post-mortem, é usado em casos onde não há suspeita de quem pode ser a pessoa ou seus descendentes; e, o terceiro trabalha na aplicação das modernas técnicas de perfil de DNA a fim de se estabelecer a identidade.

A atuação do cirurgião-dentista no âmbito forense é assegurada pela legislação federal competente, a Lei $n^{\circ} 5.081$, de 24 de Agosto de 1966, que regulamenta o exercício da odontologia no Brasil. Além disso, a Resolução CFO $63 / 2005$ regulamenta, através de seu artigo 28 , as áreas de atuação do profissional especialista em Odontologia Legal (Brasil, 2012):

Art. 28. As áreas de competência para atuação do especialista em Odontologia Legal incluem:

a) Identificação humana;

b) Perícia em foro civil, criminal e trabalhista;

c) Perícia em área administrativa; 
d) Perícia, avaliação e planejamento em infortunística;

e) Tanatologia forense;

f) Elaboração de: 1) autos, laudos e pareceres; 2) relatórios e atestados;

g) Traumatologia odonto-legal;

h) Balística forense;

i) Perícia logística no vivo, no morto, íntegro ou em suas partes em fragmentos;

j) Perícia em vestígios correlatos, inclusive de manchas ou líquidos oriundos da cavidade bucal ou nela presentes;

l) Exames por imagem para fins periciais;

m) Deontologia odontológica;

n) Orientação odonto-legal para o exercício profissional;

o) Exames por imagens para fins odonto- legais.

A mídia tem colocado em evidência a participação da Odontologia Legal no contexto forense, nos casos dos processos de identificação de cadáveres decorrentes de acidentes de massa como desastres naturais, tais quais os tsunâmis ocorridos em 2004 (Lau et al., 2005; Morgan et al., 2006; Rai, 2007), as enchentes e chuvas (Medina et al., 2010), os acidentes de ônibus seguidos de carbonização das vítimas (Valenzuela et al., 2000; Valenzuela et al., 2002), os acidentes aéreos (Ferreira, 1996; Nambiar et al., 1997), os incêndios (Campobasso et al., 2003) e acidentes militares e guerras (Brannon; Morlang, 2004; Marjanovíc et al., 2007; Slauss et al., 2007).

Reforçando a importância da Antropologia Forense e da Odontologia legal, pode-se citar o trabalho feito por Cattaneo et al., 2010. No intuito de avaliar os métodos de identificação humana mais comumente utilizados na prática diárias dos institutos médico legais, foi realizado um extenso estudo retrospectivo em Milão, o qual analisou como foi feita a identificação de cadáveres em um período de 14 anos (1995- 2008), em um total de 14.607 necropsias. Os resultados mostraram que a maioria desses processos envolveu odontologia (23\%) e antropologia forense (23\%).

Isso evidencia a relevância da odontologia na descoberta da identidade humana e aponta para a necessidade de mais pesquisas na área, principalmente no Brasil. 


\subsection{ANTROPOLOGIA FORENSE E DIMORFISMO SEXUAL}

Os ossos humanos apresentam caracteres dicotômicos sexuais, tanto qualitativos como quantitativos, possibilitando, o esqueleto completo, um diagnóstico diferencial em $94 \%$ dos casos. E, entre os ossos com maiores variações entre os gêneros, encontra-se o crânio, o qual pode diferenciar o sexo, segundo trabalhos, num intervalo entre $77 \%$ e 92\% dos casos (Arbenz, 1988; Almeida; Costa, 1981; Galvão, 1998; França, 2007).

O diagnóstico do sexo pelo crânio pode ser realizado por critérios baseados na comparação visual dos ossos questionados pelos correspondentes de origem conhecida, o método qualitativo ou através de mensurações aplicadas nos elementos cranianos, a metodologia quantitativa.

\subsubsection{Análise qualitativa dos elementos do crânio para estimativa de sexo}

Com relação ao aspecto qualitativo, normalmente os crânios masculinos possuem as estruturas mais grosseiras ou ásperas devido às inserções musculares serem mais fortes. Desse modo, esses crânios apresentam maior angulosidade, tamanho, peso, capacidade craniana (em média $150 \mathrm{~cm}^{3}$ a mais do que no crânio feminino), espessura dos ossos, maior alongamento, com valores mais baixos no índice comprimento- largura, impressões musculares mais fortemente modeladas, especialmente as da região nucal, com a crista occipital externa mais desenvolvida. As linhas temporais são bem mais marcadas e as cristas supramastóideas mais destacadas (Pereira; Alvin, 1978; Ramirez, 1990; França, 2007).

Então, nos crânios masculinos, os arcos superciliares são mais desenvolvidos, as bordas supraorbitárias espessas e não cortantes, as órbitas mais baixas, a região da glabela é mais proeminente e grosseira, o frontal é menos acentuado, enquanto o parietal apresenta-se mais acentuado, ou seja, pela norma anterior, há uma dominância parietal, sendo o crânio feminino predominantemente frontal. Além disso, nos elementos masculinos, as apófises estilóides são mais robustas e as mastóides mais desenvolvidas, a cavidade occipital é maior e os 
côndilos do occipital são mais desenvolvidos, com a superfície da base do crânio mais rugosa. Também os arcos zigomáticos são mais espessos nos homens, os dentes são comumente maiores, a mandíbula mais maciça e mais robusta, e as apófises angulares e os côndilos mandibulares mais volumosos (Pereira; Alvin, 1978; Coma, 1991; Carvalho et al., 1992; França, 2007; Madeira, 2010).

Peixoto (1918) examinou cadáveres putrefeitos e esqueletizados, destacando que a identificação antropológica pode ser realizada considerando-se as características dimórficas que o crânio apresenta. Para o sexo masculino foram evidenciados crânios e mandíbulas mais pesados, rugosos, volumosos, bossas e diâmetros mais acentuados, todavia o inverso foi encontrado para o sexo feminino.

Abreu (1929) descreveu, em seu livro, que no sexo feminino, os seios frontais, os arcos superciliares e a glabela são menos acentuados e salientes, o crânio é menor e mais arredondado, e a mandíbula é mais delicada, mais leve, com ângulos mais arredondados e disfarçados. Ressalvou, porém que esses dados não fornecem elementos seguros para diagnóstico diferencial do sexo, apresentando pelo menos $5 \%$ de erro e $20 \%$ de resultados duvidosos, ou seja, embora essas diferenças estejam presentes na maioria dos crânios, esse dado não é absoluto, de modo que há poucos indivíduos nos quais é praticamente impossível a diagnose sexual.

Em sua $6^{\underline{a}}$ edição do "Tratado de Medicina-Legal", Souza-Lima (1938) reportou que no sexo feminino tanto as margens da maxila (margem supraorbital e lacrimal), como da mandíbula, são mais elípticas, os dentes são menores e mais semelhantes e a cavidade oral mais curta e mais estreita.

Keen (1950) estudou as diferenças entre os crânios masculino e feminino, em uma amostra conhecida de 50 indivíduos de cada sexo, todos adultos. Foram coletadas, entre mensurações e índices, 23 parâmetros. Dos critérios anatômicos listados, três apresentaram valores presumivelmente aplicáveis a todos os grupos raciais: os arcos superciliares, a crista occipital externa e a crista da margem superior do meato acústico externo, todos classificados visualmente em diferentes categorias, de traço nulo a excessivo. $O$ autor defendeu que uma inspeção nesses elementos é suficiente para se decidir se o crânio é masculino, feminino ou se não pode ser classificado em um grupo definido.

Lima (1959) constatou que o dimorfismo sexual do esqueleto é inexpressivo na infância, pois se inicia na puberdade e torna-se mais evidente depois dos vinte 
anos. O mais comum foi encontrar na infância e velhice caracteres bem semelhantes aos do sexo feminino nos crânios estudados. $O$ autor classificou ainda as diferenças sexuais do crânio e face em dois grupos: caracteres qualitativos e quantitativos, fazendo a seguinte crítica: embora numerosos e importantes, dão origem a muitos erros. Quanto aos caracteres qualitativos, no sexo feminino, as estruturas eram menores e mais delicadas, sendo que o masculino ocorreu o antônimo.

Teixeira (1978) afirmou que após puberdade, o organismo entra na fase adulta, próximo dos 20 anos, sendo esta a melhor fase para diagnosticar o sexo pelo exame da pélvis, crânio, esterno e ossos longos. Em sua pesquisa, foram relacionados os principais caracteres que determinam o sexo masculino pelo segmento cefálico, ou seja, eminências supraorbitárias mais evidentes e rombas, ângulo nasal fechado, apófises mastóides maiores e rugosas, sendo ponto de apoio do crânio em plano horizontal e mandíbula mais angulosa. Para o sexo feminino a eminência supraorbitária apresenta-se menos saliente e cortante, ângulo frontonasal curvilíneo, apófises mastóideas mais delicadas e mandíbula mais curva. Destacou ainda que o crânio do homem é maior do que o da mulher.

Bennett (1981) afirmou que nos homens o palato se apresenta largo, em forma de $U$, dentes grandes e molar inferior com 5 cúspides e mandíbula grande com ângulo próximo ao reto, entretanto nas mulheres o palato é pequeno e mais parabólico, molar inferior com 4 cúspides e a mandíbula apresenta dimensões menores. No homem, a fossa canina é mais profunda e na mulher pouco visível. Os dentes nas mulheres são menores e mais altos que largos. Os incisivos têm posição perpendicular nos homens e posição mais oblíqua nas mulheres.

Coma (1991) considerou que nos casos em que se têm fragmentos ou remanescentes carbonizados, alterados pela ação do tempo ou terreno, a determinação do sexo fica cada vez mais difícil. $O$ autor afirmou que a diferenciação sexual não é a mesma entre as cores de pele e nenhuma característica pode ser considerada absoluta. O diagnóstico do sexo por meio do crânio deve ser feito em comparação a uma série de outros do mesmo grupo a fim de conhecer os padrões daquele grupo. Os traços podem estar atenuados pela idade, ou seja, os crânios pertencentes a jovens ou a idosos podem se assemelhar aos femininos. $O$ autor listou aspectos morfológicos que diferenciam os crânios femininos e masculinos. Afirmou, ainda, que os caracteres masculinos e femininos se mesclam e poucos crânios são extremamente femininos ou muito masculinos. Finalizou afirmando que 
as estruturas dentais têm maior dimensão nos sexo masculino, sendo que o canino é o que apresenta maior dimorfismo.

Utilizando-se de medidas qualitativas para estimativa de sexo, Konisberg e Hens (1998) realizaram uma pesquisa em 138 crânios no Mississipi. Foram utilizados seis indicadores: forma do arco superciliar, forma do queixo, tamanho do processo mastóide, padrão da margem supraorbitária e crista nasal. A regressão logística classificou corretamente 66 dos 74 crânios masculinos e 46 dos 64 femininos, com um acerto de $81 \%$, mostrando que parâmetros visuais aplicados em crânios podem ser usados na estimativa de gênero.

Celbis et al. (2001) realizaram um estudo numa amostra composta de 90 crânios de sexo e raça conhecidos (todos caucasóides), obtidos do Conselho de Medicina Forense em Instambul - Turquia, com o objetivo de associar as diferenças na região da glabela com o dimorfismo de sexo. O grau de suavidade-rugosidade da glabela foi classificado em quatro tipos: 0 = muito suave; 1 = suave; 2 = rugoso; 3 = muito rugoso. Os resultados demonstraram que nenhum homem foi classificado como tipo 0 , bem como nenhuma mulher como tipo 3. Os indivíduos masculinos foram classificados mais no tipo 1 ou acima e os femininos foram classificadas mais no tipo 1 ou abaixo. Os autores concluíram que existe dimorfismo de sexo na região supranasal e acreditam que seja resultado da ação dos músculos da expressão facial e função mastigatória.

Rogers (2005) avaliou, em 46 crânios, a acurácia e a precisão de 17 características morfológicas comumente usadas para identificar o sexo de esqueletos desconhecidos. Uma combinação das três características, extensão e tamanho do zigomático e abertura nasal forneceu o melhor resultado, com acurácia de 91\%. Aplicando-se as 17 avaliações, chegou-se a um acerto de 89,1\%. Esse estudo mostrou que a combinação das características morfológicas do crânio pode ser aplicada para o dimorfismo sexual.

Williams e Rogers (2006) realizaram um estudo em 50 crânios de europeus brancos com o objetivo de avaliar a precisão e exatidão de 21 características morfológicas. Quando todas as características foram avaliadas conjuntamente, os autores encontraram $96 \%$ de precisão. Os pesquisadores concluíram também que o tamanho do mastóide, o tamanho da crista supraorbital, a rugosidade do zigomático, o tamanho e forma da abertura nasal e o ângulo goníaco são identificados com altos traços de qualidade, enquanto a sínfise do ramo da mandíbula, a extensão do 
zigomático, e as marcações do occipital, demonstraram maior tendência a ser masculinos que femininos.

$\mathrm{Hu}$ et al. (2006) classificaram a mandíbula como o mais largo e mais compacto osso da face e, por isso, um dos melhores ossos para utilização na antropologia física, com aplicação na distinção de grupos étnicos e de sexo. Assim, examinaram 13 características morfológicas de 102 mandíbulas de coreanos de ambos os sexos. Dessas, a melhor característica para distinção de sexo foi o contorno da margem inferior mandibular. Nos homens, a mandíbula exibiu um padrão mais acidentado, enquanto que nas mulheres, mais retilíneo. Além disso, a região do mento foi bem diferente entre os sexos: o formato do queixo masculino era mais quadrado, enquanto que no sexo feminino, apareceu mais pontiagudo. Nesse estudo, o grau de acerto foi de 92,5\% para homens e 73,7\% para mulheres, mostrando que o método não métrico pode ser utilizado para distinção de sexo pela mandíbula.

Posteriormente, Walker (2008) testou a acurácia na determinação do sexo por características visuais classificando as estruturas: protuberância mentual, margem supraorbital, margem supraorbital/glabela, crista occipital externa e processo mastóide, em 304 crânios nas populações: américa-européia, américa-africana, ancestrais ingleses e uma amostra de 156 indivíduos americanos nativos, cuja determinação do sexo havia sido feita pela pélvis. A estatística por regressão logística mostrou que o método classificou corretamente em $88 \%$ para as cinco características e em $78 \%$ na comparação com a pélvis, resultados similares aos alcançados com análise quantitativa. Os autores apontaram a facilidade de aplicação da metodologia visual no contexto forense, apenas pontuando a subjetividade como uma desvantagem nesse tipo de estudo.

Galdames et al. (2008) realizaram um estudo em 284 crânios de brasileiros adultos, sendo 187 do sexo masculino e 97 do sexo feminino. Os autores fizeram uma análise qualitativa em 16 traços usados tradicionalmente para verificação do dimorfismo de sexo. Observaram que a apófise mastóide, osso zigomático, mandíbula e rugosidade do osso occipital são os melhores indicadores do dimorfismo sexual pela morfologia do crânio. 


\subsubsection{Análise quantitativa dos elementos do crânio para determinação do sexo}

Giles e Elliot (1963), ao discorrerem sobre os trabalhos já realizados para se determinar o sexo humano pelo crânio, através de observações morfológicas e/ou diferenças métricas, concluíram que em todos os estudos existe uma grande possibilidade percentual de estimar-se corretamente o sexo através do crânio. Eles utilizaram 408 crânios, sendo 187 de indivíduos brancos (108 masculinos e 79 femininos) e 221 de indivíduos negros (113 masculinos e 108 femininos); em todos os grupos, as idades estavam compreendidas entre 21 e 75 anos. Foram realizadas 11 mensurações em cada um dos 408 crânios, mas somente 9 medidas foram utilizadas nas 21 funções discriminantes para determinação do sexo. Os resultados de acurácia, obtidos entre 82 a $89 \%$, para ambos os grupos raciais, sugeriram que a diferenciação sexual realizada independe da variação racial, podendo o método ser empregado para outros grupos raciais, como irlandeses e índios americanos, com resultados satisfatórios.

Para determinar o sexo por análises de funções discriminantes da mandíbula humana, Giles (1964) utilizou-se de 265 peças ósseas pertencentes a indivíduos negros e brancos, conseguindo acurácia aproximada de $85 \%$. Foram realizadas 9 mensurações: altura da sínfise da mandibula, diâmetro bigoníaco, altura e larguras mínima e máxima do ramo da mandíbula, altura, espessura e comprimento do corpo da mandíbula e largura bicondilar. Em seguida, foram empregadas nove funções diferentes, sendo que para cada grupo racial (branco, negro e associação de brancos e negros) foram realizadas três funções diferentes, utilizando três, cinco e seis mensurações. Pelos resultados das análises, o autor concluiu ser o dimorfismo sexual da mandíbula humana de maior valor do que as diferenças raciais, possibilitando a estimativa o sexo de remanescentes ósseos humanos de diferentes populações.

Kajanoja (1966) estimou o sexo em uma amostra de 232 crânios de finlandeses, utilizando 8 mensurações e desenvolvendo 2 funções discriminantes para esse grupo racial específico, com $80 \%$ de classificações corretas. Testou, ainda, a aplicabilidade das funções discriminantes desenvolvidas por Giles e Elliot (1963), para crânios humanos de brancos e negros americanos, encontrando, em sua amostra, uma acurácia de $65 \%$.

Em 1986, Uytterschaut realizou uma pesquisa comparando três diferentes populações através da aplicação de funções discriminantes de sexo. Foram 
realizadas 18 medidas baseadas na metodologia de Howells (1973), aplicadas nas amostras de crânios de Amsterdam (europeus), África (negróides) e Japão (mongolóides). Os resultados obtidos indicaram que, embora ainda não se possa afirmar que as funções utilizadas nesse estudo possam ser válidas em qualquer população, mostrou ser eficiente nos três grupos testados (80\% de acerto), sugerindo uma possível aplicação positiva em outras civilizações.

Johnson et al. (1989) aplicaram medidas para determinação de sexo e raça. Os autores sugeriram que as mensurações utilizadas para a melhor discriminação do grupo racial não são necessariamente as melhores mensurações para diferenciar o dimorfismo sexual nos diferentes grupos raciais. As melhores medidas para determinação de sexo coincidentes nos grupos foram comprimento glabela opistocrânio, largura nasal e altura subnasal.

Oliveira et al. (1995), estudando mandíbulas e relacionando-as com a estimativa de sexo, desenvolveram metodologia específica para padrões nacionais, na qual as características consideradas foram: a altura do ramo da mandíbula e a distância bigoníaca, sendo os valores analisados estatisticamente. Através de regressão logística e análise de função discriminante, verificou-se uma boa margem de acerto de, respectivamente, 77,7\% e 78,33\%. Ao final, os autores desenvolveram um software para utilização em padrões métricos de indivíduos brasileiros adultos.

Valdrighi et al. (2003) realizaram um trabalho com o objetivo de estudar as características diferenciais entre 200 crânios pertencentes a indivíduos de ambos os sexos usando as medidas: bizigomática, próstio-glabela, próstio-espinha nasal anterior e bi-temporal. Os resultados foram submetidos à análise estatística por regressão logística, estabelecendo-se uma fórmula para determinação do sexo ( $X=30,4480$ - 0,2461 bi-zigomática), com um índice de confiança de 82,2\%. Os autores concluíram que é um método eficiente, que pode ser implementado em serviços de antropologia e institutos médico-legais com alta margem de segurança.

Dentre as estruturas cranianas comumente usadas na diagnose sexual, encontra-se o processo mastóide, o qual se apresenta bem mais robusto nos homens. Alguns estudos já puderam comprovar esta diferença, como o de Hoshi (1962), Whall e Henke (1980), Paiva e Segre (2003), Kemkes e Gobel (2006). Paiva e Segre (2003) analisaram 60 esqueletos, 30 de cada sexo. Foi obtido um xérox de cada crânio e os pontos craniométricos foram marcados, demarcando um triângulo, cuja área foi obtida. Os resultados indicaram que, nos crânios masculinos, essa área 
apresentava-se maior, possibilitando a criação de uma tabela com intervalo de confiança com valores máximo e mínimo referentes a ambos os sexos.

Com o objetivo de examinar o dimorfismo sexual em indígenas, no sul da África e produzir uma função discriminante para isso, Franklin et al. (2005) examinaram 332 crânios (182 masculinos e 150 femininos). Eles aplicaram oito medidas de Giles e Elliot (1963), sendo que algumas são comuns ao método de Howells (1973), e fizeram análise tridimensional, produzindo algumas funções discriminantes. Os resultados confirmaram as maiores dimensões no sexo masculino. Conseguiram uma acurácia de 77 a $80 \%$, valores parecidos com os obtidos pelos autores da metodologia, indicando que essas mensurações podem ser usadas nessa população para discriminação de sexo.

Para investigar se a mandíbula pode contribuir na discriminação do sexo de indivíduos sub-adultos, os autores Franklin et al. (2007) aplicaram a técnica de morfometria geométrica. A amostra foi composta de 96 mandíbulas de subadultos de três populações, a africana-americana, a sul-africana e a caucasiana. As coordenadas em três dimensões em 38 pontos da mandíbula foram analisadas pelo softawre morphologika. Regressões multivariadas indicaram não ter dimorfismo sexual significante na população subadulta estudada, resultado suportado pela pobre acurácia obtida, $59 \%$. Os autores sugerem novos estudos para confirmar a pobre distinção de sexo nessa fase.

Os autores Kimmerle et al. (2008), ao afirmarem que a estimativa de sexo é um dos quatro pilares do protocolo antropológico, o qual consiste na análise de medidas lineares ou visuais, também acreditam que, muitas vezes, o emprego dessas metodologias pode ser prejudicado em alguns crânios que destoam da média populacional, apresentando-se diferentes do padrão encontrado naquela população. Então, para avaliar o perfil do tamanho e sexo dos crânios numa população americana, eles utilizaram análise geométrica, aplicando 16 medidas craniométricas em 118 esqueletos masculinos e femininos, brancos e negros. Os resultados indicaram diferenças entre os sexos, sendo que nos homens, as medidas apresentaram-se sempre maiores. Porém, com relação ao grupo étnico, não houve diferenças estatísticas nos padrões dos crânios.

Dayal et al. (2008) usaram equipamento e mensurações tradicionais em 120 crânios e mandíbulas (60 de cada gênero), numa população do sul da África. Foram aplicadas 21 medidas lineares e chegou-se às funções discriminantes, obtendo-se 
uma acurácia de 80 a $85 \%$, similares às obtidas com estudos mais complexos. Os autores concluíram que os métodos tradicionais produzem um alto índice de acerto na determinação do sexo.

O forame magno aparece como outra estrutura passível de ser utilizada na determinação do sexo. Gapert et al. (2009) analisaram morfometricamente algumas variáveis nessa região occipital, usando análise por função discriminante e regressão logística. Então, 158 crânios adultos (82 masculinos e 76 femininos) receberam as seguintes mensurações no forame magno: Máximo comprimento, máxima largura e circunferência. Os resultados demonstraram o dimorfismo sexual, com classificação correta para $76 \%$ dos homens e $70 \%$ das mulheres, o que torna essa área do crânio útil na identificação do sexo.

Robinson e Bidmos (2009) pesquisaram 230 crânios de diferentes regiões da África e 264 ossos do braço, com o objetivo de validar cinco equações de função discriminante para sexo, criadas por Steyn e Isca (1998) e apontadas com uma acurácia igual ou maior a $80 \%$. Foram aplicadas 14 medidas (12 no crânio e 2 no úmero), com um intervalo de acerto de 72 a 95,5\%. Os autores concluíram que a equação testada pode ser validada para determinação de sexo em qualquer região do sul da África.

Como outro exemplo de validação, Konisberg et al. (2009) publicaram estudo no qual evidenciaram ser possível a estimativa de sexo utilizando 11 medições no crânio e funções discriminantes. Eles utilizaram medidas baseadas no caso "Mr. Johnson" e na metodologia de Howells (1973) e combinaram duas grandes bases de dados, a base do FDB, encontrada em http://web.utk.edu/ anthrop/FACdatabank.html, e a de Howells, em http://konig.la.utk.edu/howells.htm, com classificação correta do sexo em mais de $76 \%$ dos casos.

Zavando et al. (2009) determinaram o dimorfismo sexual por meio de dimensões lineares convencionais em uma amostra de 226 crânios humanos da Universidade Federal de São Paulo (UNIFESP) usando o cálculo para análise da função discriminante e avaliando sua produtividade. Foram utilizadas medidas dos seguintes pontos de referência do crânio: eurio-eurio (eu-eu), glabela-opistocrânio (g-Op), basio-bregma (ba-br), nasio-próstio (na-pr), bizigomático (zi-zi), largura nasal e násio-espinha nasal anterior (na-ena). Em todas as análises o crânio masculino foi maior que $o$ feminino. $O$ test-t student mostrou $p<0,05$ para a análise discriminante 
com as medidas: g-op, na-ena, na-pr e zi-zi, com uma classificação correta para o dimorfismo sexual de $82,7 \%$.

Hsiao et al. (2010) aplicou 9 medidas cefalométricas em radiografias laterais e análise por função discriminante para estimativa do sexo. Foram analisadas 100 radiografias (50 masculinas e 50 femininas) e a estatística por stepwise mostrou que sete dessas mensurações estavam adequadas, com 91\% de acurácia na determinação do sexo. Os autores terminam o trabalho afirmando que esse método deve ser testado em diferentes populações para confirmar sua efetividade.

Outro trabalho usando medições em radiografias cefalométricas foi realizado por Naikmasur et al. (2010) nos sul - indianos e nos imigrantes tibetanos. Um total de 11 parâmetros cefalométricos foram traçados manualmente nos cefalogramas em norma lateral e em PA. Foi aplicada a análise discriminante, com a formulação de funções. Dentre os parâmetros analisados, a largura bizigomática, a altura do ramo e a profundidade da face foram os que mais contribuíram para o dimorfismo sexual em ambas as populações. A porcentagem de acerto foi de $81,5 \%$ na população sulindiana e de $88,2 \%$ na de imigrantes tibetanos. Os resultados confirmaram que as mensurações cefalométricas crânio-mandibulares podem ser usadas para estimar o sexo através da aplicação de funções discriminantes.

Kharoshah et al. (2010) realizaram um estudo de validação de metodologia utilizando mandíbulas para determinação de sexo em egípcios. Assim, 330 pessoas (165 homens e 165 mulheres) foram submetidas à tomografia computadorizada em 3D e 6 mensurações mandibulares foram aplicadas (ângulo gônio; ramo esquerdo; mínima altura do ramo e largura da base; distância gônio-gnátio; largura bigoníaca e bicondilar). Os dados foram analisados por stepwise. As variáveis que melhor mostraram diferenças entre os sexos foram: largura bicondilar, ângulo gônio e mínima altura do ramo. A acurácia foi de $83,6 \%$ em homens e $84,2 \%$ nas mulheres. Os autores mostraram que essa metodologia pode ser utilizada para distinção de sexo.

Husmann e Samson (2011) desenvolveram um trabalho em que a órbita foi analisada para a determinação de sexo, através das mensurações da altura e largura orbitária. Os resultados indicaram que embora tenham sido encontradas diferenças nas medidas, as mesmas foram muito pequenas para a aplicação prática, sugerindo que isoladamente, tais medidas não devem ser usadas para identificação do gênero. 
Com o objetivo de estabelecer padrões antropométricos para dimorfismo sexual para a população do Norte da Índia, Saini et al (2011a) avaliaram 112 crânios de adultos na idade entre 23 e 65 anos do Departamento de Medicina Forense, Universidade da índia. Assim, foram aplicadas as seguintes medidas: Largura Bizogomática, Comprimento Facial, Altura Facial, Largura e Altura Orbitária, Largura Bi e Interorbitária, Altura e Largura Nasal e comprimento do osso nasal. A Largura Biziogomática foi o melhor parâmetro na análise stepwise, com uma acurácia de $85,5 \%$.

Saini et al. (2011b) estudaram o dimorfismo sexual em 116 mandíbulas na população do Norte da Índia. Foram coletadas informações métricas de cinco parâmetros: altura do processo coronóide, altura do ramo, altura do côndilo, máxima e mínima largura do ramo, com paquímetro. Os parâmetros foram analisados através de função discriminante, com um acerto de $80,2 \%$ e a altura do processo coronóide foi o melhor parâmetro, com acurácia de $74,1 \%$.

Com o objetivo de analisar o índice de acerto da aplicação de medidas envolvendo os ossos posteriores e o crânio todo na determinação de sexo, Spradley e Jantz (2011) construíram modelos de funções discriminantes uni e multivariadas usando os dados do FDB. As medidas escolhidas encontram-se na ficha do FDB (1986). Os resultados indicaram claramente que os elementos posteriores dos crânios apresentaram melhor desempenho na estimativa do sexo, com identificação positiva em $94 \%$ dos casos, enquanto que os melhores modelos usando o crânio todo não excederam $90 \%$. Os autores concluíram que os elementos posteriores podem ser usados na estimativa de sexo quando a utilização da pélvis é inviável.

Sabancıogulları et al. (2012) realizaram estudo com o objetivo de classificar homens e mulheres através da medida da espessura da díploe (membrana os ossos do crânio) e de mensurações de diferentes pontos do crânio. Assim, as medidas foram feitas nas imagens das ressonâncias magnéticas de 305 pacientes (188 mulheres e 117 homens). Para determinar a espessura da díploe foram aplicadas as medidas envolvendo os pontos bregma, lambda, occipital e éurio e para o volume do crânio, as distâncias entre occipital-glabela, básio-opístio, éurio-éurio, násio-básio, bregma-lambda e lambda-occipital. Os resultados indicaram que nos crânios masculinos, todas as medidas foram maiores, com significância estatística $(p<0,05)$, indicando que esse método pode ser utilizado para a estimativa do gênero. 
Considerando a dificuldade da determinação do sexo em casos de fragmentação do crânio, Saini et al. (2012) aplicaram a análise osteométrica do mastóide para a diferenciação sexual. Assim, oito parâmetros da região mastóide foram mensurados em 138 adultos. Pela análise stepwise, as medidas astériomastoidal e largura do mastóide apresentaram uma acurácia de 87\%, reforçando a possibilidade do uso do processo mastóide na identificação do sexo.

Os trabalhos apresentados tornam clara a grande contribuição da antropologia forense nos processos de identificação, particularmente nas questões de estimativa de sexo. O que a maioria dos autores defende é a aplicação das metodologias nas variadas populações para validá-las de acordo com as particularidades da região e, nesse ínterim, pode-se estender tal necessidade à civilização brasileira, considerando, inclusive, sua forte característica multiracial e cultural. Por isso, esta pesquisa teve como objetivo a aplicação de metodologia consagrada na literatura em crânios brasileiros no sentido de colaborar com as pesquisas na área da antropologia forense no país.

\subsection{BIOLOGIA MOLECULAR E IDENTIFICAÇÃO HUMANA}

\subsubsection{Interferência dos fatores técnicos e ambientais na análise por DNA}

Desde os anos 80, quando foi demonstrado que a extração de DNA de material forense era possível, a aplicação de métodos moleculares para resolver questões envolvendo identificação de pessoas tem aumentado, com aceitação judicial. Isso ocorreu porque, muitas vezes, os antropologistas forenses se deparam com restos humanos em avançados estágios de decomposição ou esqueletizados, nos quais os métodos antropológicos convencionais nem sempre fornecem a positiva identificação (Arismendi et al., 2004).

Nos testes de determinação da identidade genética são estudadas regiões genômicas nas quais há variação entre pessoas normais, chamadas regiões polimórficas (Penna, 1997). Um loco polimórfico existe quando duas ou mais seqüências variantes ocorrem em determinado sítio de um cromossomo (Otto et al., 
1998). O método mais utilizado é o estudo de regiões repetidas de DNA, chamadas de minissatélites e microssatélites. A chave de diversidade nessas regiões é 0 número de repetições, que varia entre indivíduos e pode ser estudado com o emprego de sondas de DNA ou com a reação em cadeia da polimerase (PCR) (Kumar; Hedge, 2005).

A invenção da PCR (Reação em Cadeia da Polimerase) tornou possível o uso do DNA mais intensamente em investigações forenses porque essa técnica permite a tipificação do DNA a partir de pequenas amostras de materiais biológicos, comuns em casos forenses. A PCR é aplicada para amplificar regiões polimórficas como short tandem repeats (STRs) do DNA genômico, regiões restritas do genoma, tornando possível a obtenção de valiosas informações para a identificação humana (Morling, 2009).

Além dos minissatélites e microssatélites existem dois grandes grupos de polimorfismos com base na substituição de nucleotídeos únicos (SNPs) e na inserção/deleção. Ambos apresentam a possibilidade de serem estudados em produtos de amplificação muito curtos (50 pb ou menos), apresentando distintas vantagens sobre os microssatélites no estudo do DNA extremamente degradado (como acontece nos casos forenses) (Weber, 2002; Opel et al., 2006).

Do ponto de vista técnico e criminalista, o DNA pode ser coletado de qualquer espécime biológico, pois sendo uma molécula estável em ambiente seco e frio, se armazenado em tais condições, tem grandes chances de resultados confiáveis (Benecke, 2005). Para a antropologia forense, há uma vasta possibilidade de fontes como osso, suor, urina, fezes, impressão papilar, cabelo, etc (Rudin; Inman, 2002). Já na prática odontológica forense, as estruturas dentárias têm sido priorizadas porque a cavidade pulpar - arcabouço formado pelas paredes entre esmalte, dentina e cemento - pode propiciar um meio estável para o DNA. Porém, em esqueletizados desdentados ou em restos ósseos humanos, apenas o osso se presta a análise por DNA, o que justifica seu uso crescente em antropologia forense (Arismendi et al., 2004).

No ataque de 11 de setembro de 2001, nos EUA, com 2.782 vítimas, um total de 1.524 foram identificadas, 785 por DNA e 219 pelos arcos dentários ou dactoloscopia (Budmlija et al., 2003). No atentado em Madri, no dia 11 de março de 2004, o processo de identificação das vítimas (192 mortos) se deu através da dactiloscopia (146/76\%), odontologia (4/2), antropologia (10/5\%) e do DNA (32 
/17\%). Entretanto, isto não significa que exista sobreposição de um método em relação ao outro, pois a escolha da técnica a ser utilizada no processo de identificação está diretamente associada ao tipo de agente lesivo empregado e as condições do material forense (Boadas, 2005).

Protocolos de coleta de amostras detalhados têm sido descritos. O método de coleta específico dependerá do estado e da condição da evidência biológica. Em geral, uma quantidade significativa de material deve ser coletada para garantir a extração de DNA suficiente para os testes. No entanto, é importante preservar a coleta de sujeira adicional, gorduras, fluidos e outros materiais que possam afetar 0 processo de tipagem de DNA (Lee; Laad, 2001).

Deve-se, também, levar em conta que o material biológico recuperado em cenas forenses é susceptível a processos de degradação devido ás condições ambientais variáveis tais como a temperatura, a exposição química e biológica (Lindahl, 1993; Tuross, 1994; Gilbert et al., 2003; Bonaccorso, 2004). De acordo com Sjoholm (2007) e Duarte et al (2010), a taxa e o tempo de deformação do DNA varia conforme a intensidade de exposição a esses agentes, os quais favorecem a contaminação por bactérias e fungos, resultando na alteração física, química e biológica. No vivo, a degradação do DNA é devida aos processos de oxidação e hidrólise, no entanto, os mecanismos de reparação específicos de DNA estão presentes. Após a morte, os ácidos nucléicos sofrem degeneração espontânea e permanecem sem reparos porque essas reações de proteção não estão mais presentes (Arismendi et al., 2004).

Além disso, estudos têm relatado que durante a reação de PCR (Reação em Cadeia da Polimerase), artefatos são gerados devido ao estado de degradação da molécula de DNA advinda de material forense, reduzindo a reprodutibilidade ou produzindo perfis incompletos de STRs por perda alélica, particularmente entre os maiores STRS, causado pelos efeitos estocásticos (Lindahl, 1993; Hoss et al., 1996; Butler, 2001). Também, há os inibidores no ambiente (ex: ácido fúlvico) que dificultam ainda mais a PCR (Tuross, 1994).

No caso das amostras enterradas no solo, é extremamente comum a presença de células vegetais, bactérias, fungos, insetos, entre outros. Em adição, nesse material, há matéria orgânica, representada pelos ácidos húmicos. Tais elementos têm a capacidade de se intercalarem junto ás fitas complementares do DNA e invibializarem a ligação de primers no processo de amplificação, além de 
inibir a ação da enzima Taq DNA polimerase no mesmo processo, sendo, portanto, responsáveis total ou parcialmente, pelas dificuldades ainda encontradas nos processos de identificação (Lakai et al., 2007; Sagova-Mareckova et al, 2008).

O ponto de partida para toda análise por biologia molecular usando dentes é uma boa extração e o manejo dos mesmos, que apresentam algumas particularidades, como descrevem Smith et al. (1997). Dentre as recomendações, os autores sugerem que se preserve a coroa para eventual confronto documental, propondo um corte horizontal na junção amelodentinária com remoção da polpa ou mesmo o aproveitamento de todo o remanescente dentário. Em estudo comparativo, Sweet e Hildebrand (1998) constataram haver um ganho significativo na extração do DNA quando há pulverização dos dentes, com a utilização do nitrogênio líquido.

Já nos casos das extrações de DNA de ossos, estes devem ser previamente limpos com hipoclorito de sódio e etanol, removendo material contaminado da camada mais superficial. Em seguida, devem ser lavados com água destilada e fragmentados utilizando lâminas estéreis. Os pedaços de osso devem ser, então, secos ao ar, se possível, sob irradiação UV de 24 nm por 1 hora. Finalmente, devem ser pulverizados em um pó fino usando nitrogênio líquido (Ricaut et al, 2005; Kim et al., 2008; Gibbon et al., 2009).

Para Cassiman (2000), amostras mais antigas, como dentes e ossos, sempre apresentarão algum tipo de contaminação. $O$ autor recomendou aos laboratórios extremo cuidado para a limpeza da superfície das amostras, previamente à extração do DNA uma vez que o estabelecimento do perfil de DNA de um indivíduo permite a comparação do mesmo com outro perfil obtido a partir de uma amostra biológica.

Arismendi et al. (2004) afirmam que esqueletos e mesmo os remanescentes ósseos humanos processados por antropologistas forenses nas análises podem ser potencialmente usados no estudo genético. Porém, as condições do DNA nessas estruturas podem atrapalhar seu estudo futuro.

Alguns trabalhos analisaram a forma como o meio ambiente pode influenciar na concentração, integridade e recuperação do DNA. Assim, Scwartz et al. (1991) realizaram estudo para verificar a aplicabilidade de amostras dentárias em várias condições. Então, variou-se o pH $(3,7$ e 10,0$)$, a temperatura $\left(4^{\circ} \mathrm{C}, 25^{\circ} \mathrm{C}, 37^{\circ} \mathrm{C}\right.$ e incinerando o dente), a umidade ( $20 \%, 66 \%$ e $98 \%)$, as condições do solo em que foi feita a inumação dos dentes (areia, terra de vaso, terra de jardim, submersão em água e deixados ao relento), e os tempos de inumação (de uma semana a seis 
meses), contatando-se que nenhum desses fatores foram determinantes para a não obtenção de DNA de alto peso molecular a partir de polpas dentárias.

Chen et al. (1994) testaram a influência dos fatores ambientais na determinação do sexo, obtendo DNA de dentes humanos e amplificando por PCR. Os autores variaram o $\mathrm{pH}(2,7$ e 10), a temperatura (-20, 4, 27 e 37ํㅡ), a umidade (20,66\% e imersão) e também submeteram os dentes a soluções contendo $10 \%$ de formol, $75 \%$ de etanol e ao ar livre. Os resultados puderam ser verificados no gel de agarose e confirmaram o potencial de análise do sexo através dos dentes, exceto nos que foram deixados ao ar livre, imersos em água, embebidos em solução de pH igual a 2 e incinerados por 10 minutos, nos quais as bandas de DNA não foram observadas.

Pfeiffer et al. (1999) realizaram um estudo para verificar a influência do solo de jardim na recuperação de DNA de dentes. Os autores armazenaram 44 dentes humanos no solo em intervalos de tempo de 6, 12 e 18 semanas e 1 ano. A extração do DNA foi realizada pelo método orgânico, a amplificação por PCR e os lócus avaliados foram: TH01, vWA, FGA, HV1 e HV2. Os resultados evidenciaram a redução de $90 \%$ da concentração do DNA extraído após 6 semanas de armazenamento, sendo que a amplificação e o sequenciamento direto do genoma mitocondrial foi a técnica de maior sucesso.

Os autores De Leo et al. (2000) avaliaram o potencial de identificação humana através dos dentes submetidos a condições ambientais comuns a casos forenses, com o objetivo de estabelecer um protocolo que preservasse as características morfológicas dos dentes para investigação antropométrica e, ao mesmo tempo, disponibilizasse o máximo de material para análise do DNA.

Para avaliar diferentes tecidos dentários como fontes de DNA em análises forenses, Malaver e Yunis (2003) realizaram um estudo no qual utilizaram 20 dentes obtidos de corpos não identificados, enterrados em 1995 e exumados em 2000, obtendo 45 amostras (cinco de polpa, 20 de dentina e 20 de cemento). A polpa produziu os sinais mais fortes de amplificação por PCR, enquanto que os sinais da dentina e do cemento foram similares entre si.

Cerri et al (2004) expuseram dentes a condições úmidas, secas, substâncias químicas e carbonização para avaliar dois sistemas de amplificação do DNA, confirmando que, em condições extremas, é necessária uma análise mais sensível dos dados para obtenção de informações genéticas. 
Com o objetivo de verificar os efeitos causados na análise de DNA em remanescentes ósseos anteriormente preparados para estudo antropológico, Arismendi et al (2004) avaliaram cinco métodos de processamento utilizados pelos laboratórios de antropologia forense, através da extração de DNA desses ossos e da análise usando um STR (CSF1PO) e amelogenina. Os resultados indicaram que os procedimentos de processamento utilizados por antropólogos forenses não afetam negativamente o estudo do DNA, mas a exposição prolongada ao calor durante 0 processamento pode diminuir o rendimento de informação desse ácido nucléico.

Iwawura et al. (2005) usaram fêmur obtidos de 20 remanescentes encontrados em diferentes graus de decomposição e limpos para remover tecidos contaminados. Alguns loci e a amelogenina foram amplificados por PCR e os resultados indicaram que são necessários cuidados para otimizar a análise forense de ossos por biologia molecular principalmente devido as influências ambientais na degradação do DNA.

Ricaut et al. (2005) extraíram DNA de amostras de ossos e dentes de 10 esqueletos exumados de um sítio arqueológico. O material genético foi analisado por STRs e amelogenina, sendo que das dez amostras estudadas, apenas em uma proveniente de osso não foi possível o padrão alélico determinado. Em todas as amostras, o DNA apareceu muito degradado, no entanto, melhor conservado nos dentes do que nos ossos, indicando nestes um maior processo destrutivo. Entretanto, esse material genético extraído a partir da polpa dental não estava isento dos inibidores na PCR, os quais podem resultar em extrema fragmentação da molécula.

Morgan e colaboradores relataram alguns casos de identificação das vítimas do tsunami ocorrido em Dezembro de 2004 no sul da Ásia, atingido Thailândia, Indonésia e Sri Lanka. Amostras de DNA foram coletadas de grande parte dos corpos e, mesmo que a identificação por material genético não tenha sido o primeiro método de escolha, devido ao maior custo e exigência técnica, boa parte destas amostras foi utilizada com sucesso na identificação destes indivíduos quando dados físicos, impressões digitais e dentárias não puderam ser aplicadas (Morgan et al., 2006).

Objetivando um método para maximizar a recuperação de DNA amplificável por PCR a partir de osso e dos dentes e ao mesmo tempo, para minimizar a co-extracção das substâncias que inibem a PCR, os autores Rohland e Hofreiter (2007) utilizaram um tampão constituído exclusivamente por 
EDTA e proteinase $\mathrm{K}$ para a extração de DNA, e a purificação do mesmo com sílica e tiocianato de guanidina para a remoção dos inibidores da PCR. Todos os passos foram realizados à temperatura ambiente $\left(20-23^{\circ} \mathrm{C}\right)$, reduzindo ainda mais a degradação do DNA do osso, já danificado e frágil. O protocolo apresentado permitiu a extração do DNA a partir de esqueleto e os dentes com um mínimo de passos de trabalho e com equipamentos simples.

Arruda et al. (2007) relataram a problemática de se extrair DNA de ossos datados em cerca de 100 a.C, encontrados em ambiente úmido. A obtenção de boas preparações com DNA de ossos antigos enfrentaram obstáculos tais como os fatores ambientais em que os corpos foram encontrados, além da habilidade técnica da equipe laboratorial e da qualidade dos reagentes utilizados.

Kim et al. (2008) alertaram para os cuidados envolvendo a extração de DNA, principalmente quando se analisam materiais degradados. Os ambientes de extração e PCR e pós-PCR devem ser separados. Deve-se ter muito cuidado com o manuseio das pipetas e controles negativos necessitam ser utilizados para detectar possível contaminação. Esses autores desenvolveram um método de purificação de DNA obtido de amostras de ossos, usando o gene da amelogenina. Assim, 30 amostras de ossos com idade entre 500 e 3.300 anos foram testadas para extração de DNA usando sílica e para PCR, uma coluna de troca iônica. As amostras submetidas a essa técnica apresentaram melhores resultados na amplificação, 0 que sugere uma eficiência da metodologia para esse material.

Para se analisar como a degradação de DNA pode interferir em casos forenses, Rubio et al. (2009) analisaram esse fenômeno degenerativo do DNA em 24 dentes extraídos e armazenados em temperatura ambiente por 0, 2, 5 e 10 anos. A concentração e a quantificação do DNA declinaram significativamente nos primeiros 2 anos, mas não houve grande diferença na degradação nos tempos de 2 a 10 anos. Foi realizada análise para o lócus da amelogenina. Diferenças significantes foram encontradas entre os dentes frescos e os armazenados por 2 anos, o que indica que a degradação ocorreu nesses primeiros anos. Os autores recomendaram mais pesquisas para controlar os fatores externos que podem afetar o DNA.

Faro (2012) analisou quatro protocolos de extração de DNA de 720 amostras de sangue contaminadas com três diferentes tipos de solo, terreno baldio, areia de praia e mangue. Nesse estudo, a metade das extrações foi feita logo após a 
contaminação das amostras e outra metade, depois de 72 horas do contato com 0 solo contaminado. Essas últimas amostras somente amplificaram com as técnicas novas, as quais envolvem a purificação do DNA, porém, apresentaram resultados inferiores se comparadas á primeira metade, extraída logo em seguida do contato do sangue com o solo.

Alguns trabalhos têm pesquisado a questão da degradação do DNA em amostras na busca de alternativas práticas para otimizar e controlar os agentes inibidores das reações de extração e de PCR para análise forense. Tais estudos têm sido feitos principalmente com DNA extraído de dentes e ossos, considerados os elementos mais indicados para a obtenção de DNA nesses casos, devido ao fato de apresentarem maior resistência contra as forças tafonômicas quando comparados aos tecidos moles. Dentre os cuidados recomendados com esse material de origem forense, estão prevenção de contaminação, limpeza das amostras, extração com material adequado, aplicação de produtos para purificação do DNA e para controle de agentes inibidores da PCR e uso de controles negativos. Além disso, dependendo da condição da amostra, deve-se realizar mais de uma extração e reação de PCR, para escolha do melhor resultado (Hebsgaard et al., 2005; Ricaut et al., 2005; Rohland; Hofreiter, 2007; Cardoso et al., 2008; Kim et al., 2008; Millar et al., 2008; Mundorff et al., 2009; Rios et al., 2010; Woide et al., 2010; Betancor et al., 2011; Lupta'kova et al., 2011; Campos et al., 2012; Knapp et al., 2012).

\subsubsection{Biologia Molecular e dimorfismo sexual}

As técnicas antropológicas para a investigação do sexo, ditas clássicas e de rotina, podem sofrer limitação em sua aplicabilidade em algumas ocasiões. É o que se observa, dentre outros casos, quando da determinação do sexo em jovens na fase pré-puberal, crianças e bebês; em corpos mutilados sem possibilidade de reconhecimento; e em restos mortais encontrados em suas partes (Arbenz, 1988).

Por seu turno, um dos métodos adjuvantes no estabelecimento do sexo biológico é a análise da molécula do ácido desoxirribonucleico (DNA) a qual pode ser comparada a um código de barras capaz não só de identificar, mas também de 
comparar pessoas, determinando inclusive a existência ou não de vínculo genético entre estes (Slavkin,1997).

Nessas análises de DNA para determinação do sexo, tradicionalmente, a amelogenina tem sido utilizada, e tornou-se um método padronizado nos kits usados na identificação humana, acompanhando os STRs, com resultados excelentes na elucidação de casos forenses como desaparecimentos, esqueletos não identificados, desastres em massa, casos de abuso sexual (Meissner et al., 2007; Mulero et al., 2008; Hill et al., 2009).

A amelogenina ou AMEL é uma proteína secretada pelos ameloblastos, encontrada no esmalte dentário e apresenta distinções entre os sexos quanto ao tamanho e ao padrão de seqüência de nucleotídeos (Lattanzi et al., 2005). No teste, sequências homólogas nesse primer, localizados nos cromossomos $X$ e $Y$ (AMELX e AMELY), são simultaneamente amplificados, e a amostra feminina pode ser discriminada de um falso negativo pelo pico único derivado do cromossomo X. O lócus da amelogenina apresenta um alelo de 106 pares de base nas mulheres e um de 106 e outro de 112 pares de bases nos homens, permitindo, assim, a distinção dos sexos (Figini et al., 2003).

No entanto, embora ainda considerados raros, erros de identificação de um homem por mulher podem ocorrer quando o indivíduo masculino tem uma deleção Yp envolvendo AMELY, que tem sido encontrada em algumas populações. Por isso, alguns kits estão utilizando STRs no cromossomo $\mathrm{Y}$, além da amelogenina, na determinação do sexo (Steinlechner et al., 2002; Michael; Brauner, 2004; Lattanzi et al., 2005; Kashyap et al., 2006; Chang et al., 2007).

A amelogenina também tem sido empregada para identificação de sexo em casos de acidentes de massa, catástrofes e acidentes naturais. Clayton et al. (1995) descreveram o trabalho realizado na identificação das vítimas de uma explosão ocorrida em 1993, no Texas. Do total de 61 corpos, 21 foram identificados através das características dentárias, dactiloscopia e radiografias. Para as demais, utilizouse um programa de DNA que analisava quatro STRs e a amelogenina para investigação do sexo.

Faerman et al. (1995), estudaram a identificação do sexo biológico em restos ósseos humanos encontrados em um sítio arqueológico de Israel, com idade entre 200 e 8100 anos, através da extração e amplificação do DNA. Foi possível a 
obtenção de resultados satisfatórios independente da idade das amostras e do local em que foram encontradas.

Stone et al. (1996) realizaram estudo no qual extraíram DNA de osso de 20 esqueletos de um sítio arqueológico e do sangue de 20 indivíduos. O sexo de 19 desses esqueletos e dos 20 indivíduos foi corretamente determinado usando PCR e o gene amelogenina. Os autores concluíram que os remanescentes fragmentados podem ser identificados por DNA quando técnicas morfológicas são difíceis ou impossíveis de se aplicar.

Smith et al. (1997) reportaram a análise de DNA de 43 restos ósseos encontrados em Roma, referentes ao século IV, supostamente de crianças vítimas de infanticídio. O sexo foi determinado pela amplificação do gene amelogenina, pois a análise morfométrica em crianças, especialmente naquelas cujo esqueleto ainda não se apresentava completo, não forneceu confiabilidade aos resultados.

Urbani et al. (1999) investigaram a eficácia da utilização do DNA de polpas dentárias expostas a diferentes condições de temperatura, em variados períodos de tempo, para determinação do sexo. Obtiveram 100\% de amplificação do lócus da amelogenina através da PCR, confirmando a aplicabilidade do método na estimativa do sexo.

Meyer et al. (2000) obteve uma taxa de mais de $90 \%$ de sucesso na amplificação com amelogenina usando amostras de dentes e remanescentes ósseos antigos. Primeiramente, o sexo foi determinado antropologicamente e, posteriormente foi feita a análise por biologia molecular. Sivagami et al. (2000), reportando a dificuldade de se extrair DNA tendo como substratos somente tecidos duros dentários, obtiveram sucesso no diagnóstico do sexo com o gene AMEL, utilizando nitrogênio líquido para pulverizar as estruturas dentárias.

Com o intuito de reforçar a importância da determinação do sexo através da amelogenina nos casos forenses, tanto em investigações criminais, como em desaparecimento de pessoas e mesmo no estudo de ossos antigos, Andréasson e Allen (2003) mostraram uma eficiência na aplicação da PCR em tempo real para identificação do sexo. Os autores afirmaram ser o método rápido, efetivo e flexível para uso nas análises forenses.

Yoshida et al. (2005) avaliaram o potencial de investigação do sexo de dentes e ossos através do DNA, utilizando como lócus a amelogenina e os marcadores DYZ-1, DYZ-3 e DXZ-1. Neste trabalho verificaram que a determinação do sexo em 
dentes frescos pode ser feita com sucesso usando qualquer marcador dos cromossomos sexuais. Entretanto, em amostras submetidas a condições ambientais por muito tempo ou em estágio avançado de decomposição é necessária a associação de dois ou mais marcadores moleculares para a obtenção de um resultado mais preciso, quando somente o estudo genético é realizado.

Ainda no que se refere à DNA degradado, Tschentscher et al. (2008) desenvolveram um ensaio que permite a determinação do sexo por sequenciamento de pequenos produtos da PCR. Um trecho contendo 48/45-bp, incluindo primers para o gene amelogenina com uma inserção de $3 \mathrm{bp}$ no cromossomo $\mathrm{Y}$, foi escolhido para análise. Inicialmente, amostras de 50 homens e 50 mulheres sem parentesco foram corretamente tipadas. Eles testaram também 7 amostras de DNA extraídas de ossos que ficaram enterrados de 1 a 2 anos e que falharam na convencional tipagem por STR devido à degradação, e obtiveram resposta positiva em 6 delas. $O$ método mostrou ser eficiente e é vantajoso quando se lida com amostras de DNA degradadas.

Velarde-Félix et al. (2008) realizaram estudo cego, observacional, comparativo e transversal em 457 amostras sanguíneas, com a finalidade de determinar o sexo a partir da amplificação do gene amelogenina. Como resultado, houve concordância de $100 \%$ entre a amplificação obtida e o sexo real dos indivíduos participantes.

Gibbon et al. (2009) aplicaram dois sistemas de identificação do sexo molecular utilizando regiões diferentes do gene amelogenina, conforme a diferença entre homens e mulheres. O estudo foi feito em esqueletos com $46,66 \%$ de acerto, o que os autores consideraram um resultado dentro da normalidade para pesquisas com DNA.

Takayama et al. (2009) observaram a questão da deleção do alelo $Y$ em um caso masculino que foi diagnosticado como falso feminino usando os kits convencionais. Foram aplicadas análises em um total de 60 loci de STRs-Y e observaram-se as regiões com deleção e os tamanhos das mesmas. Os autores afirmaram que a tipagem do sexo baseada na amelogenina é uma parte integrante da maior parte dos kits de PCR, amplamente utilizada para a determinação do sexo e desempenha um papel importante na resolução de casos forenses, porém, os resultados errados podem levar à confusão. Por isso, embora o aparecimento de homens falsos seja raro na maioria das populações, deve ser considerada a 
possibilidade de realização de outros testes para complementar a determinação do gênero, principalmente nos casos duvidosos.

Lupta'kova' et al. (2011) estudaram a identificação do sexo em 25 esqueletos da Idade Média, encontrados na Eslováquia. Tornou-se necessária a associação de técnicas da biologia molecular, pois a amostra, outrora analisada e tratada com métodos antropológicos e arqueológicos, apresentava-se altamente degradada. Como a amplificação da amelogenina para determinação do sexo pode apresentar falsos resultados, as regiões eleitas para amplificação e determinação do sexo foram as dos genes SRY e DXZ4, pois além de constituírem fragmento com menor número de pares de bases em relação ao gene amelogenina, permitiram o trabalho com material escasso, determinando o sexo em $92 \%$ da amostra.

Ainda avaliando a determinação sexual pelo DNA em esqueletos de sítios arqueológicos datados dos séculos 18 e 19, Daskalaki et al. (2011) testaram e validaram uma metodologia baseada no gene amelogenina. $O$ médoto foi aplicado em 13 esqueletos com registros prévios. Os resultados indicaram que 11 das amostras tiveram o sexo determinado com sucesso, mostrando que a deleção alélica apareceu com um risco de erro de classificação de macho por fêmea inferior a $0,01 \%$.

Considerando a questão do falso masculino, Morikawa et al. (2011) desenvolveram um método para discriminação entre homens e mulheres utilizando três primers, amelogenina, SRY e STS em 246 amostras de sangue, com identificação positiva em todas as amostras. A consideração errônea ocorreu apenas em uma amostra no lócus da amelogenina, sendo a mesma corrigida com o uso dos outros genes. O método mostrou ser preciso e confiável.

Turrina et al. (2011) descreveram dois casos de identificação falsa com amelogenina, através da aplicação de 23 sequências de STSs. Os autores afirmaram que como os resultados errôneos podem gerar sérias implicações, o diagnóstico usando a amelogenina, em casos de dúvida, deve ser complementado com um marcador do cromossomo $\mathrm{Y}$.

Li et al. (2012) analisaram um método com a amelogenina para determinação do sexo em amostras de quatro ossos e um dente. De acordo com os resultados, as quatro amostras ósseas puderam ter o sexo determinado com clareza, porém, o que não ocorreu com a amostra de dente provavelmente devido a insuficiência de 
material (quantidade inferior a $0,15 \mathrm{~g}$ ). Os autores concluíram que a metodologia foi fácil, rápida, barata e adaptável.

Santos (2012) realizou pesquisa isolando o gene amelogenina para a investigação de sexo biológico. Para tanto, foram utilizadas 52 polpas dentais obtidas de dentes extraídos de corpos em decomposição. Não foi possível determinar o sexo em $15,4 \%$ dos dentes, porém, houve concordância de $95,5 \%$ entre a determinação do sexo biológico e o real dos indivíduos nas amostras positivamente identificadas. Dentre as masculinas, houve discordância de 5,6\% entre o sexo real e o sexo obtido pela amplificação, revelando resultado de falsofeminino, ou seja, indivíduos masculinos com genótipo XX em apenas dois casos (AMEL X). Concluiu-se que, apesar da amostra ser composta por material degradado, a amplificação da amelogenina apresentou resultados satisfatórios na investigação do sexo biológico, mostrando-se como uma metodologia de ótimo custo-benefício capaz de complementar os estudos antropológicos de identificação humana.

A literatura é rica em trabalhos nos qual foi utilizado DNA para identificação humana, porém, em várias situações, métodos antropológicos foram concomitantemente aplicados, chegando-se à excelentes resultados, sugerindo como eficiente a aplicação dos dois métodos conjuntamente (Oliveira et al., 2002; Boadas, 2005; Vanek et al., 2009). Seguindo esta idéia, esse estudo teve o objetivo de aplicar a antropologia física e a análise de DNA na determinação do sexo de esqueletos exumados do cemitério de Guarulhos, SP, verificando o potencial de cada método. 


\section{PROPOSIÇÃO}

Este trabalho teve como proposições:

1. Aplicar três metodologias de Antropologica Física para estimar o sexo de crânios, verificando a acurácia das mesmas para a população brasileira na região estudada (São Paulo).

2. Verificar quais parâmetros quantitativos e qualitativos foram mais significativos para o dimorfismo sexual.

3. Analisar o sexo genético pelo gene amelogenina (AMEL) na mesma coleção.

4. Comparar os resultados obtidos na análise antropológica com o DNA. 


\section{MATERIAL E MÉTODOS}

\subsection{MATERIAL}

\subsubsection{Amostra}

A amostra foi de conveniência, composta de 66 crânios $(n=66)$, todos com registros seguros quanto à idade, procedência e sexo, sendo 32 femininos e 34 masculinos. Os esqueletos foram exumados do cemitério de Guarulhos. Pela rotina do Serviço, esses esqueletos estavam inumados há pelo menos três anos e como não foram retirados pela família após o prazo legal, passaram a fazer parte do acervo do Serviço de Antropologia Forense do IML, sob a coordenação do Prof. Dr. Luiz Airton Saavedra de Paiva. Então, foram utilizados neste estudo, o qual teve a autorização do chefe do Centro de Estudo e Pesquisa em Ciências Forenses, Guarulhos (Anexo A).

Como critérios de inclusão dos crânios na pesquisa avaliou-se a integridade dos mesmos e se pertenciam a indivíduos maiores que 20 anos. Os critérios de exclusão foram trauma e fratura extensos e ausência da mandíbula. Para a análise por DNA, um dos crânios (002/10) foi excluído porque havia sido submetido ao processo de limpeza físico-química antes da coleta do material. Os esqueletos foram exumados e armazenados e sacos plásticos, devidamente identificados (Figura 4.1). Como esses esqueletos foram disponibilizados para estudos, para essa pesquisa foram removidos um ou dois dentes ou duas a três vértebras, nos casos dos crânios com maxila e mandíbula desdentados. $\mathrm{Na}$ escolha dos dentes, dava-se preferência aos molares, devido a maior quantidade de tecido para extração de DNA. Já as vértebras eram escolhidas entre as quarta e sexta vértebras, com maior quantidade de osso.

O estudo genético foi realizado no Laboratório de DNA do Departamento de Odontologia Social da FO-USP, sob a coordenação do Prof. Rogério Nogueira de Oliveira e no Laboratório de Genética do Hospital de Anomalias Crânio-faciais Centrinho (HRACF-USP), sob a responsabilidade da Prof ${ }^{-}$Dr $^{\underline{a}}$. Lucilene Arilho 
Ribeiro Bicudo (Anexo B). Após a remoção dos dentes e ossos, esses crânios passaram por um processo de limpeza físico-químico, envolvendo fervura, aplicação de hipoclorito de sódio e secagem ao sol. Em seguida, foram realizadas medidas antropológicas nos crânios com a finalidade de estimar o sexo.

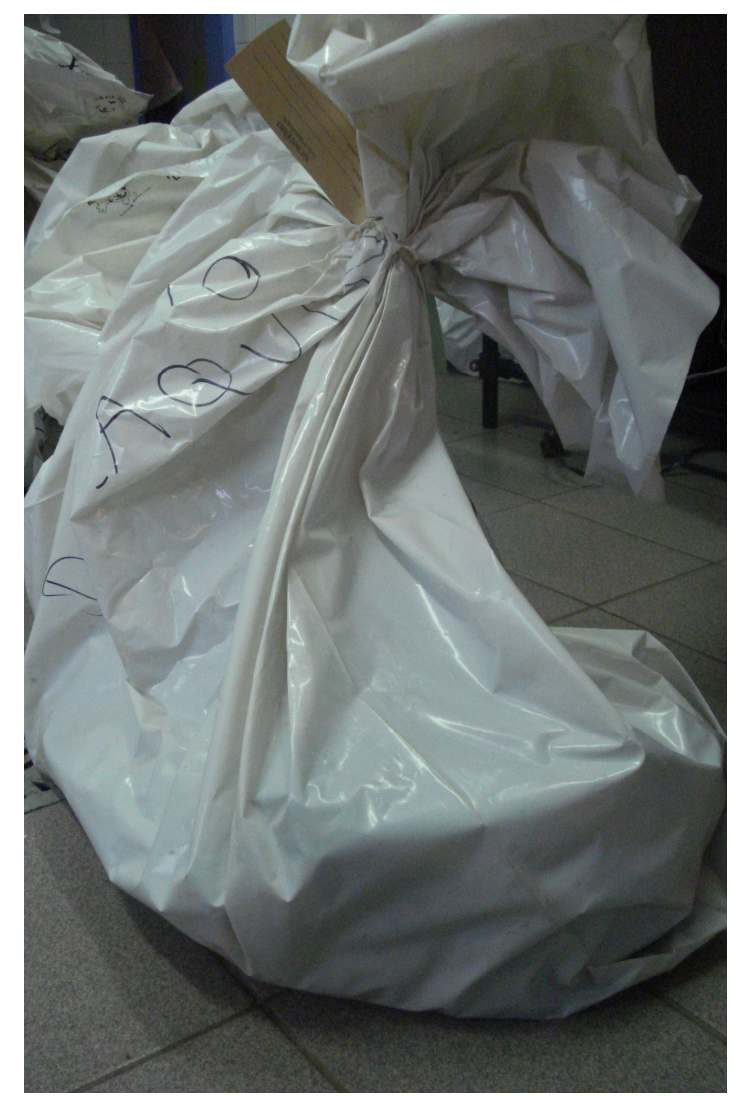

Figura 4.1 - Saco plástico contendo o esqueleto identificado

\subsubsection{Materiais usados na Antropologia Física}

As medidas foram realizadas com paquímetro digital de precisão de ponta normal e com a ponta estendida, compasso de ponta curva nas regiões onde não era compatível o uso do paquímetro, o mandibulômetro para algumas medições mandibulares e o compasso para medida do ângulo mandibular. 


\subsection{MÉTODOS}

\subsubsection{Atendimento às normas de bioética}

Este projeto de pesquisa foi enviado ao Comitê de Ética em Pesquisa da Faculdade de Odontologia de São Paulo (USP) e foi aprovado com o protocolo de número 138/2010 (Anexo C).

\subsubsection{Calibração das pesquisadoras para a análise antropológica dos crânios}

Previamente ao estudo piloto, as pesquisadoras realizaram um treinamento dos métodos, pontos e medidas sob o acompanhamento de uma professora de anatomia. O estudo piloto foi realizado com uma série de testes para avaliar a magnitude do erro inter e intraobservador inerentes ao sistema de pontuação, para os métodos antropológicos utilizadas na pesquisa. Para avaliar 0 erro interobservador, foram feitas todas as medições pelas duas pesquisadoras em trinta e dois crânios. Para avaliar o erro intraobservador, somente a pesquisadora que aplicou as metodologias repetiu as mesmas medições em 14 crânios num período de aproximadamente 1 mês.

Duas pesquisadoras participaram da calibração. Depois da calibração, apenas uma pesquisadora realizou a aplicação de todas as metodologias na amostra. As pesquisadoras desconheciam o sexo dos esqueletos examinados.

Para as mensurações quantitativas (FDB, 1986; Oliveira et al., 1995), aplicouse o Teste "t" pareado e para a qualitativa (Walker, 2008), utilizou-se o índice Kappa. 


\subsubsection{Análise e tabulação dos resultados}

As medidas encontradas foram anotadas na ficha específica para registro de medidas, criada para este fim (Anexo D). Todas as medidas foram realizadas em milímetros. Os dados obtidos na análise antropológica foram tabulados utilizando-se o programa Excell (Microsoft Office $\AA$ ). Os procedimentos estatísticos foram executados no Programa STATA 12, com um nível de significância de 5\%.

\subsubsection{Análise antropológica: Metodologia de Walker}

O Método foi utilizado em um estudo feito em 2008, envolvendo três diferentes populações, com acurácia de $88 \%$. Esse fator foi relevante para a escolha do Método, já que possibilitou uma comparação com os resultados colhidos na população brasileira. O método avalia facilmente os seguintes critérios morfológicos: protuberância mentual, a margem supraorbital, a glabela, a crista occipital externa e o processo mastóide (Figura 4.2). De acordo com Walker, a lista dos critérios craniais analisados é baseada no trabalho "Padrões para Coleta de Dados de Remanescentes do Esqueleto Humano" (Buikstra; Ubelaker, 1994). Os elementos cranianos foram selecionados com base na literatura, na experiência pessoal do autor e na praticidade da aplicação. Embora ocorram algumas diferenças entre populações, esses elementos apresentam um alto dimorfismo sexual e são tradicionalmente usados pelos antropologistas (Quadro 4.1).

A acuidade visual é usada para classificar os elementos analisados nos escores entre 1 e 5 e a gradação cresce a medida que aumenta a expressão do elemento (Figura 4.2). De modo geral, pode-se afirmar que os critérios 1 e 2 indicam as estruturas mais delicadas, menos pronunciadas, menos robustas e angulares, entretanto, mais finas e menores, mais comuns em mulheres. Por outro lado, os critérios maiores, como os de número 4 e 5 classificam estruturas mais largas, mais rugosas e angulares, características masculinas. 


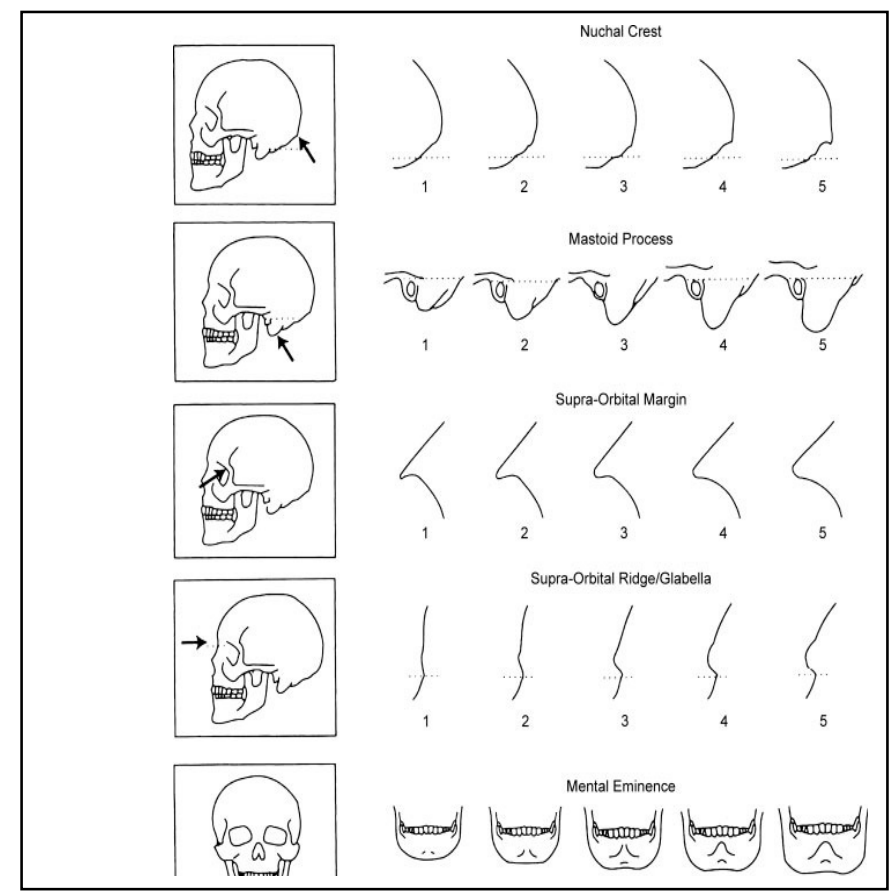

Figura 4.2 - Padrão para marcação dos traços cranianos (Walker, 2008). Os números abaixo dos diagramas são os escores para serem atribuídos aos espécimes cuja morfologia se assemelha ao estado ilustrado

\begin{tabular}{|c|c|c|}
\hline Elemento & Homem (5) & Mulher (1) \\
\hline $\begin{array}{l}\text { Protuberância } \\
\text { Mentual }\end{array}$ & $\begin{array}{l}\text { Maciça, ocupa a maior parte da } \\
\text { parte anterior da mandíbula }\end{array}$ & $\begin{array}{l}\text { Suave, pouca ou nenhuma } \\
\text { projeção sobe a superfície do } \\
\text { osso }\end{array}$ \\
\hline $\begin{array}{l}\text { Margem } \\
\text { Supraorbital }\end{array}$ & Romba; borda arredondada. & $\begin{array}{l}\text { Borda cortante; extremamente } \\
\text { fina }\end{array}$ \\
\hline Glabela & $\begin{array}{l}\text { Glabela e margem supraorbital } \\
\text { são grandes, formando um } \\
\text { contorno arredondado. }\end{array}$ & $\begin{array}{l}\text { Contorno do osso frontal é suave, } \\
\text { com pouca ou nenhuma } \\
\text { projeção; pouco pronunciada. }\end{array}$ \\
\hline $\begin{array}{ll}\text { Crista } & \text { Occipital } \\
\text { Externa } & \end{array}$ & $\begin{array}{l}\text { Superfície saliente e bem } \\
\text { marcada, formando gancho. }\end{array}$ & $\begin{array}{l}\text { Superfície externa lisa, sem } \\
\text { saliências ósseas. }\end{array}$ \\
\hline Processo Mastóide & $\begin{array}{l}\text { Mais robusto; com altura e } \\
\text { largura de diâmetro diversas } \\
\text { vezes maior que o do poro } \\
\text { acústico externo. }\end{array}$ & $\begin{array}{l}\text { Mais curto; projeta-se á pequena } \\
\text { distância abaixo da margem } \\
\text { inferior do poro acústico externo. }\end{array}$ \\
\hline
\end{tabular}

Quadro 4.1 - Descrição dos elementos para análise somatoscópica dos crânios pelo Método de Walker (2008) 
4.2.4.1 Análise estatística da Metodologia de Walker

Primeiramente, foi feita a distribuição das variáveis qualitativas segundo as categorias. Em seguida, calcularam-se a média e o desvio padrão. Foram aplicadas a análise discriminante linear e a logística para a determinação do sexo utilizando várias combinações de variáveis independentes. Posteriormente, por meio da regressão logística multivariada foram obtidas as funções para a determinação do sexo. Finalmente, foram feitas estatísticas para comparar a associação dos sexos estimados e observados com a metodologia de Walker, segundo a fórmula proposta pelo autor.

A função discriminante usada foi:

Logito $=($ glabela $x-1.375)+($ Processo mastóideo $x-1.185)+$ (Protuberância Mentual $x-1.150)+9.128$

A probabilidade de ser do sexo feminino (PF) e do masculino (PM) foi calculada segundo as equações:

$P F=1 /\left(1+e^{- \text {logito }}\right)$
$P M=1-P F$

\subsubsection{Método do Forensic Data Antropology Bank}

O Banco de dados de Antropologia Forense (FDB) foi iniciado em 1986, com uma bolsa do Instituto Nacional de Justiça, na Universidade do Tennesse, nos Estados Unidos da América (EUA). O FDB contém informações demográficas extensas para muitos casos, como local de nascimento, histórico médico, profissão, 
estatura e peso. As informações esqueléticas dos casos incluem medidas cranianas e pós-cranianas, informações de fechamento de sutura, vários critérios de envelhecimento, informações cranianas não métricas, traumas, traços congênitos, e observações dentárias. Além disso, o Banco começou a recolher dados em 3D de casos que vêm da Universidade do Tennessee e de outras instituições contribuidoras. O FDB tem aproximadamente 3.400 casos, sendo que mais de 2.400 apresentam sexo e ancestralidade definidos. Muitos destes têm sido medidos e enviados por vários antropólogos forenses em todo os EUA. Assim, o Banco já teve a contribuição de mais de 100 antropólogos forenses.

O método do FBD (1986) consiste nas trinta e quatro seguintes medidas cranianas, discriminadas no Anexo $\mathrm{E}$.

1. Comprimento Máximo do Crânio (Glabela-Opistocrânio) (g-op).

2. Largura Máxima do Crânio (Biéurio) (eu-eu).

3. Largura Bizigomática (zy-zy).

4. Altura Básio- Bregma (ba-b).

5. Comprimento Básio-Násio (ba-n).

6. Comprimento Básio-Próstio (ba-pr).

7. Máxima Largura Alveolar (ecm-ecm).

8. Máximo Comprimento Alveolar (pr-alv).

9. Largura Biauricular (AUB).

10. Altura Facial Superior (n-pr).

11. Mínima Largura Frontal (ft-ft).

12. Largura Facial Superior (fmt-fmt).

13. Altura Nasal (n-ns).

14. Largura Nasal (al-al).

15. Largura Orbitária (d-ec).

16. Altura Órbita $(\mathrm{OBH})$.

17. Largura Biorbitária (ec-ec).

18. Largura Interorbitária (d-d).

19. Corda Frontal (n-b).

20. Corda Parietal (b-l).

21. Corda Occipital (I-o).

22. Comprimento do Forame Magno (ba-o). 
23. Largura do Forame Magno (FOB).

24. Comprimento do Mastoide (MDH).

25. Altura do queixo (gn-id).

26. Altura do Corpo da Mandíbula no Forame Mentoniano.

27. Espessura do Corpo da Mandíbula no Forame Mentoniano.

28. Diâmetro Bigonial (go-go).

29. Largura Bicondilar (cdl-cdl).

30. Largura Mínima do Ramo Mandibular.

31. Máxima Largura do Ramo Mandibular.

32. Máxima Altura do Ramo Mandibular.

33. Comprimento Mandibular.

34. Ângulo Mandibular.

\subsubsection{Análise estatística do Método FDB}

Primeiramente, foi realizado um estudo descritivo dos dados, calculando-se a média e o desvio padrão das variáveis para os dois sexos, masculino e feminino. Além disso, a análise discriminante linear e a logística foram aplicadas para verificar as porcentagens de acerto na classificação dos crânios em masculinos e femininos, com o objetivo de determinar qual o melhor modelo para discriminar os sexos e quais medidas foram mais relevantes. Finalmente, foi realizada a regressão logística através da qual foram obtidas as fórmulas para determinação do sexo.

\subsubsection{Método de Oliveira}

A metodologia de Oliveira et al. (1995) foi baseada num método já descrito na Literatura, de Lagunas (1974), que faz uso de quatro medidas mandibulares para discriminação do sexo (Distância Bigoníaca, Altura do Ramo Mandibular, Comprimento Total da Mandíbula e Largura Mínima do Ramo Mandibular). Na análise estatística do Método de Oliveira, somente as medidas Distância Bigoníaca e 
Altura do ramo mandibular forneceram resultados satisfatórios para a população estudada, de modo que as outras duas mensurações não foram consideradas na fórmula final.

As medidas da metodologia de Oliveira et al. (1995) referem-se as duas abaixo citadas, já comentadas no Método FDB, 1986 (Anexo E).

1. Distância bigoníaca.

2. Altura do ramo mandibular.

4.2.6.1 Análise estatística do Método de Oliveira

$\mathrm{Na}$ análise estatística da Metodologia de Oliveira et al. (1995), foi utilizada a regressão logística, com a finalidade de se propor a determinação do sexo a partir das medidas tomadas na mandíbula, com a seguinte fórmula:

logito $(p)=21,9466-0,2444 \times$ altura do ramo $-0,0812 \times$ largura bigoníaca

Esse logito permitiu a definição da probabilidade de pertinência de uma mandíbula ao sexo feminino através da equação:

$$
p=e^{\text {logito }} /\left(1+e^{\text {logito }}\right)
$$

Finalmente, foram feitas estatísticas para comparar os resultados obtidos, segundo a fórmula proposta pelo autor. 


\subsubsection{Análise por Biologia Molecular}

4.2.7.1 Análise das condições ambientais da região de coleta das amostras

As informações sobre as condições ambientais foram obtidas por dados oficiais do IBGE (Brasil, 2012). O pH foi obtido pelo método colorimétrico.

\subsubsection{Coleta dos dentes e das vértebras}

Após a exumação dos esqueletos, os crânios foram separados e foram removidos um ou dois dentes, preferencialmente o molar, para análise do DNA. Os elementos dentários foram retirados com auxílio de extratores e armazenados em potes de plástico até o momento da extração do DNA. Nos casos em que os elementos dentários estavam ausentes, foram removidas duas ou três vértebras para extração de DNA. Estas foram armazenadas em sacos plásticas até a extração.

É importante descrever que tanto os dentes como as vértebras apresentavam-se molhadas, com muita sujeira advinda do contato com o solo úmido. Especialmente as vértebras estavam esbranquiçadas em alguns pontos e amareladas em outros, com aparência oca e escavada. Os dentes, na sua maioria, tinham cáries, restaurações, descalcificações e desgastes na oclusal. A situação de cada elemento foi descrita para confronto com os resultados. Assim, os dentes e as vértebras foram classificados em condição ruim, caso apresentassem qualquer tipo de alteração e condição boa, quando estavam regulares e satisfatórios para a análise por DNA. 


\subsubsection{Preparo dos dentes}

Os dentes foram submetidos a um processo de limpeza físico-química através da realização de raspagens com curetas periodontais e lavagem com álcool $70 \%$. Em seguida, foram acondicionados em potes plásticos e mantidos à temperatura negativa de $20^{\circ} \mathrm{C}$. Os dentes foram seccionados em sua porção coronária com disco de carborundo esterilizado, substituído para cada unidade e depois, pulverizados. Foi realizado o método de Sweet e Hildebrand (1998) adaptado com o uso de um grau e pistilo de porcelana e estocagens manuais. Para a pulverização dos elementos dentários foram realizadas de 3 a 4 imersões em nitrogênio líquido mantendo as batidas do pistilo constantes. Foi utilizada de 1 a $5 \mathrm{~g}$ de cada amostra dentária pulverizada.

\subsubsection{Preparo das vértebras}

O preparo das vértebras obedeceu ao protocolo descrito por Kemp e Smith (2005). As vértebras foram limpas agressivamente com uma lixa para remover a camada exterior de material estranho e qualquer contaminação que pudesse interferir na análise por DNA. Os fragmentos ósseos foram limpos com álcool e água sanitária diluída por 20 minutos e enxaguados com água destilada estéril. Em seguida, foram fragmentados em pedaços muito pequenos utilizando serra manual de fita. Os pedaços de ossos foram, então, secos ao ar. Utilizou-se de 1 a $5 \mathrm{~g}$ de amostra óssea pulverizada.

\subsubsection{Extração do DNA}

A extração do DNA dos dentes e das vértebras foi realizada de acordo com as instruções do fabricante do Kit QIAamp DNA Investigator Kit, da marca Qiagen (Quiagen ${ }^{\mathrm{TM}}$ ). 
Após a extração do DNA, procedeu-se com a corrida eletroforética em gel de agarose a $1 \%$, juntamente com um marcador de peso molecular de 100 pares de bases e visualização da imagem fotografada para confirmar presença de material genético (gel de integridade). Previamente a aplicação da técnica de PCR, realizouse a quantificação do DNA no equipamento Espectrofotômetro NanoDrop 2000 (Thermo Scientific ${ }^{\text {TM }}$ ) (Anexo F).

\subsubsection{Reações de PCR e primer utilizado}

Conforme relatado (Farah, 2007), a técnica conhecida como PCR é baseada na estrutura e na sequência do DNA. Na prática o que se faz é adicionar em um tubo de ensaio uma quantidade pequena de DNA genômico, mais os quatro nucleotídeos que compõem a cadeia de DNA (dCTP, dATP, dGTP e dTTP), a enzima polimerase do DNA, os oligonucleotídeos que servirão de primers e a solução-tampão (fornece as condições de $\mathrm{pH}$ e salinidade necessárias).

Procede-se ao aquecimento da molécula de DNA (dupla hélice) à temperatura de $94^{\circ} \mathrm{C}$ por cinco minutos, para que suas pontes de hidrogênio se quebrem e, há a separação das hélices, processo denominado de desnaturação. Quando esta solução é vagarosamente resfriada $\left(30^{\circ} \mathrm{C}\right.$ a $65^{\circ} \mathrm{C}$ por 30 segundos), cada hélice encontra-se com sua complementar e a estrutura de dupla hélice reconstitui-se, processo conhecido como anelamento, permitindo a hibridização entre a hélice (que é unitária) e o primer presente no meio.

Com o novo aumento da temperatura $\left(72^{\circ} \mathrm{C}\right.$ por 30 segundos a 2 minutos), a enzima TaqDNA polimerase, fornece energia à reação, incorporando o nucleotídeo na posição terminal do primer, promovendo a elongação da cadeia, sendo este o processo de extensão. O conjunto de reações em série de desnaturação, anelamento e extensão é definido como um ciclo que resulta na amplificação da sequência de DNA desejada.

A região escolhida para amplificação pela técnica de PCR foi a amelogenina, cuja seqüência de primers está apresentada no Quadro 4.2. Os primers foram sintetizados pela empresa Life Technologies Brasil Comércio e Indústria de Produtos 
para Biotecnologia LTDA, sendo um marcado com fluorescência 6FAM e o outro não marcado.

Importante ressaltar aqui que, apesar da amelogenina representar uma região funcional do DNA (gene), a mesma foi utilizada exclusivamente com fins de estimativa de sexo para identificação humana, sendo que não foi observado, durante o andamento desta pesquisa, nenhum outro tipo de característica dos indivíduos envolvidos.

\begin{tabular}{|l|c|}
\hline Nome do Primer & \multicolumn{1}{|c|}{ Sequência 5’ 3’ $^{\prime}$} \\
\hline AMEL F & GTTTCTTCCCTGGGCTCTGTAAAGAATAGTG \\
\hline AMEL R & ATCAGAGCTTAAACTGGGAAGCTG [6-FAM] \\
\hline
\end{tabular}

Quadro 4.2 - Sequência, concentrações e tamanho dos produtos das PCR do loci amelogenina

Para a reação de PCR, foi utilizado o Termociclador Veriti 96 well (Applied Biosystems $^{\mathrm{TM}}$ ). Foi obtida uma mistura com volume total de $15 \mu \mathrm{L}$, contendo água, tampão, dNTPs, Primer, DNA polimerase e DNA molde, conforme explicitado no Quadro 4.3. Como controle positivo foi utilizado DNA humano advindo do sangue, após comprovado sua efetividade. Já o controle negativo consistiu na substituição do DNA por água, assim sendo possível detectar possíveis contaminações de alguns dos reagentes requisitados para a reação de PCR. A ciclagem utilizada está descrita no Quadro 4.4.

\begin{tabular}{|l|c|}
\hline REAGENTES & CONCENTRAÇÃo \\
\hline Tampão & $2 \mathrm{X}$ \\
\hline $\mathrm{MgCl}_{2}$ & $50 \mathrm{mM}$ \\
\hline dNTP & $10 \mathrm{mM}$ \\
\hline Primer F & $1 \mu \mathrm{M}$ \\
\hline Primer R & $1 \mu \mathrm{M}$ \\
\hline Taq & $5 \mathrm{U}$ \\
\hline DNA & $100 \mathrm{ng}$ \\
\hline Agua & - \\
\hline
\end{tabular}




\begin{tabular}{|c|c|c|c|}
\hline Programa & TEMPERATURA & TEMPO & CicLOS \\
\hline Hot-start & $95^{\circ} \mathrm{C}$ & $10^{\prime}$ & \\
\hline Desnaturação & $94^{\circ} \mathrm{C}$ & $30 "$ & 7 \\
\hline Hibridização & $54^{\circ} \mathrm{C}$ & $1^{\prime}$ & 40 ciclos \\
\hline Extensão & $72^{\circ} \mathrm{C}$ & 1 ' & J \\
\hline Extensão final & $72^{\circ} \mathrm{C}$ & $60^{\prime}$ & \\
\hline
\end{tabular}

Quadro 4.4 - Ciclagem padrão utilizada nas reações de PCR

4.2.7.7 Análise de fragmento

Após a PCR, uma quantidade de $1 \mu \mathrm{L}$ do produto de cada amostra foi acrescido de $9 \mu \mathrm{L}$ de formamida HI-DI (altamente deionizada) e de $0,3 \mu \mathrm{L}$ de $\mathrm{LIZ} 600$ e prosseguiu-se a análise de fragmento no sequenciador $A B I 3500$ (Applied Biosystems $^{\mathrm{TM}}$ ). Foi utilizado o software GeneMapper (Applied Biosystems ${ }^{\mathrm{TM}}$ ) para a análise.

4.2.7.8 Análise estatística da Metodologia que utiliza DNA

Os dados obtidos através do uso da Biologia Molecular para amelogenina foram estudados estatisticamente por análise descritiva. 


\section{RESULTADOS}

Todas as medidas obtidas com os métodos antropológicos, bem como os resultados com a análise de DNA estão apresentados no Anexo G.

\subsection{ESTUDO PILOTO}

\subsubsection{Medidas qualitativas: Método de Walker}

Nas Tabelas 5.1 e 5.2 estão apresentados os dados referentes a calibração intra e interexaminador das pesquisadoras para as variáveis qualitativas, através do Índice Kappa.

Tabela 5.1. Distribuição das variáveis qualitativas segundo o indicador Kappa intraexaminador

\begin{tabular}{lccccc}
\hline & $\begin{array}{c}\text { Acerto } \\
(\%)\end{array}$ & Kappa & Std Err & Z & Prob $>\mathbf{Z}$ \\
\hline C. Occip. & 92.86 & 0.90 & 0.17 & 5.32 & $<0.001$ \\
Proc. Mast. & 64.29 & 0.51 & 0.16 & 3.23 & $<0.001$ \\
M. Supraorb. & 71.43 & 0.61 & 0.16 & 3.88 & $<0.001$ \\
Glabela & 92.86 & 0.91 & 0.14 & 6.58 & $<0.001$ \\
Prot. Ment. & 100.00 & 1.00 & 0.14 & 6.44 & $<0.001$ \\
\hline Todas & 84.29 & 0.79 & 0.07 & 11.80 & $<0.001$
\end{tabular}

C. Occip. = Crista occipital externa; Proc. Mastóide = Processo Mastóide; M. Supraorb = Margem Supraorbital; Prot. Ment.= Protuberância Mentual

Tabela 5.2. Distribuição das variáveis qualitativas segundo o indicador Kappa interexaminador

\begin{tabular}{lccccc}
\hline & $\begin{array}{c}\text { Acerto } \\
(\%)\end{array}$ & Kappa & Std Err & Z & \multicolumn{2}{c}{ Prob>Z } \\
\hline C. Occip. & 68.75 & 0.59 & 0.10 & 6.08 & $<0.001$ \\
Proc. Mast. & 71.88 & 0.60 & 0.11 & 5.63 & $<0.001$ \\
M. Supraorb. & 43.75 & 0.21 & 0.10 & 2.16 & $<0.001$ \\
\hline Glabela & 46.88 & 0.33 & 0.09 & 3.79 & $<0.001$ \\
Prot. Ment. & 40.63 & 0.23 & 0.09 & 2.51 & $<0.001$ \\
\hline Todas & 54.37 & 0.40 & 0.04 & 9.26 & $<0.001$
\end{tabular}

C. Occip. = Crista occipital externa; Proc. Mastóide = Processo Mastóide; M. Supraorb = Margem Supraorbital; Prot. Ment.= Protuberância Mentual 


\subsubsection{Medidas quantitativas: Métodos FDB e de Oliveira}

Nas tabelas 5.3 e 5.4 estão apresentados os dados referentes a calibração intra e interexaminador das pesquisadoras para as variáveis quantitativas (Teste $\mathrm{t}$ pareado).

Tabela 5.3 - Distribuição das variáveis quantitativas $(\mathrm{N}=14)$ segundo o teste t para verificar a confiabilidade intraexaminador

\begin{tabular}{|c|c|c|c|c|c|c|}
\hline & \multicolumn{2}{|c|}{ Tempo 1} & \multicolumn{2}{|c|}{ Tempo 2} & \multicolumn{2}{|c|}{ Diferença } \\
\hline & Média & $\overline{D P}$ & Média & DP & Média & $\bar{P}$ \\
\hline g-op & 176.33 & 8.31 & 175.23 & 8.15 & 1.10 & 0.338 \\
\hline eu-eu & 141.15 & 8.06 & 140.90 & 7.98 & 0.25 & 0.338 \\
\hline$z y-z y$ & 126.50 & 6.91 & 125.60 & 7.28 & 0.90 & 0.342 \\
\hline ba-b & 131.64 & 9.13 & 130.67 & 8.75 & 0.97 & 0.325 \\
\hline ba-n & 99.59 & 5.79 & 99.00 & 5.62 & 0.59 & 0.426 \\
\hline ba-pr & 96.83 & 8.37 & 97.08 & 8.75 & -0.25 & 0.463 \\
\hline ecm-ecm & 56.94 & 6.09 & 57.04 & 6.37 & -0.10 & 0.841 \\
\hline pr- alv. & 55.41 & 5.89 & 55.35 & 6.07 & 0.06 & 0.650 \\
\hline AUB & 102.61 & 7.80 & 103.15 & 7.49 & -0.54 & 0.338 \\
\hline n-pr & 64.78 & 5.33 & 65.03 & 5.32 & -0.25 & 0.166 \\
\hline ft-ft & 98.80 & 4.81 & 97.32 & 4.50 & 1.48 & 0.321 \\
\hline fmt-fmt & 98.30 & 5.51 & 97.69 & 5.69 & 0.61 & 0.326 \\
\hline n-ns & 48.07 & 4.22 & 47.80 & 4.29 & 0.27 & 0.165 \\
\hline al-al & 25.94 & 1.78 & 25.62 & 2.00 & 0.32 & 0.379 \\
\hline d-ec D & 39.09 & 4.51 & 39.48 & 2.47 & -0.39 & 0.748 \\
\hline d-ec E & 40.34 & 1.86 & 39.76 & 2.32 & 0.58 & 0.318 \\
\hline OBH D & 34.08 & 2.52 & 33.83 & 2.62 & 0.25 & 0.330 \\
\hline OBH E & 34.14 & 2.95 & 33.88 & 3.08 & 0.26 & 0.400 \\
\hline ec-ec & 90.99 & 18.49 & 89.67 & 18.04 & 1.32 & 0.298 \\
\hline$d-d$ & 21.37 & 2.09 & 21.25 & 1.97 & 0.12 & 0.435 \\
\hline$n-b$ & 108.62 & 6.07 & 114.91 & 23.17 & -6.29 & 0.344 \\
\hline b-I & 111.54 & 7.35 & 111.55 & 7.34 & -0.01 & 0.676 \\
\hline I-O & 95.37 & 6.66 & 95.62 & 6.49 & -0.25 & 0.138 \\
\hline ba-o & 34.67 & 2.89 & 34.69 & 2.97 & -0.02 & 0.847 \\
\hline FOB & 30.42 & 2.80 & 30.34 & 3.00 & 0.08 & 0.527 \\
\hline MDH D & 26.76 & 3.09 & 26.14 & 3.21 & 0.62 & 0.426 \\
\hline MDH E & 27.91 & 2.93 & 27.29 & 3.06 & 0.62 & 0.353 \\
\hline gn-id & 23.65 & 7.47 & 23.16 & 7.51 & 0.49 & 0.325 \\
\hline Alt. FMD & 24.25 & 7.68 & 23.58 & 7.64 & 0.67 & 0.358 \\
\hline Alt. FME & 23.48 & 23.24 & 7.70 & 7.70 & 15.78 & 0.257 \\
\hline Esp MD & 13.12 & 2.42 & 13.22 & 2.44 & -0.10 & 0.044 \\
\hline Esp ME & 12.80 & 12.99 & 1.88 & 1.99 & 10.92 & 0.057 \\
\hline cdl-cdl & 115.00 & 11.20 & 117.00 & 6.77 & -2.00 & 0.323 \\
\hline LmaxRD & 30.15 & 3.00 & 30.35 & 3.07 & -0.20 & 0.022 \\
\hline LmaxRE & 30.26 & 3.32 & 30.54 & 3.29 & -0.28 & 0.152 \\
\hline Ang. MD & 127.07 & 7.36 & 128.38 & 5.73 & -1.31 & 0.327 \\
\hline
\end{tabular}




\begin{tabular}{|c|c|c|c|c|c|c|}
\hline Ang. ME & 127.64 & 7.28 & 128.57 & 6.45 & -0.93 & 0.336 \\
\hline LminRD & 28.64 & 3.67 & 28.53 & 3.46 & 0.11 & 0.365 \\
\hline LminRE & 28.37 & 3.11 & 28.40 & 3.15 & -0.03 & 0.793 \\
\hline Alt.RD & 51.00 & 5.91 & 50.29 & 5.86 & 0.71 & 0.336 \\
\hline Alt. RE & 50.21 & 49.50 & 7.08 & 7.07 & 43.13 & 0.336 \\
\hline
\end{tabular}

Legenda: g-op=Comprimento Máximo do Crânio; eu-eu= Largura Máxima do Crânio (Biéurio); zy-zy= Largura Bizigomática; ba$\mathrm{b}=$ Altura Básio- Bregma; ba-n= Comprimento Básio-Násio; ba-pr= Comprimento Básio-Próstio; ecm-ecm= Máxima Largura Alveolar; pr-alv= Máximo Comprimento Alveolar; $\mathrm{AUB}=$ Largura Biauricular; $\mathrm{n}-\mathrm{pr}=$ Altura Facial Superior; ft-ft= Mínima Largura Frontal; fmt-fmt= Largura Facial Superior; $n-n s=$ Altura Nasal; al-al=Largura Nasal; $d-e c D=$ Largura Orbitária Direita; $d-e c E=$ Largura Orbitária Esquerda; OBHD=Altura Órbita Direita; OBHE=Altura Órbita Esquerda; ec-ec=Largura Biorbitária; $d$-d= Largura Interorbitária; $\mathrm{n}-\mathrm{b}=$ Corda Frontal; $\mathrm{b}-\mathrm{I}=$ Corda Parietal; $\mathrm{I}-\mathrm{o}=$ Corda Occipital; ba- $\mathrm{O}=$ Comprimento do Forame Magno; $\mathrm{FOB}=$ Largura do Forame Magno; $\mathrm{MDHD}=$ Comprimento do Mastoide Direito; MDHE= Comprimento do Mastoide Esquerdo; gn-id= Altura do queixo (gn-id); Alt. FMD= Altura do Corpo da Mandíbula no Forame Magno Direito; Alt. FME= Altura do Corpo da Mandíbula no Forame Magno Esquerdo; Esp MD= Espessura do Corpo da Mandíbula no Forame Magno Direito; Esp ME= Espessura do Corpo da Mandíbula no Forame Magno Esquerdo; cdl-cdl= Largura Bicondilar; LmaxRD= Máxima Largura do Ramo Mandibular Direita; LmaxRE= Máxima Largura do Ramo Mandibular Esquerda; Ang. MD= Ângulo Mandibular Direito; Ang. $\mathrm{ME}=$ Ângulo Mandibular Esquerdo; go-go= Diâmetro Bigonial; LminRD= Largura Mínima do Ramo Mandibular Direito; LminRE= Largura Mínima do Ramo Mandibular Esquerdo; Alt.RD= Máxima Altura do Ramo Mandibular Direito; Alt.RE= Máxima Altura do Ramo Mandibular Esquerdo; CTM= Comprimento Mandibular

Tabela 5.4 - Distribuição das variáveis quantitativas $(\mathrm{N}=32)$ segundo o teste t pareado para verificar a confiabilidade interexaminador

\begin{tabular}{|c|c|c|c|c|c|c|}
\hline & \multicolumn{2}{|c|}{ Examinador 1} & \multicolumn{2}{|c|}{ Examinador 2} & \multicolumn{2}{|c|}{ Diferença } \\
\hline & Média & $\mathrm{DP}$ & Média & DP & Média & $P$ \\
\hline g-op & 176.87 & 8.23 & 177.24 & 8.26 & -0.37 & 0.196 \\
\hline eu-eu & 139.90 & 5.85 & 140.69 & 5.90 & -0.79 & 0.010 \\
\hline zy-zy & 125.44 & 5.97 & 125.71 & 5.96 & -0.27 & 0.012 \\
\hline ba-b & 132.44 & 7.66 & 132.14 & 7.54 & 0.30 & 0.184 \\
\hline ba-n & 99.84 & 5.45 & 99.88 & 5.45 & -0.04 & 0.640 \\
\hline ba-pr & 95.98 & 7.71 & 96.64 & 7.43 & -0.66 & 0.160 \\
\hline ecm-ecm & 55.73 & 6.11 & 56.00 & 5.91 & -0.27 & 0.110 \\
\hline pr- alv. & 53.53 & 4.90 & 52.48 & 4.75 & 1.05 & 0.219 \\
\hline AUB & 100.98 & 6.40 & 99.78 & 5.87 & 1.20 & 0.002 \\
\hline n-pr & 66.56 & 5.40 & 67.00 & 5.77 & -0.44 & 0.085 \\
\hline $\mathrm{ft}-\mathrm{ft}$ & 97.88 & 5.31 & 97.64 & 5.37 & 0.24 & 0.302 \\
\hline fmt-fmt & 97.65 & 5.16 & 96.93 & 5.42 & 0.72 & 0.030 \\
\hline n-ns & 49.55 & 4.63 & 49.13 & 4.91 & 0.42 & 0.101 \\
\hline al-al & 25.01 & 2.34 & 24.80 & 2.44 & 0.21 & 0.094 \\
\hline d-ec D & 38.98 & 3.18 & 40.27 & 1.82 & -1.29 & 0.009 \\
\hline d-ec E & 39.18 & 1.99 & 40.08 & 1.74 & -0.90 & 0.000 \\
\hline OBH D & 36.35 & 10.66 & 35.98 & 9.30 & 0.37 & 0.885 \\
\hline OBH E & 34.18 & 3.66 & 33.04 & 3.92 & 1.14 & 0.209 \\
\hline ec-ec & 92.06 & 12.25 & 93.34 & 12.55 & -1.28 & 0.672 \\
\hline$d-d$ & 20.24 & 3.07 & 20.04 & 3.12 & 0.20 & 0.121 \\
\hline$n-b$ & 112.44 & 16.50 & 110.12 & 4.81 & 2.32 & 0.361 \\
\hline b-I & 110.30 & 6.83 & 110.70 & 7.13 & -0.40 & 0.252 \\
\hline I-0 & 96.00 & 7.54 & 93.57 & 13.40 & 2.43 & 0.251 \\
\hline ba-o & 34.62 & 2.66 & 35.03 & 2.51 & -0.41 & 0.069 \\
\hline FOB & 30.36 & 2.27 & 30.45 & 2.65 & -0.09 & 0.643 \\
\hline MDH D & 27.07 & 3.25 & 26.71 & 3.07 & 0.36 & 0.307 \\
\hline MDH E & 27.52 & 3.15 & 28.11 & 3.01 & -0.59 & 0.041 \\
\hline
\end{tabular}




\begin{tabular}{|c|c|c|c|c|c|c|}
\hline gn-id & 24.61 & 7.12 & 25.23 & 7.38 & -0.62 & 0.304 \\
\hline Alt. FMD & 24.39 & 6.59 & 24.40 & 6.56 & -0.01 & 0.990 \\
\hline Alt. FME & 23.60 & 6.37 & 23.87 & 6.53 & -0.27 & 0.546 \\
\hline Esp ME & 12.21 & 1.73 & 12.15 & 1.78 & 0.06 & 0.723 \\
\hline cdl-cdl & 115.97 & 6.10 & 115.23 & 6.49 & 0.74 & 0.060 \\
\hline LmaxRE & 31.24 & 2.99 & 31.05 & 2.87 & 0.19 & 0.195 \\
\hline Ang. MD & 125.22 & 8.60 & 124.97 & 8.43 & 0.25 & 0.816 \\
\hline Ang. ME & 125.69 & 6.85 & 125.75 & 6.80 & -0.06 & 0.325 \\
\hline go-go & 93.66 & 6.76 & 93.96 & 6.58 & -0.30 & 0.183 \\
\hline Alt.RD & 49.66 & 5.73 & 49.09 & 5.96 & 0.57 & 0.280 \\
\hline Alt. RE & 49.53 & 5.69 & 49.28 & 6.06 & 0.25 & 0.550 \\
\hline CTM & 107.13 & 8.32 & 105.57 & 8.48 & 1.56 & 0.023 \\
\hline
\end{tabular}

Legenda: g-op=Comprimento Máximo do Crânio; eu-eu= Largura Máxima do Crânio (Biéurio); zy-zy= Largura Bizigomática; ba$\mathrm{b}=$ Altura Básio- Bregma; ba- $n=$ Comprimento Básio-Násio; ba-pr= Comprimento Básio-Próstio; ecm-ecm= Máxima Largura Alveolar; pr-alv= Máximo Comprimento Alveolar; $\mathrm{AUB}=$ Largura Biauricular; $\mathrm{n}-\mathrm{pr}=$ Altura Facial Superior; $\mathrm{ft}-\mathrm{ft}=\mathrm{Mínima}$ Largura Frontal; fmt-fmt= Largura Facial Superior; n-ns= Altura Nasal; al-al=Largura Nasal; d-ecD= Largura Orbitária Direita; d-ecE= Largura Orbitária Esquerda; OBHD=Altura Órbita Direita; OBHE=Altura Órbita Esquerda; ec-ec=Largura Biorbitária; d-d= Largura Interorbitária; $\mathrm{n}-\mathrm{b}=$ Corda Frontal; $\mathrm{b}-\mathrm{I}=$ =Corda Parietal; I-o=Corda Occipital; ba-0= Comprimento do Forame Magno; $\mathrm{FOB}=$ Largura do Forame Magno; MDHD= Comprimento do Mastoide Direito; MDHE= Comprimento do Mastoide Esquerdo; gn-id= Altura do queixo (gn-id); Alt. FMD= Altura do Corpo da Mandíbula no Forame Magno Direito; Alt. FME= Altura do Corpo da Mandíbula no Forame Magno Esquerdo; Esp MD= Espessura do Corpo da Mandíbula no Forame Magno Direito; Esp ME= Espessura do Corpo da Mandíbula no Forame Magno Esquerdo; cdl-cdl= Largura Bicondilar; LmaxRD= Máxima Largura do Ramo Mandibular Direita; LmaxRE= Máxima Largura do Ramo Mandibular Esquerda; Ang. MD= Ângulo Mandibular Direito; Ang. $\mathrm{ME}=$ Ângulo Mandibular Esquerdo; go-go= Diâmetro Bigonial; LminRD= Largura Mínima do Ramo Mandibular Direito; LminRE= Largura Mínima do Ramo Mandibular Esquerdo; Alt.RD= Máxima Altura do Ramo Mandibular Direito; Alt.RE= Máxima Altura do Ramo Mandibular Esquerdo; CTM= Comprimento Mandibular

\subsection{RESULTADOS DA ANÁLISE DO MÉTODO DE WALKER}

\subsubsection{Estatística Descritiva}

$\mathrm{Na}$ tabela 5.5 são apresentados os dados dos 66 crânios (34 crânios masculinos e 32 crânios femininos), distribuídos segundo as categorias de 1 a 5 para cada elemento analisado. Os crânios femininos classificaram-se entre as categorias 1,2 e 3, enquanto que a maioria dos crânios masculinos apresentou o índice 3 e 4, com exceção do elemento Protuberância Mentual, que classificou esses crânios entre os escores 2 e 3. 
Tabela 5.5. Distribuição das variáveis qualitativas segundo categorias

\begin{tabular}{|c|c|c|c|c|c|c|c|}
\hline & & \multicolumn{2}{|c|}{ Feminino } & \multicolumn{2}{|c|}{ Masculino } & \multicolumn{2}{|c|}{ Total } \\
\hline & Categoria & $\mathrm{N}$ & $\%$ & $\mathrm{~N}$ & $\%$ & $\mathrm{~N}$ & $\%$ \\
\hline \multirow{5}{*}{$\begin{array}{l}\text { C. Occip. } \\
\left(p=<0,001^{\star}\right)\end{array}$} & 1 & 7 & 21.88 & 1 & 2.94 & 8 & 12.12 \\
\hline & 2 & 15 & 46.88 & 5 & 14.71 & 20 & 30.30 \\
\hline & 3 & 7 & 21.88 & 8 & 23.53 & 15 & 22.73 \\
\hline & 4 & 3 & 9.38 & 13 & 38.24 & 16 & 24.24 \\
\hline & 5 & 0 & 0.00 & 7 & 20.59 & 7 & 10.61 \\
\hline \multirow{5}{*}{$\begin{array}{l}\text { Proc. Mast. } \\
\left(p=<0,001^{\star}\right)\end{array}$} & 1 & 9 & 28.13 & 2 & 5.88 & 11 & 16.67 \\
\hline & 2 & 20 & 62.50 & 4 & 11.76 & 24 & 36.36 \\
\hline & 3 & 2 & 6.25 & 15 & 44.12 & 17 & 25.76 \\
\hline & 4 & 1 & 3.13 & 8 & 23.53 & 9 & 13.64 \\
\hline & 5 & 0 & 0.00 & 5 & 14.71 & 5 & 7.58 \\
\hline \multirow{5}{*}{$\begin{array}{l}\text { M. Supraorb. } \\
\left(p=<0,001^{\star}\right)\end{array}$} & 1 & 8 & 25.00 & 2 & 5.88 & 10 & 15.15 \\
\hline & 2 & 19 & 59.38 & 3 & 8.82 & 22 & 33.33 \\
\hline & 3 & 5 & 15.63 & 18 & 52.94 & 23 & 34.85 \\
\hline & 4 & 0 & 0.00 & 10 & 29.41 & 10 & 15.15 \\
\hline & 5 & 0 & 0.00 & 1 & 2.94 & 1 & 1.52 \\
\hline \multirow{5}{*}{$\begin{array}{c}\text { Glabela } \\
\left(p=<0,001^{\star}\right)\end{array}$} & 1 & 10 & 31.25 & 1 & 2.94 & 11 & 16.67 \\
\hline & 2 & 15 & 46.88 & 2 & 5.88 & 17 & 25.76 \\
\hline & 3 & 6 & 18.75 & 13 & 38.24 & 19 & 28.79 \\
\hline & 4 & 1 & 3.13 & 11 & 32.35 & 12 & 18.18 \\
\hline & 5 & 0 & 0.00 & 7 & 20.59 & 7 & 10.61 \\
\hline \multirow{5}{*}{$\begin{array}{l}\text { Prot. Ment. } \\
\qquad\left(p=<0,001^{\star}\right)\end{array}$} & 1 & 3 & 9.38 & 7 & 20.59 & 3 & 4.55 \\
\hline & 2 & 15 & 46.88 & 12 & 35.29 & 22 & 33.33 \\
\hline & 3 & 12 & 37.50 & 11 & 32.35 & 24 & 36.36 \\
\hline & 4 & 2 & 6.25 & 4 & 11.76 & 13 & 19.70 \\
\hline & 5 & 0 & 0.00 & 0 & 0.00 & 4 & 6.06 \\
\hline
\end{tabular}

C. Occip. = Crista occipital externa; Proc. Mastóide = Processo Mastóide; M. Supraorb = Margem Supraorbital; Prot. Ment.= Protuberância Mentual

Na tabela 5.6 são apresentados os dados dos elementos analisados nos 66 crânios (34 crânios masculinos e 32 crânios femininos), que resumem as informações obtidas e, traçam um perfil das variáveis qualitativas utilizadas no estudo (Média e Desvio Padrão).

Tabela 5.6 Média e desvio padrão das variáveis qualitativas segundo categorias

\begin{tabular}{lllllll}
\hline & \multicolumn{2}{c}{ Masculino } & \multicolumn{2}{c}{ Feminino } & \multicolumn{2}{c}{ Diferença } \\
\hline & Média & DP & Média & DP & Média & $\mathrm{P}$ \\
C.Occip. & 3.59 & 1.07 & 2.19 & 0.89 & -1.40 & $\mathrm{p}=<0.001$ \\
Proc. Mast. & 3.30 & 1.06 & 1.84 & 0.68 & -1.45 & $\mathrm{p}=<0.001$ \\
M. Supra-orb. & 3.14 & 0.86 & 1.90 & 0.64 & -1.24 & $\mathrm{p}=<0.001$ \\
Glabela & 3.62 & 0.99 & 1.93 & 0.80 & -1.68 & $\mathrm{p}=<0.001$ \\
Em. Ment. & 3.35 & 0.94 & 2.40 & 0.76 & -0.95 & $\mathrm{p}=<0.001$
\end{tabular}

C. Occip. = Crista occipital externa; Proc. Mastóide = Processo Mastóide; M. Supraorb = Margem Supraorbital; Prot. Ment.= Protuberância Mentual 


\subsubsection{Análise Discriminante Linear}

$\mathrm{Na}$ tabela 5.7 estão apresentadas as porcentagens de acerto dos elementos visuais analisados na determinação do sexo, segundo análise discriminante linear.

Tabela 5.7 - Resultado da análise discriminante aplicando a análise discriminante linear para determinação do sexo utilizando várias combinações de variáveis independentes para as variáveis qualitativas

\begin{tabular}{|c|c|c|c|}
\hline Modelo & Masc(\%) & Fem(\%) & Diff(\%) \\
\hline Sex = C. Occip. & 82.35 & 68,75 & 13,6 \\
\hline Sex = Proc. Mast. & 82,35 & 90,63 & -8.28 \\
\hline Sex = M. Supraorb. & 85.29 & 84.38 & 0.91 \\
\hline Sex = Glabela & 91.18 & 78.13 & 13.05 \\
\hline Sex = Em. Ment. & 79.41 & 56.25 & 23.16 \\
\hline Sex = C. Occip. + Proc. Mast. & 73.53 & 87.50 & -13.97 \\
\hline Sex = C. Occip. + M. Supraorb. & 82.35 & 87.50 & -5.15 \\
\hline Sex = C. Occip. + Supraorb/ Glab. & 82.35 & 84.38 & -2.03 \\
\hline Sex = C. Occip. + Em. Ment. & 73.53 & 81.25 & -7.72 \\
\hline Sex = Proc. Mast. + M. Supraorb. & 79.41 & 96.88 & -17.47 \\
\hline Sex $=$ Proc. Mast. + M. Supraorb $/$ Glab. & 85.29 & 93.75 & -8.46 \\
\hline Sex $=$ Proc. Mast. + Em. Ment. & 82.35 & 93.75 & -11.4 \\
\hline Sex = M. S. Orb.+ Supraorb/ Glab. & 88.24 & 87.50 & 0.74 \\
\hline Sex = M. S. Orb. + Em. Ment. & 88.24 & 84.38 & 3.86 \\
\hline Sex = Glab. + Em. Ment. & 82.35 & 84.38 & -2.03 \\
\hline Sex = C. Occip. + Proc. Mast. + M. Supraorb. & 85.29 & 90.63 & -5.34 \\
\hline Sex = C. Occip. + M. Supraorb. + Supraorb/ Glab. & 85.29 & 90.63 & -5.34 \\
\hline Sex = C. Occip. + Proc. Mast. + Em. Ment. & 73.53 & 93.75 & -20.22 \\
\hline Sex = C. Occip. + M. Supraorb. + Supraorb/ Glab. & 88.24 & 84.38 & 3.86 \\
\hline Sex = C. Occip. + M. Supraorb. + Em. Ment. & 88.24 & 84.38 & 3.86 \\
\hline Sex = C. Occip. + Supraorb/Glab. + Em. Ment. & 82.35 & 81.25 & 1.1 \\
\hline Sex = Proc. Mast. + M. Supraorb. + M. Supraorb/ Glab. & 85.29 & 93.75 & -8.46 \\
\hline Sex = Proc. Mast. + M. Supraorb. + Em. Ment. & 82.35 & 87.50 & -5.15 \\
\hline Sex = M. Supraorb. + Supraorb/ Glab. + Em. Ment. & 88.24 & 87.50 & 0.74 \\
\hline Sex = C. Occip. + Proc. Mast. + M. Supraorb. + M. Supraorb/ Glab. & 88.24 & 87.50 & 0.74 \\
\hline Sex = C. Occip. + Proc. Mast. + M. Supraorb. + Em. Ment. & 85.29 & 90.63 & -5.34 \\
\hline Sex = Proc. Mast. + M. Supraorb. + M. Supraorb./Glab. + Em. Ment. & 85.29 & 87.50 & -2.21 \\
\hline $\begin{array}{l}\text { Sex = C. Occip. + Proc. Mast. + M. Supraorb. + M. Supraorb/ Glab. + Em } \\
\text { Ment. }\end{array}$ & 85.29 & 87.50 & -2.21 \\
\hline
\end{tabular}

Pela Análise discriminante linear, o elemento Processo mastóide mostrou ser, isoladamente, o melhor discriminante para o sexo, com $82,35 \%$ de acerto para 
masculino e 90,63\% para feminino. Combinando-se esse elemento (processo mastóide) com a Margem Supraorbital/ glabela, o acerto foi de 85,29\% para homem e 93,75\% para mulher. Somando-se a esses dois caracteres o elemento Margem Supraorbital, a porcentagem foi de $85,29 \%$ para sexo masculino e $93,75 \%$ para feminino. E, finalmente, quando se analisam as características Crista occipital externa, Processo mastóide, Margem Supraorbital e Protuberância mentual, a acurácia obtida foi de $85,29 \%$ para homens e $90,63 \%$ para mulheres.

\subsubsection{Análise Discriminante Logística}

$\mathrm{Na}$ tabela 5.8 estão apresentadas as porcentagens de acerto dos elementos analisados na determinação do sexo, segundo análise discriminante logística.

Tabela 5.8 - Resultado da análise discriminante utilizando a análise discriminante logística para a determinação do sexo utilizando várias combinações de variáveis independentes para as variáveis qualitativas

\begin{tabular}{|c|c|c|c|}
\hline Modelo & Masc(\%) & Fem(\%) & Diff(\%) \\
\hline Sex = C. Nucal & 82.35 & 68.75 & 13.6 \\
\hline Sex = Proc. Mast. & 82.35 & 90.63 & -8.28 \\
\hline Sex = M. Supraorb. & 85.29 & 84.38 & 0.91 \\
\hline Sex = Supraorb./ Glab. & 91.18 & 78.13 & 13.05 \\
\hline Sex $=$ Em. Ment. & 79.41 & 56.25 & 23.16 \\
\hline Sex = C. Occip. + Proc. Mast. & 82.35 & 84.38 & -2.03 \\
\hline Sex = C. Occip. + M. Supraorb. & 88.24 & 81.25 & 6.99 \\
\hline Sex = C. Occip. + Supraorb/ Glab. & 82.35 & 84.38 & -2.03 \\
\hline Sex = C. Occip. + Em. Ment. & 73.53 & 78.13 & -4.6 \\
\hline Sex = Proc. Mast. + M. Supraorb. & 88.24 & 81.25 & 6.99 \\
\hline Sex = Proc. Mast. +Supraorb/ Glab. & 85.29 & 93.75 & -8.46 \\
\hline Sex = Proc. Mast. + Em. Ment. & 82.35 & 90.63 & -8.28 \\
\hline Sex = M. S. Orb.+ Supraorb/ Glab. & 88.24 & 87.5 & 0.74 \\
\hline Sex = M. S. Orb. + Em. Ment. & 88.24 & 84.38 & 3.86 \\
\hline Sex = Glab. + Em. Ment. & 82.35 & 84.38 & -2.03 \\
\hline Sex = C. Occip. + Proc. Mast. + M. Supraorb. & 88.24 & 87.5 & 0.74 \\
\hline Sex = C. Occip. + M. Supraorb. + Supraorb/ Glab. & 85.29 & 90.63 & -5.34 \\
\hline Sex = C. Occip. + Proc. Mast. + Em. Ment. & 79.41 & 87.5 & -8.09 \\
\hline Sex = C. Occip. + M. Supraorb. + Supraorb/ Glab. & 85.29 & 81.25 & 4.04 \\
\hline Sex = C. Occip. + M. Supraorb. + Em. Ment. & 88.24 & 84.38 & 3.86 \\
\hline Sex = C. Occip. + Supraorb/Glab. + Em. Ment. & 82.35 & 81.25 & 1.1 \\
\hline Sex = Proc. Mast. + M. Supraorb. + Supraorb/ Glab. & 85.29 & 93.75 & -8.46 \\
\hline Sex = Proc. Mast. + M. Supraorb. + Em. Ment. & 82.35 & 84.38 & -2.03 \\
\hline Sex = M. Supraorb. + Supraorb/ Glab. + Em. Ment. & 88.24 & 87.5 & 0.74 \\
\hline
\end{tabular}




\begin{tabular}{|c|c|c|c|}
\hline Sex = C. Occip. + Proc. Mast. + M. Supraorb. + Supraorb/ Glab. & 85.29 & 90.63 & -5.34 \\
\hline Sex = C. Occip. + Proc. Mast. + M. Supraorb. + Em. Ment. & 85.29 & 87.5 & -2.21 \\
\hline Sex = Proc. Mast. + M. Supraorb. + Supraorb./Glab. + Em. Ment. & 85.29 & 93.75 & -8.46 \\
\hline $\begin{array}{l}\text { Sex }=\text { C. Occip. + Proc. Mast. + M. Supraorb. + Supraorb/ Glab. + Em } \\
\text { Ment. }\end{array}$ & 85.29 & 90.63 & -5.34 \\
\hline Sex= M. Supraorb/Glabela + Proc. Mast. + Emin. Mentual (Walker) & 88.24 & 81.25 & 6.99 \\
\hline
\end{tabular}

Pela Análise discriminante logística, os melhores resultados foram obtidos nas seguintes combinações: Processo mastóide com Margem Supraorbital/ glabela, o acerto foi de $85,29 \%$ para homem e $93,75 \%$ para mulher. Somando-se a esses dois caracteres o elemento Margem Supraorbital, a porcentagem foi de $85,29 \%$ para sexo masculino e $93,75 \%$ para feminino. $E$, finalmente, quando se analisam as quatro características Processo mastóide, Margem Supraorbital, Supraobrital/glabela e Protuberância Mentual, a acurácia obtida foi de $85,29 \%$ para homens e 93,75\% para mulheres.

\subsubsection{Regressao Logística}

A regressão logística é uma técnica que permite a criação de uma fórmula para ser utilizada na determinação do sexo. Foram construídas algumas funções, que possuem um ponto de corte que indica a logito. Esse logito permitirá a definição da probabilidade de pertinência de um esqueleto pertencer ao sexo masculino ou feminino. As funções estão indicadas na tabela 5.9. 
Tabela 5.9 - Equação da análise logística para a determinação do sexo utilizando diferentes combinações das variáveis independentes para as variáveis qualitativas

\begin{tabular}{|c|c|c|}
\hline Model & Equação & $\mathbf{P}$ \\
\hline Sex = C. Occip. & $\mathrm{S}=-3.69+$ C.Nucal $^{*} 1.31$ & $p=<0.001$ \\
\hline Sex =Proc. Mast. & $\mathrm{S}=-4.68+$ Mast. $^{*} 1.91$ & $p=<0.001$ \\
\hline Sex = M. Supraorb. & $S=-5.27+$ M. Orb. ${ }^{*} 2.11$ & $\mathrm{p}=<0.001$ \\
\hline Sex = Supraorb./ Glab. & $S=-5.42+$ Glab. ${ }^{*} 2.00$ & $p=<0.001$ \\
\hline Sex $=$ Em. Ment. & $S=-3.63+$ Em. Ment. * 1.3 & $p=<0.001$ \\
\hline Sex = C. Occip. + Proc. Mast. & $S=-6.38+$ C. Occip. ${ }^{*} 0.94+$ Mast. ${ }^{*} 1.54$ & $\mathrm{p}=<0.001$ \\
\hline Sex= C. Occip. + M. Supraorb. & $\mathrm{S}=-6.17+$ C. Occip. ${ }^{*} 0.83+$ M. Orb. ${ }^{*} 1.54$ & $p=<0.001$ \\
\hline Sex = C. Occip. + Supraorb./ Glab. & $\mathrm{S}=-7.01+$ C. Occip. ${ }^{*} 0.85+$ Glab. ${ }^{*} 1.67$ & $p=<0.001$ \\
\hline Sex = C. Occip. + Em. Ment. & $\begin{array}{l}S=-5.37+\text { C. Occip. }{ }^{*} 1.07+\text { Em. Ment. }{ }^{*} \\
0.84\end{array}$ & $\mathrm{p}=<0.001$ \\
\hline Sex = Proc. Mast. + M.Supraorb. & $S=-6.80+$ Mast. $^{*} 1.41+$ M. Orb. ${ }^{*} 1.37$ & $\mathrm{p}=<0.001$ \\
\hline Sex = Proc. Mast. + Supraorb./ Glab. & $\mathrm{S}=-7.74+$ Mast. ${ }^{*} 1.45+$ Glab. ${ }^{*} 1.51$ & $\mathrm{p}=<0.001$ \\
\hline Sex $=$ Proc. Mast. + Em.Ment. & $S=-5.87+$ Mast. ${ }^{*} 1.63+$ Em. Ment. ${ }^{*} 0.67$ & $\mathrm{p}=<0.001$ \\
\hline Sex = M. Supraorb. + Supraorb./ Glab. & $\mathrm{S}=-6.04+$ M. Orb. ${ }^{*} 0.89+$ Glab. ${ }^{*} 1.40$ & $\mathrm{p}=<0.001$ \\
\hline Sex = M. Supraorb. + Em. Ment. & $\mathrm{S}=-6.65+$ M. Orb. ${ }^{*} 1.83+$ Em. Ment. ${ }^{*} 0.72$ & $\mathrm{p}=<0.001$ \\
\hline Sex = Supraorb./ Glab. + Em. Ment. & $S=-6.51+$ Glab. ${ }^{*} 1.74+$ Em. Ment. ${ }^{*} 0.65$ & $p=<0.001$ \\
\hline Sex = C. Occip. + Proc. Mast. + M. Supraorb. & $\begin{array}{l}S=-7.31+\text { C. Occip. }{ }^{*} 0.64+\text { Mast. }^{*} 1.28+ \\
\text { M. Orb. }{ }^{*} 0.98\end{array}$ & $p=<0.001$ \\
\hline Sex = C. Occip. + Proc. Mast. + Supraorb./Glab. & $\begin{array}{l}\mathrm{S}=-8.30+\text { C. Occip. }{ }^{*} 0.55+\text { Mast. }{ }^{*} 1.25+ \\
\text { Glab. }{ }^{*} 1.31\end{array}$ & $p=<0.001$ \\
\hline Sex = C. Occip. + Proc. Mast. + Em. Ment. & $\begin{array}{l}S=-7.07+\text { C. Occip. }{ }^{*} 0.87+\text { Mast. }{ }^{*} 1.42+ \\
\text { Em. Ment. }{ }^{*} 0.44\end{array}$ & $\mathrm{p}=<0.001$ \\
\hline Sex = C. Occip. + M. Supraorb. + Supraorb./Glab. & $\begin{array}{l}\mathrm{S}=-7.11+\text { C. Occip. }{ }^{*} 0.73+\text { M. Orb. }{ }^{*} 0.53+ \\
\text { Glab. }{ }^{*} 1.34\end{array}$ & $p=<0.001$ \\
\hline Sex = C. Occip. + M. Supraorb. + Em. Ment. & $\begin{array}{l}\mathrm{S}=-7.00+\text { C. Occip. }{ }^{*} 0.72+\text { M. Orb. }{ }^{*} 1.42+ \\
\text { Em. Ment. }{ }^{*} 0.51\end{array}$ & $p=<0.001$ \\
\hline Sex = C. Occip. + Supraorb./ Glab. + Em. Ment. & $\begin{array}{l}\mathrm{S}=-7.30+\text { C. Occip. }{ }^{*} 0.76+\text { Glab. }{ }^{*} 1.56+ \\
\text { Em. Ment. }{ }^{*} 0.31\end{array}$ & $p=<0.001$ \\
\hline Sex = Proc. Mast. + M. Supraorb. + Supraorb./ Glab. & $\begin{array}{l}S=-7.72+\text { Mast. }{ }^{*} 1.41+\text { M. Orb. }{ }^{*} 0.17+ \\
\text { Glab. }{ }^{*} 1.40\end{array}$ & $\mathrm{p}=<0.001$ \\
\hline Sex = Proc. Mast. + M. Supraorb. + Em. Ment. & $\begin{array}{l}\mathrm{S}=-7.15+\text { Mast. }{ }^{*} 1.28+\text { M. Orb. }{ }^{*} 1.29+ \\
\text { Em. Ment. }{ }^{*} 0.31\end{array}$ & $\mathrm{p}=<0.001$ \\
\hline Sex = M. Supraorb. + Supraorb./ Glab. + Em. Ment. & $\begin{array}{l}\mathrm{S}=-6.79+\mathrm{M} . \text { Orb. }{ }^{*} 0.75+\text { Glab. }{ }^{*} 1.30+ \\
\text { Em. Ment. }{ }^{*} 0.48\end{array}$ & $\mathrm{p}=<0.001$ \\
\hline $\begin{array}{l}\text { Sex = C. Occip. + Proc. Mast. + M. Supraorb. + } \\
\text { Supraorb./ Glab. }\end{array}$ & $\begin{array}{l}S=-8.34+\text { C. Occip. }{ }^{*} 0.57+\text { Mast. }{ }^{*} 1.28+ \\
\text { M. Orb * }\end{array}$ & $p=<0.001$ \\
\hline Sex = C. Occip. + Proc. Mast. + M. Supraorb.+ Em. Ment. & $\begin{array}{l}S=-7.64+\text { C. Occip. }{ }^{*} 0.62+\text { Mast. }{ }^{*} 1.20+ \\
\text { M. Orb. }{ }^{*} 0.93+\text { Em. Ment. }{ }^{*} 0.26\end{array}$ & $p=<0.001$ \\
\hline $\begin{array}{l}\text { Sex = Proc. Mast. + M. Supraorb. + Supraorb. /Glab. + } \\
\text { Em. Ment. }\end{array}$ & $\begin{array}{l}S=-7.87+\text { Mast. }{ }^{*} 1.35+\text { M. Orb. }{ }^{*} 0.12+ \\
\text { Glab. }{ }^{*} 1.39+\text { Em. Ment. }{ }^{*} 0.15\end{array}$ & $p=<0.001$ \\
\hline $\begin{array}{l}\text { Sex = C. Occip. + Proc. Mast. + M. Supraorb. + } \\
\text { Supraorb./ Glab. + Em Ment. }\end{array}$ & $\begin{array}{l}S=-8.38+\text { C. Occip. }{ }^{*} 0.57+\text { Mast. }^{*} 1.27+ \\
\text { M. Orb. }{ }^{*}-0.12\end{array}$ & $\mathrm{p}=<0.001$ \\
\hline $\begin{array}{l}\text { Sex= M. Supraorb/Glabela + Proc. Mast. + Emin. Mentual } \\
\text { (Walker) }\end{array}$ & $\begin{array}{l}S=\text { Glabela }^{*}-1.37+\text { Proc. Mast. }{ }^{*}-1.18+ \\
\text { Em. Ment. }{ }^{*}-1.15+9.128\end{array}$ & \\
\hline
\end{tabular}


Para a regressão logística, as equações que ofereceram os melhores resultados para ambos os sexos (acerto de $89,52 \%$ ) foram três, sendo a primeira com os elementos processo mastóide e glabela, a segunda, com três variáveis, que são o processo mastóide, a glabela e a Protuberância Mentual e, a última, com quatro elementos, o processo mastóide, a Crista occipital externa, a margem supraorbital e a protuberância mentual. As fórmulas são as seguintes:

$\mathrm{S}($ Logito) $=-7.74+$ Processo Mastóide $\times 1.45+$ Glabela $\times 1.51$

$\mathrm{S}$ (Logito) $=-7.15+$ Processo Mastóide $\times 1.28+$ Margem supraorbital $\times 1.29+$ Protuberância Mentual x 0.31

$S($ Logito $)=-7.87+$ Crista occipital $\times 0.62+$ Mastóide $\times 1.20+$ Margem Supraorbitária $\times 0.93+$ Protuberância Mentual x 0.15

Apartir dessas fórmulas, obtem-se o valor do logito. A probabilidade de ser do sexo feminino (PF) e do masculino (PM) pode ser calculada segundo as equações:

$P F=1 /\left(1+e^{- \text {logito }}\right)$
$P M=1-P F$

\subsection{RESULTADOS DA ANÁLISE DO MÉTODO DO FDB}

\subsubsection{Estatística Descritiva}

Na tabela 5.10 são apresentados os dados das medições nos 66 crânios (34 crânios masculinos e 32 crânios femininos), que resumem as informações obtidas e, 
traçam um perfil das variáveis qualitativas utilizadas no estudo (Média e Desvio Padrão), bem como mostram o intervalo de confiança para cada medida, dividido por sexo.

Tabela 5.10 - Média, desvio padrão e intervalo de confiança das variáveis quantitativas segundo categorias

\begin{tabular}{|c|c|c|c|c|c|c|c|c|}
\hline & \multicolumn{2}{|c|}{ Masculino } & \multicolumn{4}{|c|}{ Feminino } & \multicolumn{2}{|c|}{ Diferença } \\
\hline & Média $(\mathrm{mm})$ & DP & IC (95\%) & Média (mm) & DP & IC (95\%) & Média & $\bar{P}$ \\
\hline g-op & 181.91 & 7.28 & 180.47- 183.35 & 171.48 & 6.30 & $170.23-172.73$ & -10.43 & 0.000 \\
\hline eu-eu & 141.62 & 6.22 & $140.39-142.85$ & 136.26 & 7.17 & $134.84-137.68$ & -5.36 & 0.002 \\
\hline$z y-z y$ & 129.16 & 5.70 & $128.13-130.29$ & 121.10 & 4.35 & $120.23-121.95$ & -8.07 & 0.000 \\
\hline ba-b & 135.56 & 7.21 & $134.12-136.98$ & 127.72 & 6.95 & $126.35-129.11$ & -7.82 & 0.000 \\
\hline ba-n & 102.40 & 5.12 & $101.91-104.57$ & 95.70 & 4.34 & $94.81-96.54$ & -6.71 & 0.000 \\
\hline ba-pr & 99.22 & 8.55 & $97.52-100.90$ & 93.53 & 5.32 & $92.47-94.59$ & -5.68 & 0.115 \\
\hline ecm-ecm & 58.38 & 7.13 & 56.97-59.79 & 54.29 & 5.90 & $53.13-55.47$ & -4.08 & 0.022 \\
\hline pr- alv. & 56.14 & 4.80 & $56.51-61.74$ & 53.10 & 4.91 & $52.12-54.08$ & -3.03 & 0.205 \\
\hline AUB & 102.1 & 6.34 & $100.67-103.21$ & 97.03 & 4.16 & $96.20-97.85$ & -5.10 & 0.000 \\
\hline n-pr & 68.19 & 5.39 & 68.07-71.79 & 64.08 & 3.02 & $63.49-68.69$ & -4.10 & 0.070 \\
\hline ft-ft & 98.75 & 4.48 & $98.86-100.64$ & 95.99 & 5.35 & $94.93-97.05$ & -3.76 & 0.003 \\
\hline fmt-fmt & 98.74 & 4.41 & $95.45-99$ & 96.54 & 5.33 & $95.48-97.60$ & -2.20 & 0.781 \\
\hline n-ns & 51.17 & 3.13 & $49.05-51.28$ & 46.25 & 3.04 & $45.65-46.85$ & -4.92 & 0.000 \\
\hline al-al & 24.94 & 2.29 & $24.66-26$ & 25.96 & 2.01 & $24.56-25.36$ & 0.02 & 0.975 \\
\hline d-ec D & 40.21 & 1.46 & $39.91-40.49$ & 38.93 & 2.02 & $37.80-39.08$ & -1.28 & 0.005 \\
\hline d-ec E & 40.15 & 1.56 & $39.59-40.37$ & 38.85 & 2.03 & $38.45-39.25$ & -1.30 & 0.007 \\
\hline OBH D & 34.12 & 2.24 & $33.76-37.84$ & 34.10 & 2.53 & $33.60-34.60$ & -0.03 & 0.962 \\
\hline OBH E & 34.63 & 2.27 & $33.74-38.49$ & 33.90 & 2.41 & $33.42-34.38$ & -0.72 & 0.225 \\
\hline ec-ec & 95.32 & 4.96 & $90.28-95.68$ & 94.11 & 4.32 & $89.67-94.53$ & -1.21 & 0.309 \\
\hline d-d & 20.38 & 3.05 & $19.86-26.69$ & 21.69 & 2.52 & $21.19-22.19$ & 1.30 & 0.076 \\
\hline$n-b$ & 111.70 & 5.43 & $110.79-117.10$ & 107.75 & 4.64 & $106.82-108.67$ & -3.95 & 0.002 \\
\hline b-I & 113.21 & 7.55 & $111.69-114.73$ & 108.31 & 5.57 & $107.19-109.40$ & -4.91 & 0.007 \\
\hline I-O & 97.44 & 6.25 & $96.20-98.68$ & 92.22 & 5.54 & $91.11-93.31$ & -5.23 & 0.001 \\
\hline ba-o & 35.36 & 2.46 & $34.87-35.85$ & 33.61 & 2.57 & $33.10-34.12$ & -1.75 & 0.006 \\
\hline FOB & 30.64 & 2.43 & $30.16-31.12$ & 28.91 & 2.24 & 28.45-29.35 & -1.74 & 0.004 \\
\hline MDH D & 28.47 & 3.49 & $27.78-29.16$ & 25.54 & 3.11 & $24.92-26.16$ & -2.93 & 0.001 \\
\hline MDH E & 28.98 & 2.91 & $28.40-29.08$ & 25.89 & 2.65 & $25.36-26.41$ & -3.09 & 0.001 \\
\hline gn-id & 27.82 & 6.33 & $26.56-29.08$ & 22.35 & 6.68 & 21.02-23.67 & -5.47 & 0.001 \\
\hline Alt. FMD & 26.81 & 5.76 & 25.67-27.95 & 22.09 & 5.99 & 20.91-23.29 & -4.71 & 0.002 \\
\hline Alt. FME & 26.09 & 5.91 & $24.92-27.26$ & 21.53 & 5.79 & $20.38-22.68$ & -4.56 & 0.002 \\
\hline Esp MD & 13.20 & 2.42 & $12.72-13.86$ & 12.06 & 1.78 & $11.71-12.41$ & -1.15 & 0.032 \\
\hline Esp ME & 12.88 & 2.12 & $12.46-13.30$ & 12.05 & 1.64 & $11.72-12.38$ & -0.83 & 0.083 \\
\hline cdl-cdl & 117.42 & 6.86 & $116.06-118.78$ & 111.36 & 6.86 & $110.03-112.69$ & -6.06 & 0.001 \\
\hline LmaxRD & 31.66 & 3.56 & $31.15-32.65$ & 29.74 & 2.67 & 29.21-30.27 & -1.92 & 0.017 \\
\hline LmaxRE & 32.53 & 3.92 & $31.75-33.31$ & 30.38 & 2.65 & $29.85-30.90$ & -2.15 & 0.012 \\
\hline Ang. MD & 123.09 & 7.93 & $121.51-124.66$ & 127.62 & 8.57 & $125.93-129.33$ & 4.54 & 0.029 \\
\hline Ang. ME & 123.23 & 7.55 & $121.73-124.73$ & 127.61 & 6.18 & $126.39-128.84$ & 4.39 & 0.013 \\
\hline go-go & 96.91 & 5.34 & $88.82-90.94$ & 89.88 & 6.09 & $95.70-98.12$ & -7.03 & 0.000 \\
\hline LminRD & 29.88 & 4.06 & $27.56-28.66$ & 28.11 & 2.78 & 28.96-30.57 & -1.76 & 0.045 \\
\hline LminRE & 30.48 & 3.99 & $28.04-29.06$ & 28.55 & 2.56 & $29.68-31.65$ & -1.92 & 0.023 \\
\hline
\end{tabular}




\begin{tabular}{lcccccccc}
\hline Alt.RD & 51.47 & 5.97 & $46.31-48.01$ & 47.16 & 4.30 & $50.28-52.65$ & -4.31 & 0.001 \\
Alt. RE & 51.41 & 6.22 & $46.01-47.31$ & 46.66 & 3.27 & $50.18-52.64$ & -4.75 & 0.000 \\
CTM & 107.86 & 6.45 & $102.90-105.72$ & 104.31 & 7.09 & $106.58-109.14$ & -3.55 & 0.037 \\
\hline
\end{tabular}

Legenda: g-op=Comprimento Máximo do Crânio; eu-eu= Largura Máxima do Crânio (Biéurio); zy-zy= Largura Bizigomática; ba$\mathrm{b}=$ Altura Básio- Bregma; ba- $n=$ Comprimento Básio-Násio; ba-pr= Comprimento Básio-Próstio; ecm-ecm= Máxima Largura Alveolar; pr-alv= Máximo Comprimento Alveolar; AUB= Largura Biauricular; n-pr= Altura Facial Superior; ft-ft= Mínima Largura Frontal; fmt-fmt= Largura Facial Superior; $n-n s=$ Altura Nasal; al-al=Largura Nasal; $d-e c D=$ Largura Orbitária Direita; $d$-ecE= Largura Orbitária Esquerda; OBHD=Altura Órbita Direita; OBHE=Altura Órbita Esquerda; ec-ec=Largura Biorbitária; $d$-d= Largura Interorbitária; $\mathrm{n}-\mathrm{b}=$ Corda Frontal; $\mathrm{b}-\mathrm{I}=$ Corda Parietal; $\mathrm{I}-\mathrm{o}=$ Corda Occipital; ba- $\mathrm{o}=$ Comprimento do Forame Magno; $\mathrm{FOB}=$ Largura do Forame Magno; $\mathrm{MDHD}=$ Comprimento do Mastoide Direito; MDHE= Comprimento do Mastoide Esquerdo; gn-id= Altura do queixo (gn-id); Alt. FMD= Altura do Corpo da Mandíbula no Forame Magno Direito; Alt. FME= Altura do Corpo da Mandíbula no Forame Magno Esquerdo; Esp MD= Espessura do Corpo da Mandíbula no Forame Magno Direito; Esp ME= Espessura do Corpo da Mandíbula no Forame Magno Esquerdo; cdl-cdl= Largura Bicondilar; LmaxRD= Máxima Largura do Ramo Mandibular Direita; LmaxRE= Máxima Largura do Ramo Mandibular Esquerda; Ang. MD= Ângulo Mandibular Direito; Ang. $\mathrm{ME}=$ Ângulo Mandibular Esquerdo; go-go= Diâmetro Bigonial; LminRD= Largura Mínima do Ramo Mandibular Direito; LminRE= Largura Mínima do Ramo Mandibular Esquerdo; Alt.RD= Máxima Altura do Ramo Mandibular Direito; Alt.RE= Máxima Altura do Ramo Mandibular Esquerdo; CTM= Comprimento Mandibular

Com exceção das medidas Largura Nasal (al-al), Largura interorbitária (d-d) e Ângulo Mandibular (Ang.M), todas as outras medidas apresentaram a maior média para o sexo masculino. A maioria das medidas resultaram em diferença estatísticamente significante entre os sexos, confirmado pelo valor de $p<0,05$, excetuando-se as mensurações Largura Nasal (al-al), Máximo Comprimento Alveolar (pr-alv), Altura Facial Superior (n-pr), Largura Facial Superior (fmt-fmt), Altura da Órbita $(\mathrm{OBH})$, Largura da Órbita (d-ec), Largura Biorbitária (ec-ec) e Espessura Mandibular (Esp. M).

Ainda nessas tabelas, pode-se observar pelo desvio padrão que a variação dentro do sexo masculino é semelhante ás variações das observações dentro do sexo feminino, indicando que os erros cometidos na obtenção dos dados não foram maiores em um sexo em relação ao outro.

\subsubsection{Análise Discriminante Linear}

A tabela 5.11 mostra o índice de acerto de cada medida para os sexos masculino e feminino. 
Tabela 5.11 - Resultado da análise discriminante utilizando a análise discriminante linear para a determinação do sexo utilizando várias combinações de variáveis independentes para as medições

\begin{tabular}{|c|c|c|c|}
\hline Modelo & Masc(\%) & Fem(\%) & Diff(\%) \\
\hline Sex = g-po & 70.59 & 81.25 & -10.66 \\
\hline Sex = eu-eu & 70.59 & 71.88 & -1.29 \\
\hline Sex = zy-zy & 74.19 & 80.00 & -5.81 \\
\hline Sex = ba-b & 73.53 & 75.00 & -1.47 \\
\hline Sex = ba-n & 73.53 & 78.13 & -4.60 \\
\hline Sex = ba-pr & 52.63 & 71.43 & -18.80 \\
\hline Sex = ecm-ecm & 62.07 & 57.14 & 4.93 \\
\hline Sex = pr-alv & 58.82 & 83.33 & -24.51 \\
\hline Sex = AUB & 54.84 & 70.97 & -16.13 \\
\hline Sex = n-pr & 60.00 & 85.71 & -25.71 \\
\hline Sex = ft-ft & 58.82 & 67.74 & -8.92 \\
\hline Sex = fmt-fmt & 63.64 & 50.00 & 13.64 \\
\hline Sex $=n-n s$ & 77.78 & 73.08 & 4.70 \\
\hline Sex = al-al & 46.88 & 50.00 & -3.12 \\
\hline Sex $=d-e c D$ & 72.73 & 51.72 & 21.01 \\
\hline Sex = d-ec E & 70.97 & 61.29 & 9.68 \\
\hline Sex = OBH D & 38.24 & 72.41 & -34.17 \\
\hline Sex = OBH E & 43.75 & 70.97 & -27.22 \\
\hline Sex = ec-ec & 68.75 & 36.67 & 32.08 \\
\hline Sex = d-d & 28.13 & 62.07 & -33.94 \\
\hline Sex $=n-b$ & 52.94 & 75.00 & -22.06 \\
\hline Sex = b-I & 66.67 & 73.08 & -6.41 \\
\hline Sex = I-0 & 73.53 & 73.08 & 0.45 \\
\hline Sex = ba-o & 64.71 & 65.63 & -0.92 \\
\hline Sex $=$ FOB & 61.76 & 65.63 & -3.87 \\
\hline Sex = MDH D & 51.52 & 68.75 & -17.23 \\
\hline Sex $=$ MDH E & 76.47 & 71.88 & 4.59 \\
\hline Sex = gn-id & 70.59 & 62.50 & 8.09 \\
\hline Sex = Alt FMD & 48.48 & 65.63 & -17.15 \\
\hline Sex= Alt FME & 67.65 & 59.38 & 8.27 \\
\hline Sex= Esp MD & 61.76 & 71.88 & -10.12 \\
\hline Sex = Esp ME & 55.88 & 68.75 & -12.87 \\
\hline Sex = cdl-cdl & 69.70 & 67.74 & 1.96 \\
\hline Sex = LmaxRD & 61.76 & 65.63 & -3.87 \\
\hline Sex = LmaxRE & 58.82 & 62.50 & -3.68 \\
\hline Sex = AngMD & 52.94 & 56.25 & -3.31 \\
\hline Sex = Ang ME & 53.85 & 64.52 & -10.67 \\
\hline Sex = go-go & 73.53 & 75.00 & -1.47 \\
\hline Sex $=$ LminRD & 55.88 & 59.38 & -3.50 \\
\hline Sex = LminRE & 58.82 & 68.75 & -9.93 \\
\hline Sex = Alt RD & 58.82 & 75.00 & -16.18 \\
\hline Sex = Alt RE & 61.76 & 81.25 & -19.49 \\
\hline Sex = CTM & 50.00 & 65.63 & -15.63 \\
\hline Sex = n-ns + ba-n + g-po + zy-zy & 80.77 & 96.15 & -15.38 \\
\hline
\end{tabular}

Legenda: g-op=Comprimento Máximo do Crânio; eu-eu= Largura Máxima do Crânio (Biéurio); zy-zy= Largura Bizigomática; ba$\mathrm{b}=$ Altura Básio- Bregma; ba- $\mathrm{n}=$ Comprimento Básio-Násio; ba-pr= Comprimento Básio-Próstio; ecm-ecm= Máxima Largura Alveolar; pr-alv= Máximo Comprimento Alveolar; $\mathrm{AUB}=$ Largura Biauricular; n-pr= Altura Facial Superior; ft-ft= Mínima Largura 
Frontal; fmt-fmt= Largura Facial Superior; $n-n s=$ Altura Nasal; al-al=Largura Nasal; $d-e c D=$ Largura Orbitária Direita; $d-e c E=$ Largura Orbitária Esquerda; $\mathrm{OBHD}=A$ ltura Órbita Direita; OBHE=Altura Órbita Esquerda; ec-ec=Largura Biorbitária; $d-d=$ Largura Interorbitária; $\mathrm{n}-\mathrm{b}=$ Corda Frontal; $\mathrm{b}-\mathrm{I}=$ Corda Parietal; $\mathrm{l}-\mathrm{o}=$ Corda Occipital; $\mathrm{ba}-\mathrm{o}=$ Comprimento do Forame Magno; $\mathrm{FOB}=$ Largura do Forame Magno; $\mathrm{MDHD}=$ Comprimento do Mastoide Direito; $\mathrm{MDHE}=$ Comprimento do Mastoide Esquerdo; gn-id= Altura do queixo (gn-id); Alt. FMD= Altura do Corpo da Mandíbula no Forame Magno Direito; Alt. FME= Altura do Corpo da Mandíbula no Forame Magno Esquerdo; Esp MD= Espessura do Corpo da Mandíbula no Forame Magno Direito; Esp ME= Espessura do Corpo da Mandíbula no Forame Magno Esquerdo; cdl-cdl= Largura Bicondilar; LmaxRD= Máxima Largura do Ramo Mandibular Direita; LmaxRE= Máxima Largura do Ramo Mandibular Esquerda; Ang. MD= Ângulo Mandibular Direito; Ang. $\mathrm{ME}=$ Ângulo Mandibular Esquerdo; go-go= Diâmetro Bigonial; LminRD= Largura Mínima do Ramo Mandibular Direito; LminRE= Largura Mínima do Ramo Mandibular Esquerdo; Alt.RD= Máxima Altura do Ramo Mandibular Direito; Alt.RE= Máxima Altura do Ramo Mandibular Esquerdo; CTM= Comprimento Mandibular

Através da análise discriminante linear, a maior porcentagem de acerto ocorreu na combinação das medidas Comprimento Básio-násio (ba-n), Comprimento Máximo do Crânio (g-op), Largura Bizigomática (zy-zy) e Altura Nasal (n-ns), com taxa de acerto de $80,77 \%$ para o sexo masculino e $96,15 \%$ para o feminino.

\subsubsection{Análise Discriminante Logística}

A tabela 5.12 mostra os índices de acerto das medidas para os sexos masculino e feminino pela análise discriminante logística.

Tabela 5.12 - Resultado da análise discriminante utilizando a análise discriminante logística para a determinação do sexo utilizando várias combinações de variáveis independentes

\begin{tabular}{llrrr}
\hline Model & Masc(\%) & Fem(\%) & Diff(\%) \\
\hline Sex $=$ g-po & 73.53 & 78.13 & -4.60 \\
\hline Sex $=$ eu-eu & 70.59 & 71.88 & -1.29 \\
Sex $=$ zy-zy & 77.42 & 80.00 & -2.58 \\
\hline Sex $=$ ba-b & 73.53 & 75.00 & -1.47 \\
Sex $=$ ba-n & 76.47 & 75.00 & 1.47 \\
\hline Sex $=$ ba-pr & 52.63 & 71.43 & -18.80 \\
Sex $=$ ecm-ecm & 62.07 & 57.14 & 4.93 \\
Sex $=$ pr-alv & 58.82 & 83.33 & -24.51 \\
Sex $=$ AUB & 54.84 & 70.97 & -16.13 \\
Sex $=$ n-pr & 60.00 & 85.71 & -25.71 \\
Sex $=$ ft-ft & 58.82 & 67.74 & -8.92 \\
Sex $=$ fmt-fmt & 63.64 & 50.00 & 13.64 \\
Sex $=$ n-ns & 77.78 & 80.77 & -2.99 \\
Sex $=$ al-al & 46.88 & 50.00 & -3.12 \\
Sex $=$ d-ec D & 69.70 & 55.17 & 14.53 \\
Sex $=$ d-ec E & 70.97 & 61.29 & 9.68 \\
Sex $=$ OBH D & 41.18 & 72.41 & -31.23 \\
Sex $=$ OBH E & 46.88 & 64.52 & -17.64 \\
\hline
\end{tabular}




\begin{tabular}{|c|c|c|c|}
\hline Sex $=$ ec-ec & 68.75 & 36.67 & 32.08 \\
\hline Sex $=d-d$ & 28.13 & 58.62 & -30.49 \\
\hline Sex $=n-b$ & 58.82 & 71.88 & -13.06 \\
\hline Sex = b-I & 66.67 & 73.08 & -6.41 \\
\hline Sex $=1-0$ & 73.53 & 73.08 & 0.45 \\
\hline Sex = ba-o & 64.71 & 65.63 & -0.92 \\
\hline Sex = FOB & 61.76 & 65.63 & -3.87 \\
\hline Sex $=$ MDH D & 70.59 & 68.75 & 1.84 \\
\hline Sex $=$ MDH E & 76.47 & 71.88 & 4.59 \\
\hline Sex = gn-id & 70.59 & 62.50 & 8.09 \\
\hline Sex $=$ Alt FMD & 61.76 & 65.63 & -3.87 \\
\hline Sex = Alt FME & 67.65 & 59.38 & 8.27 \\
\hline Sex= Esp MD & 64.71 & 71.88 & -7.17 \\
\hline Sex = Esp ME & 55.88 & 68.75 & -12.87 \\
\hline Sex $=$ cdl-cdl & 66.67 & 70.97 & -4.30 \\
\hline Sex = LmaxRD & 61.76 & 62.50 & -0.74 \\
\hline Sex = LmaxRE & 58.82 & 62.50 & -3.68 \\
\hline Sex $=$ AngMD & 52.94 & 56.25 & -3.31 \\
\hline Sex = Ang ME & 70.59 & 64.52 & 6.07 \\
\hline Sex = go-go & 73.53 & 75.00 & -1.47 \\
\hline Sex $=$ LminRD & 55.88 & 59.38 & -3.50 \\
\hline Sex $=$ LminRE & 61.76 & 62.50 & -0.74 \\
\hline Sex = Alt RD & 58.82 & 75.00 & -16.18 \\
\hline Sex = Alt RE & 64.71 & 75.00 & -10.29 \\
\hline Sex = CTM & 50.00 & 65.63 & -15.63 \\
\hline Sex = n-ns + ba-n + g-po + zy-zy & 92.31 & 92.31 & 0.00 \\
\hline
\end{tabular}

Legenda: g-op=Comprimento Máximo do Crânio; eu-eu= Largura Máxima do Crânio (Biéurio); zy-zy= Largura Bizigomática; ba$\mathrm{b}=$ Altura Básio- Bregma; ba-n= Comprimento Básio-Násio; ba-pr= Comprimento Básio-Próstio; ecm-ecm= Máxima Largura Alveolar; pr-alv= Máximo Comprimento Alveolar; $A U B=$ Largura Biauricular; $\mathrm{n}-\mathrm{pr}=$ Altura Facial Superior; ft-ft= Mínima Largura Frontal; fmt-fmt= Largura Facial Superior; $n-n s=$ Altura Nasal; al-al=Largura Nasal; $d-e c D=$ Largura Orbitária Direita; $d-e c E=$ Largura Orbitária Esquerda; OBHD=Altura Órbita Direita; OBHE=Altura Órbita Esquerda; ec-ec=Largura Biorbitária; $d$-d= Largura Interorbitária; $\mathrm{n}-\mathrm{b}=$ Corda Frontal; $\mathrm{b}-\mathrm{I}=$ Corda Parietal; $\mathrm{I}-\mathrm{o}=$ Corda Occipital; ba- $\mathrm{o}=$ Comprimento do Forame Magno; $\mathrm{FOB}=$ Largura do Forame Magno; $\mathrm{MDHD}=$ Comprimento do Mastoide Direito; MDHE= Comprimento do Mastoide Esquerdo; gn-id= Altura do queixo (gn-id); Alt. FMD= Altura do Corpo da Mandíbula no Forame Magno Direito; Alt. FME= Altura do Corpo da Mandíbula no Forame Magno Esquerdo; Esp MD= Espessura do Corpo da Mandíbula no Forame Magno Direito; Esp ME= Espessura do Corpo da Mandíbula no Forame Magno Esquerdo; cdl-cdl= Largura Bicondilar; LmaxRD= Máxima Largura do Ramo Mandibular Direita; LmaxRE= Máxima Largura do Ramo Mandibular Esquerda; Ang. MD= Ângulo Mandibular Direito; Ang. $\mathrm{ME}=$ Ângulo Mandibular Esquerdo; go-go= Diâmetro Bigonial; LminRD= Largura Mínima do Ramo Mandibular Direito; LminRE= Largura Mínima do Ramo Mandibular Esquerdo; Alt.RD= Máxima Altura do Ramo Mandibular Direito; Alt.RE= Máxima Altura do Ramo Mandibular Esquerdo; CTM= Comprimento Mandibular.

Assim como na análise discriminante linear, na logística, a maior porcentagem de acerto ocorreu na combinação das medidas Comprimento Básio-násio (ba-n), Comprimento Máximo do Crânio (g-op), Largura Bizigomática (zy-zy) e Altura Nasal (n-ns), com taxa de acerto de $92,31 \%$ para os sexos masculino e feminino. 


\subsubsection{Regressão Logística}

A tabela 5.13 apresenta as funções discriminantes que possuem um ponto de corte indicando a probabilidade em porcentagem de ser masculino ou feminino.

Tabela 5.13 - Equação da análise logística para a determinação do sexo utilizando diferentes combinações das variáveis quantitativas independentes para as medições

\begin{tabular}{|c|c|c|}
\hline Modelo & Equação & $\mathbf{P}$ \\
\hline Sex = g-op & $S=-45.10+g-o p^{*} 0.26$ & $<0.001$ \\
\hline Sex $=$ eu-eu & $S=-18.03+$ eu-eu ${ }^{*} 0.13$ & 0.001 \\
\hline Sex $=z y-z y$ & $S=-41.67+z y-z y * 0.33$ & $<0.001$ \\
\hline Sex = ba-b & $S=-20.78+b a-b * 0.16$ & $<0.001$ \\
\hline Sex = ba-n & $S=-30.27+b a-n * 0.31$ & $<0.001$ \\
\hline Sex $=$ ba-pr & $S=-9.76+$ ba-pr * 0.11 & 0.087 \\
\hline Sex $=$ ecm-ecm & $\mathrm{S}=-5.71+\mathrm{ecm}-\mathrm{ecm}{ }^{*} 0.10$ & 0.018 \\
\hline Sex $=$ pr-alv & $S=-6.68+$ pr-alv * 0.14 & 0.121 \\
\hline Sex $=$ AUB & $S=-17.60+A U B * 0.18$ & 0.001 \\
\hline Sex $=n-p r$ & $S=-12.19+n-p r * 0.20$ & 0.036 \\
\hline Sex $=\mathrm{ft}-\mathrm{ft}$ & $\mathrm{S}=-15.46+\mathrm{ft}^{-\mathrm{ft}}{ }^{*} 0.16$ & 0.003 \\
\hline Sex $=$ fmt-fmt & $S=-1.16+$ fmt-fmt $^{*} 0.13$ & 0.708 \\
\hline Sex $=$ n-ns & $S=-12.66+n-n s^{*} 0.26$ & 0.001 \\
\hline Sex = al-al & $S=-1.17+\mathrm{al}-\mathrm{al}{ }^{*} 0.05$ & 0.602 \\
\hline Sex $=d-e c D$ & $S=-17.10+d-e c D * 0.44$ & 0.002 \\
\hline Sex $=$ d-ecE & $S=-11.64+d-e c E * 0.30$ & 0.026 \\
\hline Sex $=$ OBHD & $S=-1.33+O B H D * 0.04$ & 0.333 \\
\hline Sex $=$ OBHE & $\mathrm{S}=-1.53+\mathrm{OBHE}^{*} 0.05$ & 0.262 \\
\hline Sex $=$ ec-ec & $S=-0.44+$ ec-ec * 0.01 & 0.784 \\
\hline Sex $=d-d$ & $S=-0.16+d-d * 0.01$ & 0.609 \\
\hline Sex $=n-b$ & $S=-16.90+n-b * 0.15$ & 0.002 \\
\hline Sex $=b-I$ & $S=-11.70+b-I^{*} 0.11$ & 0.007 \\
\hline Sex $=1-0$ & $S=-13.96+1-0 * 0.15$ & 0.001 \\
\hline Sex = ba-o & $S=-9.88+$ ba-o * 0.29 & 0.005 \\
\hline Sex = FOB & $S=-9.40+F O B * 0.32$ & 0.003 \\
\hline Sex $=$ MDHD & $S=-7.23+\mathrm{MDHD}^{*} 0.27$ & 0.001 \\
\hline Sex $=$ MDHE & $\mathrm{S}=-11.39+\mathrm{MDHE}{ }^{*} 0.42$ & 0.000 \\
\hline Sex $=$ gn-id & $S=-3.10+g n-i d * 0.13$ & 0.001 \\
\hline Sex $=$ AltFMD & $S=-3.27+$ AltFMD * 0.14 & 0.002 \\
\hline Sex = AltFME & $S=-3.16+$ AltFME $^{*} 0.14$ & 0.002 \\
\hline Sex = EspMD & $S=-3.34+E s p M D * 0.27$ & 0.028 \\
\hline Sex = EspME & $S=-2.90+$ EspME $^{*} 0.24$ & 0.076 \\
\hline Sex $=$ cdl-cdl & $S=-18.23+$ cdll-cdl $^{*} 0.16$ & $<0.001$ \\
\hline Sex = LmaxRD & $S=-6.38+$ LmaxRD * 0.21 & 0.008 \\
\hline Sex = LmaxRE & $S=-6.14+$ LmaxRE * 0.20 & 0.010 \\
\hline Sex = AngMD & $S=8.82+$ AngMD * -0.07 & 0.026 \\
\hline
\end{tabular}




\begin{tabular}{|c|c|c|}
\hline Sex = AngME & $S=11.90+$ AngME $^{*}-0.09$ & 0.012 \\
\hline Sex = go-go & $S=-19.66+$ go-go * 0.21 & $<0.001$ \\
\hline Sex = LminRD & $S=-4.26+L \operatorname{minRD} * 0.15$ & 0.041 \\
\hline Sex $=$ LminRE & $S=-5.20+\operatorname{LminRE}{ }^{*} 0.18$ & 0.020 \\
\hline Sex $=$ AltRD & $S=-8.33+$ AltRD * 0.17 & 0.001 \\
\hline Sex $=$ AltRE & $S=-9.84+$ AltRE * 0.20 & $<0.001$ \\
\hline Sex $=$ CTM & $S=-8.40+\mathrm{CTM}^{*} 0.08$ & 0.034 \\
\hline Sex = n-ns + ba-n + g-po + zy-zy & $\begin{array}{l}S=-135.89 n-n s * 0.29+\text { ba-n } * 0.56+\text { g-po * } 0.13 \\
+ \text { zy-zy *0.01 }\end{array}$ & $<0.001$ \\
\hline
\end{tabular}

Legenda: g-op=Comprimento Máximo do Crânio; eu-eu= Largura Máxima do Crânio (Biéurio); zy-zy= Largura Bizigomática; ba$\mathrm{b}=$ Altura Básio- Bregma; ba-n= Comprimento Básio-Násio; ba-pr= Comprimento Básio-Próstio; ecm-ecm= Máxima Largura Alveolar; pr-alv= Máximo Comprimento Alveolar; $\mathrm{AUB}=$ Largura Biauricular; $\mathrm{n}-\mathrm{pr}=$ Altura Facial Superior; $\mathrm{ft}-\mathrm{ft}=\mathrm{Mínima} \mathrm{Largura}$ Frontal; fmt-fmt= Largura Facial Superior; $n-n s=$ Altura Nasal; al-al=Largura Nasal; $d-e c D=$ Largura Orbitária Direita; $d-e c E=$ Largura Orbitária Esquerda; OBHD=Altura Órbita Direita; OBHE=Altura Órbita Esquerda; ec-ec=Largura Biorbitária; $d$-d= Largura Interorbitária; $\mathrm{n}-\mathrm{b}=$ Corda Frontal; $\mathrm{b}-\mathrm{I}=$ Corda Parietal; $\mathrm{I}-\mathrm{o}=$ Corda Occipital; ba- $\mathrm{o}=$ Comprimento do Forame Magno; $\mathrm{FOB}=$ Largura do Forame Magno; $\mathrm{MDHD}=$ Comprimento do Mastoide Direito; MDHE= Comprimento do Mastoide Esquerdo; gn-id= Altura do queixo (gn-id); Alt. FMD= Altura do Corpo da Mandíbula no Forame Magno Direito; Alt. FME= Altura do Corpo da Mandíbula no Forame Magno Esquerdo; Esp MD= Espessura do Corpo da Mandíbula no Forame Magno Direito; Esp ME= Espessura do Corpo da Mandíbula no Forame Magno Esquerdo; cdl-cdl= Largura Bicondilar; LmaxRD= Máxima Largura do Ramo Mandibular Direita; LmaxRE= Máxima Largura do Ramo Mandibular Esquerda; Ang. MD= Ângulo Mandibular Direito; Ang. $\mathrm{ME}=$ Ângulo Mandibular Esquerdo; go-go= Diâmetro Bigonial; LminRD= Largura Mínima do Ramo Mandibular Direito; LminRE= Largura Mínima do Ramo Mandibular Esquerdo; Alt.RD= Máxima Altura do Ramo Mandibular Direito; Alt.RE= Máxima Altura do Ramo Mandibular Esquerdo; CTM= Comprimento Mandibular

Para a análise discriminante logística com as medidas quantitativas, as equações que ofereceram os melhores resultados para ambos os sexos foram cinco. As duas primeiras envolvem as medidas Comprimento Básio-násio (75,73\%) e Comprimento Máximo do Crânio (g-op), com acerto de 75,83\%. A terceira refere-se á medida Largura Bizigomática (zy-zy), com 78,71\% de porcentagem de classificação correta. A seguinte, com acurácia de 79,27\% corresponde á Altura Nasal (n-ns). E, finalmente, a última, refere-se a uma combinação das melhores medidas, com um acerto de 92,31\%. Todas as fórmulas estão apresentadas abaixo:

$S=-30.27+$ Comprimento Básio- Násio (ba-n) x 0.31

$S=-45.10+$ Comprimento Máximo do Crânio (g-op) x 0.26

$S=-41.67+$ Largura Bizigomárica $(z y-z y) \times 0.33$

$S=-12.66+$ Altura Nasal (n-ns) $\times 0.26$ 
$\mathrm{S}=-135.89$ + Altura Nasal (n-ns) $\times 0.29$ + Comprimento Básio- Násio (ba-n) $x$ 0.56 + Comprimento Máximo do Crânio (g-po) x 0.13 + Largura Bizigomática (zyzy) $\times 0.01$

Apartir dessas fórmulas, obtem-se o valor do logito. A probabilidade de ser do sexo feminino (PF) e do masculino (PM) pode ser calculada segundo as equações:

$$
\begin{aligned}
& P F=1 /\left(1+e^{- \text {logito }}\right) \\
& P M=1-P F
\end{aligned}
$$

\subsection{RESULTADOS DA ANÁLISE DO MÉTODO DE OLIVEIRA}

\subsubsection{Validação da fórmula de Oliveira}

$\mathrm{Na}$ validação da metodologia de Oliveira et al. (1995), para a população estudada, usando-se a fórmula proposta pelo autor, o resultado para discriminação de sexo foi excelente para o feminino (100\% de acerto), porém, muito inferior para o masculino (11\% de acurácia). Por esse motivo, foi realizada uma validação da metodologia para a população estudada, com a criação de nova fórmula.

\subsubsection{Análise Discriminante Logística}

Foi realizada a Análise discriminante logística para verificar o acerto das medidas usadas na metodologia de Oliveira et al. (1995), demostrado na tabela 5.14 . 
Tabela 5.14. Analise discriminante logística do Método Oliveira

\begin{tabular}{lrrr}
\hline Modelo & Masc (\%) & Fem (\%) & Diff(\%) \\
\hline Sex = Alt. RM. ${ }^{*}$ Dist. Big. & 76.47 & 78.13 & -1.66 \\
\hline Legenda: Alt.RM= Altura do Ramo mandibular; Dist.Big= Distância Bigoníaca & & &
\end{tabular}

\subsubsection{Regressão Logística}

A regressão logística forneceu nova fórmula para discriminação do sexo (Tabela 5.15).

Tabela 5.15. Regressão logística do Método Oliveira

\begin{tabular}{lll}
\hline Modelo & Equação & P \\
\hline Sex $=$ Alt.RM ${ }^{*}$ Dist. Big. & S=-24.41 + Alt.RM* 0.14 + Dist.Big. * 0.18 & $\mathrm{p}=<0.001$ \\
\hline Legenda: Alt.RM= Altura do Ramo mandibular; Dist.Big= Distância Bigoníaca
\end{tabular}

\subsection{RESULTADOS DA ANÁLISE POR BIOLOGIA MOLECULAR}

\subsubsection{Condições ambientais da região de coleta das amostras}

A cidade de Guarulhos insere-se na Região Sudeste do Continente Sul Americano e, do ponto de vista do clima, apresenta os mesmos padrões de comportamento observados na Região Metropolitana de São Paulo, que dista cerca de $100 \mathrm{~km}$ do Oceano Atlântico, e tem a atuação da Massa Tropical Atlântica (quente e úmida) dada a barreira representada pela Serra do Mar. Com a ação marcante durante todo 0 ano, suas alternâncias com as massas polares, individualizadas pelo Anticiclone Migratório Polar, causam o abaixamento da temperatura e das ocorrências das chuvas frontais, principalmente, no período de outono-inverno. Durante o verão a atuação da massa Tropical Continental, individualizada pela Depressão Continental do Chaco, precede os avanços da Frente Polar, sendo responsável pelas intensas ondas de calor e tempo seco. 
A região do IML- Guarulhos (Instituto Médico Legal) apresenta um clima subtropical úmido, com temperatura média anual de $19^{\circ} \mathrm{C}$, umidade relativa do ar média anual de 81,1, precipitação pluviométrica anual média de $1470 \mathrm{~mm}$ e ventos dominantes SE - NO - E - O (Dados cedidos pelo Comando da Aeronáutica - Divisão de Meteorologia). O regime anual das chuvas permite identificar um forte componente sazonal, com chuvas concentradas nos meses de verão (inclui os meses de final de primavera), destacando-se o período seco, correspondente aos meses de inverno, quando em julho e agosto ocorrem as menores médias de precipitações. A umidade relativa média do ar é de $76 \%$ e a pressão média de 930,9 hpa, isolação de 133,9 horas/mês e 91,2 mm de evaporação.

$\mathrm{O}$ solo de onde foram retirados os esqueletos apresenta $\mathrm{pH}$ em torno de 5,5, o que significa que a concentração de íons $\mathrm{H}^{+}$presentes é alta, tornando esse solo ácido. A acidez do solo tem origem nas rochas que formam o solo, da interação do solo com o clima, principalmente em áreas onde a pluviosidade é elevada, na absorção dos sais alcalinos pelas plantas cultivadas ou pela reação ácida de certos produtos utilizados na fertilização do solo.

\subsubsection{Resultados da análise por DNA}

$\mathrm{Na}$ análise por DNA, do total de 65 elementos avaliados, 30 eram dentes e 35 vértebras. Apenas $23 \%(n=15)$ apresentaram condição satisfatória para a análise por DNA, sendo todos estes, dentes. Todas as vértebras estavam em situação ruim, com alterações, escavadas e esbranquiçadas, com aspecto fúngico.

Devido a não amplificação do gene, não foi possível determinar o sexo biológico em 13,85\% ( $n=09)$ da amostra, enquanto em 86,15\% ( $n=56)$ dos elementos, a determinação foi possível, conforme a leitura dos picos do gene amelogenina (Anexo $\mathrm{H}$ ).

No sexo masculino ( $n=33$ ), foi possibilitada a identificação sexual em 93,94\% $(n=31)$ da amostra, enquanto para os demais $(6,06 \%, n=2)$ esta determinação não ocorreu. Já no feminino ( $n=32$ ), foi possível a determinação do sexo em $78,12 \%$ $(n=25)$ dos elementos, enquanto que em $21,88 \%(n=7)$, esta identificação não ocorreu. 
Analisando-se os elementos nos quais ficou impossibilitada a discriminação sexual $(n=9)$, havia 6 vértebras e 3 dentes, sendo que apenas 1 destes elementos (1 dente) estava em situação satisfatória para estudo genético.

A distribuição do elemento analisado em cada crânio, classificando-os em dente ou vértebra, o sexo registrado no obituário, o estado em que se encontravam e o resultado da análise genética estão apresentados no Quadro 5.5. 


\begin{tabular}{|c|c|c|c|c|c|c|c|c|c|c|c|}
\hline Crânios & sexo & Dente & Vért. & Condição & Análise & Crânios & sexo & Dente & Vért. & Condição & Análise \\
\hline $001 / 11$ & $M$ & & $x$ & ruim & positiva & $034 / 10$ & $\mathrm{~F}$ & & $x$ & ruim & Positiva \\
\hline $002 / 10$ & & & & & excluído & $035 / 10$ & $M$ & $x$ & & ruim & Positiva \\
\hline $003 / 09$ & $\mathrm{~F}$ & & $x$ & ruim & positiva & $036 / 10$ & $\mathrm{~F}$ & $x$ & & ruim & Negativa \\
\hline 004/09 & $\mathrm{M}$ & $x$ & & ruim & positiva & $037 / 10$ & $\mathrm{M}$ & & $x$ & ruim & Positiva \\
\hline 005/09 & $\mathrm{M}$ & $x$ & & ruim & positiva & $038 / 10$ & $\mathrm{~F}$ & $x$ & & boa & Positiva \\
\hline $006 / 10$ & $M$ & $x$ & & ruim & positiva & $039 / 10$ & $\mathrm{~F}$ & $x$ & & boa & Positiva \\
\hline $007 / 10$ & $\mathrm{M}$ & $x$ & & ruim & positiva & $040 / 10$ & $\mathrm{M}$ & $x$ & & boa & Positiva \\
\hline $008 / 10$ & $\mathrm{~F}$ & & $x$ & ruim & positiva & $041 / 10$ & $\mathrm{~F}$ & $x$ & & boa & Negativa \\
\hline $009 / 10$ & $\mathrm{~F}$ & & $x$ & ruim & positiva & $042 / 10$ & M & $x$ & & boa & Positiva \\
\hline $010 / 10$ & $\mathrm{M}$ & $x$ & & boa & positiva & $043 / 11$ & $M$ & $x$ & & ruim & Positiva \\
\hline $011 / 10$ & $M$ & $x$ & & ruim & positiva & $044 / 11$ & $\mathrm{~F}$ & & $x$ & ruim & Negativa \\
\hline $012 / 10$ & $\mathrm{~F}$ & & $x$ & ruim & positiva & $045 / 11$ & $\mathrm{~F}$ & $x$ & & ruim & Positiva \\
\hline $013 / 10$ & $\mathrm{~F}$ & & $x$ & ruim & positiva & $046 / 11$ & $M$ & $x$ & & boa & Positiva \\
\hline $014 / 10$ & $M$ & & $x$ & ruim & positiva & $047 / 11$ & $\mathrm{~F}$ & $x$ & & boa & Positiva \\
\hline $015 / 10$ & $\mathrm{M}$ & & $x$ & ruim & positiva & $048 / 11$ & $\mathrm{M}$ & $x$ & & boa & Positiva \\
\hline $016 / 10$ & $\mathrm{~F}$ & & $x$ & ruim & positiva & $049 / 11$ & $\mathrm{~F}$ & $x$ & & boa & Positiva \\
\hline $017 / 10$ & $\mathrm{~F}$ & & $x$ & Ruim & positiva & $050 / 11$ & $M$ & $x$ & & boa & Positiva \\
\hline 018/10 & $\mathrm{M}$ & $x$ & & ruim & positiva & $051 / 11$ & $\mathrm{M}$ & $x$ & & boa & Positiva \\
\hline $019 / 10$ & $\mathrm{~F}$ & & $x$ & ruim & positiva & $052 / 11$ & $\mathrm{~F}$ & & $x$ & ruim & Positiva \\
\hline 020/10 & $\mathrm{F}$ & & $x$ & ruim & positiva & $053 / 11$ & $\mathrm{M}$ & & $x$ & ruim & Positiva \\
\hline $021 / 10$ & $\mathrm{M}$ & $x$ & & ruim & positiva & $054 / 11$ & $\mathrm{~F}$ & & $x$ & ruim & Negativa \\
\hline $022 / 10$ & $\mathrm{M}$ & $x$ & & ruim & negativa & $055 / 11$ & $\mathrm{M}$ & & $x$ & ruim & Positiva \\
\hline $023 / 10$ & $\mathrm{~F}$ & & $x$ & ruim & positiva & $056 / 11$ & $\mathrm{~F}$ & & $x$ & ruim & Negativa \\
\hline $024 / 10$ & $\mathrm{~F}$ & $x$ & & boa & positiva & $057 / 11$ & $\mathrm{~F}$ & & $x$ & ruim & Positiva \\
\hline 025/10 & $\mathrm{M}$ & $x$ & & ruim & positiva & $058 / 11$ & $M$ & & $x$ & ruim & Negativa \\
\hline $026 / 10$ & $\mathrm{~F}$ & $x$ & & ruim & positiva & $059 / 11$ & $\mathrm{M}$ & & $x$ & ruim & Positiva \\
\hline $027 / 10$ & $M$ & & $x$ & ruim & positiva & $060 / 11$ & $\mathrm{M}$ & & $x$ & ruim & Positiva \\
\hline $028 / 10$ & $\mathrm{~F}$ & & $x$ & ruim & positiva & $061 / 11$ & $\mathrm{~F}$ & & $x$ & ruim & Positiva \\
\hline 029/10 & $M$ & $x$ & & ruim & positiva & $062 / 11$ & $\mathrm{~F}$ & & $x$ & ruim & Positiva \\
\hline $030 / 10$ & $\mathrm{M}$ & & $x$ & ruim & positiva & $063 / 11$ & $\mathrm{~F}$ & & $x$ & ruim & Negativa \\
\hline $031 / 10$ & M & & $x$ & ruim & positiva & $064 / 11$ & $\mathrm{~F}$ & & $x$ & ruim & Positiva \\
\hline $032 / 10$ & $\mathrm{M}$ & $x$ & & boa & positiva & $065 / 11$ & $\mathrm{~F}$ & & $x$ & ruim & Positiva \\
\hline $033 / 10$ & $\mathrm{M}$ & $x$ & & boa & positiva & $066 / 11$ & $\mathrm{~F}$ & & $x$ & ruim & Negativa \\
\hline
\end{tabular}

Quadro 5.5 - Distribuição do elemento analisado em cada crânio, classificação em dente ou vértebra, sexo registrado no obituário, estado apresentado e o resultado da análise genética 


\subsection{COMPARAÇÃO DOS RESULTADOS MAIS IMPORTANTES}

$\mathrm{Na}$ tabela 5.16, são apresentadas as variáveis significativamente diferentes pelas análises discriminantes, as quais apresentam uma maior probabilidade de serem melhores discriminadoras do sexo no estudo realizado.

Tabela 5.16 - Comparação dos resultados mais importantes para o sexo masculino

\begin{tabular}{|c|c|c|c|}
\hline Método & $\begin{array}{l}\text { Anal. } \\
\text { Discr }\end{array}$ & Modelo & \% acerto \\
\hline Qualitativo & Linear & Sex $=$ Proc. Mast. + Em. Ment. & 88.05 \\
\hline Qualitativo & Linear & Sex $=$ Proc. Mast. + M. Supraorb. & 88.14 \\
\hline Qualitativo & Linear & Sex $=$ Proc. Mast. +Supraorb/ Glab. & 89.52 \\
\hline Qualitativo & Linear & Sex $=$ Proc. Mast. + M. Supraorb. + Supraorb/ Glab. & 89.52 \\
\hline Qualitativo & Logística & Sex = Proc. Mast. + M. Supraorb. + Supraorb/ Glab. & 87.96 \\
\hline Qualitativo & Logística & Sex = Proc. Mast. + M. Supraorb. + Em. Ment. & 89.52 \\
\hline Qualitativo & Logística & $\begin{array}{l}\text { Sex = C. Occip. + Proc. Mast. + M. Supraorb. + Em. } \\
\text { Ment. }\end{array}$ & 89.52 \\
\hline Qualitativo & Logística & Sex = Proc. Mast. +Supraorb/ Glab. & 89.52 \\
\hline Quantitativo & Linear & Sex $=n-n s$ & 75.43 \\
\hline Quantitativo & Linear & Sex $=$ ba-n & 75.83 \\
\hline Quantitativo & Linear & Sex $=g-p o$ & 75.92 \\
\hline Quantitativo & Linear & Sex $=z y-z y$ & 77.09 \\
\hline Quantitativo & Logística & Sex $=$ ba-n & 75.73 \\
\hline Quantitativo & Logística & Sex = g-po & 75.83 \\
\hline Quantitativo & Logística & Sex $=z y-z y$ & 78.71 \\
\hline Quantitativo & Logística & Sex $=n-n s$ & 79.27 \\
\hline Quantitativo & Linear & Sex $=n-n s+b a-n+g-p o+z y-z y$ & 88.01 \\
\hline Quantitativo & Logistica & Sex $=n-n s+b a-n+g-p o+z y-z y$ & 92.31 \\
\hline DNA & Descritiva & & 86.15 \\
\hline
\end{tabular}

A melhor taxa do método qualitativo foi $89,52 \%$, enquanto que o quantitativo teve $92,31 \%$, diferença estatísticamente insignificante. Porém, as melhores taxas de acerto da metodologia qualitativa ficaram no intervalo de 88 a $89,52 \%$, enquanto que, na quantitativa, oscilaram entre oscilaram entre 75 e $92 \%$

A maior porcentagem de acerto ocorreu através da Análise Discriminante Logística, pela combinação das medidas Comprimento Básio-násio (ba-n), Comprimento Máximo do Crânio (g-op), Largura Bizigomática (zy-zy) e Altura Nasal (n-ns), com taxa de acerto de $92,31 \%$ para ambos os sexos. 


\section{DISCUSSÃO}

No processo de identificação humana, o estabelecimento da identidade dos indivíduos é necessário devido ás circunstâncias éticas, legais e sociais envolvidas. E nesse contexto, a determinação do sexo é extremamente importante, pois facilita a construção do biótipo analisado para comparação com registros anteriores. E também, nos casos de desastres de massa ou escavações em sítios arqueológicos, quando há um número elevado de mortos ou esqueletos a serem identificados, possibilita a inserção dos mesmos em um dos dois grupos, masculino ou feminino. $\mathrm{Na}$ estimativa do sexo biológico podem ser aplicados os métodos da Antropologia Física e da Biologia Molecular.

Há uma movimentação entre os estudiosos da Antropologia Física na busca por protocolos internacionais de técnicas e métodos, através do aumento da cooperação entre os vários grupos de estudo. Tal fato pode ser constatado nas inúmeras produções científicas citadas ao longo deste trabalho, nas normatizações como a DVI, bem como na criação de bancos de dados resultantes da interação de grupos de diferentes regiões do mundo, como o FDB (1986) e Howells (1973). No Brasil não é diferente, sendo que se observa uma busca por interação entre os vários organismos envolvidos com o trabalho forense.

A existência de diferenças significativas entre os sexos masculino e feminino no que se refere á estrutura esquelética e morfológica é fato cientificamente reconhecido. Então, os trabalhos mostram uma concordância entre os autores de que, de modo geral, o esqueleto masculino apresenta-se maior, com estruturas mais robustas e mais proeminentes, enquanto que no feminino, observam-se essas mesmas estruturas com menor peso, mais delicadas e menos angulosas (Coma, 1991; Carvalho et al., 1992; França, 2007; Madeira, 2010).

Essas diferenças foram constatadas nessa pesquisa, pois os resultados mostraram que nos indivíduos do sexo masculino a grande maioria das medidas apresentou um valor médio superior ao encontrado nos indivíduos do sexo feminino. Tal fato comprova que a determinação do sexo poderá ser realizada por meio de mensurações cranianas, assim como descrito por vários autores como Peixoto, 1918; Abreu, 1929; Souza-Lima, 1938; Keen, 1950; Gilles; Elliot, 1963; Kajanoja, 1966; Konigsberg; Hens, 1998; Rogers, 2005; Dayal et al., 2008; Saini et al., 2012). 
Cabe uma exceção apenas para as medidas Largura Nasal (al-al), Máximo Comprimento Alveolar (pr-alv), Altura Facial Superior (n-pr), Largura Facial Superior (fmt-fmt), Altura da Órbita (OBH), Largura da Órbita (d-ec), Largura Biorbitária (ecec) e Espessura Mandibular (Esp. M), o que pode ser explicado por serem justamente aquelas em que houve dificuldades tanto na localização dos pontos, como na sua execução prática.

Sabe-se que o dimorfismo sexual pode ser influenciado por fatores étnicos. Por isso, uma mesma metodologia pode apresentar resultados diferenciados quando aplicadas em comunidade distintas para estimativa de sexo. Assim, existe a necessidade de pesquisas de acurácia e validação de métodos cujos resultados foram promissores em grupos raciais distintos. No Brasil, especialmente, tal análise se faz extremamente necessária por se tratar de um país com característica geral multiracial, com mistura entre brancos, negros e índios e com regiões distintas entre si, nas quais há miscigenações específicas e locais, como o Sul e o Nordeste (Johnson et al., 1989).

Nesse aspecto, os esqueletos humanos usados nesta pesquisa não foram selecionados pelo padrão de característica racial, portanto muitos dos indivíduos da amostra devem apresentar traços de miscigenação, principalmente por que, apesar do falecimento ter ocorrido em Guarulhos, vários deles eram naturais de outras regiões do país, como norte e nordeste, cuja população é multiracial, fato que deve ser associado aos resultados encontrados.

Por isso, as metodologias antropológicas usadas nesse trabalho foram selecionadas de acordo com os resultados de pesquisas publicadas realizadas em outra região do Brasil, como o método de Oliveira, ou em outros países, por exemplo, o método do Forensic Antropology Data Bank (FDB, 1986) e o de Walker (2008), cuja aplicação envolveu quatro populações diferentes.

No que se refere a do FDB (1986), parte do método já foi aplicado em outros estudos envolvendo populações mundiais com características raciais distintas, brancos, negros e amarelos, com acurácia maior que 80\% (Uytterschaut,1986; Konigsberg et al., 2009). Além disso, os dados encontrados na amostra dessa pesquisa foram enviados como uma contribuição brasileira para o FDB (http://fac.utk.edu/databank.html).

A metodologia de Oliveira et al. (1995) já havia sido aplicada em uma amostra da cidade de Salvador com taxa de acerto de $78,33 \%$, sendo, após esse estudo, 
agora validada em duas regiões do país com características culturais, sociais, geográficas e étnicas diferentes. Outro fator que contribuiu para a tentativa de validação do método de Oliveira é a possível ausência ou fragmentação do crânio nos cenários forenses, restando a mandíbula como determinante do sexo, por ser um osso mais compacto e resistente.

Alguns autores sustentam que o diagnóstico visual apresenta limitações, como a subjetividade do aplicador quando comparada com a objetividade de classificação utilizando-se técnicas com equipamentos, medições e análises discriminantes. Por outro lado, outros autores defendem que a metodologia qualitativa apresenta a maior praticidade na coleta de dados, a possibilidade de sua adequação para uso em fragmentos ósseos e a capacidade de avaliar os caracteres morfológicos não mensuráveis. Além disso, a aplicação de funções discriminantes na análise de medidas qualitativas é algo que tem sido muito aplicado nos trabalhos, sendo um fator contributivo para o aumento da credibilidade na aplicação desses métodos (Uytterschaut, 1986; Konigsberg; Hens, 1998; Walker, 2008).

Com o intuito de abranger a duplicidade das opções de análises antropológicas, nessa pesquisa foram aplicados dois métodos somatométricos (FDB, 1986; Oliveira et al. , 1995) e um somatoscópico (Walker, 2008). Assim, neste estudo, o método quantitativo apresentou uma taxa de acerto de $92,31 \%$ e a metodologia visual ficou em $89,52 \%$, com uma pequena diferença entre ambos de 2,79\%, o que não evidencia uma diferença estatisticamente significante. Porém, a metodologia qualitativa apresenta as vantagens de maior facilidade de aplicação resumindo-se á observação visual, o que não exige um grande treinamento como ocorre com a aplicação de mensurações envolvendo pontos craniométricos.

O índice de acerto obtido nesse estudo com a aplicação da Antropologia foi igual ou superior ao encontrado em outros estudos semelhantes, apontando que os métodos analisados apresentam alta eficácia de discriminação entre os sexos (Gilles; Elliot, 1963; Gilles, 1964; Kajanoja, 1966; Uytterschaut, 1986; Galvão, 1998; Galvão et al., 2002; 1998; Oliveira, 1995; Konisberg; Hens, 1998; Saliba, 1999; Valdrich et al., 2003; Rogers, 2005; Franklin et al., 2005; Williams; Rogers, 2006; Hu et al, 2006; Dayal et al., 2008; Walker, 2008; Robinson; Bidmos, 2009; Konigsberg et.al, 2009; Zavando et al., 2009; Hsiao et al., 2010; Naikmasur et al., 2010; Kharoshah et al., 2010; Saini et al., 2011a; Spradley; Jantz, 2011; Saini et al., 2012). 
Preliminarmente a realização desse estudo, houve um processo de calibração das pesquisadoras envolvidas, com o acompanhamento de uma professora de Anatomia. Nesse momento, foram analisados todos os elementos bem como os pontos craniométricos utilizados nos métodos, para que dúvidas fossem dirimidas, chegando-se a um consenso, principalmente nos pontos em que havia alguma divergência entre as pesquisadoras. Os resultados da calibração foram importantes pois mostraram que os métodos são reproduzíveis.

No método de Walker (2008), para o erro intraobservador, o índice Kappa evidenciou um acerto entre 50 a 100\%. Na avaliação interexaminador, tal índice apresentou-se menor para algumas variáveis, porém, ao se analisar a classificação nos escores de 1 a 5 feita pelas pesquisadoras, a diferença residia em apenas um número na escala, não havendo a possibilidade de erro na classificação final do sexo. Exemplificando, crânios femininos que para uma pesquisadora foram classificados no escore 1, para a outra, o foram no número 2 , o que não alterou o resultado final.

Já na calibração da metodologia do FDB (1986), foi necessário um estudo detalhado da definição anatômica de cada ponto craniométrico, seguido de um treinamento das pesquisadoras. Houve dúvidas na determinação dos pontos ectocântio, dácrio, frontomalar temporal e fronto temporal. Isso ocorreu porque as explicações encontradas na literatura sobre a localização destes pontos eram, muitas vezes, discrepantes entre si, ou devido a dificuldade na determinação dos mesmos em virtude de pequenas fraturas na região.

A mensuração envolvendo o ponto próstio não foi possível de ser analisada na maioria dos crânios por serem desdentados, portanto, sem a possibilidade de localização desse ponto. Especificamente no caso do ponto próstio (pr), a explicação encontrada na literatura refere-se ao fato de que em indivíduos desdentados, a estrutura da maxila varia muito em altura em virtude da perda óssea e, como consequência, os ponto próstio pode vir a sofrer algum tipo de alteração da sua posição original, sendo, impossivel a sua localização (Domitti, 1990; Figun; Garino, 1994; Madeira, 2010).

Ainda, com relação ao estudo piloto, houve dificuldade na obtenção da Largura nasal e da Altura da Órbita, por serem mensurações descritas de modo menos objetivo e, portanto, passíveis de erros na sua reprodução. 
$\mathrm{Na}$ validação da metodologia de Walker (2008), aplicando-se a fórmula proposta pelo autor, obteve-se $88,24 \%$ de acerto para homens e $81,25 \%$ para mulheres, resultado muito próximo do obtido por Walker $(88,4 \%$ para o sexo masculino e $86,4 \%$ para o feminino). Isso mostra que tal fórmula poderia ser utilizada para discriminação do sexo em crânios na população estudada, sem necessidade dos ajustes comuns na prática da antropologia, o que aumenta a amplitude de aplicação de tal método, valorizando as técnicas qualitativas, muitas vezes consideradas subjetivas e imprecisas.

E, embora os resultados desse estudo $(89,52 \%)$ tenham sido muito próximos dos obtidos por Walker (88\%), a classificação dos elementos nas categorias numéricos mostrou-se um pouco diferente do autor. Assim, observou-se que os crânios femininos classificaram-se entre as categorias 2 e 3 , enquanto que a maioria dos crânios masculinos apresentou o índice 3 e 4, com exceção do elemento Protuberância Mentual, que classificou esses crânios entre os escores 2 e 3. Já no estudo de Walker (2008), a maior parte dos crânios masculinos enquadrou-se nos escores 2, 3 e 4, enquanto que os femininos, nos escores 1 e 2, havendo variação entre as populações estudadas pelo autor (americana-africana, americana-européia, americana-inglesa e americana nativa). Essa distinção entre as duas pesquisas pode ser explicada pela diferença étnica, nutricional e cultural entre os grupos, fatores que influenciam o crescimento craniofacial, como o autor defende (Walker, 2008).

Ainda, pelo método somatoscópico, tomando-se cada elemento isoladamente, o melhor resultado para discriminação do sexo foi obtido com o Processo Mastóide pelas análises discriminantes linear e logística $(82,35 \%$ para o sexo masculino e $90,63 \%$ para o feminino), semelhante ao encontrado por outros estudos, como de Rogers (2005), Williams e Rogers (2006) e Walker (2008).

$\mathrm{Na}$ associação das variáveis, tanto para a análise discriminante linear como para a logística, os três elementos, processo mastóide, margem supraorbital e protuberância mentual produziram a maior acurácia, 89,52\%. Essa mesma porcentagem de acerto foi obtida quando a estes elementos somava-se a Crista occipital externa. Ou seja, para os modelos de análise discriminante linear e logística, as melhores proporções de acertos variaram entre $88 \%$ a $89,52 \%$, dependendo do número de traços utilizados na análise. Tal resultado é semelhante ao encontrado por alguns autores (Rogers, 2005; Williams; Rogers, 2006; Walker, 
2008) e maior do que o obtido por estudos baseados em medições craniométricas (Gilles, 1964; Kajanoja, 1966; Uytterschaut, 1986; Franklin et al., 2005; Dayal et al., 2008; Franklin et al., 2007). Além disso, essa porcentagem de acerto excede o valor de acurácia esperado para esse tipo de trabalho, que é o de igual ou maior que $80 \%$ (Walker, 2008).

Os achados encontrados na validação da fórmula do método de Walker bem como na análise estatística desse estudo com a avaliação visual dos crânios mostra que tal método é preciso e eficiente, com as vantagens da facilidade de aplicação, a possibilidade do uso em material forense fragmentado e o baixo custo, por não necessitar de equipamentos. Além disso, as análises discriminantes advindas desta análise podem fornecer fórmulas a serem utilizadas na determinação do sexo. Porém, devido as diferenças regionais, recomenda-se que antes da aplicação da referida metodologia, os ajustes populacionais sejam feitos, mesmo considerando os resultados promissores obtidos na população estudada, com característica multiracial.

Analisando-se os resultados da aplicação do Método somatométrico do FDB (1986), foi observado o maior índice de acerto nas medidas Altura Nasal $(79,27 \%)$ e a Largura Bizigomática (78,71\%). A Altura nasal foi reportada como um parâmetro de grande valia na discriminação do sexo em alguns trabalhos, como de Johnson et al. (1989), Uytterschaut (1986), Konigsberg et al. (2009), Saini et al. (2011a) e Spdradley e Jantz (2011). Já a Largura Bizigomática foi a melhor mensuração obtida em outros estudos, tais como o de Steyn e Iscan (1998), Valdrighi et al. (2003), Costa (2003), Franklin et al., (2005), Monticelli e Graw (2008), Kranioti et al. (2008), Naikmasur et al. (2010), Saini et al. (2011a) e Spdradley e Jantz (2011).

No trabalho de Franklin et al. (2005), a porcentagem de acerto da Largura Bizigomática foi de $77 \%$, resultado corroborado por subsequentes pesquisas realizadas por Kranioti et al. (2008), cuja acurácia foi de 83\% para essa variável, seguida da Altura Nasal, com 74,3\% e por Saini et al.(2011a), com acerto de $85,5 \%$. Também no trabalho de Dayal et al., (2008), encontrou-se uma precisão de 80,8\% com uma função aplicando os parâmetros Largura Bizigomática, Altura Nasal, Altura Básio-bregma e Máximo Comprimento do Crânio.

Após ampla revisão de trabalhos, Krogman e Iscan (1986), relataram que mesmo diante das interferências de fatores como raça, tipo de alimentação, tipo de cultura e clima, a Largura Bizigomática apresenta-se como uma característica 
importante na avaliação do dimorfismo sexual em vários tipos de populações, devendo ser sempre lembrada na realização de trabalhos de identificação humana.

Nessa pesquisa, o maior índice de acerto (92,31\%) para estimativa de sexo ocorreu com a somatória das mensurações Largura Bizigomática (zy-zy), Altura Nasal (n-ns), Comprimento Básio- Násio (ba-n) e o Comprimento Máximo do Crânio (g-op). De fato, são as medidas mais facilmente executadas e reproduzidas nos estudos, devido a facilidade de localização dos pontos, e também são reportadas com índices de acerto promissores na literatura científica (Johnson et al., 1989; Uytterschaut, 1986; Costa, 2003; Dayal et al., 2008; Konigsberg et al., 2009; Robinson; Bidmos, 2009; Naikmasur et al., 2010; Saini et al, 2011a; Spdradley; Jantz, 2011).

A análise discriminante logística permitiu a elaboração de uma fórmula com um índice de confiança de $92,31 \%$, dentro da média dos resultados de outros estudos com amostras brasileiras, que variam de 70 a 95\% (Daruge et al., 1975; Oliveira et al., 1995; Saliba 1999; Sampaio, 1999; Abe 2000; Ramalho et al., 2003; Francesquini, 2007).

Por outro lado, os resultados menos promissores encontrados nessa pesquisa no que se refere a craniometria, tanto na análise discriminante logística como na linear ocorreram com as mensurações Largura Interorbitária (d-d), 43,38\% a $45,10 \%$ de acerto, Largura Nasal (al-al), 48,44\%, Largura Biorbitária (ec-ec), $52,10 \%$, Ângulo mandibular, 54,60\%, e Altura da Órbita (OBH), com 55 a 57\% de acurácia.

Tal fato pode ser explicado pela dificuldade e menor objetividade na determinação dessas medidas. Algumas não são amparadas por pontos, mas por localização, como por exemplo, na Largura Nasal, que é definida pela distância máxima existente entre as bordas externas das asas do nariz (abertura nasal), de um lado ao outro, ou mesmo na Altura da Órbita, localizada entre as bordas superior e inferior da órbita esquerda, perpendicular ao longo eixo da órbita e à sua bissetriz. No caso das medidas Largura Nasal (al-al) e Altura da Órbita, outros trabalhos mostraram o mesmo achado, considerando-as medidas de menor valia para o dimorfismo sexual (Robinson; Bidmos, 2009; Saini et al., 2011a).

No que se refere as mensurações envolvendo os pontos dácrio e ectocântio, as justificativas plausíveis poderiam ser a dúbia interpretação sobre a determinação desses pontos quando se observa a literatura e a dificuldade de localização devido a 
fraturas na região da órbita. Nesse sentido, Husman e Samsom (2011) observaram que as medidas na região da órbita, altura e largura orbitária, não se mostraram estatisticamente significantes para a aplicação prática.

Os parâmetros métricos que fazem uso do ponto próstio, Comprimento BásioPróstio (ba-pr), Máximo Comprimento Alveolar (pr-alv), e Altura Násio Próstio também apresentaram resultados menos promissores para determinação do sexo. Sugere-se que a justificativa resida na ausência do ponto próstio em, pelo menos, metade dos crânios. Porém, esses parâmetros não foram retirados da análise devido aos resultados consistentes apresentados (62 a 72\%), mesmo que inferiores se comparados ás melhores medidas.

Em sua pesquisa, Oliveira et al. (1995) objetivou analisar o método de Lagunas (1974), baseado em quatro medidas mandibulares: Distância Bigoníaca, Altura do Ramo Mandibular, Comprimento Total da Mandíbula e Largura Mínima do Ramo Mandibular, e os resultados mostraram que, para a população de Salvador, apenas duas mensurações produziram boa acurácia, Distância Bigoníaca e Altura do ramo mandibular.

Neste estudo, na validação da metodologia de Oliveira, não se obteve sucesso com a aplicação da fórmula proposta pelo autor, com acerto muito díspare entre os sexos, $100 \%$ para mulheres e apenas $11 \%$ em homens, porcentagens muito diferentes dos resultados do autor $(81,11 \%$ no sexo feminino e $76,47 \%$ no masculino). Porém, quando se analisaram novamente os dados das medidas distância bigoníaca e altura do ramo mandibular, ajustando-as para a população estudada, obteve-se $76,47 \%$ de acurácia para homens e $78,13 \%$ para mulheres, com a criação de nova fórmula discriminante.

Essa diferença de resultados entre a população de Guarulhos (amostra desta pesquisa) e a de Salvador (amostra de Oliveira), reforça a questão da interferência da disparidade regional nos estudos antropológicos. Tanto que não foi possível a aplicação da fórmula de Oliveira da maneira como foi adaptada na população do nordeste do Brasil, mas sim um novo ajuste para a amostra do sudeste.

Nesta pesquisa optou-se pela análise estatística dos resultados antropológicos pela técnica da função discriminante, por caracterizar um método mais objetivo para determinação do sexo, cada vez mais usado pela sua confiabilidade. Além disso, aplicou-se a regressão logística, pois a construção de um modelo matemático para a discriminação sexual tem algumas vantagens, tais como, 
objetividade, elevados índices de precisão e confiabilidade, baixo custo e a não exigência de um maior tempo de experiência do perito na execução da metodologia (Bennett, 1981; Patil; Mody, 2004).

Devido a estes fatores positivos, a Antropologia Física consagrou-se como ciência escolhida na rotina dos serviços de identificação humana. No entanto, como descreveram Schmerer (2001), Ganswindt et al. (2003), Arruda et al. (2007), Caramelli et al. (2007), Vanek et al. (2009), Vieira et al. (2010) e Lupta'kova' et al. (2011), a identificação antropológica tornou-se uma tarefa um tanto quanto árdua em casos cujos indivíduos a serem identificados encontravam-se nas seguintes situações: em sítios arqueológicos com peças ósseas humanas mescladas às de animais; corpos ou ossadas quase totalmente fragmentados; e faixa etária aquém da puberdade, com características somatométricas e somatoscópicas indiferenciadas.

Consecutivamente, o uso da genética forense ingressou como adjuvante ou complementar das metodologias empregadas rotineiramente nos Institutos Médicoslegais do Brasil (Silva; Oliveira, 2008). Entretanto, é importante destacar que a biologia molecular, ao contrário da ideia de irrevogabilidade, apresenta algumas dificuldades, como a interferência das condições ambientais e a complexidade da técnica, composta de várias etapas, e ainda com a necessidade de equipamentos e reagentes específicos. Além disso, nos serviços ocorre uma demanda desordenada quanto ás solicitações de análises por DNA, sem uma triagem quanto ao melhor método a ser utilizado para a elucidação do caso. Assim sendo, situações que poderiam ser resolvidas de modo eficiente com a Antropologia são encaminhadas para estudo genético, aumentando o custo e retardando o processo de identificação.

O presente trabalho investigou o sexo dos esqueletos utilizando amostras de dentes e ossos, elementos comuns na análise forense, considerados os restos humanos melhor preservados devido ao arcabouço ósseo e a maior resistência (Arismendi et al., 2004). A maior parte da amostra (77\%) apresentou-se em condição insatisfatória, ou seja, com sujeira, umidade e envolta em folhas e terra. Particularmente, todas as vértebras tinham um aspecto esbranquiçado compatível com presença de fungo, porções destruídas e facilmente desintegradas ao toque, fato que provavelmente possa justificar o pior resultado destes elementos no estudo genético (das 9 que não amplificaram, 6 eram vértebras).

$\mathrm{Na}$ análise aplicando-se o gene amelogenina para determinação do sexo, foi possível determinar o sexo biológico em $86,15 \%(n=56)$ dos elementos, resultados 
que estão de acordo com o encontrado por Velarde-Félix et al. (2008) e Santos (2009) os quais obtiveram amplificação de 100\% de suas amostras e Santos (2012), com 84,6\%. Proporções decrescentes foram encontradas por Tschentscher et al. 2008, com 50\% e por Ganswindt et al. em 2003 e Ricaut et al. em 2005, com 43\%.

Acredita-se que a taxa de $13,5 \%$ de insucesso $(n=9)$ na classificação sexual tenha ocorrido principalmente pela condição precária da amostra, culminando na obtenção de um material genético de ínfima qualidade, muito degradado, conforme observado na quantificação das amostras, respaldado na literatura (Lee; Laad, 2001; Ricault et al., 2005; Arismendi et al., 2004; Bonaccorso, 2004; Duarte et al., 2010; Sjoholm et al., 2007). E embora não se possa afirmar categoricamente, há um forte indicativo de que a qualidade das amostras tenha influenciado sim nesse resultado, já que das 9 que não amplificaram, apenas uma (dente) estava em condição satisfatória.

No que se refere a concordância entre o sexo encontrado e o sexo real do indivíduo, foi possível a determinação sexual em 93,94\% da amostra masculina e $(n=31)$ e em 78,12\% $(n=25)$ da feminina. Nenhuma amostra masculina apresentou erro de leitura, como sendo homozigoto (XX). Assim, nesse estudo, não se observou a questão da "deleção amelogênica masculina" ou DAM, reportada por alguns autores (Steinlechner et al., 2002; Michael; Brauner, 2004; Lattanzi et al., 2005; Kashyap et al., 2006; Chang et al., 2007). Portanto, nos casos em que não foi possivel a determinação do sexo, isso ocorria devido a ausência da amplificação do gene, sem a formação de pico na imagem. Os resultados obtidos com a amostra masculina foram muito relevantes pois a grande dificuldade na utilização da amelogenina apresenta-se somente no referido sexo, de acordo com a literatura.

Finalmente, comparando-se os melhores resultados encontrados na aplicação da Antropologia Física, cuja metodologia qualitativa apresentou em torno de $89 \%$ e a quantitativa, $92,31 \%$ com os dados obtidos na análise por DNA pelo gene amelogenina $(86,15 \%)$, pode-se afirmar que as diferentes metodologias comportaram-se de modo semelhante no que se refere á precisão na determinação do sexo de amostras forenses.

Portanto, a escolha do método para estimativa de sexo deve se pautar na análise do estado e apresentação do vestígio forense, bem como na observação do contexto do serviço forense, levando-se em consideração a aplicabilidade, a reprodutibilidade, o custo de material e a complexidade do método. Nesses 
aspectos, a Antropologia desponta com vantagem em relação ao DNA, apresentando como único inconveniente a necessidade de ajuste da metodologia escolhida em virtude das diferenças étnicas entre os grupos populacionais. No caso da biologia molecular, tal padronização não se faz necessária. Além disso, numa análise por DNA, raramente estuda-se apenas o sexo, mas sim traça-se todo o perfil genético do indivíduo, possibilitando a obtenção de informações que poderão compor um banco de dados.

Assim, como resultado desse trabalho, recomenda-se que a antropologia física seja a ciência de escolha, preferencialmente, a somatoscopia. 


\section{CONCLUSÕES}

Após análise dos resultados do trabalho, foi possível concluir que:

1. Todas as metodologias usadas na Antropologia Física apresentaram acurácia acima de $76 \%$ para a determinação do sexo.

2. Dentre todas as medidas realizadas no método FBD (1986), as que apresentaram maior dimorfismo entre os sexos foram a Altura Nasal e a Largura Bizigomática. Já quanto aos parâmetros qualitativos, o melhor resultado foi obtido com o Processo Mastóide.

3. Na análise genética com o gene amelogenina para determinação sexual, foi possível determinar o sexo biológico em $86,15 \%(n=56)$ dos elementos.

4. Comparando-se o acerto da Antropologia Física, $89 \%$ e 92,31\%, com o do DNA, $(86,15 \%)$, pode-se afirmar que as diferentes metodologias comportaram-se de modo semelhante no que se refere á precisão na determinação do sexo de amostras forenses. 


\section{REFERÊNCIAS ${ }^{1}$}

Abe DM. Avaliação do sexo por análise da função discriminante a partir de dimensões lineares do crânio [dissertação]. Piracicaba: Universidade Estadual de Campinas, Faculdade de Odontologia de Piracicaba; 2000.

Abreu HT. Medicina legal aplicada à arte dentária. $2^{\underline{a}}$ ed. Rio de Janeiro: Francisco Alves; 1929.

Adréasson $\mathrm{H}$, Allen M. Rapid quantification and sex determination of forensic evidence materials. J Forensic Sci. 2003;48(6):1-8.

Alcântara HR. Perícia médica judicial. Rio de Janeiro: Guanabara Koogan; 1982.

Almeida Júnior AF, Costa Junior JB. Lições de medicina legal. 17 ed. São Paulo: Nacional; 1981.

Almeida Junior E, Galvão LCC. Investigação do sexo através de uma área triangular facial formada pela interseção dos pontos: forame infraorbital direito, esquerdo e 0 prósito, em crânio secos de adultos. Rev Ciênc Méd e Biol. 2010;9:3-11.

Almeida Junior E, Martins T, Galvão LCC. Investigação do sexo através de mensurações faciais em crânios secos. Rev Fac Odontol Univ Fed Bahia.2002;24:611.

Amoedo O. Study of teeth after death from medical standpoint. Dent. Dig., Pittsburg. 1903;9:604-8.

Arbenz GO. Medicina Legal e Antropologia Forense. 1를. Rio de Janeiro: Atheneu; 1988.

Arismendi JL, Bajer LE, Matteson KJ. Effects of processing techiques on the forensic DNA analysis of human skeletal remais. J Forensic Sci 2004;49(5):1-5.

Arruda DG, Hirata MH, Barreto OC. Pitfalls in DNA extraction from ancient bones found in brazilian shell-mounds. Rev Museu Arqueo e Etnol. 2007;(17):461-67.

\footnotetext{
${ }^{1}$ De acordo com Estilo vancouver.
} 
Avila JB. Antropologia física. Rio de Janeiro: Livraria Agir Editora; 1958.

Benecke M. Forensic DNA samples: Collection and handling. Encyclopedia of Diagnostic and Proteomics [serial on the internet]. 2005. [acesso 2006 maio 18]. Avaiable from: http://www.benecke. com/dnacollection.pdf.

Bennett KA. On the expression of sex dimorphism. Am J Phys Anthropol. 1981 Sept; 56(1):59-61.

Betancor E, Fregel R, Almeida M, Sua' rez NM, Pestano J. DNA typing for the identification of eight victims of Spanish Civil War reprisals in the Canary Islands: The case of "the Fuencaliente thirteen" mass graves (Fuencaliente, La Palma). Forensic Sci Int. 2011; Genetics Supplement Series 3:301-e302.

Bonaccorso N. Análise forense de DNA [monografia]. São Paulo: ACADEPOL Academia de Polícia de São Paulo; 2004.

Boadas J. Atentado em Madrid. [acesso 8 jun 2005]. Disponível em: URL:http//www.anabad.org/noticias.

Brannon RB, Morlang WM. The USS lowa disaster: success of the forensic dental team. J Forensic Sci. 2004;49(5):1067-8.

Brasil. Conselho Federal de Odontologia. Lei 5.081, de 24 de Agosto de 1966. Regulamenta o exercício da Odontologia no Brasil. Diário Oficial da União, Brasília (DF); 1966.

Brasil. Conselho Federal de Odontologia. Resolução №. 63, de 30 de Junho de 2005, atualizada em Março de 2010. Consolidação das normas para procedimentos nos conselhos de Odontologia. Rio de Janeiro: CFO; 2010.

Brasil. Instituto Brasileiro de Geografia e Estatística. Relatório de Impacto ambiental. 2012 [acesso 10 jan 2012]. Disponível em http://www.ibge.gov.br/home.

Brinkmann B. Forensic Anthropology. Int J Legal Med. 2007;121:431-2.

Budmlija ZM, Mechthild KP, Mundorff AZ, Wieraema J, Bartelink E, Mackinnon G et al. World Trade Center Human Identification Project: Experiences with individual body identification cases. Croat Med J. 2003;44(3):259-63. 
Buikstra JE, Ubelaker DH. Standards for data collection from human skeletal remains. Proceedings of a seminar at the Field Museum of Natural History, organized by Jonathan Haas. Fayetteville, AK: Arkansas Archeological Survey; 1994.

Butler JM. Forensic DNA typing: Biology and technology behind STR markers. New York: Academic Press; 2001.

Camargo JR. Estimativa do sexo através das características radiográficas dos seios frontais [tese]. Piracicaba: Universidade Estadual de Campinas, Faculdade de Odontologia de Piracicaba; 1999.

Campos PF, Craig OE, Turner-Walkere G, Peacock E, Willersleva E, Gilberta MTP. DNA in ancient bone - Where is it located and how should we extract it? Ann Anat.194:2012; 7- 16.

Campobasso CP, Falamingo R, Vinci F. Investigation of Italy's deadliest building collapse: forensic aspects of a mass disaster. J Forensic Sci. 2003;48(3):635-9.

Caramelli D, Lalueza-Fox C, Capelli C, Lari M, Sampietro ML, Gigli E, et al. Genetic analysis of skeletal remains attributed to Francesco Petrarca. Forensic Sci Internat. 2007;(173):36-40.

Cardoso IML. Estudo cefalométrico do perfil nasofacial [dissertação]. Piracicaba: Universidade Estadual de Campinas, Faculdade de Odontologia de Piracicaba; 1993.

Cardoso S, Etxeberria F, Alfonso-Sanchez MA, Perez-Miranda AM, Odriozola A, Valverde $L$, et al. Contribution of forensic genetics to the recovery of historic memory of the Spanish Civil War. Forensic Sci Int. 2008; Genetics Supplement Series (1): 54-56.

Carvalho HV, Segre M, Meira AR, Alemdia M, Salaru NNR, Munoz DR, et al. Compêndio de Medicina legal. 2ª ed. São Paulo: Editora Saraiva; 1992.

Cassiman JJ. DNA profiling in forensics. In: Willems G. Forensic odontology. Proceedings of the European IOFOS Millennium Meeting. Bélgica: 2000. [acesso 10 jun 2010]. Disponível em: http://upers.kuleuven.be/en/titel/9789058670519.

Cattaneo C. Forensic anthropology: developments of a classical discipline in the new millenium. Forensic Sci Int. 2007;165(2-3):185-93. 
Cattaneo C, Porta D, De Angelis D, Gibelli D, Poppa P, Grandi M. Unidentified bodies and human remains: an Italian glimpse through a European problem. Forensic Sci Int. 2010;195(1-3):167.e1-6.

Celbis O, Iscan MY, Soysal Z, Cagdir S. Sexual diagnosis of the glabellar region. Legal Med. 2001;3:162-70.

Cerri N, Ricci U, Verzeletti A, Falconi B, De Ferrari F. Typing of teeth two different amplification systems. International Congress Series. 2004;1261:622-4.

Chang YM, Perumal R, Keat PY, Yong RY, Kuehn DL, Burgoyne L. A distinct Y-STR haplotype for Amelogenin negative males characterized by a large $Y_{p} 11.2$ (DYS458MSY1-AMEL-Y) deletion. Forensic Sci Int. 2007;166:115-20.

Chen L, Sun G, Wu M. Influence by environmental and physicochemical factors on th results of sex identification of human dental pulp by polymerase chain reaction. Hua Xi Yi Ke Da Xue Bao. 1994;25(3):253- 8.

Clayton TM, Whitaker JP, Maguirre CN. Identification of bodies from scene of mass disaster using DNA amplification of short tandem repeat (STR) loci. Forensic Sci Int. 1995;76:7-15.

Coma JMR. Antropologia forense. Madrid: Centro de Publicacion Secretaria General Técnica. Ministério da Justiça; 1991.

Cornélio Neto WL. Dimorfismo sexual por meio do neurocrânio de humanos: método digital [tese]. Piracicaba: Universidade Estadual de Campinas; Faculdade de Odontologia de Piracicaba; 2010.

Costa AA. Determinação do sexo por meio de medidas craniométricas e sua importância pericial [dissertação]. Piracicaba: Universidade Estadual de Campinas, Faculdade de Odontologia de Piracicaba; 2003.

Croce D, Croce-Júnior D. Manual de medicina legal. 5aㅗ ed. São Paulo: Saraiva; 2004.

Daskalaki E, Anderung C, Humphrey L, Götherström A. Further developments in molecular sex assignment: a blind test of 18th and 19th century human skeletons. J Archaeol Sci. 2011;38:1326-30. 
Daruge E, Massini N, Galdino AM. Ensaio de sistematização do ensino da odontologia legal e deontologia odontológica. Piracicaba: Universidade Estadual de Campinas, Faculdade de Odontologia de Piracicaba; 1975.

Daruge E. Determinação do sexo pelo esqueleto cefálico de indivíduos adultos atravé de radiografias cefalométricas em norma lateral. Bol Fac Odontol. Piracicaba,1965 Mar;9:1-10.

Dayal MR, Spocter MA, Bidmos MA. An assessment of sex using the skull of black South Africans by discriminant function analysis. HOMO.2008;59:209-21.

De Leo D, Turrina S, Marigo M. Effects of individual dental factors on genomic DNA analysis. Am J Forensic Med Pathol. 2000;21(4):411-5.

Dirkmaat DC, Cabo LL, Ousley SDA, Symes SA. New perspectives in forensic anthropology. Yearbook Phy Anthropol. 2008;51:33-52.

Domitti SS. Sistematização do ensino integrado da prótese total. São Paulo: Editora Santos; 1990. p. 12-4.

Duarte GRM, Price CW, Littlewood JL, Haverstick DM, Ferrance JP, Carrilho E, et al. Characterization of dinamyc solid phase DNA extraction from blood with magnetically controlled silica beads. Royal Soc Chemistry/ Analyst. 2010;135:531-7.

Faerman M, Filon D, Kahila G, Greenblatt CL, Smith P, Oppenheim O. Sex identification of archeological human remains based on amplification of the $X$ and $Y$ amelogenin alleles. Gene. 1995;167:327-32.

Farah SB. DNA: segredos \& mistérios. 2ª ed. São Paulo: Sarvier; 2007.

Faro CCP. Processo de extração de DNA contaminado com solo [tese]. São Cristóvão: Universidade Federal de Sergipe, Rede Nordeste de Biotecnologia, Renorbio; 2012.

Ferreira FV, Villi ER. Estudo da largura máxima da abertura piriforme em crânios humanos de brancos e negros brasileiros de ambos os sexos. Rev. Fac. Odontol. S Paulo.1968 Jan/Mar;6 (1):5-10.

Ferreira RA. Reconhecendo pela boca. Rev Assoc Paul Cir Dent. 1996;50(6):464-73. 
Figun ME, Garino RR. Anatomia odontológica funcional e aplicada. 3. ed. Buenos Aires: Editora Medicina Panamericana do Brasil; 1994. p. 641-50.

Figini ARL, Silva JRL, Jobim LF, Silva M. Identificação humana. São Paulo: Editora Milleniun; 2003.

FDB - Forensic Anthropology Data Bank [homepage na internet]. Tennesse: University of Tennesse; Departament of Anthropology; 1986 [cited 2010 aug 10]. Available from: http://fac.utk.edu/databank.html.

Francesquini MA. Avaliação da medida de comprimento de ossos longos de individuos adultos quanto ao dimorfismo sexual [tese]. Piracicaba: Universidade Estadual de Campinas, Faculdade de Odontologia de Piracicaba; 2007.

França GV. Medicina legal. 8ª ed. Rio de Janeiro: Guanabara Koogan; 2007.

Franklin D, Freedman L, Milne N. Sexual dimorphism and discriminant function sexing in indigenous South African crania. HOMO. 2005;55:213-28.

Franklin D, Oxnard C, O'Higgins P, Dadour I. Sexual dimorphism in the subadult mandible: quantification using geometric morphometrics. J Forensic Sci. 2007;52(1): 6-10.

Galdames ICS, Matamala DAZ, Smith RL. Sex determination using mastoid process measurementes in brazilian skulls. Int J Morphol. 2008;26(4):941-44.

Galvão LCC, Almeida Junior E, Araújo TM. Investigaçào do sexo através de mensurações faciais em crânios secos. Rev Fac Odontol Univ Fed Bahia. 2002 Jan/Jun;24:6-11.

Galvão LCC. Determinação do sexo através da curva frontal e apófise mastoide [tese]. Piracicaba: Universidade Estadual de Campinas, Faculdade de Odontologia de Piracicaba; 1998.

Gapert R, Black S, Last J. Se determination from the foramen magnum: discriminant function analysis in an eighteenth and nineteenth century British sample. Int $\mathrm{J}$ Legal Med. 2009;123:25-33. 
Ganswindt M, Ehrlich E, Klostermann P, Troike WG, Schneider V. Bone finds: a challenge to forensic science. Legal Med. 2003;5:382-385.

Gibbon V, Paximadis M, Strkalj G, Ruff P, Penny C. Novel methods of molecular sex identification form skeletal tissue using the amelogenin gene. Forensic Sci Int (Genetics). 2009;3:74-9.

Gilbert MTP, Willerslev E, Hansen AJ, Barnes I, Rudbeck L, Lynnerup N, et al. Distribution patterns of postmortem damage in human mitochondrial DNA. Am J Hum Genet. 2003;72:32-47.

Giles $E$, Elliot $O$. Sex determination by discriminant function analysis of crania. Am J Phys Anthropol. 1963;21:53-68.

Giles E. Sex determination by discriminant function analysis of the mandible. Am J Phys Anthropol. 1964;22:129-36.

Hebsgaard MB, Phillips MJ, Willerslev E. Geologically ancient DNA: fact or artefact? Microbiology.2005 May;13(5): 212-20.

Hill CR, Butler JM, Vallone PM. A 26plex autosomal STR assay to aid human identity testing. J Forensic Sci. 2009;54(5):1008-15.

Hoshi $\mathrm{H}$. Sex difference in the shape of the mastoid process in nome occipitalis and its importance to sex determination of the human skull. Okajima's Folia Ant Jpn. 1962;38:309-17.

Hoss $M$, Jaruga $P$, Zastawny TH, Dizdaroglu M, P"a"abo S. DNA Damage and DNA sequence retrieval from ancient tissues. Nucleic Acids Res. 1996;24:1304-7.

Howells WW. Cranial variation in man: a study by multivariate analysis of patterns of difference among recent human populations. Cambridge, MA: Peabody Museum of Archaeology and Ethnology; 1973.

Hsiao TH, TsaiSM, Chou ST, Pan JY, Tseng YC, Chang HP, et al. Sex determination using discriminant function analysis in children and adolescents: a lateral cephalometric study. Int J Legal Med. 2010;124:155-60. 
Hu KS, Koh KS, Han SH, Shin KJ, Kim HJ. Sex determination using nonmetric characteridtics of the mandible in Koreans. J Forensic Sci. 2006;51(6):1376- 82.

Husmann PR, Samson DR. In the Eye of the Beholder: Sex and Race Estimation using the Human Orbital Aperture. J Forensic Sci. 2011;56(6):1424-29.

Internacional Criminal Police Organization (Interpol). Disaster Victim Identification Guide [guide online] 2009. [cited 2012 oct 05]. Avaiable from:

http://www.interpol.int/INTERPOL-expertise/Forensics/DVI.

Íscan YM, Olivera HES. Forensic anthropology in Latin America. Forensic Sci Int. 2000;109(1):15-30.

Iscan YM. Global forensic anthropology in the 21st century [editorial]. Forensic Sci Int. 2001;117:1- 6 .

Iwawura ESM, Oliveria CR, Soares-Vieira J, Nascimento SAB, Munõz DR. A qualitative study of compact boné microstructure and nuclear short tandem repeat obtained from fêmur of human remains found on the ground and exhumed 3 years after death. Am J Forensic Med Pathol. 2005;26:33-44.

Johnson DR, O'Hihhins P, Moore WJ, McAndrew TJ. Determination of race and sex of the human skull by dicriminant function analysis of linear and angular dimensions. Forensic Sci Intl. 1989;41:41-53.

Kajanoja P. Sex determination of finnish crania by discriminant function analysis. Am J Phys Antropol. 1966,24:29-34.

Kashyap VK, Sahoo S, Sitalaximi T, Trivedi R: Deletions in the Y-derived amelogenin gene fragment in the Indian population. BMC Med Genet. 2006;7:37.

Knapp M, Clarkea AC, Horsburgha KA, Matisoo-Smitha EA. Setting the stage Building and working in an ancient DNA laboratory. An Anat. 2012;194:3- 6.

Keen JA. A study of the differences between male and female skulls. Am J Phys Anthropol. 1950;8: 65-78.

Kemkes A, Göbel T. Metric Assessment of the "Mastoid Triangle" for sex determination: a validation study. J Forensic Sci. 2006;51(5):985-9. 
Kemp BM, Smith DG. Use of bleach to eliminate contaminating DNA form the surface of bones and teeth. Forensic Sci Int. 2005;154:53-61.

Kharoshah MAA, Almadami O, Ghaleb SS, Zaki MK, Fattah YAA. Sexual dimorphism of the mandible in a modern Egyptian population. J Forensic Legal Med.

2010;17:213-5.

Kim K, Kim KY, Jeon E, Togloom A, Cho YO, Lee MS, et al. Technical note: improved anciente DNA purification for PCR using lon-exchange columns. Am J Phys Anthropol. 2008;136:114-21.

Kimmerle EH, Ross A, Slice D. Sexual dimorphism in America: geometric morphometric analysis of the craniofacial region. J Forensic Sci. 2008;53(1) 54-7.

Konigsberg LW, Bridget FBAH, Steadman DW. Estimation and evidence in forensic anthropology: sex and race. Am J Phy Anthropol. 2009;139:77- 90.

Konigsberg LW, Hens SM. Use of ordinal categorical variables in skeletal assessment of sex from the cranium. Am J Physical Anthropol. 1998;107:97-112.

Kranioti EF, Iscan MY, Michalodimitrakis M. Craniometric analysis of the modern Cretan population. Int Sci Forense. 2008;180(2-3):110.e1-110.e5.

Krogman WM, Iscan MY. The human skeleton in Forensic Medicine. 2. ed. Ilinois: Thomas Plublisher; 1986. p.189-267.

Kumar MG, Hedge AM. Sex identification from exfoliated primary teeth a PCR study. J Clin Pediatr Dent. 2005;30 (1):19-21.

Lacassagne A, Martin E. Medicina légale. 3를d. Paris: Editora Masson; 1921.

Lagunas Z. La determinacion sexual em mandíbulas por medio de las Funciones Discriminantes. México D.F: Anales del INAH; 1974. p. 171-74.

Lakai FM, Botha A, Prior BA. Comparation analysis of environmental DNA extraction and purification methods from different humic acid - rich soil. J App Microbiol. 2007;102:265-73. 
Lau G, Tan WF, Tan PH. After the Indian Ocean tsunami: Singapore's contribution to the internacional disaster victim identification effort in Thailand. Ann Acad Med. 2005; 34(5):341-51.

Lattanzi W, Giacomo MCD, Lenato GM, Chimiente G, Voglino G, Resta N et al. A large interstitical deletion ecompassim the amelogenin gene on the short arm of the $y$ chromosome. Hum Genet. 2005;116(5):395-401.

Lee HC, Ladd C. Preservation and Collection of Biological Evidence. Croatian edical Journal. 2001; 42 (3):225 - 28.

Li S, Feng T, Fu L, Li Z, Lou C, Zhang X, et al. Pyrosequencing of a short fragment of the amelogenin gene for gender identification. Mol Biol Rep. 2012;39:6949-57.

Lima OC. Identificação odonto-legal do sexo [tese]. São Luís: Faculdade de Farmácia e Odontologia de São Luís; 1959.

Lindahl T. Instability and decay of the primary structure of DNA. Nature. 1993;362:709-15.

Lupta'kova' L, Ba' belova' A, Omelka R, Kolena B, Vondra'kova' M, Bauerova' M. Sex determination of early medieval individuals through nested PCR using a new primer set in the SRY gene. Forensic Sci Int. 2011;207:1-5.

Madeira MCM. Anatomia da face. $7^{a} \stackrel{e}{e}$ d. São Paulo: Sarvier; 2010.

Malaver PC, Yunis JJ. Different dental tissues as source of DNA for human identification in forensic cases. Forensic Sci. 2003;44(3):306-9.

Marjanovíc D, Durmic-Pasic A, Bakai N, Haveric S, Kovacevic L, Ramic J, et al. DNA identification of skeletal remains form World War II graves uncovered in Slovenia. Croat Med J. 2007;48:513-9.

Medina A, Braz CH, Moraes MP. Tragédia anunciada. [revista na internet]. Revista Veja. ed. № 1669 [acesso 10 jan 2010]. Disponível em:

http://vejabrasil.abril.com.br/rio-de-janeiro/editorial/m1669.

Meissner C, Bruse P, Mueller E, Oehmichen M. A new sensitive short pentaplex (ShoP) PCR for typing of degraded DNA. Forensic Sci Int. 2007;166:121-7. 
Meyer E, Wiese M, Bruchhaus $\mathrm{H}$, Claussen M, Klein A. extraction and amplification of authentic DNA form ancient human remains. Forensic Sci Int. 2000;13:87-90.

Michael A; Brauner P. Erroneous gender identification by the amelogenin sex test. J Forensic Sci. 2004;49:258-59.

Millar CD, Huynen L, Subramanian S, Mohandesan E, Lambert DM. New developments in ancient genomics. Trends Ecol Evolution. 2008;23(7):386.

Monticelli F, Graw M. Investigation on the reability of determining sex from the human zygomaticum. Forensic Med Sci Pathol. 2008;4(3):181-6.

Morikawa T, Yamamoto Y, Miyaishi S. A New Method for Sex Determination Based on Detection of SRY, STS and Amelogenin Gene Regions with Simultaneous Amplification of Their Homologous Sequences by a Multiplex PCR. Acta Med. Okayama. 2011;65(2):113- 2.

Morgan OW, Sribanditmongkol P, Perera C, Sulasmi Y, Alphen DV, Sondorp E. Mass fatality management following the South Asian tsunami disaster: case studies in Thailand, Indonsesia, and Sri Lanka. PLoS Med. 2006;3(6):809-15.

Morling N. PCR in forensic genetics. Biochem. Soc. Trans. 2009;37:438-440.

Mulero JJ, Chang CW, Lagacé RE, Wang DY, Bas JL, McMahon TP, et al. Development and validation of the AmpFISTR MiniFiler ${ }^{\text {TM}}$ PCR Amplification Kit: A MiniStr Multiplex for the Analysis of degraded and/or PCR Inhibited DNA. J Forensic Sci. 2008;53(4) 838-52.

Mundorff AZ, Bartelink EJ, Elaine Mar-Cash E. DNA Preservation in Skeletal Elements from the World Trade Center Disaster: Recommendations for Mass Fatality Management. J Forensic Sci. 2009 July; 54 (4):739-45.

Naikmasur VG, Shrivastava R, Mutalik S. Determination of sex in South Indian and immigrant Tibetans from cephalometric analysis and discriminant functions. Forensic Sci Int. 2010; 197:122 e1-122 e.6.

Nambiar $\mathrm{P}$, Jalil N, Singh B. The dental identification of victims of an aircraft accident in Malaysia. Int Dent J. 1997;47(1):9-15. 
Olinto MTA. Reflexões sobre o uso do conceito sexo e/ou sexo na epidemiologia: um exemplo nos modelos hierarquizados de análise. Rev Bras Epidemiol. 1998;1(2):161-9.

Oliveira RN, Daruge E, Galvão LCC, Tumang AJ. Contribuição da odontologia legal para a identificação "post-mortem". Rev Bras Odontol. 1998;55(2):117-22.

Oliveira RN, Daruge E, Daruge JR, Galvão LCC. Determinação do sexo através de mensurações mandibulares. Rev Assoc Brasil de Odontol. 1995;3:241-4.

Oliveira RN, Nunes FD, Anzai EK, Daruge E, Mesquita RA, Ozaki NA, et al. Population studies on the Y-chromossome of loci DYS390, DYS391 and DYS393 in Brazilian subjects and its use in human identification. J Forensic Odontostomatol. 2002;20(1):6-9.

Opel KL, Chung DT, Drabek J, Tatarek NE, Jantz LM, McCord BR. The application of miniplex primer sets in the analysis of degraded DNA from human skeletal remains. $J$ Forensic Sci. 2006;51(2):124-31.

Otto PG, Otto PA, Frota-Pessoa A. A genética humana e clínica. São Paulo: Roca; 1998.

Panella J. Estudo do dimorfismo sexual em nisseis e sanseis utilizando medidas lineares da mandíbula obtidas em pantomogramas. Rev Odontol Univ S Paulo. 1992 Jan-Jun.;6(1/2):19-23.

Paiva LAS, Segre M. Sexing the human skull through the mastoid process. Rev Hos Clín (FMUSP). 2003;58:15-20.

Patil KR, Mody RN. Determination of sex by discriminant function analysis and stature by regression analysis: a lateral cephalometric study. Int Sci Forense. 2004;147:175-80.

Peixoto A. Medicina legal. 3. ed. Rio de Janeiro: Francisco Alves; 1918.

Pfeiffer H, Huhne J, Seitz B, Brinkaman B. Influence of soil storage and exposure period on DNA recovery from teeth. Int J Legal Med.1999; 112(2):142- 4. 
Penna SDJ. O DNA como (única) testemunha em determinação de paternidade. Bioética. 1997;5:231-41.

Pereira CB, Alvin MCM. Manual para estudos craniométricos e cranioscópicos. Rio de Janeiro: Universidade Federal do Rio de Janeiro; 1978, p. 174.

Picapedra AMP. Determinação do gênero por meio do estudo dos maxilares [dissertação]. Piracicaba: Universidade Estadual de Campinas, Faculdade de Odontologia de Piracicaba; 2010.

Radicchi R. A odontologia legal e os Institutos Médicos Legais: uma parceria histórica. 2006 [acesso 27 dez 2009]. Disponível em: www.abo-ce.org.br.

Rai B. Role of Forensic Odontology in Tsunami Disasters. J For Sci [serial onthe internet]. 2007 [cited 2009 set 05]. Avaiable from:

http://www.ispub.com/journal/the_internet_journal_of_forensic_science/volume_2_nu mber_1_19/article/role_of_forensic_odontology_in_tsunami_disasters.html.

Ramalho SA, Daruge E, Meléndez BVLC, Francesquini MA, Pereira SDR. Francesquini Júnior L, et al. La importancia pericial del estudio comparativo histomorfológico del hueso humano y de otros géneros. REAd. Rev Eletrônica Adm. 2003; 60: 173- 9 [acesso 10 jan 2011]. Disponivel em:

HTTP://www.medigraphic.com/pdfs/adm/od-2003/0d035c.pdf.

Ramirez AIC. Estomatologia forense. 8ª̣ed. México: Trillas; 1990.

Ricaut FX, Tarcqui CK, Crubézy E, Ludes B. STR-genotyping form human medieval tooth and bone samples. Forensic Sci Int. 2005;151:31-5.

Rıos L, Ovejero JIC, Prieto JP. Identification process in mass graves from the Spanish Civil War I. Forensic Sci Internat. 2010;199:e27-e36.

Robinson MS, Bidmos MA. The skull and humerus in the determination of sex: reability of discriminat function equations. Forensic Sci Int. 2009; 186: 86.e1-86.e5. Rogers T. Determining the sex of human remains through cranial morphology. J Forensic Sci. 2005;50(3)1-8.

Rohland N, Hofreiter M. Ancient DNA extraction from bones and teeth. Nature protocols [serial on the internet]; 2007;2 (7);1756. [cited 2010 jun 10]. Avaiable from: natureprotocols / mo c. erutan. 
Rubio L, Martinz LJ, Martinez E, Heras SM. Study of short-and-long-term storage of teeth and its influence on DNA. J Forensic Sci. 2009;54(6):1411- 3.

Rudin N, Inman K. An introduction to forensic DNA analysis. $2^{\mathrm{a}}$ ed. Florida: CRC Press; 2002.

Sabancıog ulları V, Kosar MI, Salk I, Erdil FH, Oztoprak I, Cimen M. Diploe thickness and cranial dimensions in males and females in mid-Anatolian population: An MRI study. Forensic Sci Int. 2012;219:289.e1-289.e7.

Sagova- Mareckova M, Cermak L, Novotna J, Plhatkova K, Forstova J, Kopeck J. Innovative methods fos soil DNA purification tested in solis with widely differing characteristics. Appl Enviroment Microbiol.2008;74 (9):2902-7.

Saini V, Srivastava R, Rai RK, Shamal SN, Singh TB, Tripathi SK. An Osteometric Study of Northern Indian Populations for Sexual Dimorphism in Craniofacial Region. J Forensic Sci Int. 2011a;56(3):700-5.

Saini V, Srivastava R, Rai RK, Shamal SN, Singh TB, Tripathi SK. Mandibular Ramus: An Indicator for Sex in Fragmentary Mandible. J Forensic Sci. 2011b; 56(S1):S13-6.

Saini V, Srivastava R, Rai RK, Shamal SN, Singh TB, Tripathi SK. Sex Estimation from the Mastoid Process Among North Indians. J Forensic Sci. 2012;57(2):434-9.

Saliba CA. Contribuição ao estudo do dimorfismo sexual através de medidas do crânio [tese]. Piracicaba: Universidade Estadual de Campinas, Faculdade de Odontologia de Piracicaba; 1999.

Sampaio CMA. Investigação do sexo por mensurações crânio-faciais [tese]. Piracicaba: Universidade Estadual de Campinas, Faculdade de Odontologia de Piracicaba; 1999.

Santos LSM. Viabilidade da utilização de amostras biológicas obtidas de dentes humanos para obtenção de perfis genéticos de DNA [dissertação]. Piracicaba: Universidade Estadual de Campinas, Faculdade de Odontologia de Piracicaba; 2009. 
Santos JFM. Análise da amelogenina pulpar para determinação do gênero biológico [dissertação]. Piracicaba: Universidade Estadual de Campinas, Faculdade de Odontologia de Piracicaba; 2012.

Sassouni V. Dentofacial radiography in forensic dentistry. J Dent Res. 1963;42(1):274302.

Schmerer WM. Optimized DNA extraction from ancient human bones improves the reproducibility of STR genotyping of highly degraded ancient DNA. Technical Tips Online. 2001; 6 (1):41-45 [acesso 18 maio 2010]. Disponível em:

http://www.academia.edu/689285/Optimized_DNA_extraction_from_ancient_human bones_improves_the_reproducibility_of_STR_genotyping_of_highly_degraded_ancie nt_DNA

Schwartz TR, Schwartz EZ, Mieszerski L, McNally L, Kobilinsky L. Characterization of deoxyribonucleic acid (DNA) obtained from teeth subjected to various environmental conditions. J Forensic Sci. 1991;36(4):979-90.

Silva M. Compêndio de Odontologia legal. Rio de Janeiro: Medsi; 1997.

Silva M, Galvão LCC, Barros GB, Marques JAM._Investigação do sexo através da análise quantitativa do osso externo. Rev Med Legal Direito Méd Saúde.

2005;1(3):31-5.

Silva RHA, Oliveira RN. Forensic anthropology and molecular biology: independent or complementary sciences in forensic dentistry? An overview. Bras J Oral Sci. 2008;7(25):1575-9.

Sivagami AV, Rao AR, Varshey U. A simple and cost-effective method for preparing DNA from the hard tooth tissue, and its use in polymerase chain reaction amplification of amelogenin gene segment for sex determination in an Indian population. Forensic Sci Int.2000;110:107- 15.

Sjoholm MIL, Dillner J, Carlson J. Assessing quality and functionality of DNA from fresh and archival dried blood spots and recommendations for quality control guidelines. Clin Chem. 2007;53(8):1401-7.

Slauss M, Strinovíc D, Petrovecki V, Vyroubal V. Contribution of Forensic Anthropology to identification process in Croatia: examples of victims recovered in Wells. Croat Med J. 2007;48 503-12. 
Slavkin HC. Sex, enamel and forensic dentistry: a search for identity. J Am Dent Assoc. 1997;128:1021-5.

Smith BC, Holland MM, Sweet D, DiZinno JA. DNA and the forensic odontologist. In: Bowers CM, Bell GL. Manual of forensic odontology. 3rd ed. Colorado Springs: American Society of Forensic Odontology; 1997. p. 283-98.

Souza-Lima. Tratado de medicina-legal. 6ª ed., Rio de Janeiro:Freitas Bastos; 1938.

Spradley MK, Jantz RL. Sex Estimation in Forensic Anthropology: Skull Versus Postcranial Elements. J Forensic Sci. 2011;56(2):289-96.

Steyn M, Iscan MY. Sexual dimorphism in the crania and mandibles of South African Whites. Foensic Sci Int 1998; 98:9-16.

Steinlechner M, Berger B, Niederstätter H; Parson W. Rare failures in the amelogenin sex test. Int J Legal Med. 2002; 116:117-20.

Stone AC, Milner GR, Paabo S, Stoneking. Sex determination of ancient human skeletons using DNA. Am J Phys Anthropol. 1996;99:231-8.

Sweet D. Why a dentist for identification? Dent Clin North Am. 2001;45(2):237-51.

Sweet D, Hildebrand D. Recovery of DNA from human teeth by cryogenic grinding. $J$ Forensic Sci. 1998;43(6):1199-202.

Takayama T, Takada N, Suzuki R, Nagaoka S, Watanabe Y, Kumagai R, et al. Determination of deleted regions from Yp11.2 of an amelogenin negative male. Legal Med.2009;11:S578-S580.

Teixeira WRG. Medicina legal / Identificação médico-legal. São Paulo: s.e; 1978.

Tschentscher F, Frey UH, Bajanowski T. Amelogenin sex determination by pyrosequencing of short PCR products. Int J Legal Med. 2008;122:333-35. Turrina S, Filippini G, Voglino G, De Leo D.. Two additional reports of deletion on the short arm of the $Y$ chromosome. Forensic Sci Internat: Genetics.2011;5:242-6.

Tuross N. The biochemistry of ancient DNA in bone. Experientia. 1994;50 530-5. 
Urbani C, Lastrucci RD, Kramer B. The effect of temperature on sex determination using DNA- PCR analysis of dental pulp. J Forensic Odontostomatol. 1999;17(2):359.

Uytterschaut HT. Sexual dimorphism in human skulls. A comparison of sexual dimorphism in different populations. Human Evolution. 1986;1(3):243-50.

Valdrighi M, Ambrosano G, Francesquini-Jr L et al. Determinación del sexo por las medidas lineares de la cara y su importancia pericial. RAOA. 2003;91(4):279-82.

Valenzuela A, Martin-de-las-Heras S, Marques T, Exposito N, Bohoyo JM. The application of dental methods of identification to human burn victims in a mass disaster. Int J Legal Med. 2000;113:236-9.

Valenzuela A, Marques T, Exposito N, Martín-de-las-Heras S, García G. Comparative study of efficience of dental methods for identification of burn victims in two bus accidents in Spain. Am J Forensic Med Pathol. 2002;23(4):390-3.

Vanek D, SAskova L, Koch H. Kinship and Y-Chromosome Analysis of 7th Century Human Remains: Novel DNA Extraction and Typing Procedure for Ancient Material. Croat Med J. 2009;50(3):286-95.

Vanrel JP. Odontologia legal e antropologia Forense. 2 ed.São Paulo: Guanabara Koogan; 2009.

Velarde-Félix JS, Molina-Benítez CE, Solórzano-Rosales SR, Cázarez-Salazar SG, Rendón-Aguilar H, Murillo-Llanes J, et al. Identificación del sexo mediante análisis molecular. Rev Mex Patol Clin. 2008; 55(1):17-20.

Vieira GS, Tavares CAP, Bouchardet FCH. Análise de DNA em odontologia forense. Arqu Bras Odontol. 2010;6(2):64-70.

Walker PL. Sexing skulls using dicriminant function analysis of visually assessed traits. Am J Phys Anthropol. 2008;136:39-50.

Whall J, Henke W. Die pars petrosa als diagnostikum für die multivariate-biometrisch geschlechtsbestimmung von leichenbrandmaterial. Z Morphol Anthropol. 1980;70:258-68. 
Weber JL. Human diallelic insertion/deletion polymorphisms. Am J Hum Genet. 2002;71:854- 62.

Williams BA, Rogers TL. Evaluating the accuracy and precision of cranial morphological traits for sex determination. J Sci Forense. 2006;51:729-35.

Woide D, Zink A, Thalhammer S. Technical Note: PCR Analysis of Minimum Target Amount of Ancient DNA. Am J Phys Anthropol. 2010;142:321-7.

Yoshida M, Suno M, Asari M, Ogawa K, Awaya T, Shimizu K et al. Sex identification form DNA in old teeth. Hokkaido Igaku Zasshi. 2005;80(2):191-9.

Zavando MDA, Suazo GIC, Smith RJ. Sexual dimorphism determination from linear dimensions of skull. Int J Morphol. 2009; 27(1):133-7.

Zorzetto R. A África nos genes do povo brasileiro. Pesquisa Fapesp. Abril/2007.[acesso 10 jan 2010]. Disponível em:

http://revistapesquisa2. fapesp.br/?art=3193\&bd=1\&pg=1 . 
ANEXO A - Autorização do Centro de Estudo e Pesquisa em Ciências Forenses - Guarulhos

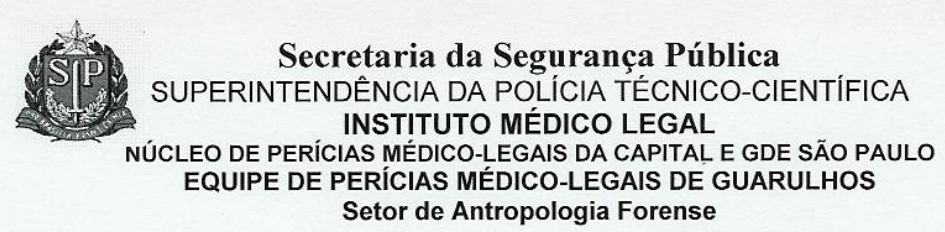

São Paulo, 29 de junho de 2010

AUTORIZAÇÃO

Autorizo a Prof. Dr. Rogerio Nogueira de Oliveira a tomar medidas craniométricas e obter material genético (DNA) dos dentes dos 60 (sessenta) crânios em coleção, sob guarda deste Serviço, com o objetivo de realizar pesquisa científica intitulada "ESTUDO ESTIMATIVO DO SEXO EM CRÂNIOS ORIUNDOS DA REGIÃO DE GUARULHOS - SP UTILIZANDO ANTROPOLOGIA FÍSICA E DNA".

Dr. Lurz Airton Saavedra de Paiva Responsáxel pelo Setor de Antropologia Forense

Instituto Médico Legal de Guarulhos 


\section{ANEXO B- Autorização do Laboratório de DNA de Genética do HRACF (Centrinho)}
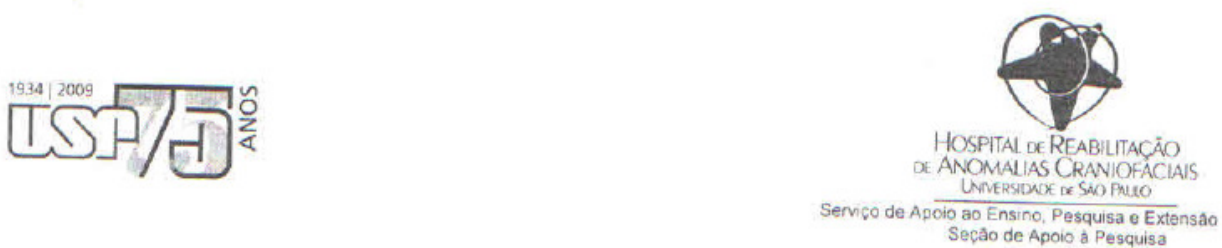

São Paulo, 24 de agosto de 2010.

\section{AUTORIZAC̄̃̃O}

Autorizo o Prof. Dr. Rogério Nogueira de Oliveira e a aluna Suzana Papile Maciel Carvalho a realizarem parte da pesquisa "Estudo estimativo do sexo em crânios oriundos da região de Guarulhos - SP utilizando antropologia fisica e DNA" no laboratório de Genética do Hospital de Reabilitação de Anomalias Crânio-faciais de Bauru, USP. O trabalho tem como autores Rogério Nogueira de Oliveira, Suzana Papile Maciel Carvalho, Luiz Airton Saavedra de Paiva e Lucilene Arilho Ribeiro Bicudo. Será realizada nesse laboratório a análise por DNA dos elementos dentários e do osso coletado dos esqueletos do Instituto Médico Legal de Guarulhos.

Nesta oportunidade aproveito para reiterar a V.Ex. ${ }^{a}$ meus protestos de elevada estima $\mathrm{e}$ consideração.

Atenciosamente,

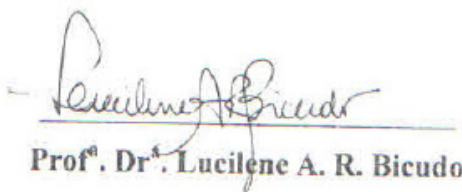

Responsável pelo Laboratório de Genética do HRAC-USP. 


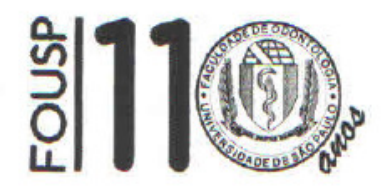

\author{
UNIVERSIDADE DE SÃO PAULO \\ FACULDADE DE ODONTOLOGIA \\ COMTTE DE ÉTICA EM PESQUISA
}

\author{
PARECER DE APROVAÇÃO \\ $F R-365970$ \\ Protocolo 138/2010
}

\begin{abstract}
O grupo de trabalho indicado pelo Comitê de Ética em Pesquisa APROVOU o protocolo de pesquisa "Estudo estimativo do sexo em crânios oriundos da regiâo de Guarulhos - SP utilizando antropologia física e DNA", de responsabilidade do(a) Pesquisador(a) Suzana Papile Maciel Carvalho, Prof. Dr. Luiz Airton Saavedra de Paiva, Profa.Dra. Lucilene Arilho Ribeiro Bicudo, sob orientaçăo do(a) Prof.(a) Dr.(a) Rogerio Nogueira Oliveira.

Tendo em vista a legislação vigente, devem ser encaminhados a este Comitê relatórios anuais referentes ao andamento da pesquisa e ao término cópia do trabalho em "cd". Qualquer emenda do projeto original deve ser apresentada a este CEP para apreciação, de forma clara e sucinta, identificando a parte do protocolo a ser modificada e suas justificativas.
\end{abstract}

São Paulo, 23 de setembro de 2010.

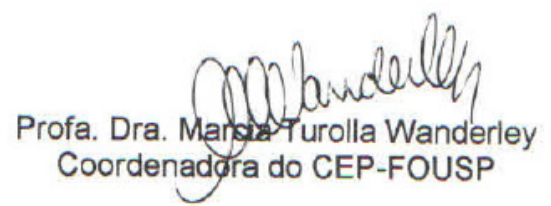

Av. Prof. Lineu Prestes, 2227 - Cidade Universitária "Armando de Salles Oliveira" São Paulo - SP - CEP 05508-900 -Tel. (0XX11) 3091-7960 
ANEXO D- Ficha para Registro das medidas e parâmetros avaliados

Pesquisa: Estudo estimativo do sexo em crânios oriundos da região metropolitana de Guarulhos utilizando Antropologia Física e DNA.

Faculdade de Odontologia de São Paulo - USP.

Serviço de Antropologia Forense do Instituto Médico Legal de Guarulhos.

Dados da ossada:

Número da ordem:

Nome:

Sexo: Raça: idade: statura: Peso:

Data nascimento: Local de nascimento:

Profissão: Tipo sanguíneo:

Data de falecimento: Causa do falecimento:

Data da Inumação: Data da exumação: Período de inumação:

\section{Análise Somatoscópica}
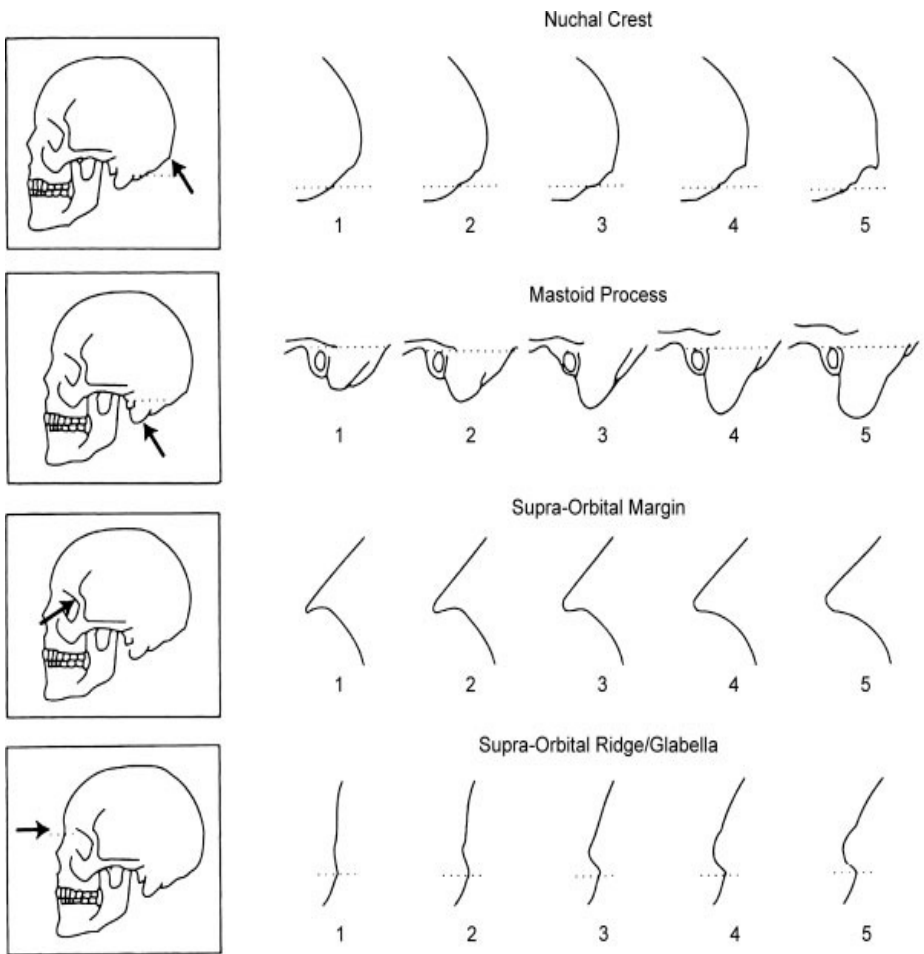

Supra-Orbital Ridge/Glabella
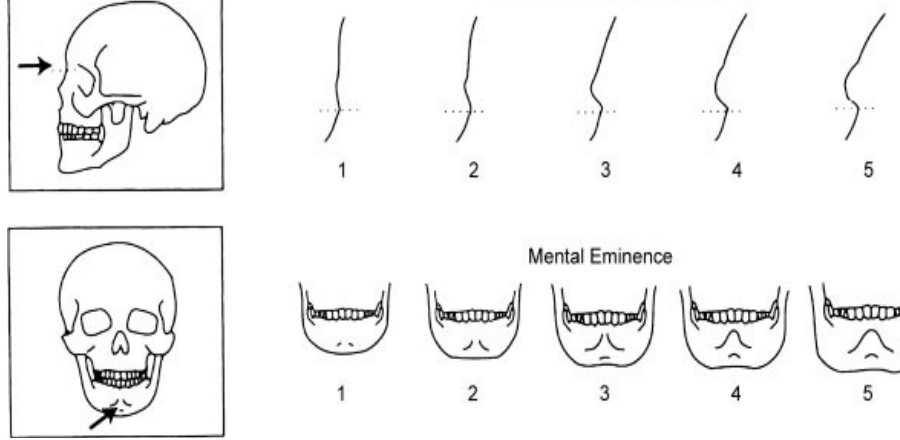

Mental Eminence

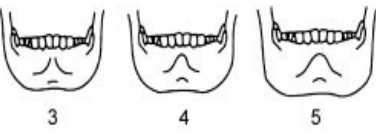


2. Metodologia de Oliveira

\begin{tabular}{|l|l|l|}
\hline Tipo de mensuração & Direita & Esquerda \\
\hline Distância bigoníaca (FDB 28) (go-go) & & \\
\hline Largura mínima do ramo mandibular (FDB 30) & & \\
\hline Altura do ramo mandibular (FDB 32) & & \\
\hline Comprimento total da mandíbula (FDB 33) & & \\
\hline
\end{tabular}

3. Metodologia do Forensic Antropology Data Bank (FDB)

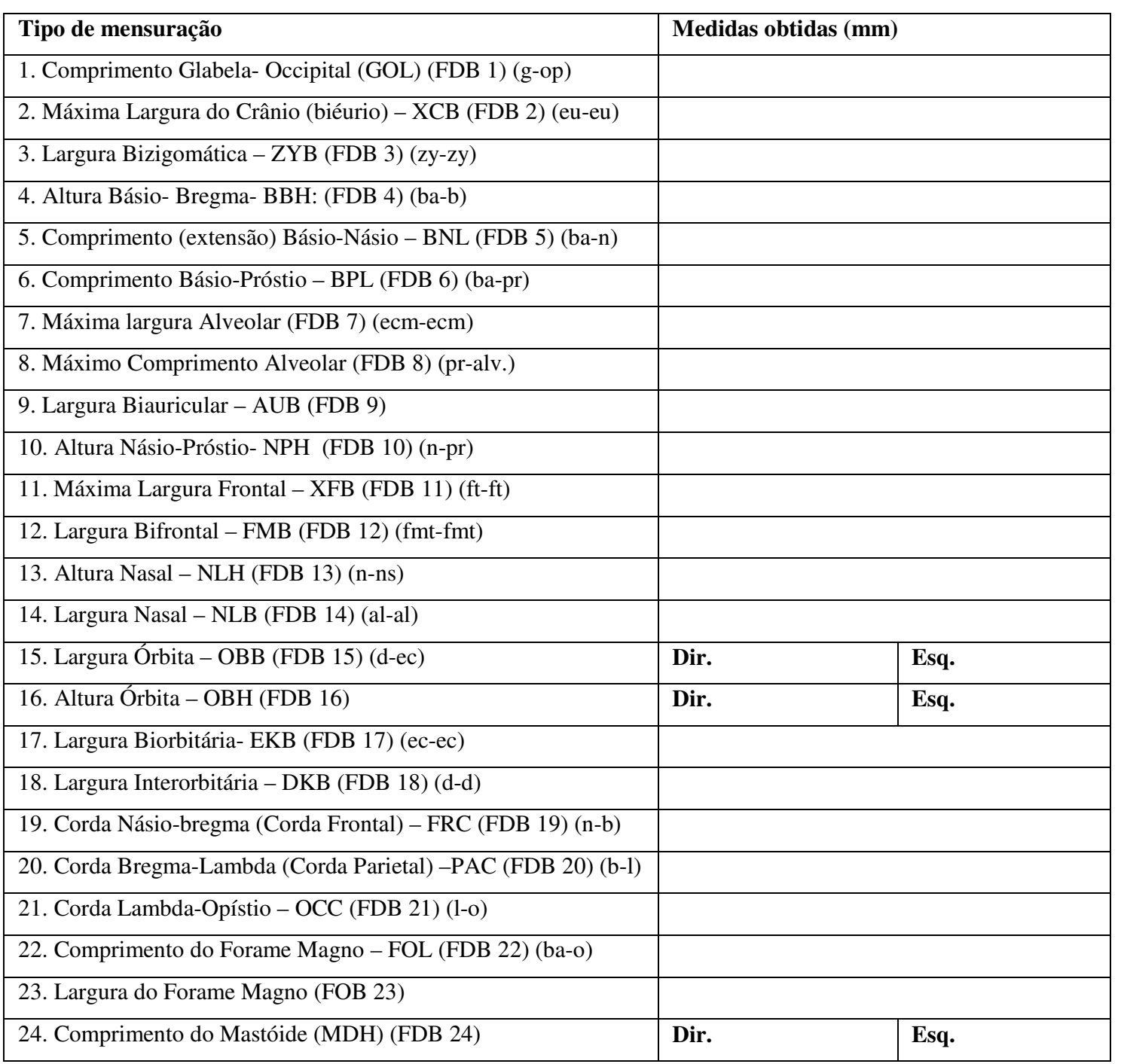

\begin{tabular}{|l|l|l|}
\hline & Direita & Esquerda \\
\hline 25. Altura do queixo (gn-id) (FDB 25) (gn-id) & & \\
\hline 26. Altura do corpo no forame mentoniano (FDB 26) & & \\
\hline 27. Espessura do corpo da mandíbula (FDB 27) & & \\
\hline 28. Largura Bicondilar (cdl-cdl) (FDB 29) (dcl-cdl) & & \\
\hline 29. Largura máxima do ramo mandibular (FDB 31) & & \\
\hline 30. Ângulo Mandibular (FDB 34) & & \\
\hline
\end{tabular}


ANEXO E - Fotos das Medidas do FDB (1986)

1. Maximum Length (Comprimento Máximo do Crânio) (g-op): Distância em linha reta que vai da glabela ao occipital. Ponto Glabela: na região frontal mediana, entre os arcos superciliares. Ponto Occipital: no extremo posterior do diâmetro longitudinal máximo do crânio, sobre a parte cerebral da escama occipital.

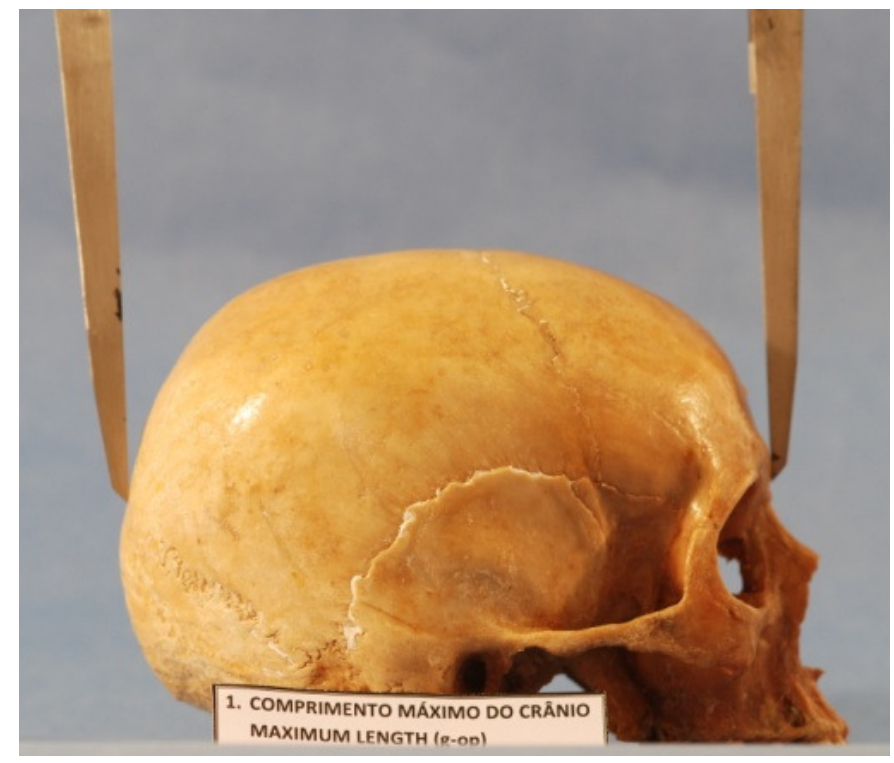

2. Maximum Breadth (Largura Maxima do Crânio) (eu-eu): Distância em linha reta interposta a um e outro ponto éurio. Ponto éurio: no extremo do diâmetro transverso máximo do crânio, sobre o túber parietal.

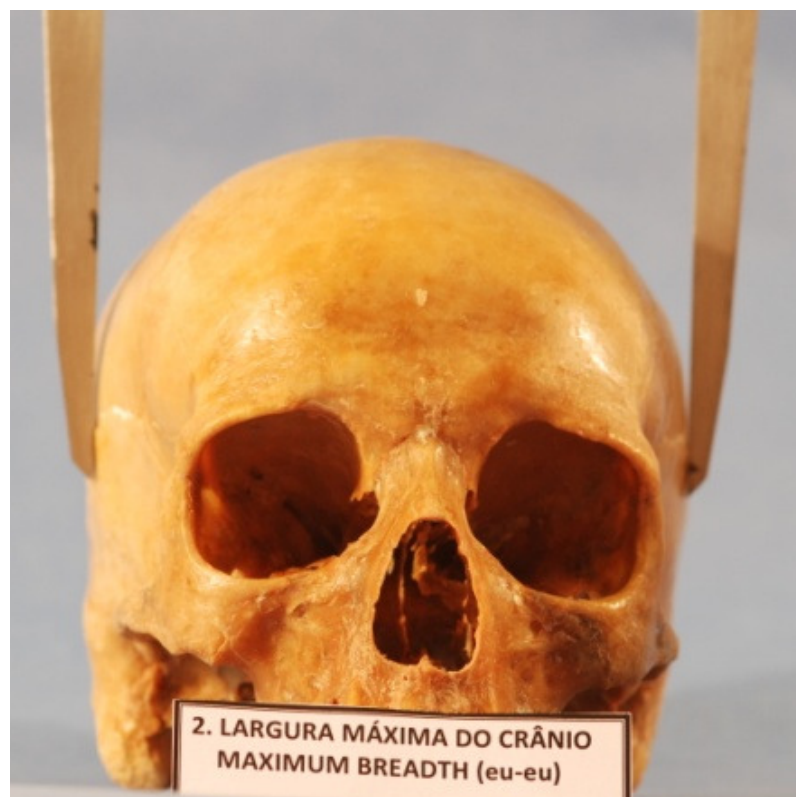


3. Bizygomatic breadth (Largura Bizigomática) (zy-zy): Distância, em linha reta, que separa um zigomático de outro, correspondente à largura total da face. Ponto zígio: na parte mais saliente da face externa do osso zigomático.

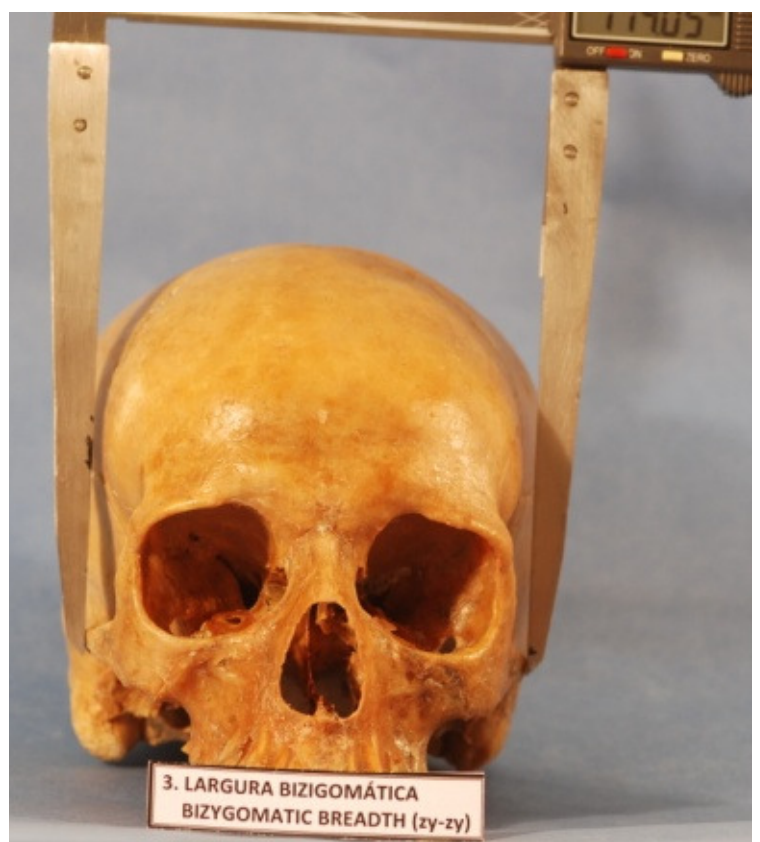

4. Basion- Bregma (Altura Básio- Bregma) (ba-b): Distância em linha reta, do ponto básio ao ponto bregma. Ponto bregma: onde se encontram as suturas coronal e sagital.

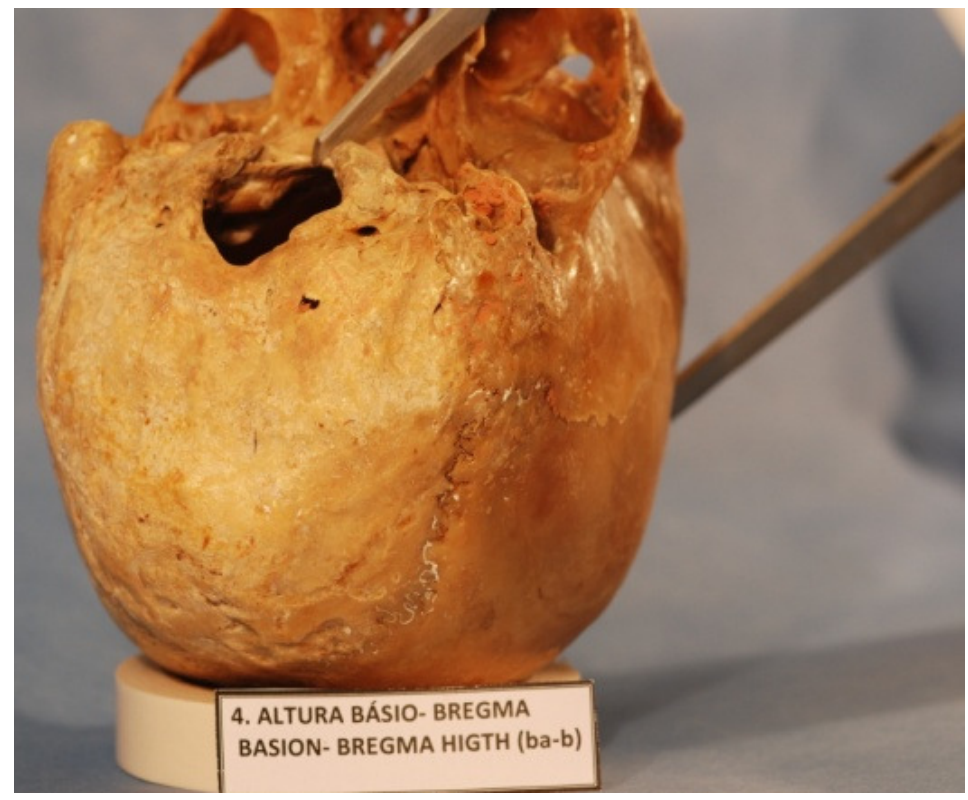


5. Cranial Base Length (Comprimento Básio-Násio) (ba-n): Distância em linha reta que vai do ponto básio ao ponto násio. Ponto básio: na margem anterior do forame magno.

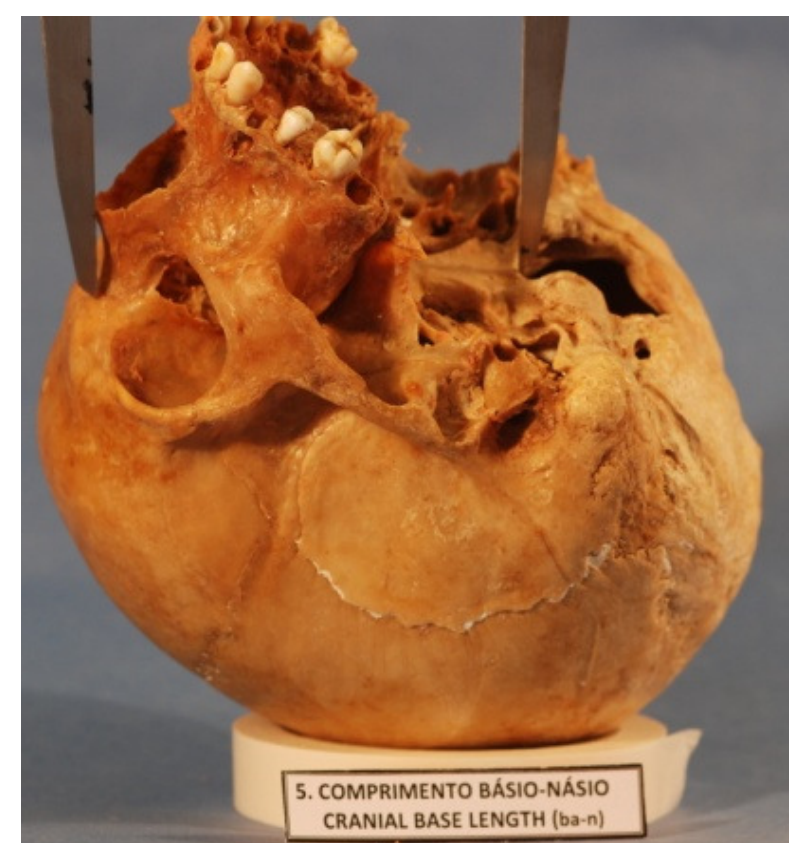

6. Basion- Prosthion Length (Comprimento Básio-Próstio) (ba-pr): Distância em linha reta entre os pontos básio e próstio. Ponto próstio: no processo alveolar superior, sobre a sutura intermaxilar.

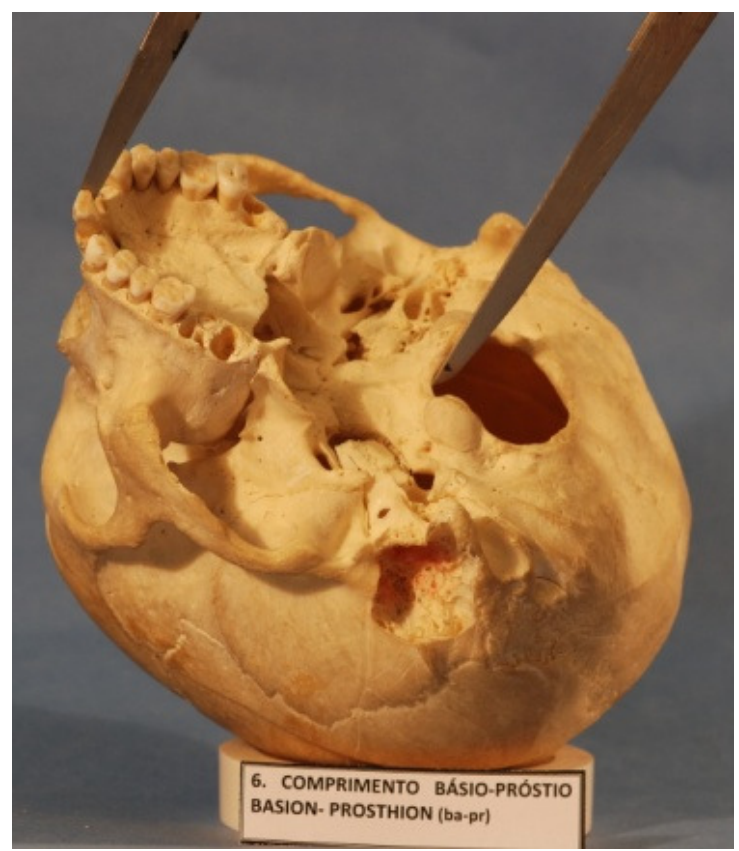


7. Maximum Alveolar Breadth (Máxima Largura Alveolar) (ecm-ecm): Distância em linha reta interposta a um e outro ponto ectomolar.

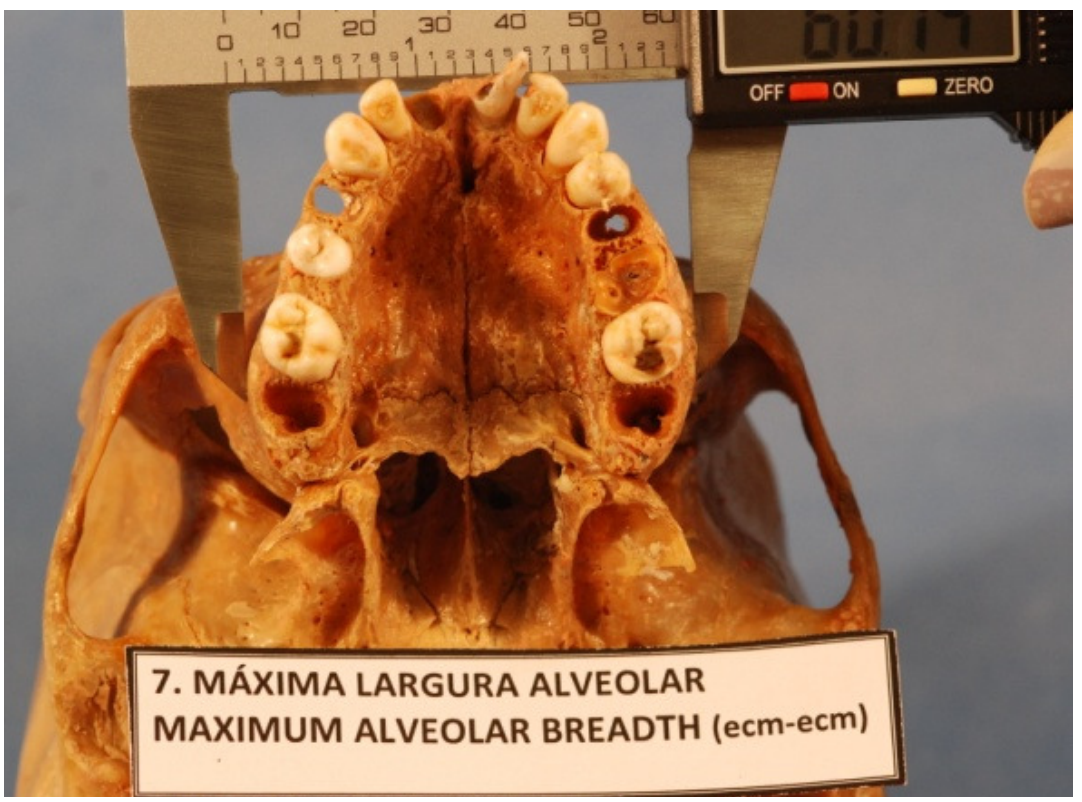

8. Maximum Alveolar Length (Máximo Comprimento Alveolar) (pr-alv): Distância entre o ponto próstio e o ponto alveolar. Ponto próstio: no processo alveolar superior, sobre a sutura intermaxilar.Ponto alveolar: Ponto de encontro da linha média do palato com a perpendicular que tangencia a borda posterior da arcada alveolar.

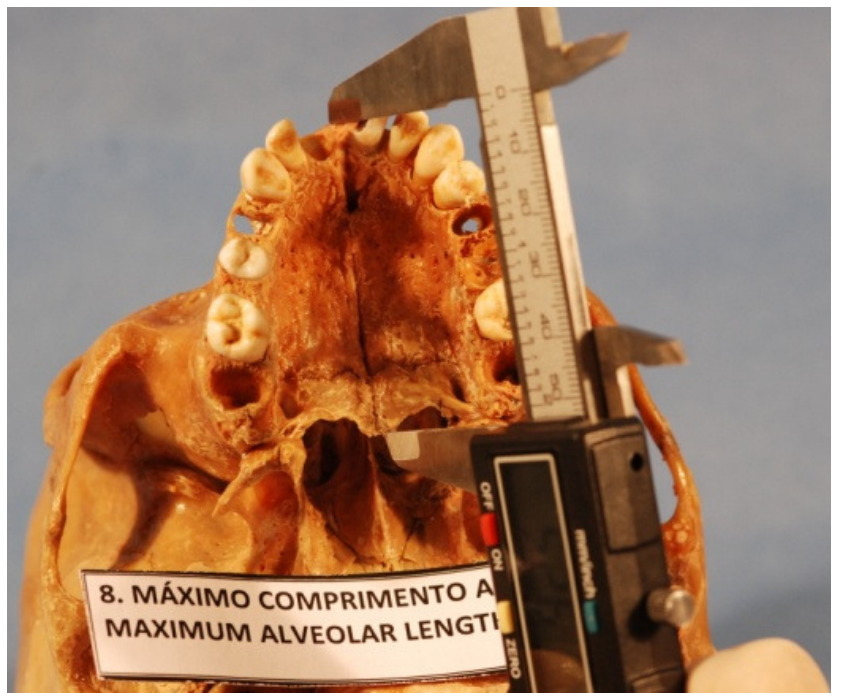


9. Biauricular Breadth (Largura Biauricular) (AUB): Distância, em linha reta, que separa o ponto auricular de um lado do ponto simétrico do lado oposto. Ponto auricular: na entrada do conduto auditivo externo.

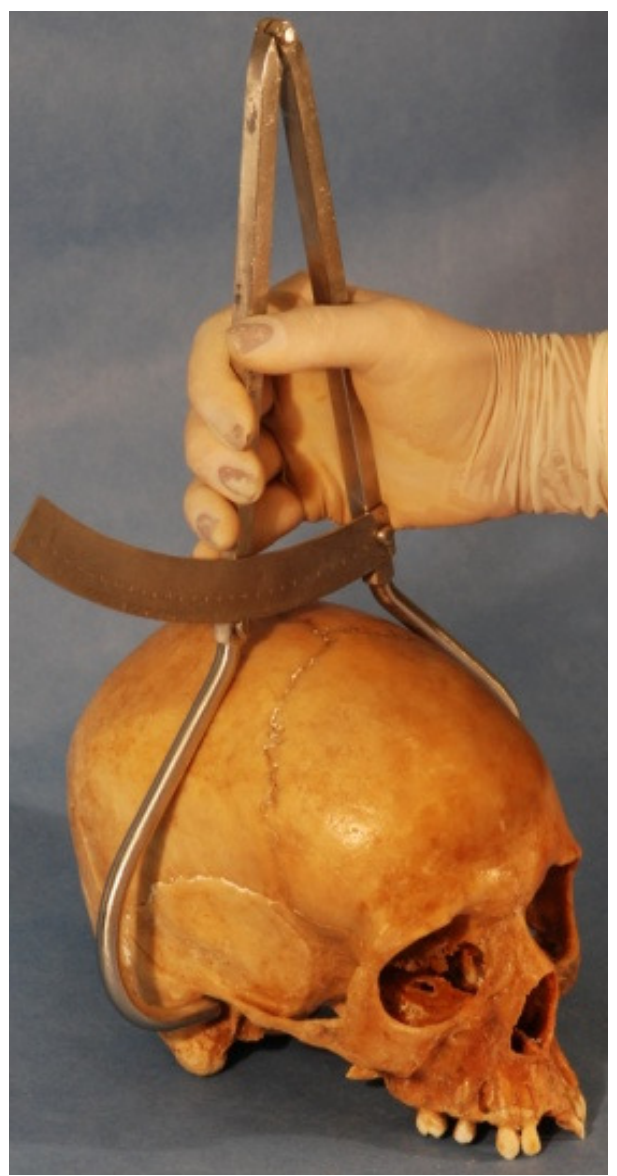

10. Upper Facial Higth (Altura Facial Superior) (n-pr): Distância em linha reta entre os pontos násio e próstio.

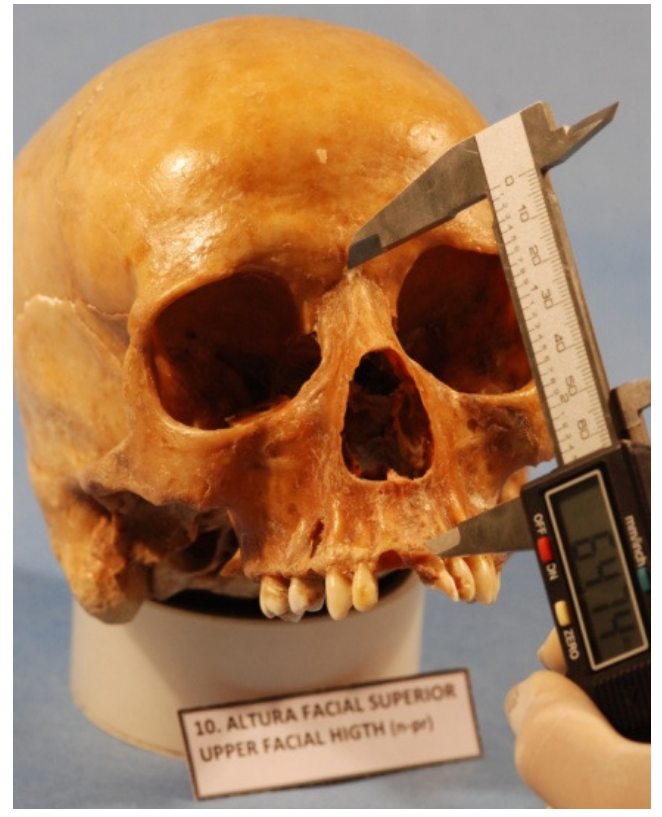


11. Minimal Frontal Breadth (Mínima Largura Frontal) (ft-ft): Distância, em linha reta, entre pontos fronto-temporal de ambos os lados. Ponto fronto-temporal: sobre a crista lateral do frontal, no extremo do diâmetro frontal mínimo.

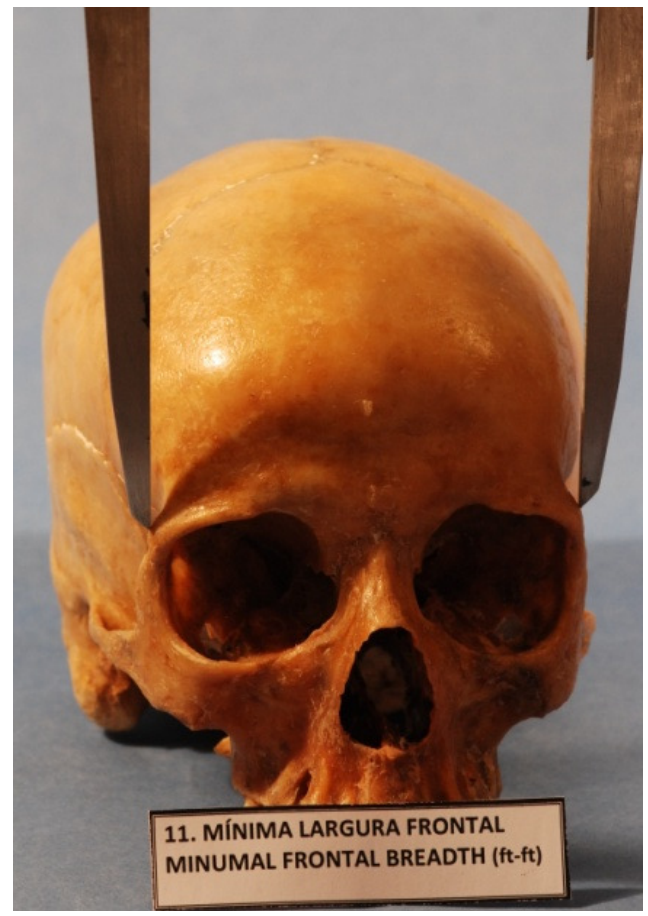

12. Upper Facial Breadth (fmt-fmt) (Largura Facial Superior): Largura através de todo osso frontal entre o fronto-malar de cada lado. Ponto fronto-malar: ponto mais anterior da sutura fronto-malar.

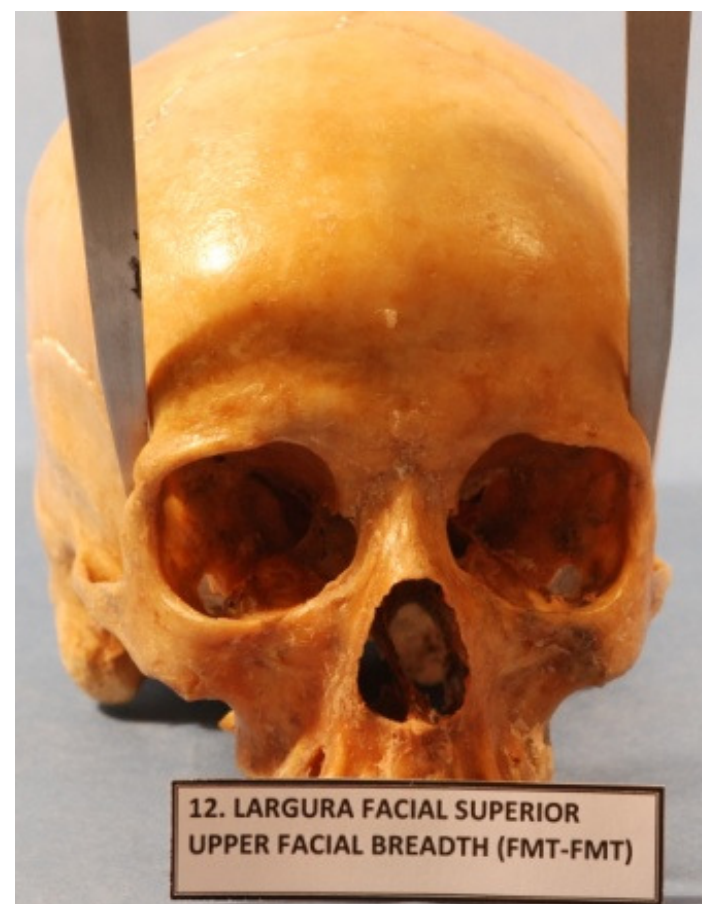


13. Nasal Heigth (n-ns) (Altura Nasal): Altura média do násio ao ponto mais baixo na borda da abertura nasal em ambos os lados.

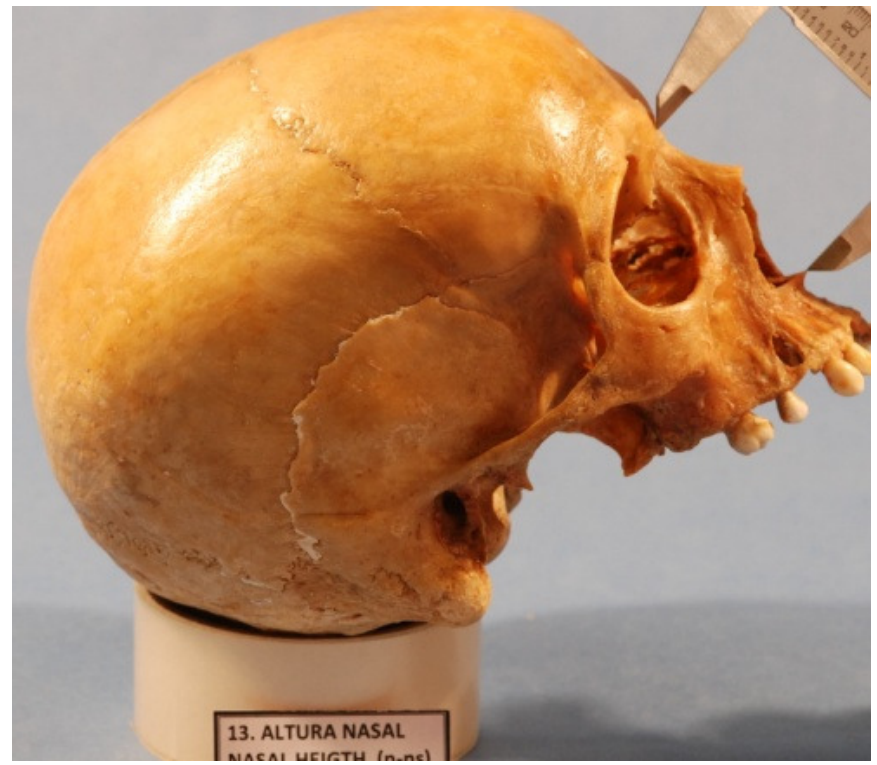

14. Nasal Breadth (Largura Nasal) (al-al): Distância máxima existente entre as bordas externas das asas do nariz (abertura nasal), de um lado ao outro.

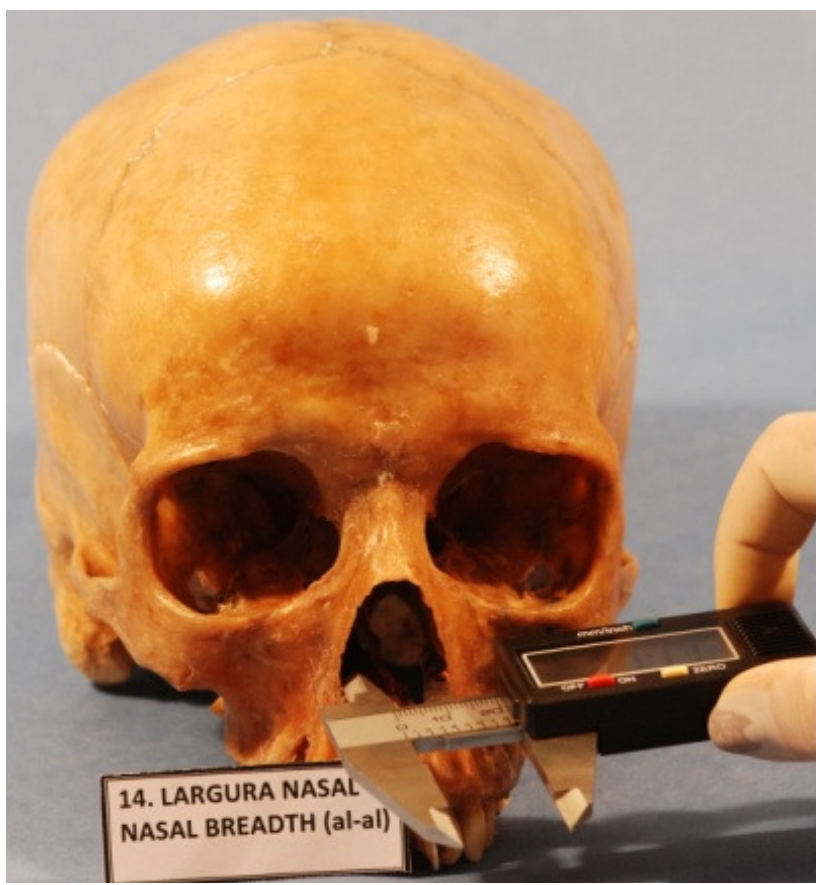


15. Orbital Breadth (Largura Orbitária) (d-ec): Largura do ectocântio ao dácrio, definida como aproximadamente o eixo longitudinal que corta a órbita em partes superior e inferior iguais. Ectocântio: a intersecção da superfície mais anterior da borda lateral da órbita e a linha que atravessa a órbita ao longo do seu eixo longitudinal. Ponto Dácrio: o ápice da fossa lacrimal que colide com o osso frontal, na parte interna da cavidade orbitária.

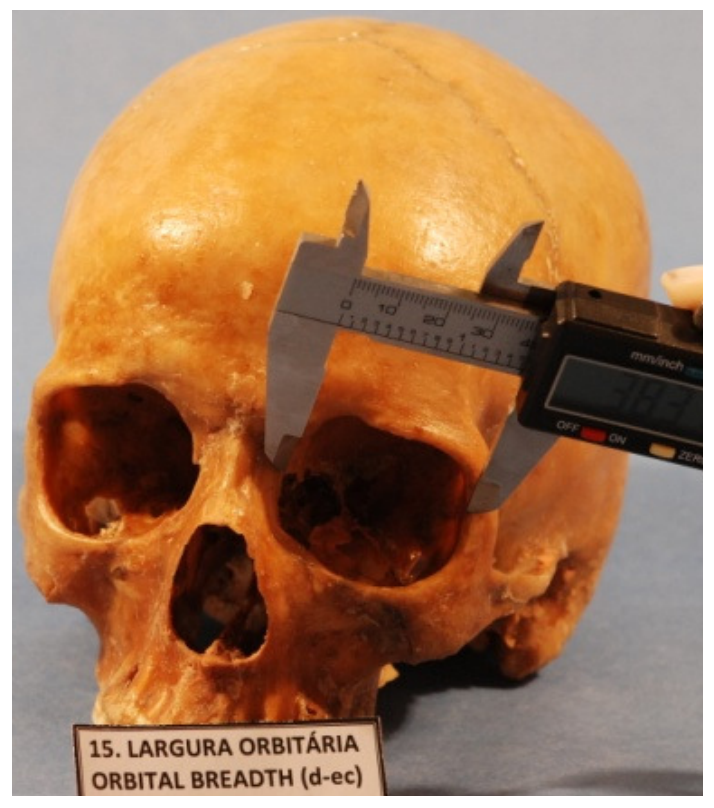

16. Orbital Heigth (Altura Órbita) (OBH): Altura entre as bordas superior e inferior da órbita esquerda, perpendicular ao longo eixo da órbita e à sua bissetriz.

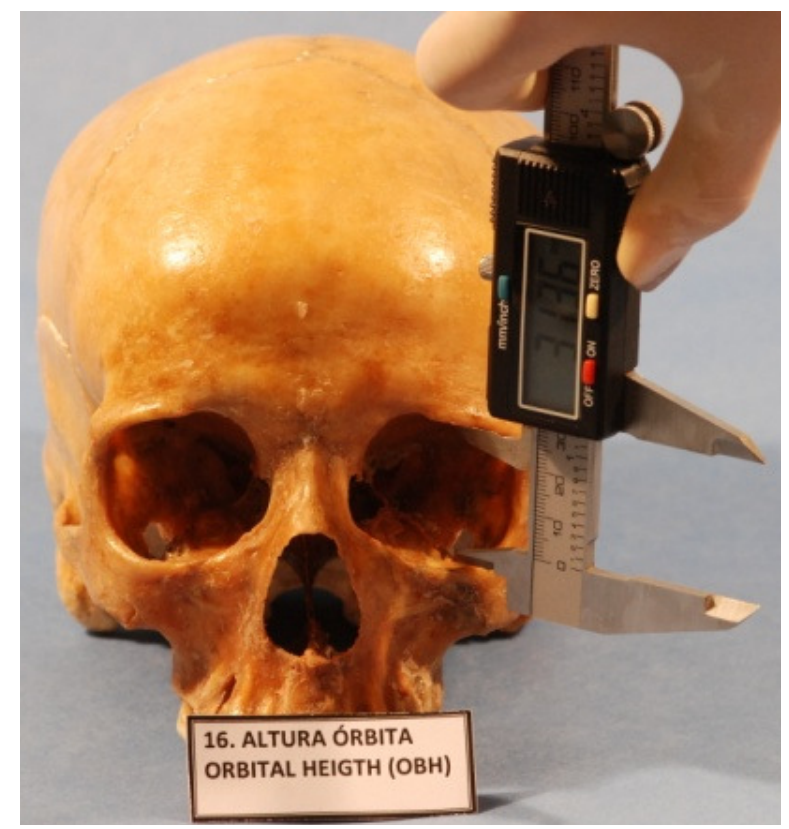


17. Biorbital Breadth (Largura Biorbitária) (ec-ec): Distância interposta entre os dois pontos ectocântios, ou seja, entre os pontos mais extremos e externos das órbitas, formando uma linha reta entre as órbitas esquerda e direita.

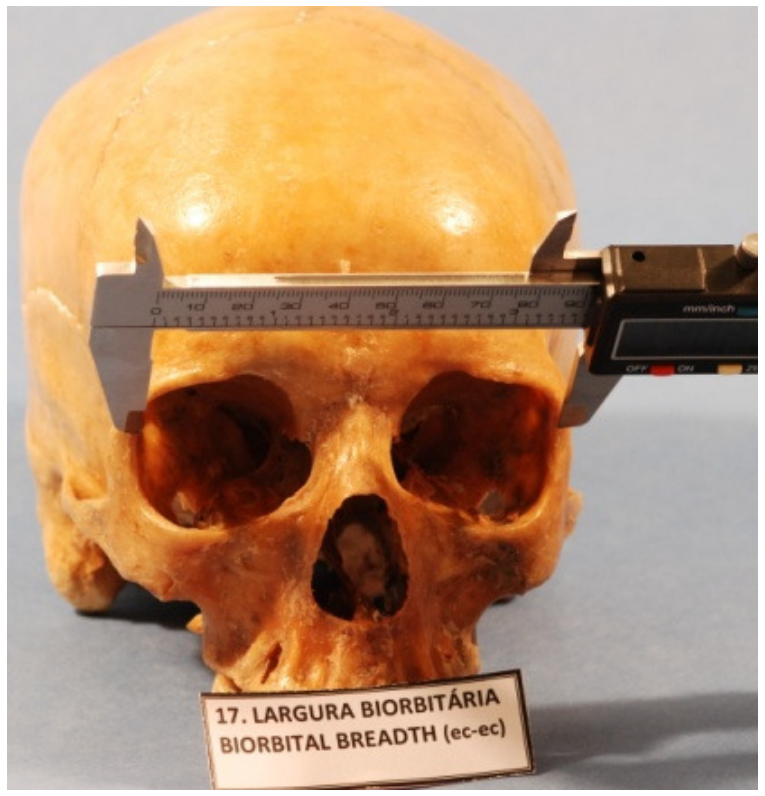

18. Interorbital Breadth (Largura Interorbitária) (d-d): a largura entre o espaço nasal, de um ponto dácrio ao do lado oposto.

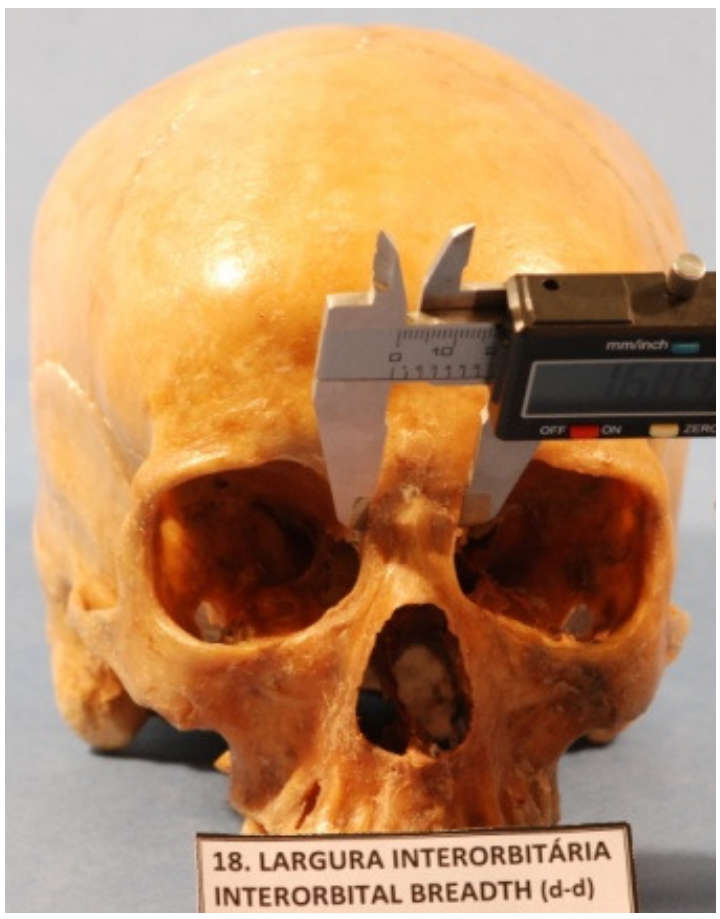


19. Frontal Chord (Corda Frontal) (n-b): Corda frontal ou a distância direta do ponto násio ao ponto bregma, tomada no plano mediano e na superfície externa.

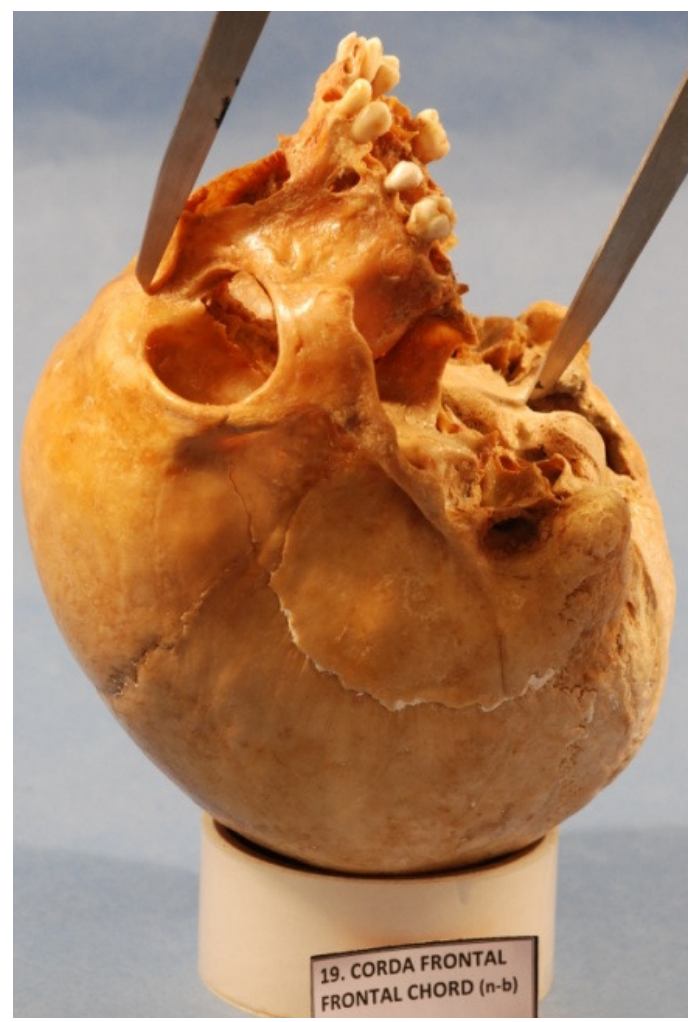

20. Parietal Chord (Corda Parietal) (b-l): Corda externa ou distância direta do bregma ao lambda, tomada no plano mediano e na superfície externa.

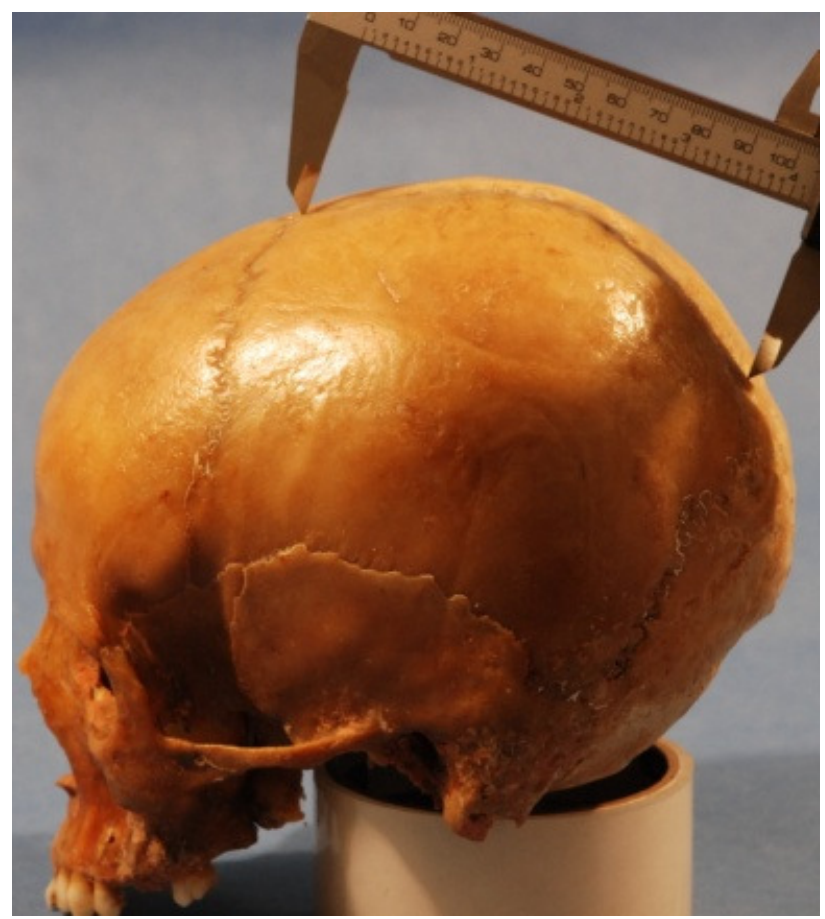


21. Occipital Chord (Corda Occipital) (I-o): Corda occipital externa ou distância direta do lambda ao opístio, tomada no plano mediano e na superfície externa.

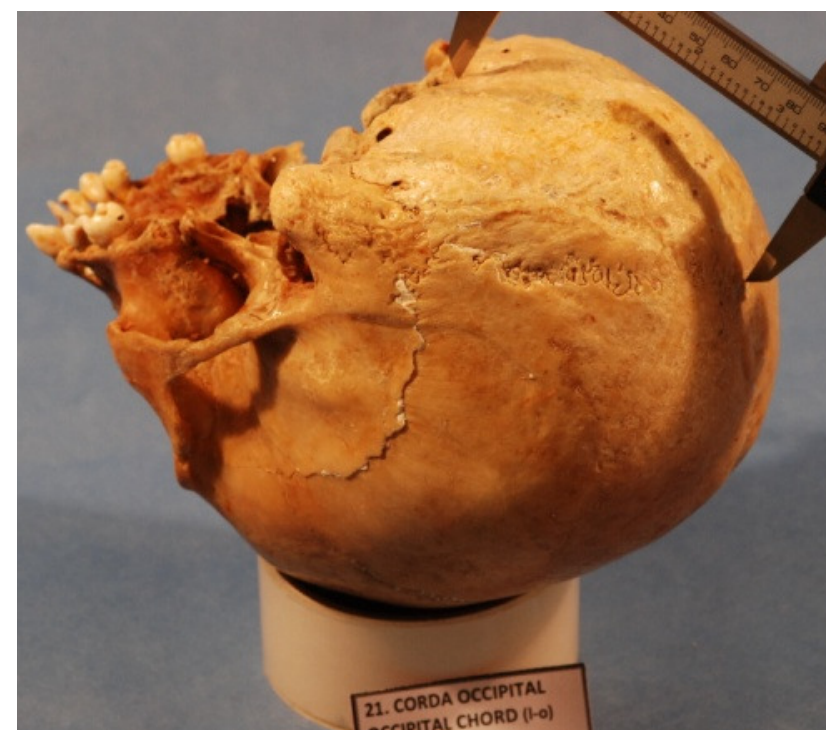

22. Foramen Magnum Length (Comprimento do Forame Magno) (ba-o): Distância ântero-posterior do forame magno, ou seja, a distância do básio ao opístio, em linha reta.

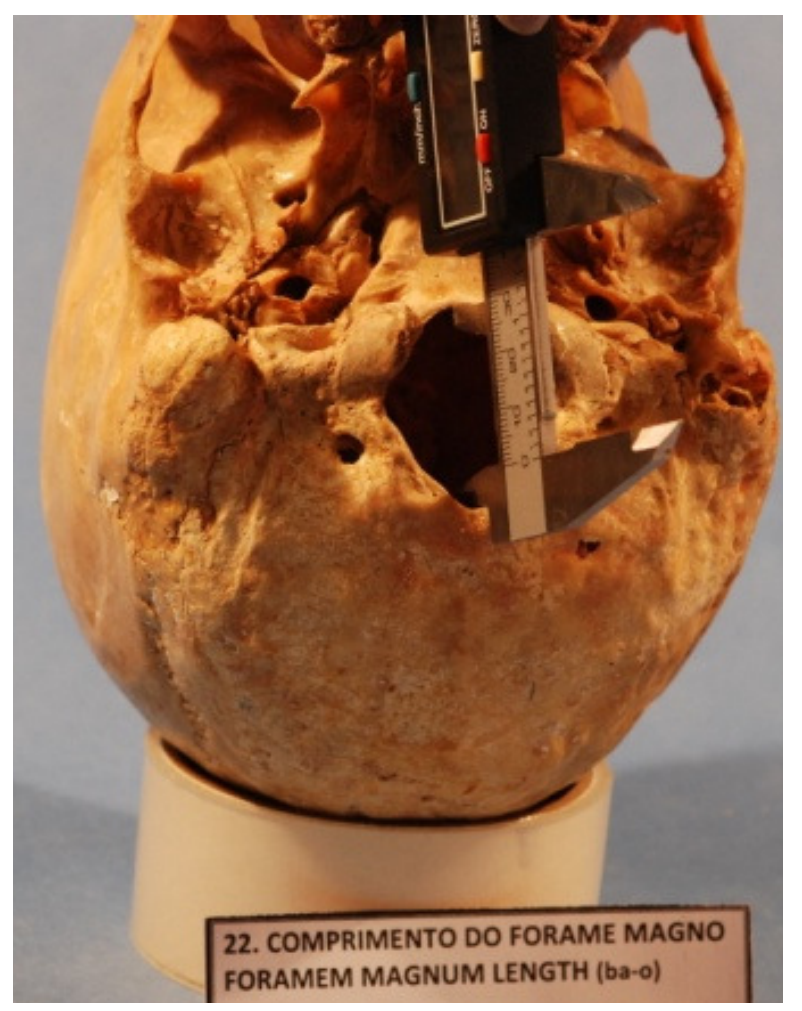


23. Foramen Magnum Breadth (Largura do Forame Magno) (FOB): Maior distância entre as bordas laterais do forame magno.

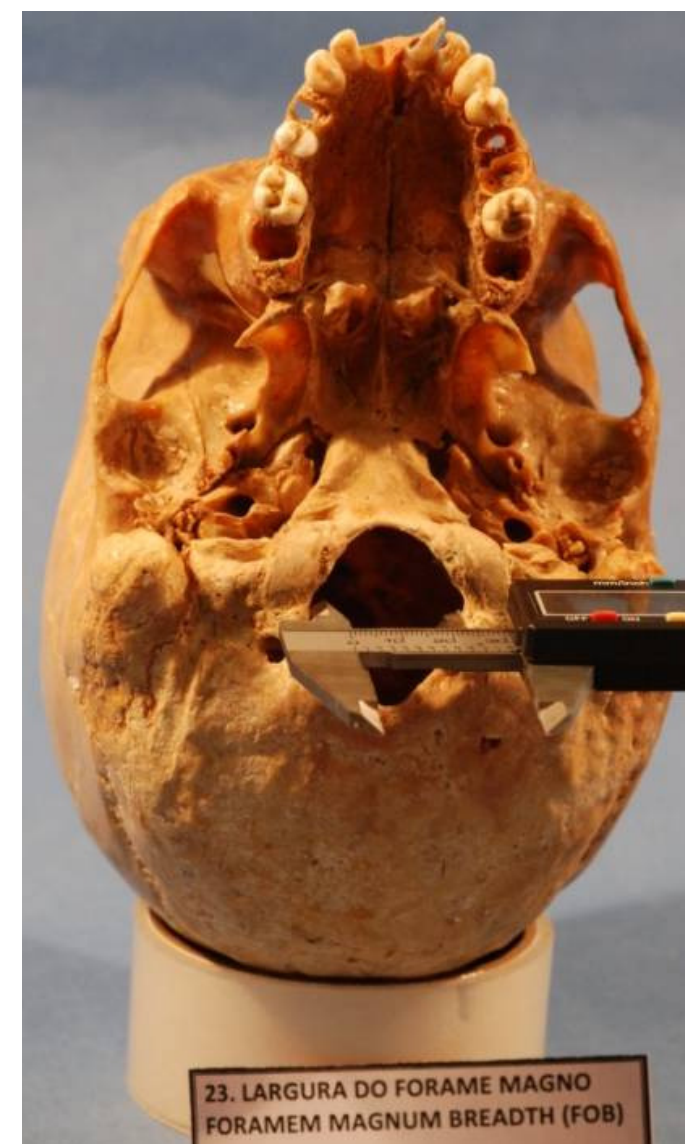

24. Mastoid Length (Comprimento do Mastoide) (MDH): Altura do processo mastóide, perpendicularmente ao plano orelha-olho, no plano vertical.

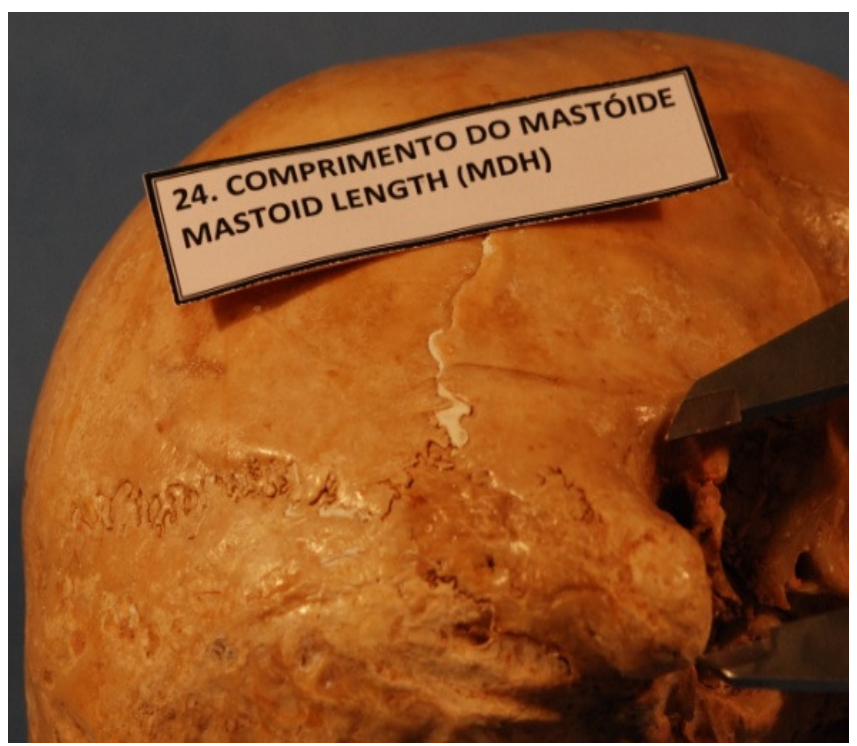


25. Chin Heigth (Altura do queixo) (gn-id): Distância entre os pontos gnátio e infradentário. Ponto infradentário: Ponto localizado no bordo alveolar anterior entre os incisivos centrais inferiores.

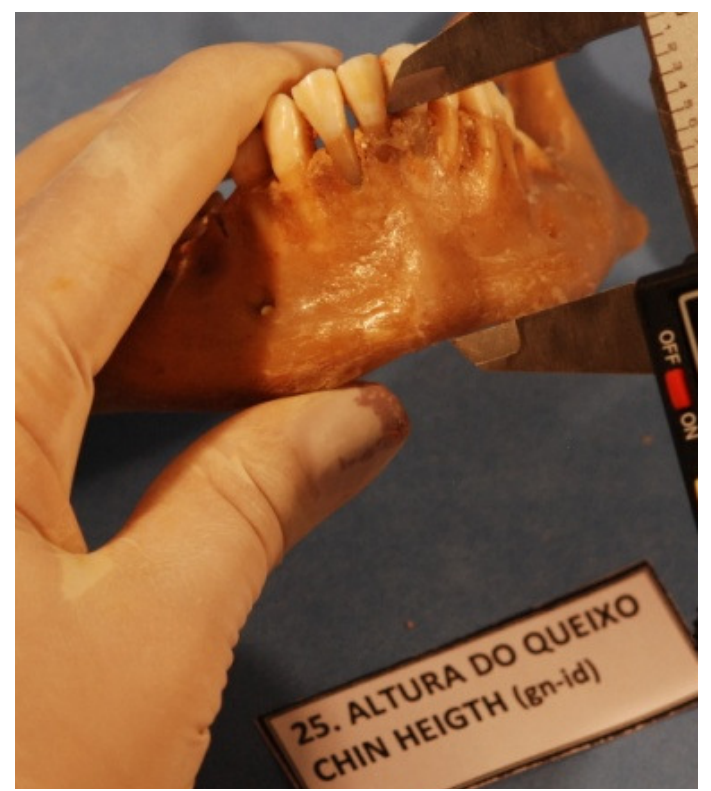

26. Body Height at Mental Forame (Altura do Corpo da Mandíbula no Forame Mentoniano): Distância entre o rebordo alveolar e a base da mandíbula na altura do forame mentoniano.

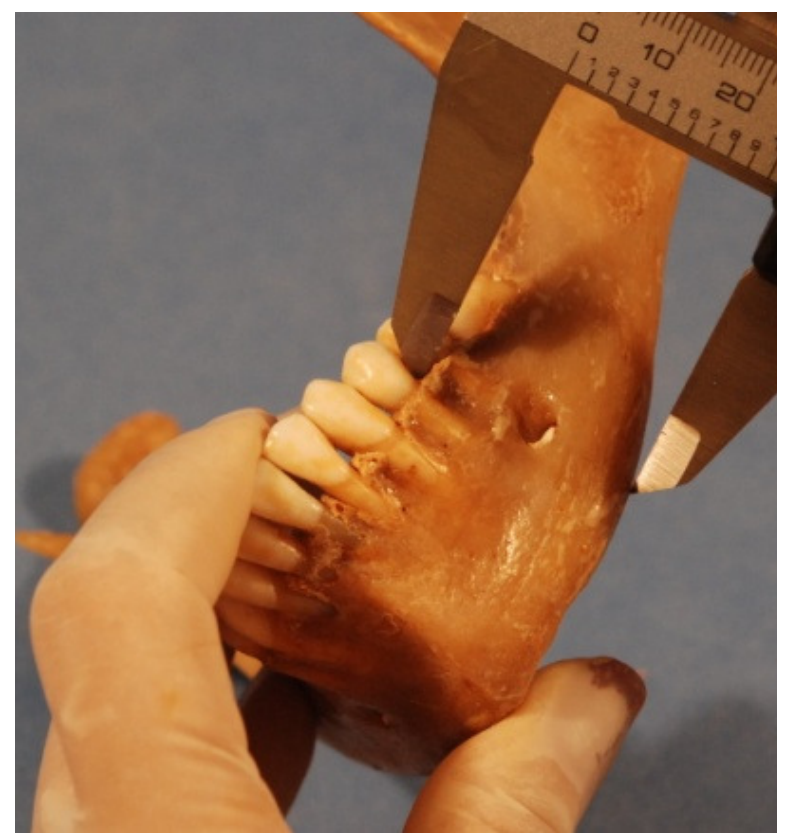


27. Body Thickness at Mental Forame (Espessura do Corpo da Mandíbula no Forame Mentoniano): Espessura na mandíbula na altura do forame mentoniano.

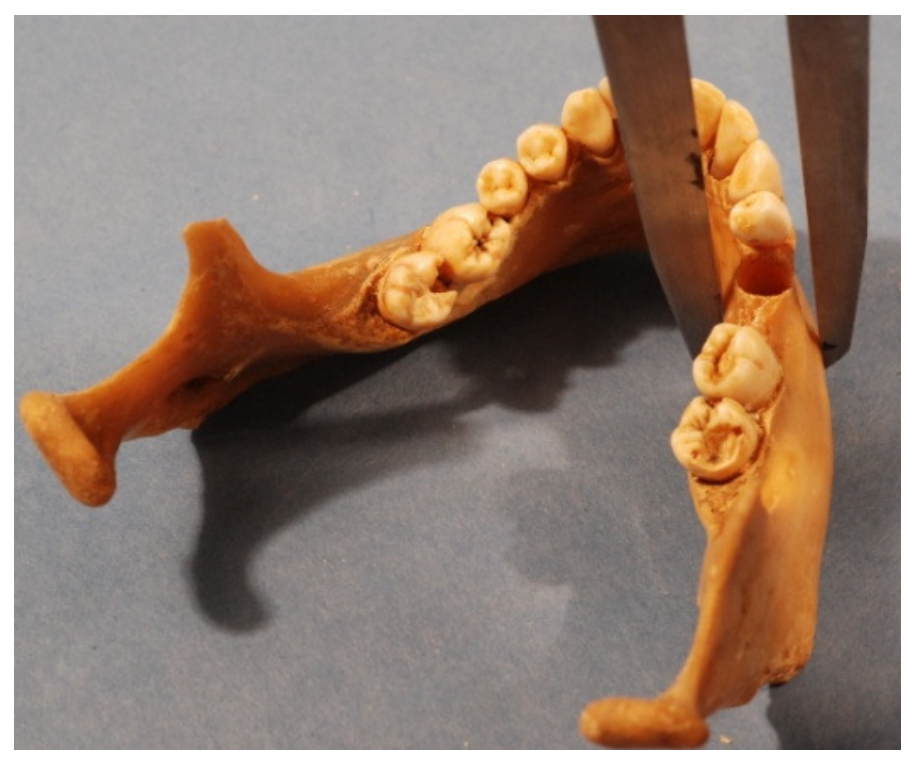

28. Bigonial Diameter (Diametro Bigonial) (go-go): Distância de um ponto Gônio ao ponto simétrico do lado oposto. Ponto Gônio: ponto do ângulo da mandíbula que mais se projeta para baixo, para trás e para fora, sendo facilmente identificável pela palpação. Ponto de encontro da bissetriz formada pelo plano mandibular com uma tangente ao bordo posterior do ramo.

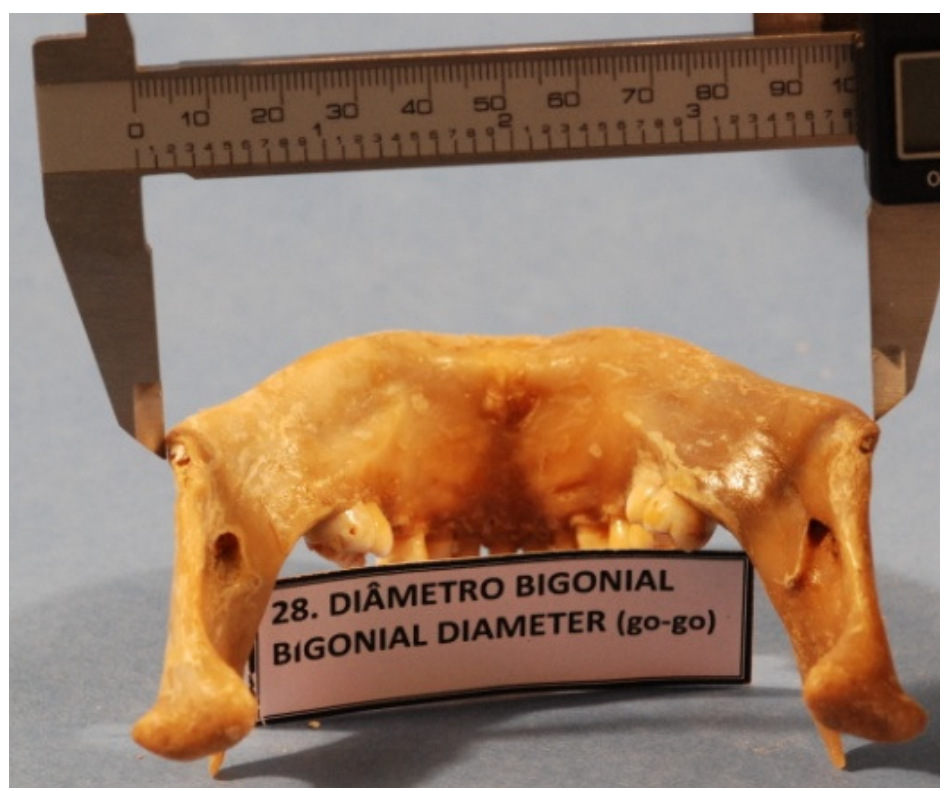


29. Bicondylar Breadth (Largura Bicondilar) (cdl-cdl): Largura entre os côndilos mandibulares.

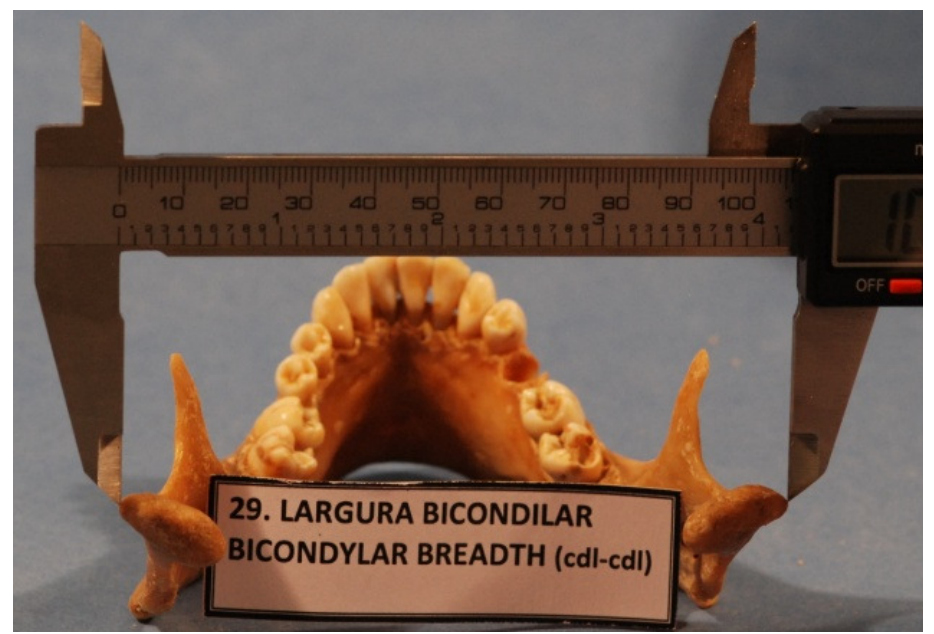

30. Minimum Ramus Breadth (Largura Mínima do Ramo Mandibular): Menor distância entre o bordo posterior e o bordo anterior do ramo mandibular, medida perpendicularmente à altura.

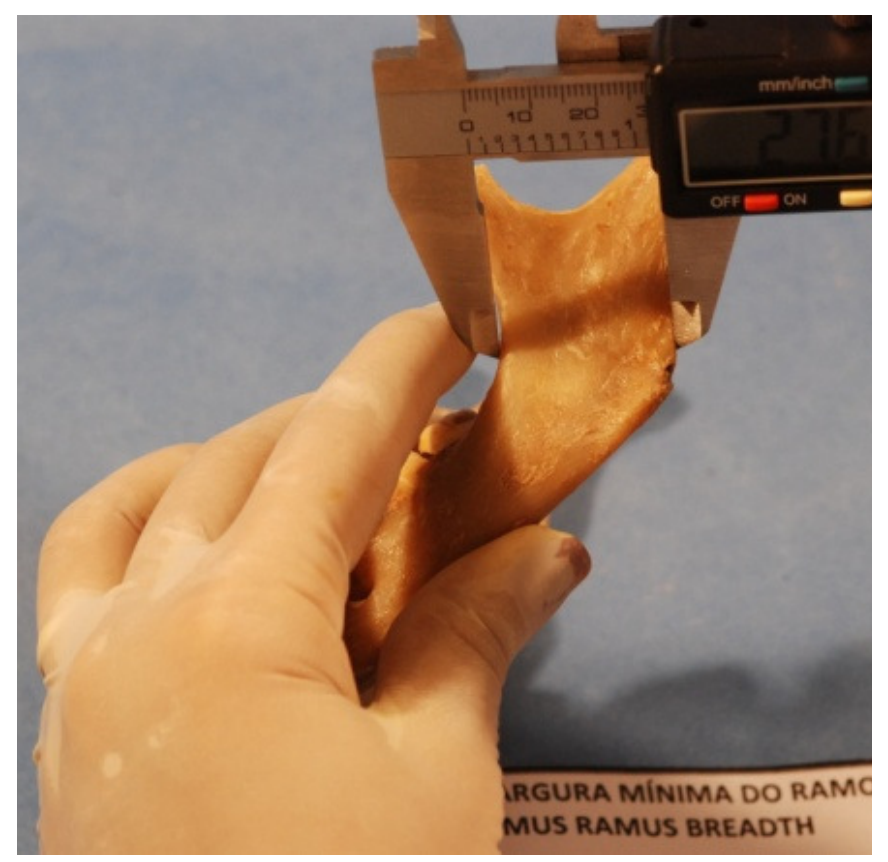


31. Maximum Ramus Breadth (Máxima Largura do Ramo Mandibular): Maior distância entre o bordo posterior e o bordo anterior do ramo mandibular, medida perpendicularmente à altura.

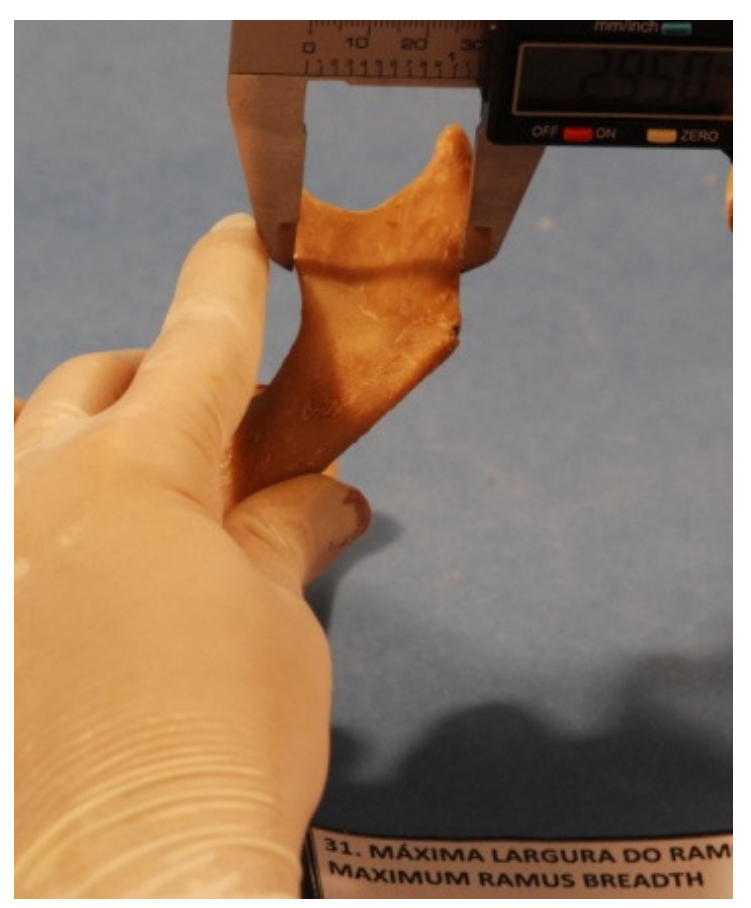

32. Maximum Ramus Heigth (Máxima Altura do Ramo Mandibular): é tomada apoiando-se os côndilos na placa horizontal, com o bordo posterior do ramo da mandíbula encostado na placa vertical. Com auxílio de uma ponteira, metálica tangenciando a borda inferior do corpo da mandíbula, executamos a leitura desta medida.

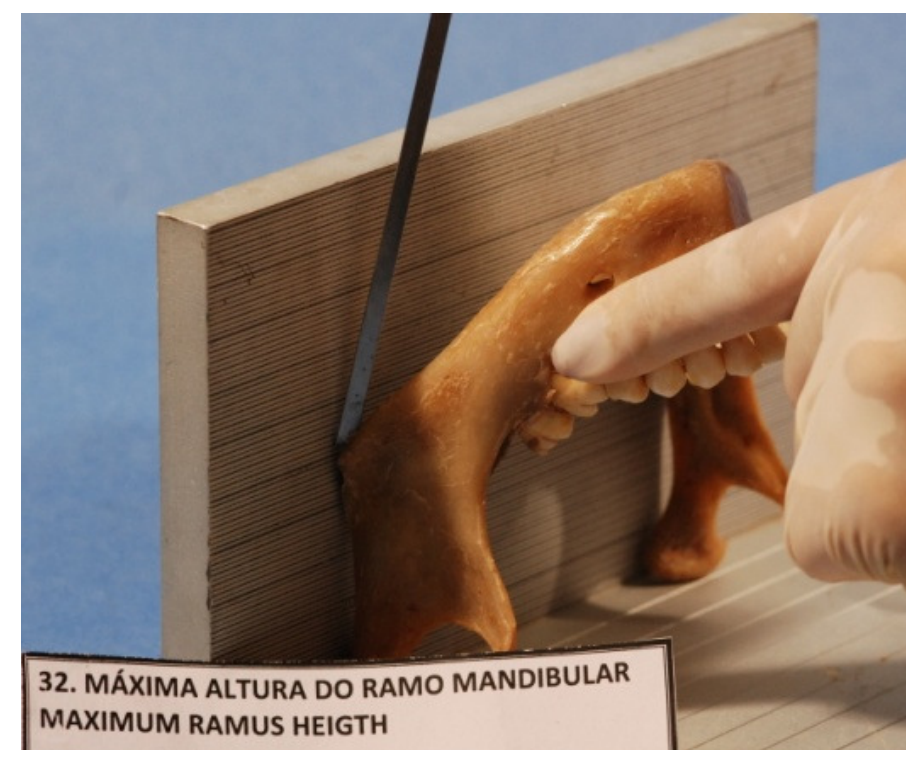


33. Mandibular Length (Comprimento Mandibular): é tomada colocando-a sobre a placa horizontal do mandibulômetro, com os côndilos apoiados na placa vertical, e a borda inferior da mandíbula apoiada na placa horizontal. A leitura é feita diretamente na placa horizontal, ao nível da linha que tangência a parte mais saliente da protuberância mentoniana.

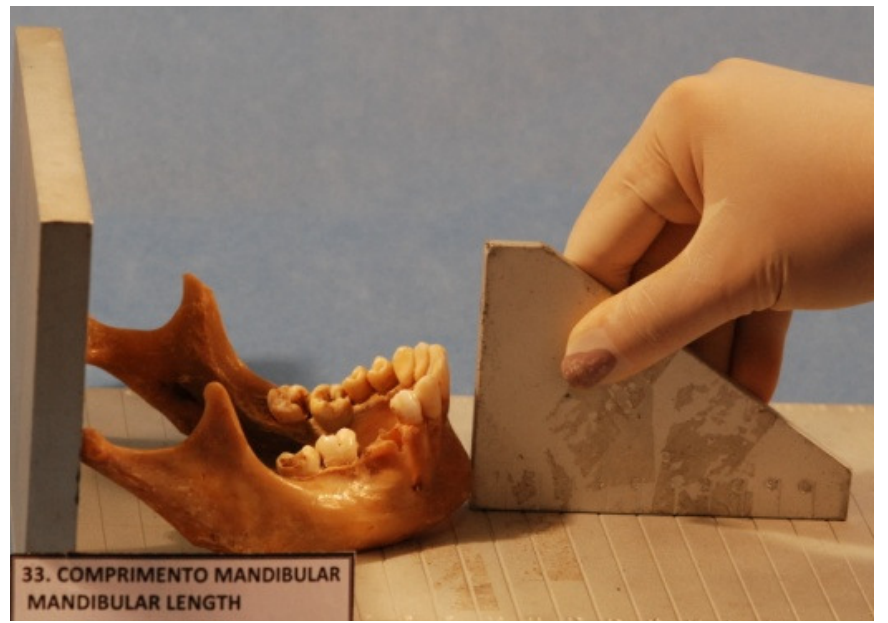

34. Mandibular Angle (Ângulo Mandibular): Tomado com a régua, passando uma tangente pelas bordas da mandíbula e depois calculando-se o ângulo com o compasso.

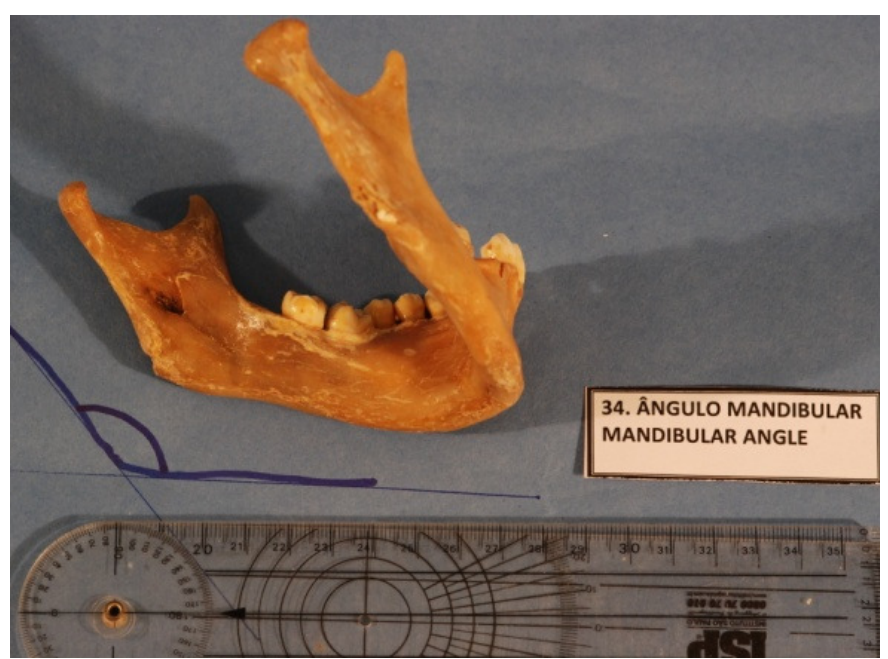


ANEXO F- Tabela de Quantificação do DNA

AMOSTRA DATA 1 QUANT 260/280 DATA 2 QUANT. 260/280 DATA 3 QUANT. 260/280 DATA 4 QUANT. 260/280 DATA 5 QUANT. 260/280 DATA 6 QUANT. 260/280 $001 / 11$ $10 / 8 \quad 59 \quad 1,87$

$002 / 11$

004 limada

$25 / 5 \quad 21,1 \quad 1,8$

$25 / 5 \quad 4,4 \quad 2,21$

004/09 $\quad 25 / 5 \quad 3,3 \quad 2,49$

$\begin{array}{llll}005 / 09 & 25 / 5 & 3,2 & 0,93\end{array}$

006/10 25/5 $\quad 8,6 \quad 4,55$

$\begin{array}{llll}007 / 10 & 25 / 5 & 9,2 & 6,47\end{array}$

$\begin{array}{llll}008 / 10 & & & \\ 009 / 10 & 25 / 5 & 74,2 & 1,99\end{array}$

$\begin{array}{llll}009 / 10 & 25 / 5 & 74,2 & 1,99 \\ 10 / 10 & 25 / 5 & 12,9 & 1,59\end{array}$

$\begin{array}{rrrr}10 / 10 & 25 / 5 & 12,9 & 1,59 \\ 11 / 10 & 25 / 5 & 8,9 & 5,09\end{array}$

$\begin{array}{llll}12 / 10 & 25 / 5 & 31,2 & 1,96\end{array}$

$\begin{array}{llll}13 / 10 & 25 / 5 & 79,7 & 1,81\end{array}$

$\begin{array}{llll}14 / 10 & 25 / 5 & 31,9 & 1,97\end{array}$

$15 / 10 \quad 25 / 5 \quad 45 \quad 1,98$

$\begin{array}{llll}16 / 10 & 25 / 5 & 29 & 2,08\end{array}$

$\begin{array}{llll}017 / 10 & & & \\ 018 / 10 & 25 / 5 & 9,1 & 4,4\end{array}$

$\begin{array}{llll}019 / 10 & 25 / 5 & 19,8 & 2,24\end{array}$

020/10 25/5 $\quad 47,2 \quad 2,06$

020/10 Dente $\quad 25 / 5 \quad 10,6 \quad 3,92$

$021 / 10 \quad 25 / 5 \quad 9,7 \quad 5,14$

$\begin{array}{llll}022 / 10 & 25 / 5 & 10 & 4,14\end{array}$

023/10 25/5 $25,1 \quad 1,82$

$024 / 10 \quad 25 / 5 \quad 8,3 \quad 4,18$

$\begin{array}{llll}025 / 10 & 25 / 5 & 9,6 & 3,64\end{array}$

$\begin{array}{llll}026 / 10 & 25 / 5 & 13,7 & 2,84\end{array}$

$\begin{array}{llll}027 / 10 & 25 / 5 & 22,8 & 2,39\end{array}$

$\begin{array}{llll}028 / 10 & 25 / 5 & 43,2 & 1,88\end{array}$

$\begin{array}{llll}029 / 10 & 25 / 5 & 17,7 & 2,38\end{array}$

$030 / 10 \quad 25 / 5 \quad 19,7 \quad 1,66$

$\begin{array}{llll}031 / 10 & & & \\ 032 / 10 & 25 / 5 & 12,3 & 2,94\end{array}$

$\begin{array}{llll}032 / 10 & 25 / 5 & 12,3 & 2,94 \\ 033 / 10 & 25 / 5 & 11,3 & 3,06\end{array}$

$034 / 10$

$035 / 10$

$036 / 10$

$037 / 10$

$038 / 10$

$039 / 10$

$040 / 10$

$041 / 10$

$042 / 10$

$043 / 11$

$044 / 11$

$045 / 11$

$046 / 11$

$046 / 11$

$047 / 11$

$048 / 11$

$049 / 11$

$050 / 11$

$051 / 11$

052/11

$053 / 11$

054/11

$055 / 11$

056/11

$057 / 11$

$058 / 11$

$059 / 11$

060/11

$061 / 11$

062/11

$063 / 11$

064/11

$065 / 11$

$10 / 8 \quad 31,8 \quad 2,18$

$10 / 8 \quad 74,8 \quad 2,11$

$10 / 8 \quad 52,6 \quad 1,94$

$10 / 8 \quad 27,7$

$10 / 8 \quad 15,2 \quad 1,84$

$\begin{array}{lll}25 / 5 & 9 & 3,87\end{array}$

$25 / 5 \quad 11 \quad 3,34$

$25 / 5 \quad 18,6 \quad 2,25$

$25 / 5 \quad 14,1 \quad 2,35$

$\begin{array}{lll}25 / 5 & 9,2 & 8,1\end{array}$

$25 / 5 \quad 176,9 \quad 1,87$

$25 / 5 \quad 10 \quad 9,06$

$25 / 5 \quad 10,3 \quad 3,6$

$25 / 5 \quad 9,3 \quad 9,97$

$25 / 5 \quad 10 \quad 4,54$

$25 / 5 \quad 10 \quad 4,47$

$25 / 5 \quad 33,1 \quad 0,64$

$25 / 5 \quad 9,8 \quad 10,12$

$25 / 5 \quad 9,8 \quad 4,66$

$\begin{array}{rrrrrrrrr} & & & 6 / 9 & 28,9 & 2,96 & 9 / 9 & 19,5 & 4,09 \\ 31 / 8 & 25 & 3,43 & & & & 9 / 9 & 14,3 & 4,03 \\ 31 / 8 & 24,4 & 3,48 & & & & 9 / 9 & 18,8 & 3,12 \\ 31 / 8 & 23,6 & 3,28 & & & & 9 / 9 & 49,1 & 1,91 \\ & & & & & & & & \\ & & & & & & & & \\ 31 / 8 & 40,2 & 3,26 & & & & 9 / 9 & 20,1 & 3,01 \\ 31 / 8 & 19 & 3,59 & & & & 9 / 9 & 25 & 1,15\end{array}$

$31 / 8$

$\begin{array}{rrrrrr}6 / 9 & 28,8 & 3,07 & 9 / 9 & 21,7 & 3,36 \\ 6 / 9 & 21 & 2,67 & 9 / 9 & 42,2 & 2,04 \\ & & & & & \\ & & & 9 / 9 & 45,9 & 2,39 \\ & & & 9 / 9 & 27,4 & 3,62 \\ & & & 9 / 9 & 17,7 & 4,63\end{array}$

$6 / 9 \quad 35,8 \quad 2,26$

$\begin{array}{lll}31 / 8 & 17,6 & 2,86 \\ 31 / 8 & 44,7 & 2,27\end{array}$

$\begin{array}{rrr}31 / 8 & 44,7 & 2,27 \\ 31 / 8 & 29 & 3,51\end{array}$

$9 / 9 \quad 23,6 \quad 3,97$

$31 / 8 \quad 21,4 \quad 3,36$

$6 / 9 \quad 20,4 \quad 2,86$

$\begin{array}{lll}9 / 9 & 22,9 & 2,84\end{array}$

$31 / 8 \quad 44,1 \quad 2,79$

$31 / 8 \quad 43,2$

$\begin{array}{rrr}6 / 9 & 34,8 & 2,17 \\ 6 / 9 & 17,7 & 3,28 \\ 6 / 9 & 34,9 & 2,8 \\ 6 / 9 & 31,1 & 2,05 \\ 6 / 9 & 42 & 2,45 \\ 6 / 9 & 21,9 & 2,94\end{array}$

$\begin{array}{rrr}24 / 8 & 32 & 2,73 \\ 24 / 8 & 22,1 & 2,56\end{array}$

$\begin{array}{lll}24 / 8 & 33 & 2,53\end{array}$

$6 / 9 \quad 11,5 \quad 2,26$

$\begin{array}{lll}6 / 9 & 14,7 & 3,37\end{array}$

$6 / 9 \quad 18,6 \quad 3,53$

$6 / 9 \quad 15,3 \quad 3,39$

$6 / 9 \quad 20,4 \quad 2,64$

$6 / 9 \quad 19,1 \quad 3,01$

$6 / 9 \quad 27,1 \quad 3,69$

$\begin{array}{llllll}11 / 8 & 85,3 & 1,86 & & & \\ 11 / 8 & 46,6 & 1,97 & 24 / 8 & 20,7 & 2,84\end{array}$

$11 / 8 \quad 52,1 \quad 2,01$

$11 / 8 \quad 22,5 \quad 2,03$

$11 / 8 \quad 41,8 \quad 1,91$

$\begin{array}{rrrrrr} & & & 24 / 8 & 26,6 & 2,07 \\ & & & 24 / 8 & 20,2 & 2,13 \\ 11 / 8 & 18,1 & 2,1 & 24 / 8 & 15,2 & 0,09 \\ 11 / 8 & 44,2 & 1,76 & & & \\ & & & 24 / 8 & 45,6 & 2,02 \\ 11 / 8 & 40,9 & 1,76 & & & \\ & & & 24 / 8 & 31,6 & 2,35 \\ & & & 24 / 8 & 29,5 & 1,97 \\ & & & 24 / 8 & 52,6 & 1,96\end{array}$

$11 / 8 \quad 28,8 \quad 1,98$ 


\section{ANEXO G-Planilha com parâmetros qualitativos e quantitativos}

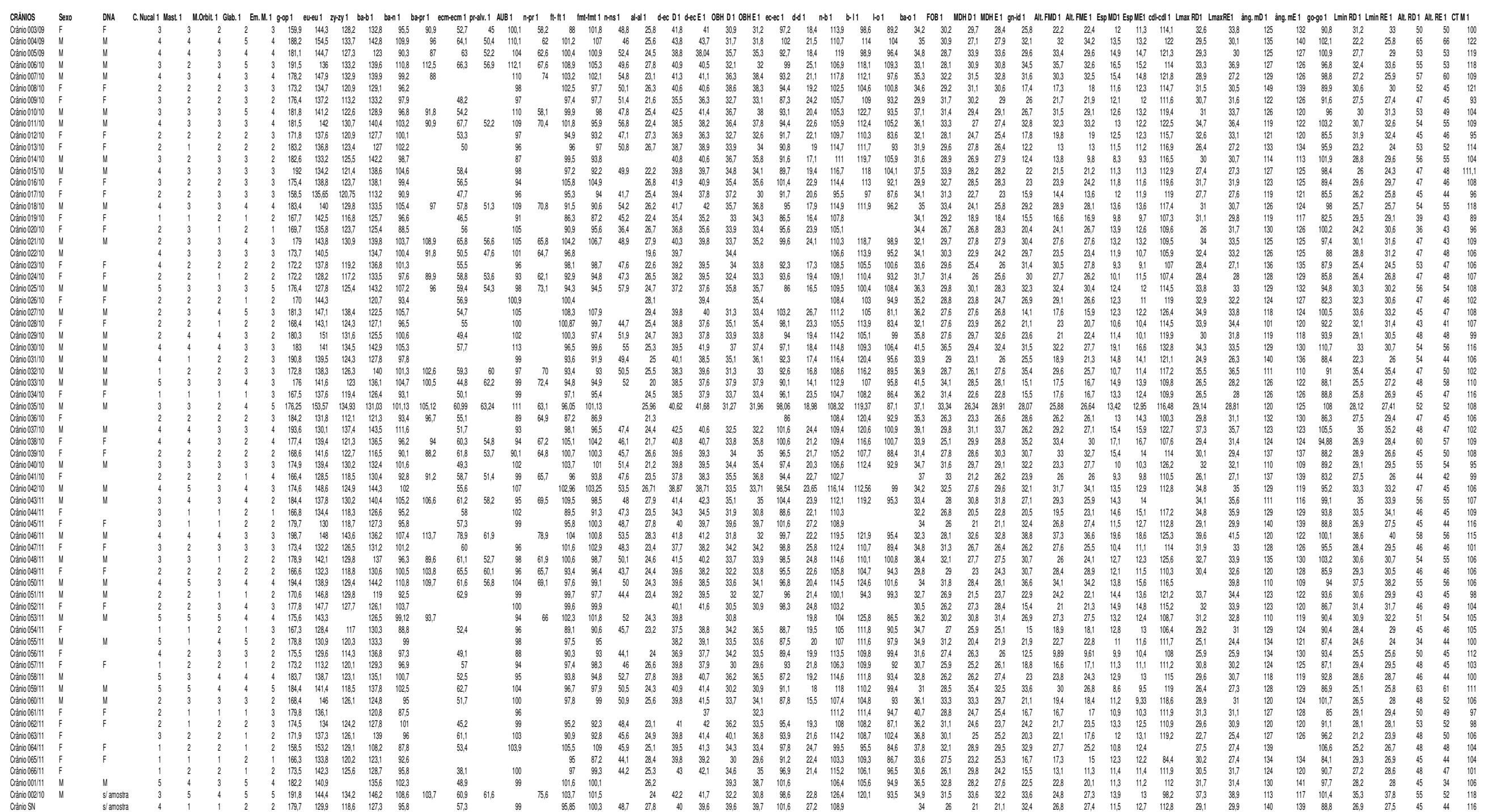


ANEXO H- Resultados da análise de fragmentos para o gene amelogenina (picos)
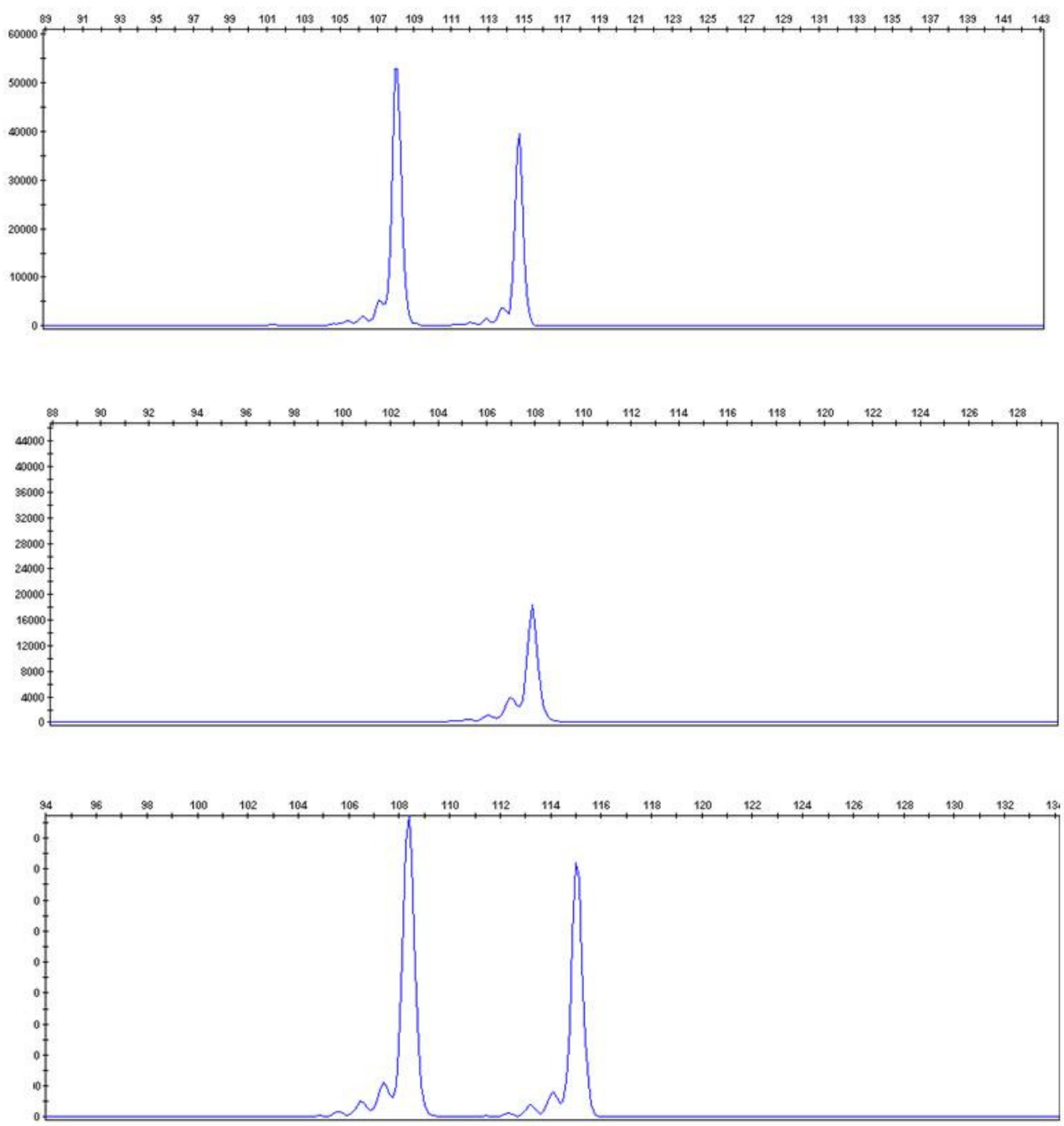

004

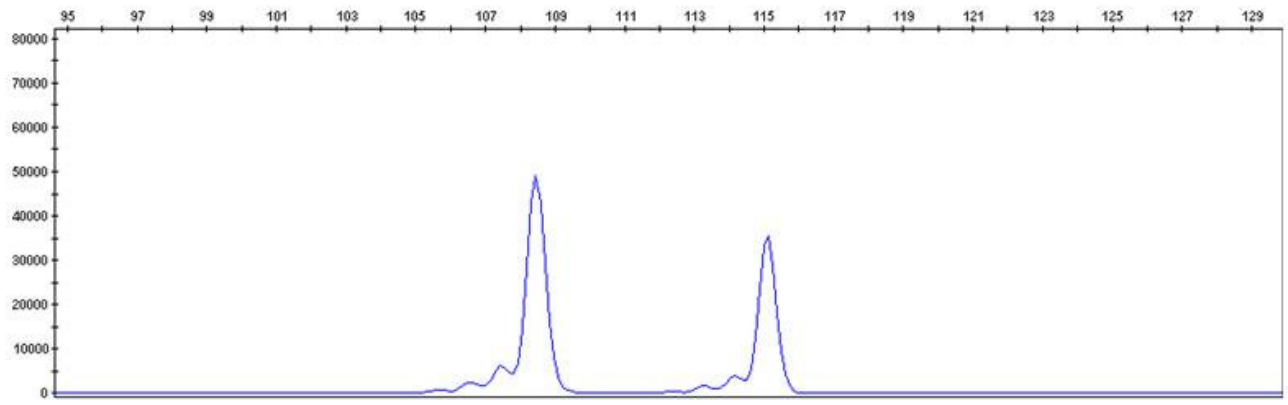



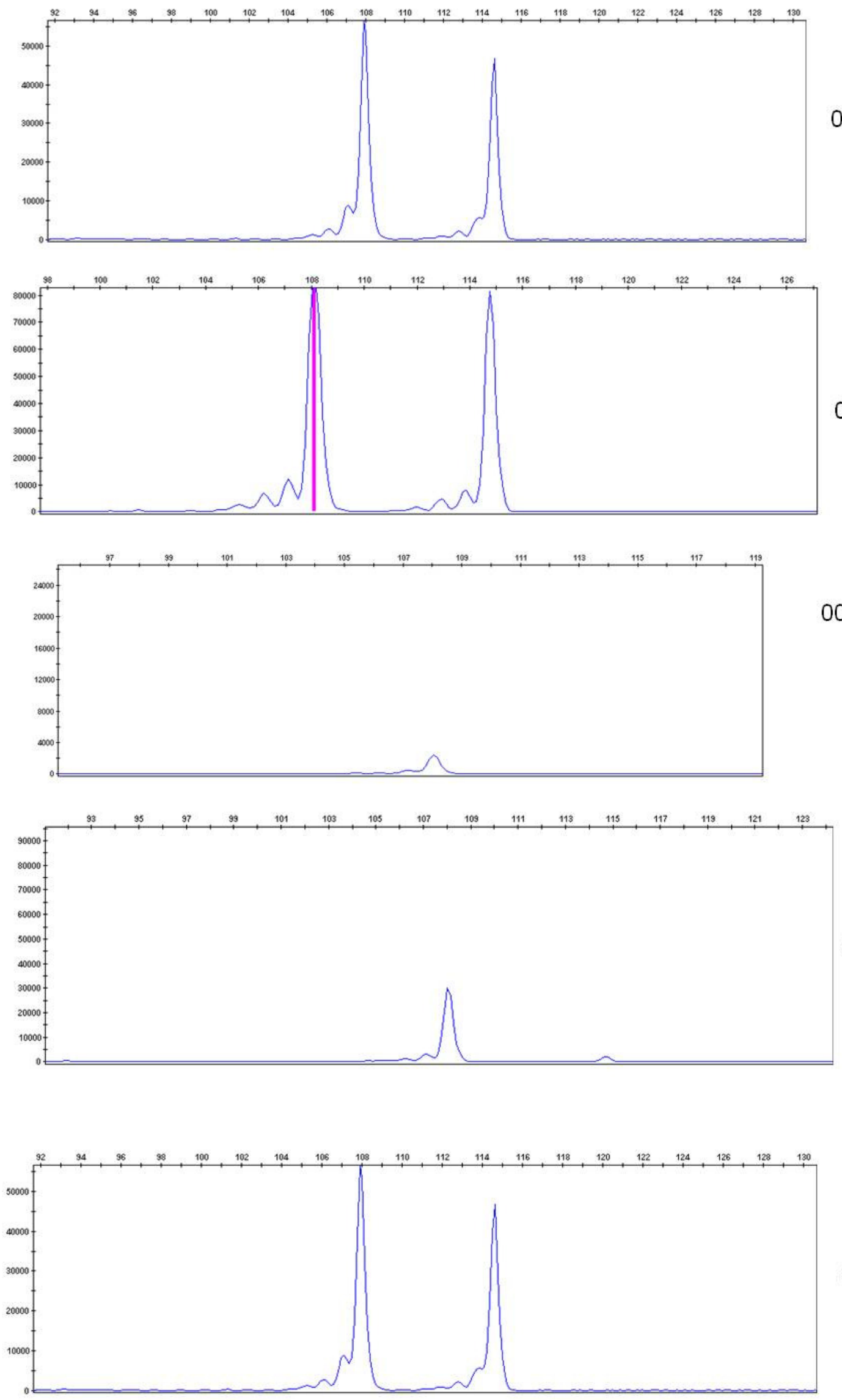

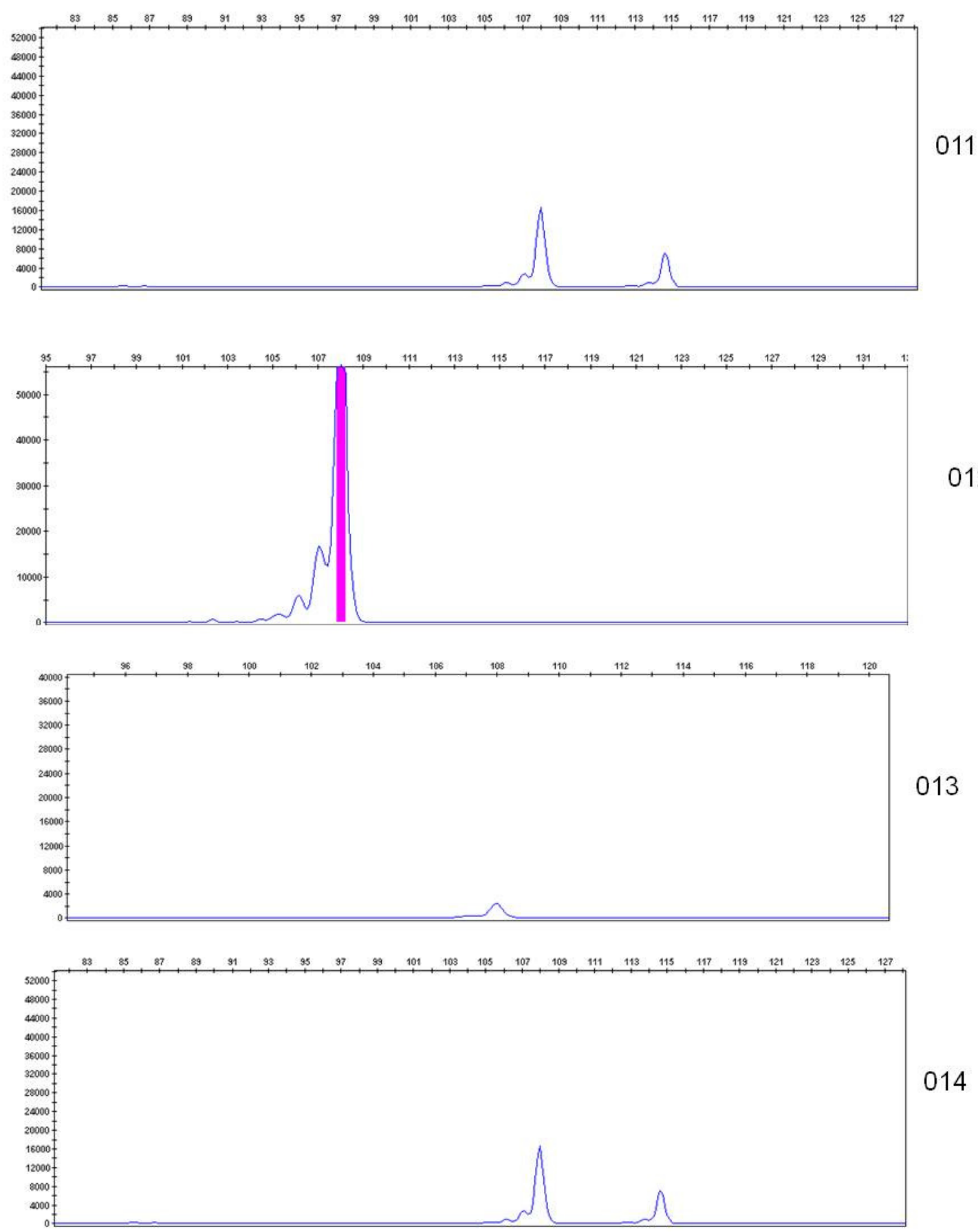

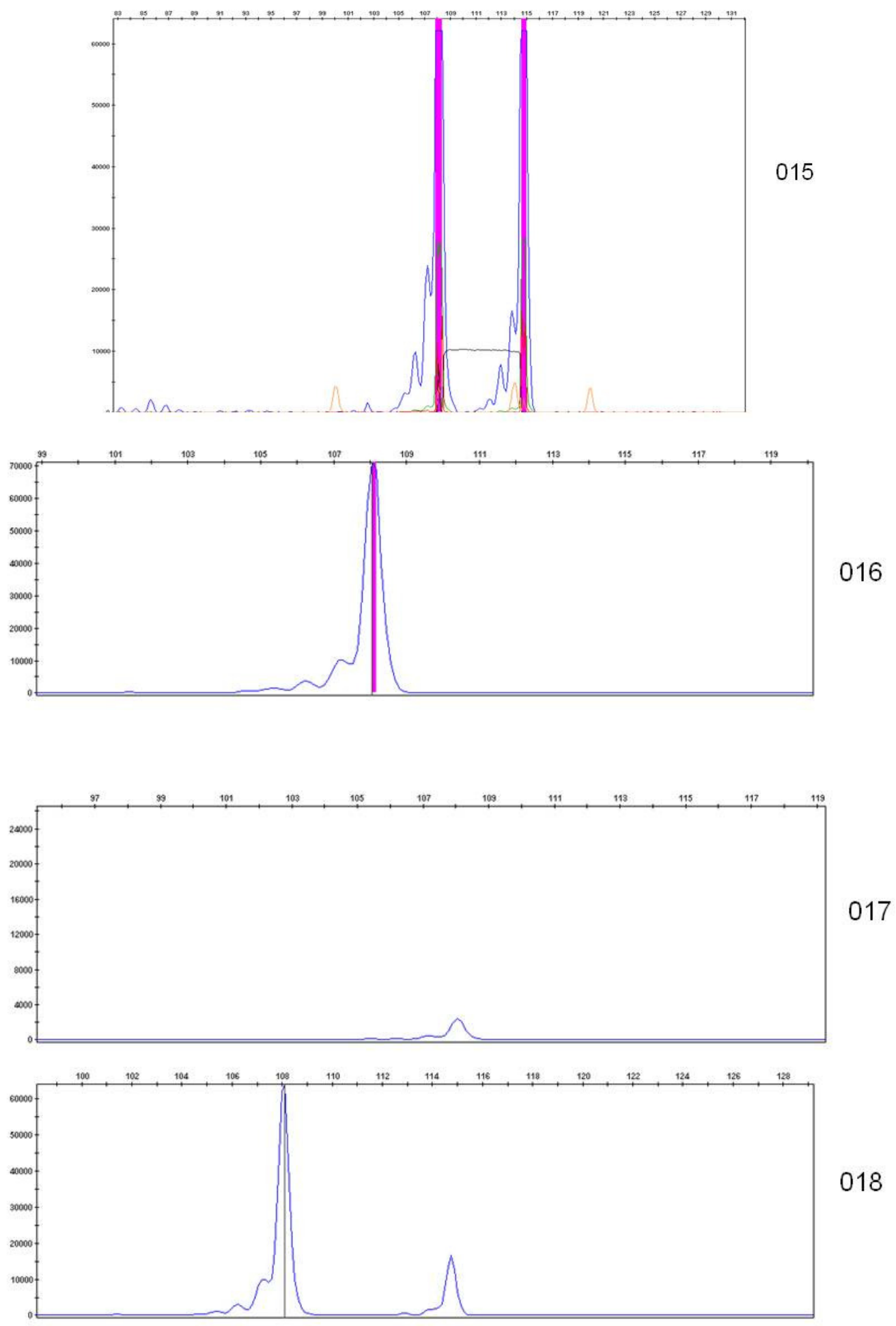

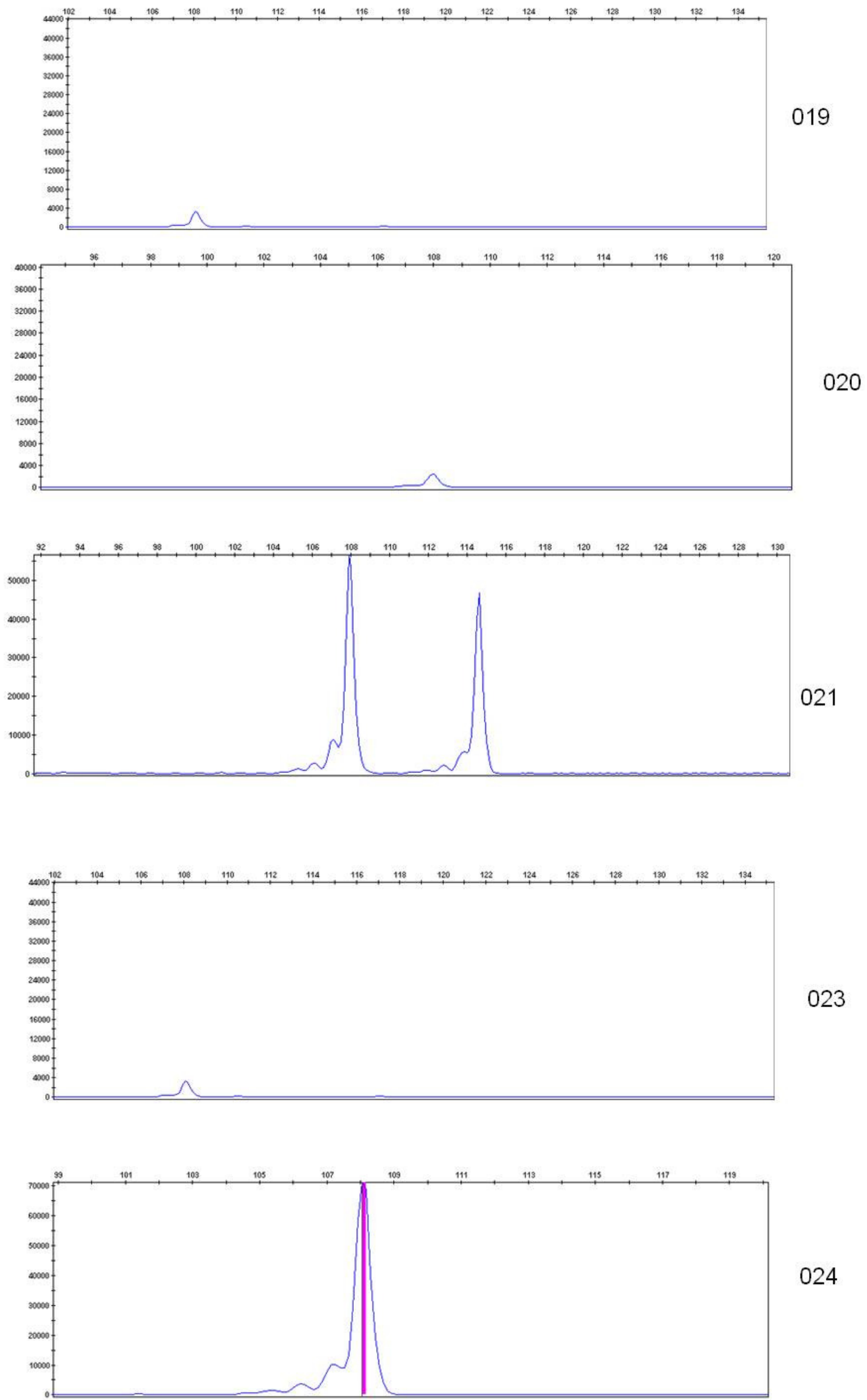

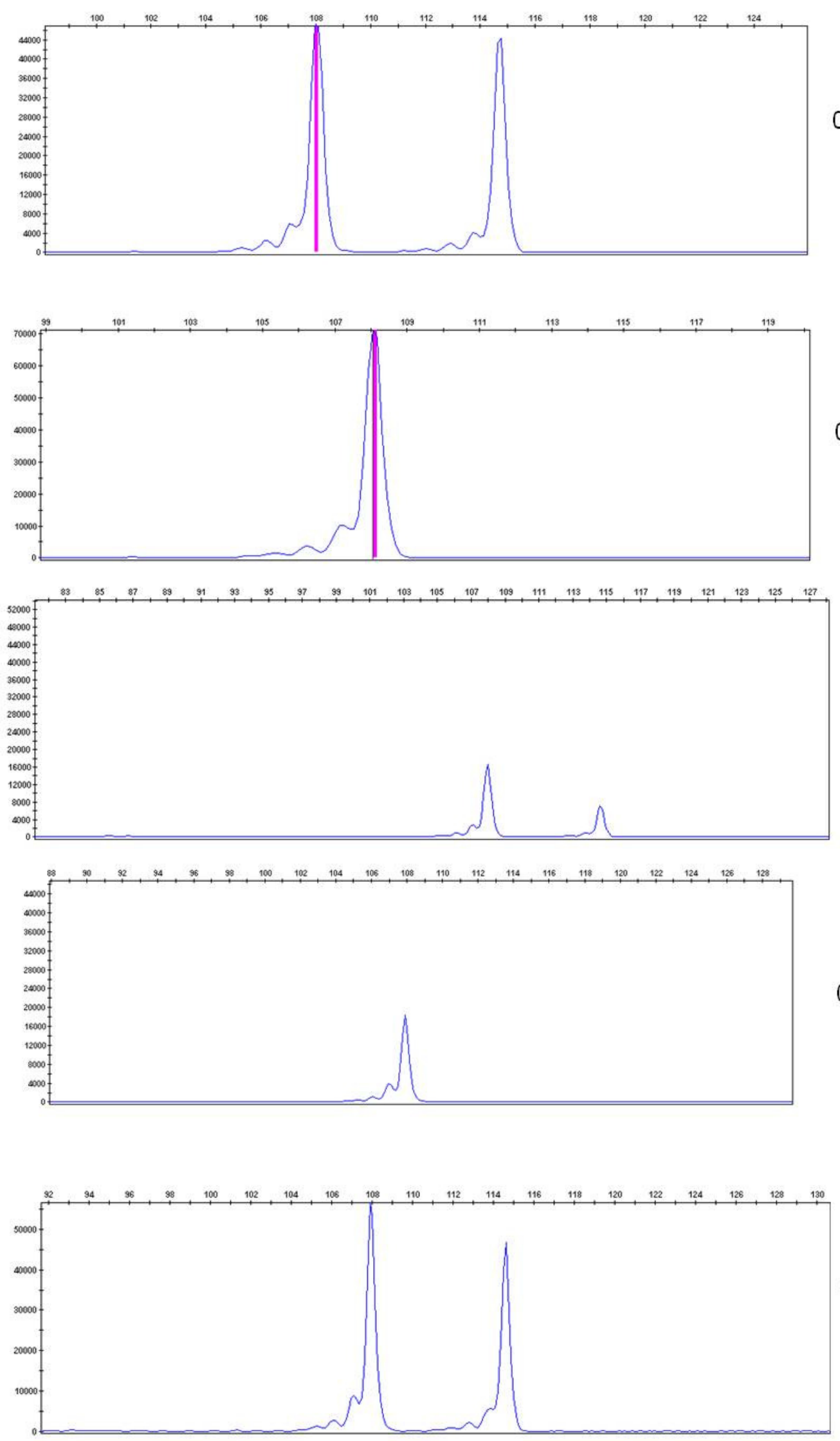

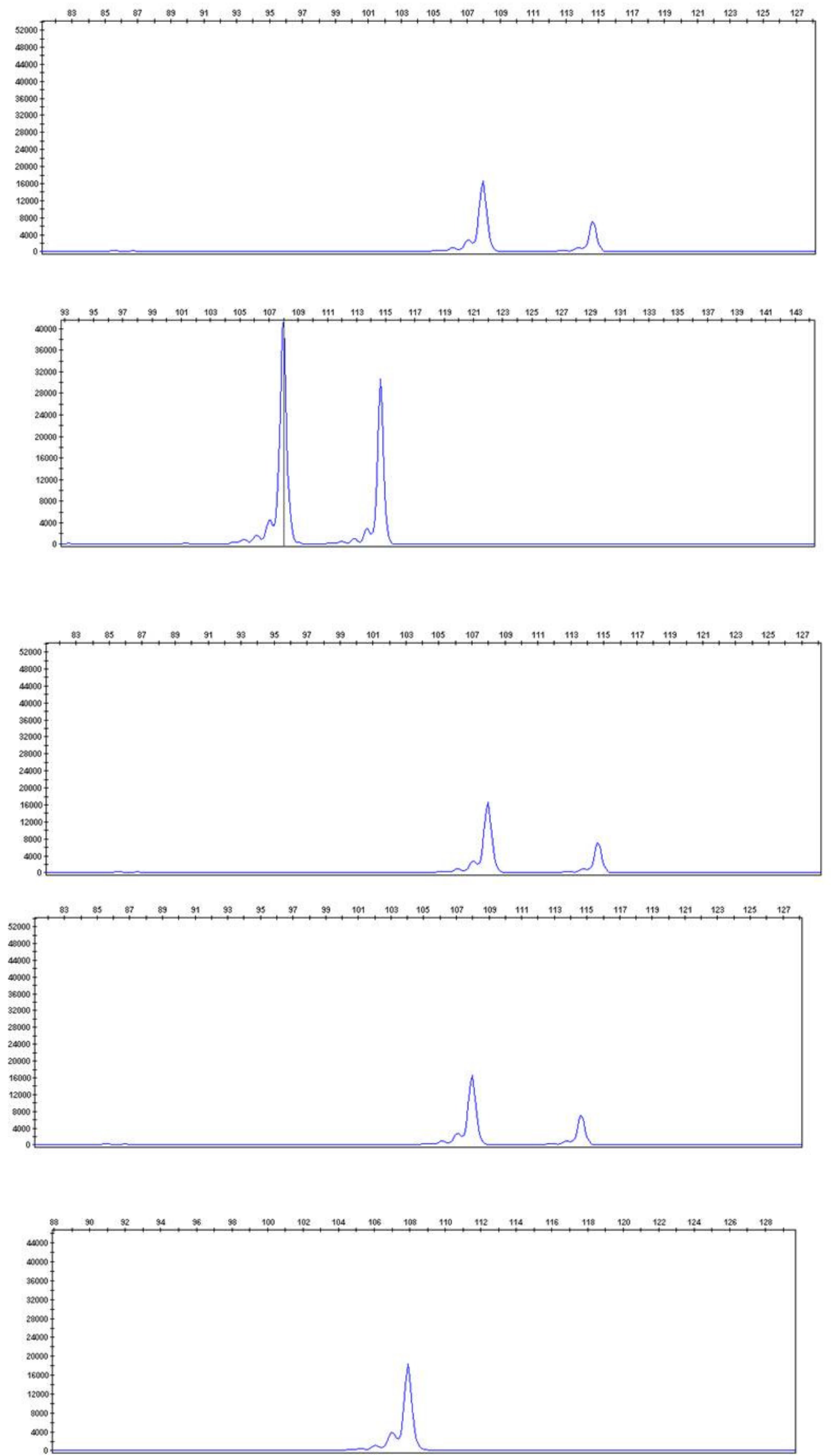

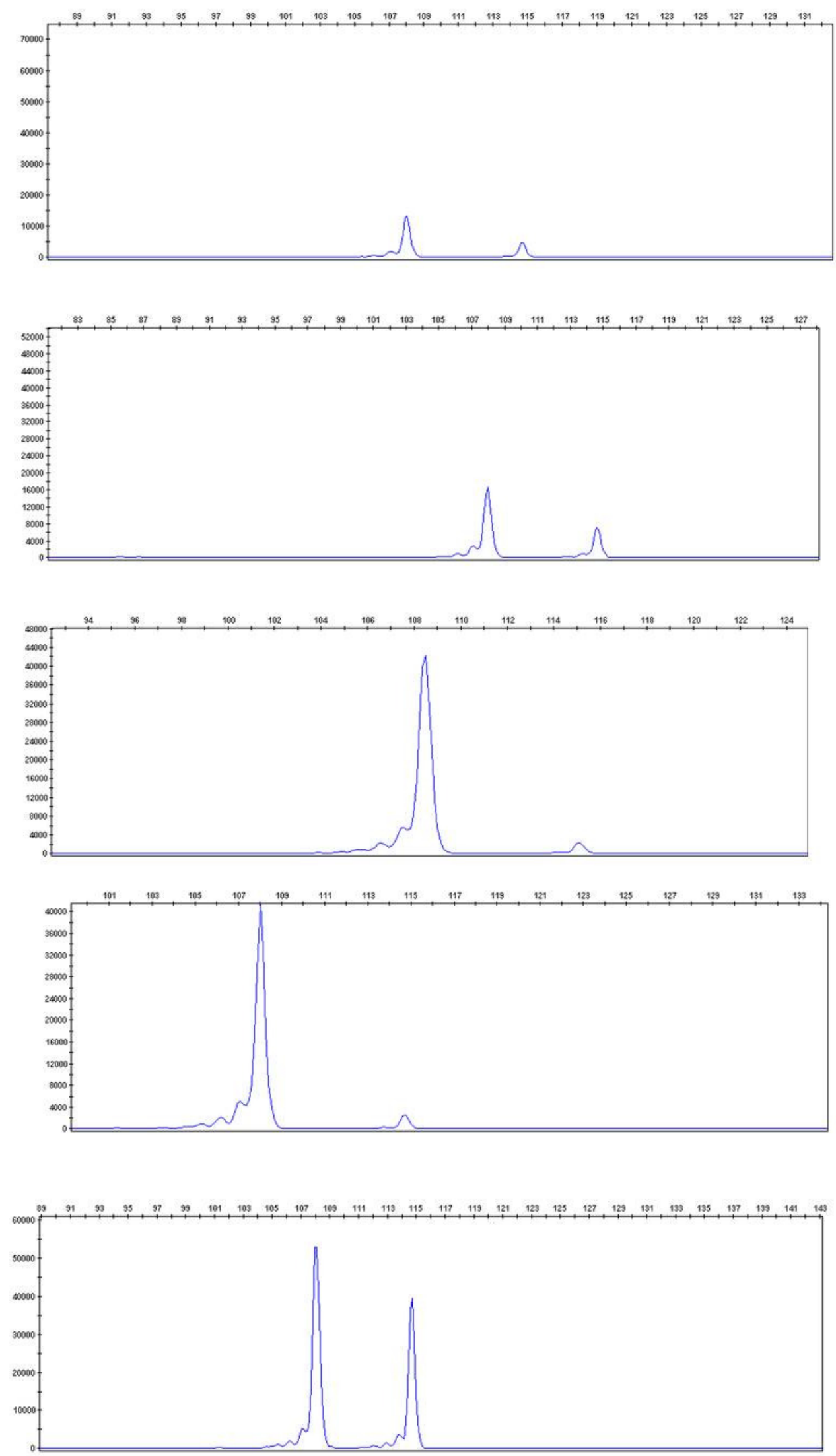

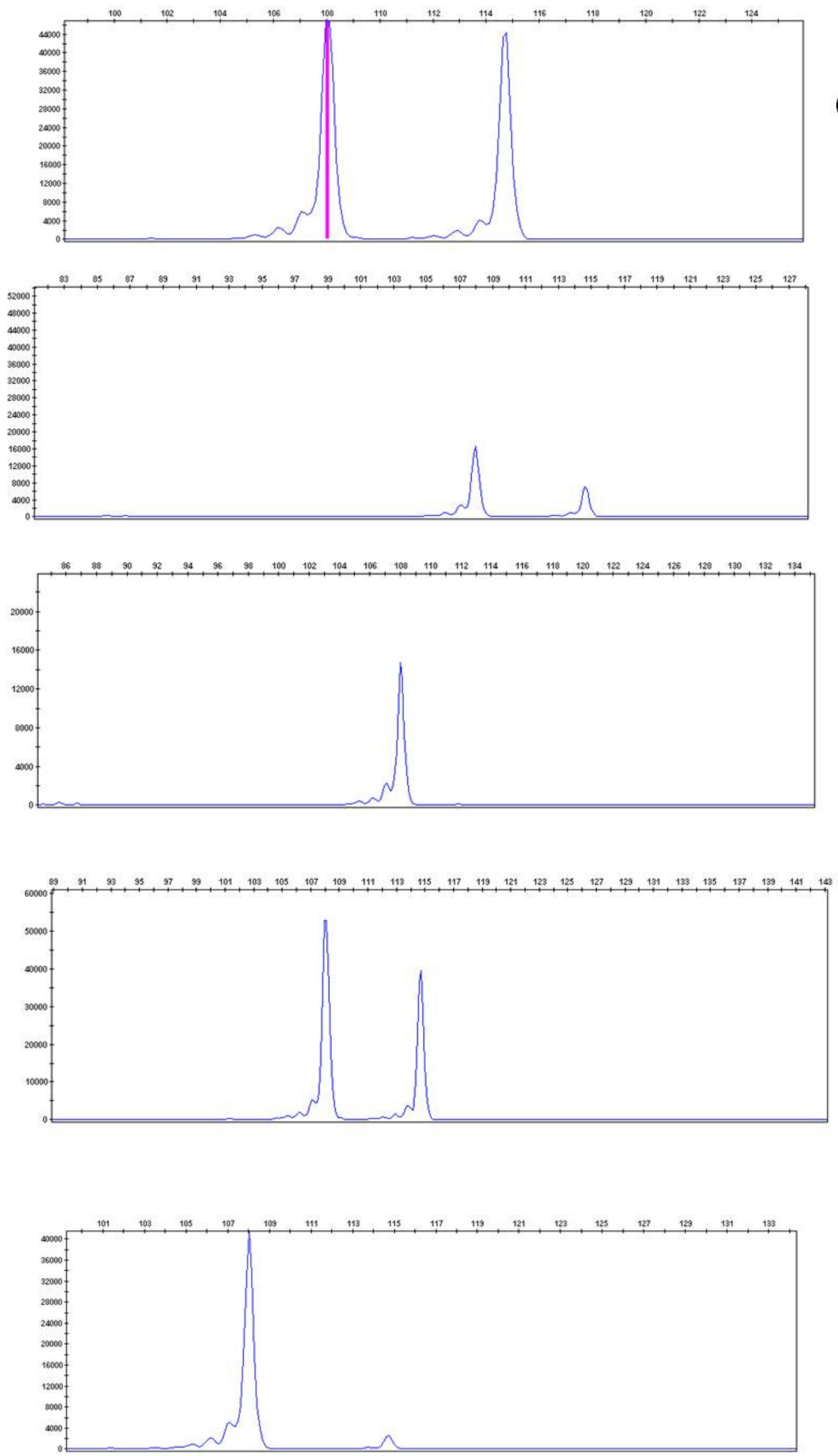

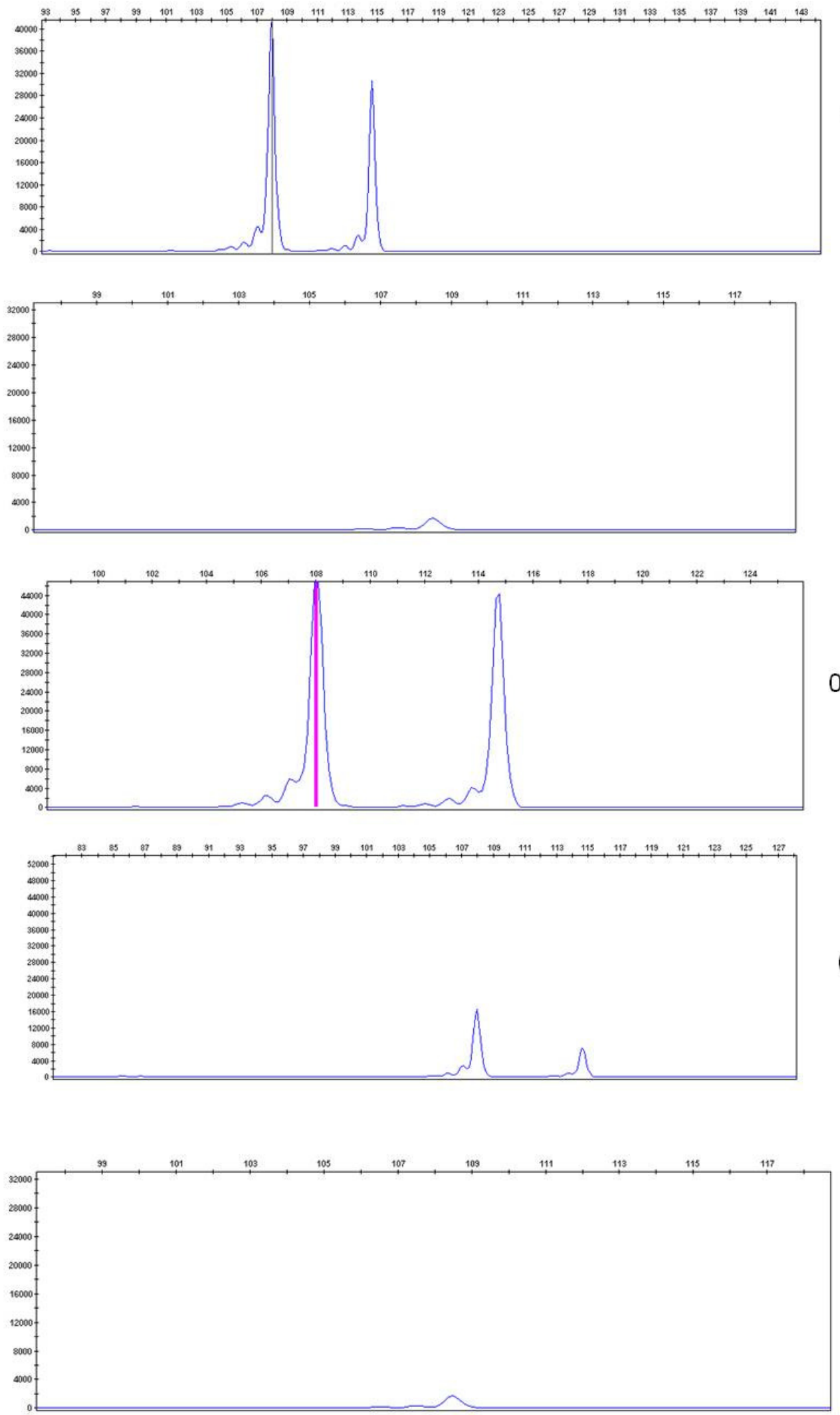

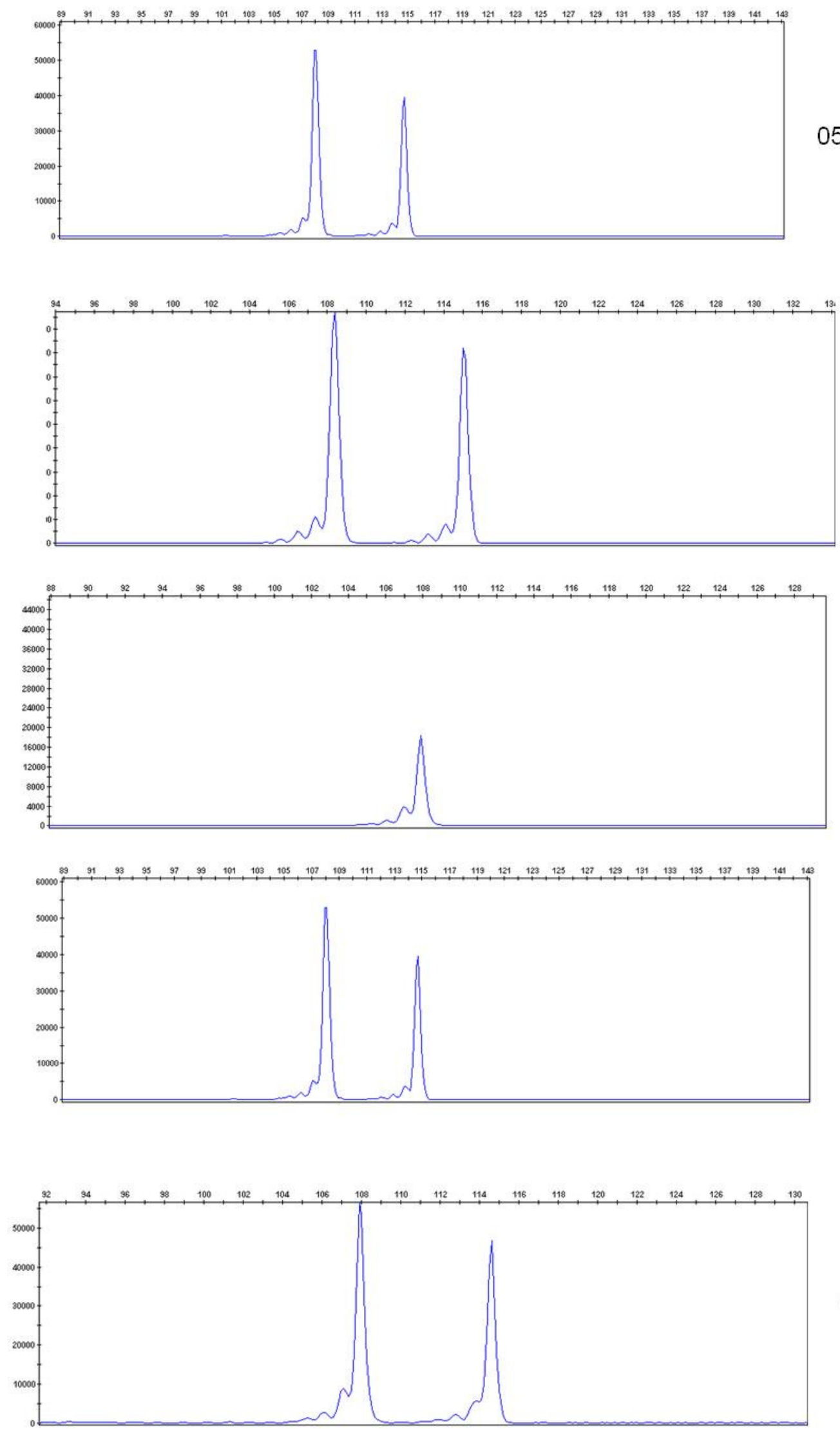


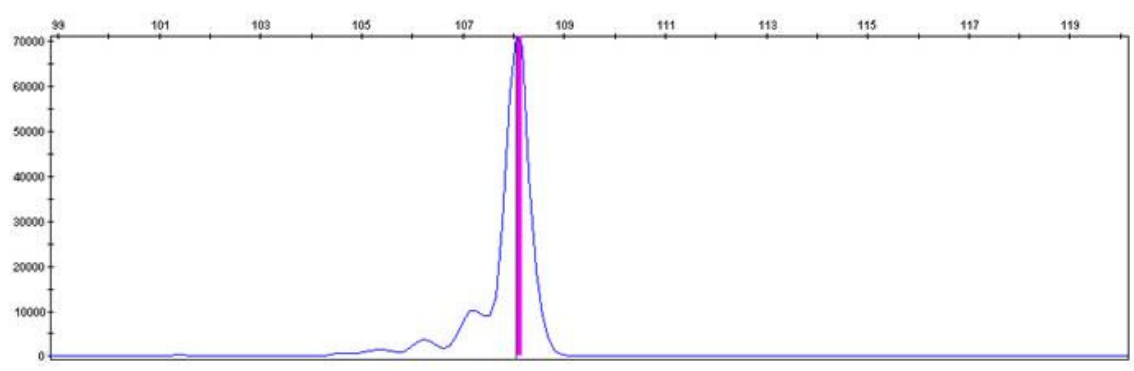

061
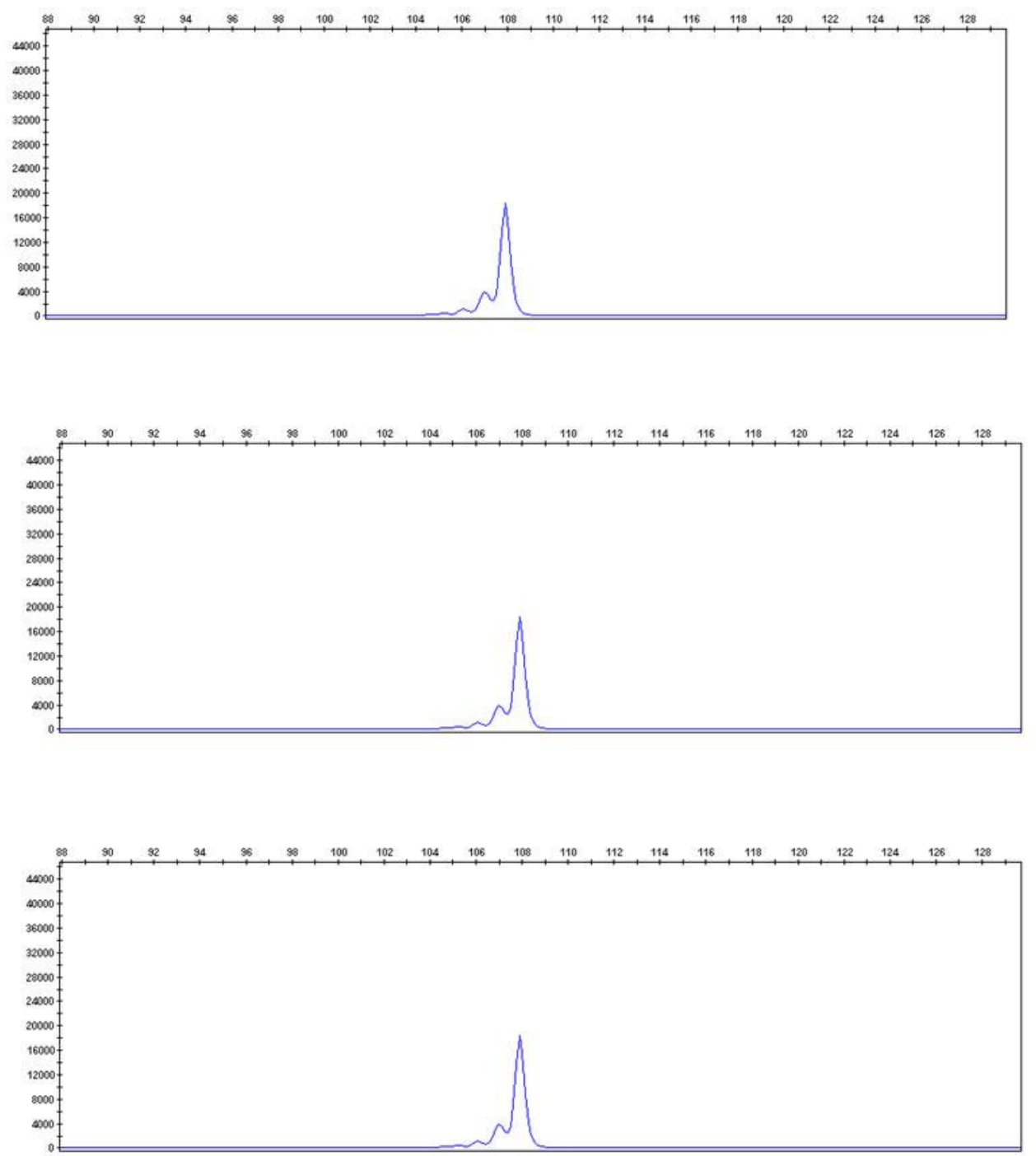